\title{
Paar sammukest XXVIII
}

Eesti Kirjandusmuuseumi

aastaraamat 2011 



\section{Paar sammukest XXVIII}

Eesti Kirjandusmuuseumi aastaraamat 2011

Tartu 2013

Eesti Kirjandusmuuseumi Teaduskirjastus 
Sarja peatoimetaja: Janika Kronberg

Toimetaja: Kadri Tüür

Kaastoimetajad: Kanni Labi, Merike Kiipus

Assistent: Maarja Villandi

Tõlked inglise keelde: Kadri Tüür

E-raamat: Andres Kuperjanov, Diana Kahre

Küljendus: Pille Niin / Unenoppija

Kujundus ja makett: Kristiina Rosina / Momo

Toimetuskolleegium:

Risto Järv (Eesti Kirjandusmuuseum)

Merike Kiipus (Eesti Kirjandusmuuseum)

Mare Kõiva (Eesti Kirjandusmuuseum)

Merja Leppälahti (Suomalaisen Kirjallisuuden Seura, Helsingi)

Aado Lintrop (Eesti Kirjandusmuuseum)

Triinu Ojamaa (Eesti Kirjandusmuuseum)

Péter Pomozi (Eötvös Lorándi Ülikool (ELTE), Budapest, Ungari)

Ilpo Saastamoinen (Suomen Kansanmusiikkiliitto, Jyväskylä)

Virve Sarapik (Eesti Kirjandusmuuseum)

Indekseeritud: MLA (Modern Language Association) Bibliography, Internationale Volkskundliche Bibliographie

http://www.kirmus.ee/Asutus/ar.php

ISSN trükiversioon 1406-5428

ISSN veebiversioon 1736-6356

(C) Eesti Kirjandusmuuseumi Teaduskirjastus

(C) Autorid 
7 Eessõna

\section{Artiklid}

12 Kunstniku Kalevipoeg: eepose ja müüdi taasesitus Kristjan Rauast Gunnar Neemeni

Kärt Summatavet

47 Gnoomid, kooboldid ja goblinid.

Uskumusolendite nimetuste tõlkimise spetsiifikast Reet Hiiemäe

72 Mõningaid võrdlusmomente Kesk-Assüüria ja Uus-Assüüria raidkirjadest, kroonikatest ja annaalidest 1500-612 eKr ning nende tekstide tõlkimisega seotud probleemid Vladimir Sazonov

103 Grammatiline sugu - tõlkija sõber või vaenlane? Sirje Kupp-Sazonov

127 Tänapäeva vadja keel - kõnes ja kirjas Heinike Heinsoo

151 Vepsakeelsest kirjandusest Enn Ernits

\section{Esseed, ülevaated}

176 Tõlke vältimatusest Toomas Kiho 
185 Kogumisaktsiooni "Looduslike liikide söömine lapsepõlves 2011" eellugu ja aruanne

Raivo Kalle, Renata Sõukand

194 KIVIKE - Kirjandusmuuseumi virtuaalne kelder Kadri Tü̈r

\section{1. aasta kroonika}

202 Eesti Kirjandusmuuseum 2011. aastal Janika Kronberg

206 Eesti kirjandusmuuseumi sündmuste kroonika 2011 Krista Ojasaar, Kadri Tü̈̈r, Moon Meier

214 Arhiivraamatukogu Merike Kiipus

229 Eesti Kultuurilooline Arhiiv Vilve Asmer

254 Eesti Rahvaluule Arhiiv Risto Järv, Mari Sarv

282 Etnomusikoloogia osakond Triinu Ojamaa

288 Folkloristika osakond Mare Kõiva

323 Eesti Kirjandusmuuseumi väljaanded 2011 Merike Kiipus 


\section{Eessõna}

Head aastaraamatu lugejad!

Teie ette jõuab Eesti Kirjandusmuuseumi XXVIII aastaraamat. Väljakujunenud formaati järgides koosneb see kolmest osast.

Esmalt pakume lugemiseks teadusartikleid, mis on valminud 2011. aasta Kreutzwaldi päevadel kõlanud ettekannete põhjal. Kirjandusmuuseumi traditsioonilise aastalõpukonverentsi teemaks oli "Tôlge kultuuris". Juri Lotman on osutanud, et kultuuri toimimiseks vajaliku dialoogi tagamiseks peab selles kasutama vähemalt kaht mitte täielikult kattuvat keelt. Uut teadmist loob teisest (keelest) arusaamiseks tehtav pingutus. "Keelt" ei mõisteta siinjuures ainult lingvistilises mõttes, vaid märgisüsteemina üldisemalt. Kultuuri vältimatu mitmekeelsuse üle mõeldes on iga autor üldteemale lähenenud oma uurimisteemast või materjalist lähtuvalt. Artiklite teemad ulatuvad muistsete kuningate valitsemisviisidest uskumusolenditeni, kujutavast kunstist keeleteaduseni.

Kogumiku esimene artikkel kunstnik Kärt Summatavetilt paigutab tõlketeema konteksti, mis 2011. aastal oli kirjandusmuuseumi jaoks erilise tähendusega. Tähistamaks 150 aasta möödumist "Kalevipoja" esmatrükist andis Eesti Kirjandusmuuseum välja "Kalevipoja" ingliskeelse tõlke uusversiooni ning korraldas novembris eeposteteemalise rahvusvahelise konverentsi. Oma artiklis avab Summatavet "Kalevipoja" eri väljaannete illustreerijate ideeloolisi kaalutlusi ning analüüsib viimase "Kalevipoja" väljaande illustratsioonide põhjal kunstniku mõtte ning trükises realiseerunud tulemuse vahelisi erinevusi tähendusloome seisukohast.

Usundiloolase Reet Hiiemäe artikkel tugineb autori isiklikule praktilisele kogemusele saksakeelse uskumusolendite leksikoni tõlkimisel. Küsimus on laiem kui pelgalt keeleline: iga olendiga 
kaasneb usundiline kontekst, millel on lokaalsed erijooned, neid saab tuvastada aga ainult asjatundlikus võrdluses sihtkultuuri vastava pärimusega.

Assüroloog Vladimir Sazonov käsitleb Kesk- ja Uus-Assüüria kroonikate ja annaalide tõlkimise ning tõlgendamisega seonduvaid küsimusi. Vanima kirjanduse tekstid on sageli säilinud katketena, sestap tuleb ka tõlgitavaid sõnu või väljendeid, samuti nende tähendust osaliselt kontekstist tuletada. Aja jooksul muutusid tekstid keerukamateks nii oma vormilt kui sisult. Lõpuks on oluline ka tõlgendamise probleem: kui täht-tähelt tuleks vallutuste kroonikais esitatud kirjeldusi võtta.

Filoloog Sirje Kupp-Sazonov jätkab lingvistiliste tõlke probleemidega, tuues näiteid sellest, kuidas grammatilise soo olemasolu või puudumine püstitab eesti ja vene keelde või keelest tõlkijale huvitavaid probleeme ning pakub peamurdmist ka tõlgitud teksti lugejatele. Soolise võrdõiguslikkuse teemad jäävad tõlkijaid üllatama ilmselt veel paljudeks aastateks.

Kogumikku lõpetavad artiklid teevad sissevaateid meie lähemate sugulasrahvaste keelde ja kirjakultuuri. Keeleteadlane Heinike Heinsoo arutleb vadja keele õpetamise üle möödanikus ja tänapäeval, puudutades muuhulgas ka andragoogilisi küsimusi elatanud inimeste keeleoskuse arendamise kohta. Eritletakse suulise keele (murrakute) ning kirjakeele (normkuju) vahelisi erinevusi ning neist johtuvaid probleeme. Vadja keele puhul mängib olulist praktilist ja ideoloogilist rolli ka asjaolu, kas tekst on kirja pandud ladina tähtedes või kirillitsas. Artiklite osa lõpetuseks annab vepsa kultuuri asjatundja Enn Ernits põhjaliku ülevaate vepsakeelsetest trükistest läbi ajaloo. Teosed on periodiseeritud ning liigitatud lähtuvalt nende funktsioonist. Omaette väärtusega on artikli lõppu lisatud vepsakeelsete trükiste bibliograafia.

Aastaraamatu teises osas on päevakajalisemad kirjutised - Toomas Kiho kriitiline essee tõlgeteta kultuuri vaesestumisest ning sellega kaasnevatest ohtudest, projekti "Herba" kogumisaktsiooni ülevaade ning sissevaade Kirjandusmuuseumi Virtuaalse Keldri ehitamise protsessi. 
Aastaraamatu kolmas osa koondab traditsiooniliselt teavet kirjandusmuuseumi osakondade tegevuse kohta. Eraldi tabelisse on koondatud ülevaade Eesti Kirjandusmuuseumi 2011. aasta olulisematest sündmustest. Arhiivitöö, teadustöö ja humanitaarset uurimist populariseerivad üritused moodustavad meie maja igapäevaelu tuuma. Ürituste taga on alati järjepidev arhiivi- ja uurimistöö, mis kõrvaltvaatajale võib vahetevahel paista rutiinse ja mitte eriti märkimisväärse tegevusena, kuid mis pakub suuri elamusi neile, kes teadus- ja mäluasutuste tööga sisuliselt kokku puutuvad. Teeme ju kõik siin majas oma tööd eeskätt kogude kasutajatele ja uurimuste lugejatele mõeldes ning loodame, et selle tulemustesse süvenemine rõõmustab kõiki kirjandusmuuseumiga seotud inimesi.

Aastaraamatu visa valmimine (nii järjepidevuse kui tempo mõttes) osutab, et kirjandusmuuseum on oma traditsioonidest kinni hoidev asutus. Tänapäeva kiirelt muutuvas maailmas ei pruugi see alati olla konkurentsieeliseks, kuid lühiajalistest perspektiividest juhindumine ei saagi olla rahvusliku mäluasutuse eesmärk. Pikaajalises perspektiivis on meie ülesandeks jääda ellu Eesti kultuuri ja mälu säilitava ning tõlgendava asutusena, mille töötajate ja kogude usaldusväärsus annab oma panuse meie riigi ja rahva loo jätkumisse.

Olgu selle loo osaliseks ka käesolev aastaraamat.

Head lugemist! 

ARTIKLID 


\section{Kunstniku Kalevipoeg: eepose ja müüdi taasesitus Kristjan Rauast Gunnar Neemeni}

Kärt Summatavet

Teesid: Artikkel käsitleb müüdi ja eepose kujutamisega seotud kunstiteoseid, keskendudes "Kalevipoja" väljaannetele. Vaatluse all on kolm meetodit, mida kunstnikud on selle eepose raamatugraafika kujundamisel ning müüdi tegelaste ja sündmuste kujutamisel kasutanud. Eepos ja müüt on vaadeldavad inimese kujutlusvõime tulemustena, mille taasesitamisel põimuvad kunstnike teostes rahvalooming ja professionaalne kunst, üldised ja isiklikud ning igavikulised ja üldinimlikud teemad. Vaatluse all on ka kunstniku roll müüdi taasesitajana ning rahvaloomingu interpreteerimisel ilmnevad müüdi eetilise ja esteetilise tõlgendamise küsimused. Eepose kujutamisega seoses leiab käsitlemist ka kunstniku uurimistöö fenomen, mida eepose-aineliste teoste puhul alati ei pruugita väärtustada, kuid mis sellegipoolest mõjutab kunstnike loomingut.

Märksõnad: müüt, eepos, kunst, "Kalevipoeg”, loomemeetod, kujutlusvõime, inspiratsioon, müüdi taasesitus

\section{Sissejuhatuseks}

Eepos "Kalevipoeg" ning rahvapärased allikad ja muistendid, mis on ilmunud kogumikes "Kalevipoja esi-isad" (Eisen 1920), "Muistendid Kalevipojast” (Laugaste, Normann 1959) ja võrguväljaandes "Kalevipoeg" (1999), on kunstnikele omanäoliseks inspiratsiooniallikaks ja kujutlusvõimet avardavaks allikmaterjaliks, kuid loo- 
mingulise ülesandena tõsiseks väljakutseks. Kunstiteadlane Mai Levin on tabavalt märkinud, et 1935. aastal ilmunud "Kalevipoja" juubeliväljaandest on kujunenud Eesti iseseisvusaegse rahvusromantilise kunsti monument. Kuid ka Kristjan Raua loominguline lähenemine vajas aega harjumiseks. Raua arhaiseeriv, jõuliselt üldistav stiil paistis 1930. aastatel paljudele primitiivsena, mistõttu Tartu Kunsti ja Kirjanduse Klubi korraldas 1937. aastal kunstniku teoste üle "kohtu", mis pidi seda stiili laiemale publikule seletama ja õigustama (Levin 2010: 107-108). Raua loodud "monument" on nüüdseks pälvinud üldise tunnustuse, kuid seda enam tabab iga järgnevat "Kalevipoja" illustreerijat publiku kõrgendatud ja kriitiline tähelepanu. Käesolev artikkel on katse anda põgus ülevaade "Kalevipoja" eepose teemal loodud erisuguse loomesõnumi ja suunitlusega raamatugraafikast ning sealhulgas tutvustada, kuidas kunstnikud on interpreteerinud eepost ka siis, kui neil puudub otsene kokkupuude müüdi ja rahvaloominguga.

\section{Loomeprotsess ja selle kirjeldamine}

Kunstnikult oodatakse tema kujutlusvõime ja ümbritseva reaalsuse vahekordade originaalset väljendust. Kunstiteadlase Ernst H. Gombrichi sõnul vaimustab looja oma kaasaegseid tihti just sellega, mis tema teostes on traditsioonilisest erinev: "Iga kunstnik arvab olevat ületanud eelmise põlvkonna poolt saavutatu ja et tema seisukohalt on ta ise jõudnud kaugemale kui keegi teine enne teda" (Gombrich 1997: 8-9). Ta lisab, et kunstnikel on aeg-ajalt selline tunne, et nad on avastusretkel, nad tahavad vaadata maailma uudse pilguga ja heita kõrvale kõik üldtunnustatud arusaamad ja eelarvamused (Gombrich 1997: 15). Gombrich on välja toonud ka selle, et neist kategooriatest, mille üle kõrvalseisjad arutlevad, nagu näiteks ilu või väljenduslikkus, räägivad kunstnikud harva ning seda, mille üle kunstnik muret tunneb, kui ta oma töid kavandab, visandeid teeb või otsustab, kas taiest lõpetatuks pidada või mitte, on loojal raske sõnades väljendada (Gombrich1997: 32). 
Paljud uurijad on arutlenud selle üle, kas ja mil määral on võimalik kunstiprotsessi kõiki aspekte eksplitsiitselt kirjeldada või sõnastada (vt nt Polanyi 1962; Schön 1983; Nonaka et al. 2000; Biggs 2004; Scrivener 2006; Niedderer, Imani 2008) ning rõhutavad, et isiklik kogemus, mida kunstnik loomeprotsessi ajal teadlikult või teadvustamata kogeb, on tihti seotud varjatud teadmiste ja oskustega, mille sõnastamiseks puudub loojal otsene vajadus või varasem kirjeldustraditsioon.

Claude Lévi-Straussi sõnul asub kunst poolel teel teadusliku teadmise ja müütilise või maagilise mõtlemise vahel. Kunstnik sarnaneb ühtaegu teadlase ja meistrimehega: käsitöölise vahenditega valmistab ta materiaalse objekti, mis on ühtaegu ka intellektuaalne objekt (Lévi-Strauss 2001: 46). Kunstnik uurib ja mõtestab maailma oma valdkonna meetodeid rakendades ning loomeprotsess avardab looja enda kujutlusvõime piire, luues uusi elamusi ja kogemusi, mis argises tegelikkuses ei eksisteeri, ning tema teosed avaldavad mõju ka vaataja kujutlusvõimele.

Juri Lotman on kirjutises "Kunsti fenomen” märkinud, et kõiki kunstiloomingu liike võib kujutleda mõtteeksperimendi erikujudena (Lotman 2001: 173-174). Ta on seisukohal, et kunst loob põhimõtteliselt uue tegelikkusetasandi, mis erineb tegelikkusest tunduvalt suurema vabaduse poolest. Oma vabaduserohkuse tõttu teeb kunst võimalikuks niihästi keelatu kui ka võimatu ning on reaalsusele otsekui vabaduse sfääriks. Kunst loob oma maailma ning võib rikkuda muu hulgas ka tavade ja harjumuste ning koguni aja ja ruumi seadusi. Ta rõhutas, et kunsti üks geniaalseid omadusi on mõtteeksperiment, mis lubab kontrollida maailma mingite struktuuride puutumatust ning sellega määratakse ka kunsti ja tegelikkuse suhe. Kunst on tunnetusvahend ja eeskätt inimese tunnetamise vahend (Lotman 2001: 170-172).

Kogumikus "Semiosfäärist" on Lotman kirjutanud, et kunsti mõjujõud muudab kunsti ülimaks tunnetusjõuks - kõrgeimaks tipuks, kuhu inimene teda ümbritsevate maailmade varjatud saladuste valdamisel võib tõusta (Lotman 1999: 182). Samas teoses on ta esile toonud ka kunstiteose vaataja rolli ning rõhutanud, et arhailise loomingu omapära seisneb tema esitaja ja kuulaja funkt- 
sioonide jaotuses. Folkloori arhailised vormid on rituaalsed ning neil puudub passiivne auditoorium. Arhailine rituaal eeldab arhailist maailmatunnetust, mida kunstlikult taaselustada ei ole võimalik. Esitaja ja vaataja ühtesulamine eeldab kunsti ning selle tegemise ühtesulamist, keskendumist loomeprotsessile ja mitte vaid selle tulemusele. "Ajaloolisse aega" kuuluva kunsti puhul toimub jagunemine esitajateks ja auditooriumiks, mispuhul kunsti vaataja on samal ajal tegelikkuses mitte-vaataja: ta näeb, kuid ei sekku, on kohal, kuid ei tegutse ja ei osale kunstiruumis (Lotman 2001: 178-179).

Tänapäeva kunstipublik, kes ei osale teose loomisprotsessis, võib jäädagi teadmatusse, milliseid tunde- ja mõttetasandeid looja oma teosega puudutab. Argisel tasandil loodud teoseid võib igaüks oma kogemuse alusel isikupäraselt interpreteerida, neile tähendusi luua ja tuttavana tunduvaid seiku omal kombel taasesitada, kuid müütilise või müstilise kogemuse mõistmiseks vajab vaataja teadmisi ja kogemusi, mis kuuluvad tunnetusvälja, mille kunstiväline kirjeldamine on raske või isegi võimatu. Kunstnik võib vaataja abistamiseks paljastada teatud võtmesõnad või selgitada, mida ta tundis või mõtles ning sellega vähendada kunstiruumi "varjatud saladuse" astet, kuid vaataja loomeprotsessiga ühtesulamise võimalused jäävad siiski teatud astmeni piiratuks.

Vaatajal on kunstnikust meistrimehe ja käsitöölise tunnetustasandiga liiga vähe ühiseid kogemusi, sest teose looja varjatud oskuste uurimisel ja kirjeldamisel on lühike ajalugu ning praktikud-kunstnikud osalevad selles uurimisprotsessis lühikest aega. Kunstniku peamised töövahendid on kujutlusvõime, emotsioon, tunne ja isiklik kogemus, aga ka treenitud oskused, mille kõrgtasandil omandamine on eeltingimuseks professionaalsele kunstiloomingule. Autori mõtete ja tunnete edastamine toimub kunstiruumiga seotud isikupärases väljenduskeeles, loomingulist "käekirja" treenitakse kunstikõrghariduse algastmest alates ning see on pikaajaline ja sõnadega raskesti kirjeldatav protsess (vt nt Summatavet 2010a: 22). Eesti professionaalse kunstihariduse kõigil astmetel toimub teatud süsteemne õppeülesannete järjestikune omandamine, mille käigus ópitakse oskusi ümbritseva maailma 
uurimiseks, mõtestamiseks, kujutamiseks, interpreteerimiseks ning loometöö vahendite-oskuste abil tõlkimiseks, esitamiseks ja uuendamiseks.

\section{Müiut ja selle kujutamine}

Sünteesides eri allikaid ja uurides kunstiloomingu kaudu teadusliku teadmise ning müütilise või maagilise mõtlemise vahelisi seoseid, võib kunstnikupositsioonilt öelda, et müüt on iidne lugu, millele kuju andmiseks peab kunstnik müüditegelikkusest usaldusväärse teose sünnitama. Müüdi kujutamine ei ole kerge ülesanne, sest üleloomulik muistne lugu on mitmekihiline, suure tähendusväljaga ning inimeste kujutlusvõime poolt korrastatud avar muinasmaastik, mida pole võimalik argieluks taandada (vt Summatavet 2010a, 2010b). Selleks, et kunsti väljendusvahendite abil müüdi igavikulisi ja üldinimlikke teemasid nähtavaks kujustada, tuleb kunstnikul õppida tundma rahvaloomingut, häälestuda loomeprotsessi kaudu arhailisele maailmatunnetusele ning uurida loomeprotsessi kaudu poeetilises sõnas väljendatud arhailisi kujutlusi.

Matthias Johann Eisen on "Eesti mütoloogia" (1919) sissejuhatuses kirjutanud, et sõna kitsamas mõttes tähendab müüt iseäralikku ennemuistset juttu, kuid laiemas mõttes tavalistest inimestest kõrgemal seisvate, muistsete olevuste tegevuse kirjeldust. Esivanemad punusid oma teadmise, ettekujutuse kõrgematest olevustest müütidesse ning püüdsid neile n-ö käega katsutava ja silmaga nähtava kuju anda (Eisen 1995: 4). Erinevate käsitluste hulgas on müüdi mitmetähenduslikkuse tagamaid seostatud ka rahvausundi, suulise ja ainelise rahvaloomingu ning šamanismiga (vt n Eliade 1974; Lang 1999; Siikala 2002; Hoppál 2008). Seppo Knuuttila märgib artiklis "Nähtud ja kujutatud müüdid", et müütide kaudu esilekerkivad küsimused algupärast, piiridest, saladustest ja tulevikust vaevavad inimesi tänapäevani. Kuigi müütide tõlgendused ja rakendused muutuvad aja jooksul, on nende ülesehitus ja nende üle toimuvad arutlustavad oma aegluselt üleajaloolised. Müüte 
korratakse, tõlgendatakse ja tehakse nähtavaks kõigil kunstialadel (Knuuttila 2010: 9).

Loomisprotsess, mille käigus loob kunstnik müüdile nähtava kuju ja esituse, eeldab süvenemist suulises pärimuses talletatud lugude allikatesse. Kunstniku loomeprotsessi eesmärk võib olla müüditeemade illustreerimine, kuid ka kunsti kaudu osalemine arhailise kogukonna sees jagatud kogemuses ning elamuses. Suuline rahvalooming on huvitav inspiratsiooniallikas, mille interpreteerimisel ja illustreerimisel lähtub kunstnik teatud oskustest, kogemustest ja kujutlusvõimest.

Hasso Krull kirjutab oma essees "Loomise mõnu ja kiri", et suuline kirjandus, laul ja laulmine on rituaalne toiming, millega keele ja maailma kosmiline ühtsus täide viiakse. Iga laulmine on alati tagasitulek ja uus algus. Laulmine tähendab rituaalset tagasitulekut, korraga kõige kokkukogumist ja vallapäästmist. Sellepärast on laulikul kosmogooniliselt keskne asend ja talle omistatakse erilist väge. See maailm on loodud laulja ja tema kogukonna jaoks ning ei ole enam võõras, vaid kodune ja omane (Krull 2006: 10).

Nii nagu muistne laulik, kuulub ka müüti ja eepost mõtestav ning kujutav kunstnik muistse loo taasesitajana arhailise müütilise maastiku keskpunkti. Kunstnikul on müüdi taasesitajana alati teatud vastutus ja roll, sest tahes või tahtmata osaleb ta oma kujutlusvõime abil üldinimlikes kogemustes, mida on põlvest põlve talletatud ning edasi antud suulise ja ainelise rahvaloomingu kaudu. Kunstniku loojavabadusega kaasnev ülesanne on sel puhul analüüsida ka loomisprotsessi eetilisi ja esteetilisi eesmärke, et teadlikult või ka intuitiivselt valida sobiv esitusviis ning loominguline lahendus, millel on sihtrühm ja sõnum.

Ülo Valk kirjutab 2011. aastal ilmunud "Kalevipoja” väljaandes, et "Kalevipoja" lauliku esituses hakkab sõnamaagiline laulmine toimima, äratades ellu poeetilises sõnas varjatud müüdilise alge, mis lubab kõnelda tõtt kõige oleva päritolust ning jutustada sellist loomislugu, mis käivitab loomisprotsessi. "Kalevipojas" võtab kuju grandioosne vaatepilt kaugest ja eriskummalisest maailmast, mis on rohmakas, ürgne ja lummav (Valk 2011: 532). Kunstniku loomisprotsessi võtmeküsimuseks ongi sõnumi leidmine, mis ins- 
pireerib teda teost looma ning valima sobivad meetodid ja võtted, et seda kauget ja eriskummalist maailma, "grandioosset vaatepilti" tõepäraselt või kunstnikupositsioonilt ja oma vaatenurgast esitada.

Selleks, et taasesitada või interpreteerida müüditegelikkust, püüab kunstnik müüdi teemasid mõtestatult ja elamuslikult isikliku ruumi - keha ja kujutlusvõime - kaudu kogeda, müüdis empaatiliselt osaleda ja tegelaskujudega samastuda, et loomeprotsessi ajal tekkivaid elamusi ja sõnumeid kunsti vahendite abil nähtavasse keelde tõlkida. Kui kunstnik õpib usaldama pärimust, märkab ja kogeb ta rahvaloomingu esitamisel tekkivaid iidseid rütme, kujundeid, maastikke, värve ning tunneb ja mõtestab neid salapäraseid kosmogoonilisi kogemusi, mis mõjutavad loomisprotsessi ajal tema teadlikke ja intuitiivseid loomingulisi otsuseid.

Kalevipoja-aineliste teoste puhul on kunstnikud lähtunud nii professionaalse kunsti kui rahvapärase loometöö praktikast, kuid ka vastavale ajastule omastest teadus- või kunstikäsitlustest. Nad on kujutanud müüditegelasi ja erilisi sündmusi nii lugemiskogemusele kui ka eepose tõlgendustele toetudes. Mõnede pärimust laiemalt mõtestavate kunstnike tööprotsessi võib teatud juhtudel võrrelda ka rahvaloomingu autorite loomeprotsessiga, sest kunsti kaudu arhailisi kujutelmi läbi elades on loojad püüdnud edastada üldinimlikke kogemuslikke ja elamuslikke teadmisi, mida argises kõnekeeles on raske väljendada.

Müüt kui arhailiste kujutluspiltide kogum, mida antakse edasi kogukonna sees jagatud vaimsete kogemuste ja elamuste mõtestatud kujutluspiltide kaudu, kogetakse ja mõtestatakse professionaalse kunstniku poolt uuesti läbi, esitatakse uuel kujul. Müüdi ja eepose alastest teadmistest ning loome-eesmärkidest sõltub, kuidas ja kuivõrd sügavuti autor süveneb "Kalevipoja” lugudesse ning millises loomevõtmes ta otsustab eepost kujutada. Kunstnik võib teatud piirini mõista ka kunagiste laululoojate ja müütilise loomisloo esitajate vaimusilmas sündinud kujutluspilte, mida tekst edasi annab. Ta eksperimenteerib, sünteesib ja loob neist teadetest oma struktuuri, esitades rahvaloomingu alusel sündinud kogemusi ja ettekujutusi professionaalse kunsti visuaalse kommunikatsiooni süsteemi, kujundite, märkide ja teadete keeles. 
Mõtteeksperimendid, mis on inspireeritud arhailisest maailmatunnetusest ning lähtuvad samas ka loomevabadusest, lubavad oletada, kuhu inimene teda ümbritsevate ja läbivate maailmade varjatud saladuste valdamisel võib tõusta. Müüdi taasesitajana võib tänapäeva kunstnik küll märgata ning omal kombel mõista argises ja pühas keeles esitatud pärimusdetaile, kuid erinevaid tähendusvälju loov müüdi taasesitus on alati seotud ka müüdi ja eepose käsitlustest väljaspool asuvate mõjuteguritega.

\section{Müiut ja "sotsiaalne tellimus"}

Kunstipublikul on teatud ootused, harjumused ja eelarvamused, milline võib või peab eepos-monument olema. "Kalevipoega" illustreerinud kunstnikel on vaataja ja tellija antud keeruline loomeülesanne, mis piirab loojavabadust ning on rohkemal või vähemal määral seotud üldiste huvide ja ootustega, kuid paratamatult sõltunud ka poliitilisest oludest ja ideoloogilisest survest. Kuigi artikli eesmärk on vaadelda "Kalevipoja" väljaandeid kujundanud kunstnike loomemeetodeid ning mitte analüüsida ajaloolisi või poliitilisi aspekte, on siinkohal otstarbekas esile tuua mõningaid näiteid tellijapoolsest huvist või survest, mis on mõjutanud konkreetsete väljaannete kujundusprintsiipe.

Näiteks "Kalevipoja" viienda trüki saatesõnas selgitas August Annist, et teos otsustati kirjastada n-ö esteetilise rahvaväljaandena ehk illustreerituna, sest "Ilustatud Kalevipoja" küsimus oli päevakorral juba 1911. aastast alates - rahvuskirjanduse esimene ja mõjurikkaim suurteos tuli viimaks ometi varustada väärika välimusega välismaa suurte vastavate väljaannete eeskujul (vt Annist 1936: 287, 290). Kuigi Eesti Kirjanduse Selts tellis Raualt "Kalevipoja" juubeliväljaande illustratsioonid ning lühikese ajaga valmis kunstnikul hulk töid, ei pandud kõiki uudisteoseid väljaandesse, vaid raamatu kujunduses kasutati ka vanemaid teoseid, et katta illustratsioonidega kogu eepose sündmustikku (vt nt Levin 2010: 107). 
Järgmise, 1946. aastal vahetult pärast sõda Nõukogude okupatsiooni algusperioodil ilmunud "Kalevipoja" saatesõnas märkis Oskar Urgart, et seoses väljaandega oli raskusi muu hulgas ka teose mõtte ning laadi kindlaksmääramisel ja selle õigustamisel, süüdistades 1935. aastal ilmunud "Kalevipoja" väljaandjaid katses eepost ära kasutada "agressiivsetes natsionalistlikes huvides" (Urgart 1946: 235-236). Väljaande kujundaja Paul Luhtein lahendas ülesande rahvakunsti ornamente stiliseerides, sest rahvakunsti kasutamine oli aktsepteeritud ning seega ka üks väheseid turvalisi viise, kuidas poliitilisi ja ideoloogilisi teemasid vältida. Keraamik ja kunstiteadlane Helene Kuma, kes osales Nõukogude okupatsiooni algusperioodil rahvakunsti puudutavates diskussioonides, on oma ajaloolises tagasivaates selgitanud, et situatsioonis, kus kodanliku pärandi kasutamine oli rangelt keelatud, lähtusid kunstnikud põhiliselt rahvakunstist, selle ornamentidest ja ainelise pärandi kõrval ka rahvaluulest, müütidest ja muistenditest (Kuma 2001: 27).

Kaks aastat hiljem, 1948. aastal kritiseeriti poliitilise ja ideoloogilise rünnaku käigus muu hulgas Adamson-Ericut, Paul Luhteina, Günther Reindorffi rahvusliku ornamendi liigselt loomingulises interpreteerimises ning süüdistati formalismis isegi mitmeid sõja ajal Nõukogude tagalas töötanud eesti kunstnikke (vt nt Kirme 1999: 365-420). Poliitilise ja ideoloogilise surve tingimustes ilmusid 1951. aastal Alo Hoidre, Ott Kangilaski, Richard Sagritsa, Richard Kaljo ja Edith Parise ühistööna valminud "Kalevipoja" illustratsioonid. Arvestades tollaseid teravaid ja hävitavaid diskussioone ning kunstnike vastu suunatud repressioone, on Eduard Laugaste raamatu järelsõnas 1935. aasta "Kalevipoja" kujundust nimetanud dekadentlikeks illustratsioonideks, mis moonutavad Kalevipoja kuju, tema demokraatlikku sisu ja vormi (Laugaste 1951: 344). Ta märkis, et "EK(b)P Keskkomitee VIII pleenumi otsuste täitmise tulemusena ilmub nüüd Kalevipoeg Nõukogude Eesti lugeja ette uuesti oma õigel kujul" (Laugaste 1951: 345).

Laugaste järelsõnas ilmunud kriitika põimis omavahel osavalt "Kalevipoja" nii venestamise kui ka Nõukogude võimuga, esitades tollaseid ametlikke seisukohti. Võrdlusmaterjaliks võib tema järelsõna kõrvutada ka samas ideoloogilises võtmes kirjutatud eepose 
looja eluloolise ülevaatega “Fr. R. Kreutzwald 1803-1882” (vt Sõgel et al. 1953). Kakskümmend kaks aastat hiljem, 1975. aastal ilmunud "Kalevipojas" tõstis Endel Nirk Raua Kalevipoja-ainelise loomingu aga "auväärseimale kohale", tunnustades tema aastakümneid kestnud tööd eepose ja eesti muinsuse ainestikuga ning rõhutades, et eeposel on eriline roll eri kunstialade "edasiloomingu" allikana (Nirk 1975: 273).

Kunstnikele esitatud lähteülesanne, looja roll ja positsioon "Kalevipoja" interpreteerimisel ning rahvaloominguga eksperimenteerimisel tekitab tagasivaates rea olulisi küsimusi, kuid kuna käesoleva artikli eesmärk ei ole anda hinnanguid kunstnike loomingule ega analüüsida ajaloolis-poliitilisi aspekte, siis neid siinkohal pikemalt ei käsitleta. Keskendun järgnevas konkreetsetele Kalevipoja-teemalistele teostele, kitsamalt raamatugraafikale, et tutvustada neid loomemeetodeid ja eksperimente, mida Eesti kunstnikud on "Kalevipoja" kunstilisel kujutamisel kasutanud. Kuigi kujutavas kunstis on Kalevipoja-aineliste teoste loomisel rakendatud väga erinevaid loomevõtteid, võimaldavad eelpool toodud põgusad näited mõista, millise surve või mõju all on kunstnikud "Kalevipoja" tervikteose kujundamisel töötanud ning millisel määral teinud teadlikke kompromisse isikliku loominguvabaduse ja vaataja-tellija ootuste tasakaalustamiseks.

Siinkohal on asjakohane lisada, et empiirilisele materjalile toetudes on praktikust professionaalne kunstnik-pedagoog, kes jagab "Kalevipoja" illustreerijaga sama kultuuri- ja haridustausta või on omandanud teatud üldise erialase "kirjaoskuse" ja "lugemisoskuse", suuteline vaatajana selgelt eristama "Kalevipoja" kunstnike loomemeetodeid, mida looja iga konkreetse teose puhul on rakendanud. Kunstipraktikud, kes jagavad sarnaseid teadmisi, oskusi ja kunstiprotsessi kogemust, võivad selle alusel teosesse süvenedes ja temaatilist või ajaloolist konteksti piisavalt teades märgata teose looja loomeprotsessi või -eksperimendi nüansse. Kunstnikust vaataja süvenemise astmest sõltub, millisel tasemel toimub ühtesulamine ning millisel eesmärgil soovitakse vaadeldavaid loomeaspekte kirjeldada. 
Isiklikele kogemuslikele teadmistele ja oskustele ning erialastele diskussioonidele tuginedes võib "Kalevipoja" väljaannetele loodud teoste puhul välja tuua vähemalt kolm loomemeetodit, mis erinevad üksteisest nii inspiratsiooniallika kesksete rõhuasetuste valiku kui ka loomesõnumi poolest. Käsitlen ka juhtumeid, kui kunstniku algne idee ei pääse mõjule, sest väljaandja-tellija muudab autori loomesõnumit oluliselt.

\section{Esimene meetod: illustratsioon ja stilisatsioon}

Esimene meetod, mida kunstnikud "Kalevipoja" väljaannetes on kasutanud, on eepose illustreerimine ja stiliseerimine. Illustratsioon on teksti selgitav, täiendav või kaunistav pilt (ENE 3: 567) ning stilisatsioon tegelikkuse vormide ühtlustamine, skemaatiline kujutusviis, mis on omane dekoratiivkunstile, sh ornamentikale (EE 8: 653).

Stilisatsiooni ja ornamentikaõpetust on eesti professionaalses kunstikõrghariduses õpetatud juba selle algusaastatest alates (vt nt Raunam 1964: 20-21), sest 1914. aastal loodud joonistuskursustest välja kasvanud Tallinna Kunstitööstuskoolis (hiljem Riigi Kunsttööstuskool, praegu Eesti Kunstiakadeemia) töötasid õppejõud, kes olid hariduse omandanud Peterburi Parun von Stieglitzi Tehnilise Joonistamise Keskõppeasutuses (EE 8: 652). Peterburi kooli eeskujul kuulusid Kunsttööstuskooli õppekavadesse mitmesugused kompositsiooni ja stilisatsiooni õppeülesanded, mille käigus õpiti stiliseerima ka rahvakunsti ornamente (vt nt Päts 1928; Kalm 2010: 593). Rahvakunsti stiliseerimine ja pärimuse illustreerimine võimendus õppekavades Nõukogude perioodil, kuid mitmed stilisatsiooniülesanded on tarbekunsti erialadel osaliselt säilinud praeguseni. Pärast II maailmasõda loodud "Kalevipoja" illustratsioonide ja stilisatsioonide autorite hulgas on mitmeid kunstipedagooge, kes on väljaande kujundamisel lähtunud nii eepose tekstist kui ka ainelise rahvaloomingu kunstilisest interpreteerimisest.

Paul Luhtein on 1946. aastal ilmunud "Kalevipojale" loonud vaid ühe dekoratiivse figuraalse kompositsiooni, milles üksik 
muistne sõdalane võitleb raudrüüs rüütlitega. Autor annab teosega vihje sõjajärgsele perioodile omases poliitiliselt korrektses võtmes, tähistades üksinda arvukatele vaenlastele vastu astuva kangelase kujutamisega muistset vabadusvõitlust saksa ristirüütlite vastu. "Kalevipoja" kujunduses on kunstnik lähtunud siiski peamiselt rahvakunsti esemete ja ornamentide stiliseerimise võtetest. Eepose lugusid tähistavates päisliistudes ja vinjettides on ta osavalt komponeerinud dekoratiivseid kujunduselemente rahvaloomingus leiduvate detailide ainetel ning meisterlikult mustreid ja lugude tegelasi stiliseerides loonud anonüümseid ja lihtsustatud teksti toetavaid kaunistusi.

Evald Okas kujutas 1961. aastal ilmunud "Kalevipoja" illustratsioonides inimnäolist kangelast, kes töötab ja võitleb, puhkab ning pidutseb. Kalevipoeg, illustratsioonide keskne tegelane, on justkui üks meie hulgast, kellele pole võõrad ka inimlikud tunded ja nõrkused. Kunstnik on arhailist lugu esitanud argitegelikkuse võtmes ning müütiliste tegelaste stiliseeritud, kohati võõrapärased rõivad ning skemaatiliselt tähistatud tarbeesemed paigutavad piltidel kujutatud sündmused ja tegevused ebamäärastesse lähisajanditesse. Autor kujutas ja tähistas sündmusi, mis iidset lugu kaunistavad või ümber jutustavad, kusjuures tema eesmärk ei olnud esitada tõetruud pärimuskeskkonda või müüditegelikkust.

1961. aastal ilmunud Eno Raua "Kalevipoja" ümberjutustuse ehk nn laste-Kalevipoja illustratsioonide autor on Ants Viidalepp. Kunstnik on väljaande kujunduses eepose lugude algused tähistanud stiliseeritud figuratiivsete kompositsioonidega ning proosavormis lühendatud Kalevipoja-lugudes kirjeldatud sündmuste detailidega. Ka vahelehtedele trükitud ekspressiivsed värvilised teosed kujutavad üksikuid eepose sündmusi ja tegelasi, keda kunstnik on justkui kõrvaltvaatajana pildile fikseerinud, lihtsustanud ja mitmesuguste detailidega kaunistanud. Stiliseeritud rõivad, tarbeesemed ja keskkond on esitatud lihtsustatud märgiliste tähistustena, mis aitavad kunstnikul positsioneerida sündmusi ja tegelasi 20. sajandist kaugemasse, n-ö muistsesse aega.

1976. aastal ilmunud Eno Raua "Kalevipoja" ümberjutustuse on illustreerinud Heldur Laretei. Kunstnik kujutas Suurt Tamme, 
Kalevipoega ja sarvikuid humoorikate ning karikatuurilaadsete tegelastena toimetamas ja jõudu katsumas, mõõka proovimas või sängi veeres jooki rüüpamas. Peamiselt lastele suunatud teoses on muistne lugu esitatud lihtsustatult, skemaatiliselt ja dekoratiivselt. Ühemõttelisena esitatud pildid ei jäta ruumi vaataja kujutlusvõimele, illustreerides ja stiliseerides teksti ilma autoripoolsete loominguliste püüdlusteta rõhutada müüdi mitmetähenduslikkust.

Loomemeetod, mille puhul kunstnik keskendub peamiselt eepose illustreerimisele ja rahvaloomingu stiliseerimisele, kirjeldab "Kalevipoja" tegelasi ja sündmusi lihtsustatult, pigem üldistavas visuaalselt esitatud ümberjutustuse vormis ning illustratsioonid on lugemise abivahendid teksti ilmestamiseks ja kaunistamiseks.

\section{Teine meetod: kunstniku "käekiri" ja loomesõnum}

Teine Kalevipoja-teemalistes väljaannetes kasutatud loomemeetod lähtub kunstniku isikupärasest "käekirjast" ja loojasõnumist. Selle meetodi puhul autori kujutlusis tekkinud tunded, ideed ja loomesõnumid sünnivad küll eepose teemadest, kuid kunstnik loob oma teostes mitmetähenduslikke ja lugeja kujutlusvõimet ergutavaid uusi võimalusi, mis julgustavad vaatajat ka oma kujutlusvõime abil eeposesse süvenema. Seda meetodit on teiste hulgas kasutanud näiteks Jüri Arrak, Jaan Tammsaar ja Andres Tali.

1985. aastal ilmunud Enn Vetemaa romaanile "Kalevipoja mälestused" on Jüri Arrak loonud 1982. aastal valminud joonistused. Nendes teostes toob autor Kalevipoja loost esile oma varasemale kunstniku-käekirjale omaseid muistseid tegevusmaastikke. Arhailisena mõjuvas keskkonnas toimuvates sündmustes osalevad ebamaised ja üleloomulikud tegelased, kusjuures argiste tegevuste ja sündmustena näivatel situatsioonidel ei ole siiski mingit seost argielu tegelikkusega. Kunstnik esitab Kalevipoja loost inspireeritud elamuste ja vaimsete kogemuste põhjal loodud mõjusaid kujutluspilte, kuid annab ka vaatajale võimaluse siseneda sellele muinasmaastikule ning osaleda oma kujutlusvõimele toetudes eepose lugudes kirjeldatud sündmustes. 
1998. aastal ilmunud Eno Raua ümberjutustuse "Kalevipoeg" on kujundanud Jaan Tammsaar, kes esitab arhailist müüti loomisloo loojapositsioonilt. Muistse lauliku kombel toob kunstnik pilt pildi haaval nähtavale arhailise müütilise maastiku - ta loob kosmilise avaruse, pimeduses aimatava ning seejärel koiduvalguses nähtavaks muutuva vetevälja, mille kohale saabub kotka seljas lendav ja maastikku vaatlev kangelane. Kalevipoega tähistab ta vaid harvadel piltidel väikese ja kaugeneva kujuna, kes pigem sulandub ümbritsevasse hiiglaslikku keskkonda. Konkreetsete eepose tegelaste kujutamise asemel loob kunstnik arhailist kultuurimaastikku, millest kerkivad esile tähenduslikud detailid ja üleelusuuruses etnograafiline pärand, mis markeerivad iidset lugu ja Kalevipoja tegude tagajärgi sümbolite ja märkide keeles. Müüdi taasesitajana loob ta oma teostesse tunnet ja salapära, pühana ja samas ka ohtlikuna mõjuvat kujutlusmaastikku, kus autori isiklik elamus ja kujutlusis tekkinud kogemus põimitakse osavalt iidse looga.

"Kalevipoja" 2009. aastal ilmunud väljaande illustratsioonide ja kujunduse autor on Andres Tali. Kunstnik on raamatu ilmumise puhul öelnud, et väljaande kujundamisel oli tema eesmärk vältida väljakujunenud stampe, eeskujusid ja tuttavaid kujundeid, ning rõhutanud, et Kalevipojas on mitmeid jooni tema enda iseloomust (vt nt Sibrits 2009). Autor elab eepose tegelaste nahas isiklikult läbi "Kalevipoja" lugu, lähtudes seejuures oma kujutlusvõimest, kunstikogemusest ja loojavisioonist.

Tali arvates on Kalevipoeg argipäeva-inimene, kellel on oma elusaatus, mis on "kaunis dramaatiline oma tõusude ja langustega". Sirje Helme lisab, et tulemus on ajale vääriline, sest Tali Kalevipoeg on tänapäevane mees, kes oma eksistentsiaalsete vaevade käes piinleb ning mõtlematute tegude käes kannatab, mida eelmine Kalevipoeg kindlasti ei teinud (Tralla 2009). Tali on kujukas näide nüüdisaegsest kunstnikust, kes eepose loo kujutamisel lähtub lugemiskogemusest, omaenda vaimsetest, füüsilistest ja üldinimlikest 
läbielamistest ${ }^{1}$ ning ka tänapäeva loojaid mõjutavatest kujutava kunstiga seotud väärtushinnangutest ja tõekspidamistest.

Tali seiskohtadega sarnastele järeldustele on jõudnud ka mitmed "Kalevala" eepost kujutanud tänapäeva kunstnikud. "Uue Kalevala” 160. juubeliaasta (2009) eel kutsuti Kalevala-seura algatusel 10 Soome kujutavat kunstnikku ja heliloojat 2008. aastal omal valikul eepose runo-teemadest muusikalisi või pildilisi tõlgendusi looma. Taiteilijoiden Kalevala (Kunstnike Kalevala) projekti lähtekoht oli, et müüdid on ühel või teisel aistingulisel viisil esitatud (kõneldud, lauldud, maalitud, vormitud, tantsitud) kultuuri väljendused. Knuuttila sõnul müüdi esituse puhul ei ole küsimuseks, kas esitus on väljamõeldis või tõde, vaid milliseid mõtteid ja tundeid müüt äratab, kuidas ta mõjub, kuidas ta paigutub teiste müütiliste esituste ja kunstide ajaloosse (Knuuttila 2010: 9).

2009-2010 laienes Taiteilijoiden Kalevala projekt Soomest Granadasse (Hispaania) ja Benini (Aafrika) ning Kalevala 175. juubeliaasta tähistamiseks viisid Jyväskylä Ülikool ja Granada Ülikool läbi uurimis- ja kunstiprojekti Kalevala granaína, milles osalesid lisaks kümnele Soome kunstnikule ka 13 Hispaania kunstnikku. Annika Waenerbergi ja Manuel Vélez Cea uurimisprojekti käigus selgus, et tänapäeva kunstnikud tõlgendavad müüte tihti intuitiivselt, tundes eelkõige huvi mitte ajaloo, vaid müütide poolt äratatud isiklike kujutluspiltide ja tundepuhangute vastu (Vélez Cea, Waenerberg 2010: 5). Knuuttila sõnul põimuvad üldine ja isiklik, väline ja sisemine mütoloogia teineteisega nii, et esitustest võib eraldada müütiliste teemade personaalseid kompositsioone, milles leidub peegeldusi nii müütide maailmaajaloost kui ka kohalikest mikrokosmostest (Knuuttila 2010: 10). Kuigi Taiteilijoiden Kalevala teostes justkui polegi nähtavat ühendust Kalevala-kunsti varasema traditsiooniga, visualiseerivad need teosed igaüks omal viisil just neid "Kalevala" teemasid, mis paeluvad tänapäeva inimesi. Taiteilijoiden Kalevala on näide sellest, kuidas minevikku võib naasta ela-

1 Graafiku ja meediakunstnikuna on Tali varemgi kasutanud iseennast mitmete teose peategelase ja uurimisobjektina (vt nt "Iha ja igatsuse instrumendid - Mängi minuga” 2003, "Iha ja igatsuse instrumendid ...Sick and Tired...” 2004; “11 stilli/11 stills” 2006). 
muslikul ja sümboolsel viisil, kuid seda võib alati katsutavaks ja nähtavaks teha ka uuel viisil (Knuuttila 2010: 14).

Soome uurimis- ja kunstiprojekti tulemustele toetudes nähtub, et eelpool kirjeldatud loomemeetod võib inspireerida ka noorema põlvkonna kunstnikke, kellel pole kokkupuudet elava pärimusega ning kes soovivad pigem lõhkuda ja uuendada eepose tõlgendustraditsiooni seniseid piire, tõlgendades eepost lugemiskogemuse põhjal tänapäeva inimese isiklike elamuste, väärtushinnangute ja elukogemuse võtmes.

\section{Kolmas meetod:}

\section{loomislugu kui loomisprotsessi käivitaja}

Kolmanda loomemeetodi puhul on tähelepanu keskpunktis rahvaloomingu uurimine ning kunstniku pärimuse-alased süvendatud teadmised. Suulise ja ainelise kultuuripärandi tundmine täiendab ning mitmekesistab loovisiku teadmisi, olles loomeprotsessi käivitavaks inspiratsiooniallikaks, mida loovalt mõtestades seotakse autori isikupärase filosoofia ja poeesiaga. Selle meetodi puhul ei lähtu kunstnik teoste loomisel ainuüksi eeposest, vaid keskendub laiemalt rahvaluulele ning arhailistele kujutlus- ja loomisviisidele, mis tuuakse nähtavale "Kalevipoja" kaudu.

Selle loomemeetodi väljaarendajaid on mitmeid, kuid silmapaistvamad neist on eelkõige 20. sajandi alguses tegutsenud kunstnikud ja kunstipedagoogid Kristjan Raud ja Ants Laikmaa (vt Summatavet 2010a), hiljem ka Kaljo Põllu, kes kõik suunasid oma ópilasi elavat pärimust uurima ja välitöödel inspiratsiooni koguma (vt nt Põllu 1990, 1999; Summatavet 2010b). Siinkohal nimetagem ka Laikmaa õpilast Oskar Kallist, kelle Kalevipoja-ainelised teosed sündisid inspireerituna välitöödest Eesti külades, kuid kuna kunstnik pole eepose väljaandele terviklikku raamatukujunduse lahendust loonud, siis tema teoseid käesolevas artiklis ei käsitleta.

Võib väita, et see loomemeetod on kõige enam süvenemist ja aega nõudev, sest eeldab pikaajalist pühendumist pärimuse tee- 
madele ning süsteemset eeltööd. "Kalevipoja" illustreerijana iseloomustab seda kõige paremini Kristjan Raud. Näiteks 1936. aastal Eesti Kirjanduse Seltsi poolt välja antud "Kalevipojas” ilmusid Raua joonistused koos Hando Mugasto teostega. Väljaande puhul tuleb märkida, et Mugasto meisterlike ja trükitehniliselt kõrgekvaliteediliste puugravüüride kõrval ei pääse vahelehtedele paigutatud Raua teoste väikesemõõdulised must-valged reproduktsioonid kuidagi mõjule. Selles võib süüdistada väljaandja maitset, kujundusotsuseid ja teatud eeskujusid, sest võrdluseks võib tuua Eesti Kirjanduse Seltsi poolt 1939. aastal välja antud "Kalevala", kus Akseli Gallén-Kallela suuremõõtmeliste Kalevala-maalide must-valgete reproduktsioonide avaldamine on lahendatud samas kujundusvõttes. Mõlema kunstniku detailirohked teosed kaotavad väikeses formaadis algupärase mõju. Alles 1975. aastal välja antud "Kalevipoeg" ilmus suuremõõtmeliste Raua tööde reproduktsioonidega, mida eepose lugejal on huvitav detailselt silmitseda, teoste meeleollu sisse elada ning nende abil oma kujutlusvõimet avardada.

Raua teosed vajavad põhjalikku süvenemist, sest nende loomisele on eelnenud pikk eeltöö. Raud kogus ainelist ja suulist rahvaloomingut, aitas kirjasaatjatelt pärimust koguda ning Eesti Rahva Muuseumi vanavara kogumistoimkonna juhina innustas kunstnikke ja kunstiõpilasi külades ainelist pärandit koguma (vt nt Summatavet 2007, 2010a, 2011). Kunstnik otsis rahvaluule müütilistest teemadest eelkõige inspiratsiooni ning ei kasutanud otseseid eeskujusid või rahvakunsti tsitaate. Kunstiteoreetilistes kirjutistes võrdles ta rahvakunsti professionaalse kunstniku loomeprotsessiga ning märkis, et ühe väikese rahva luule, laulud, muistsed jutud, viisid, vanasõnad on "elu tarkuse tunnistused" ning igatsused tasakaalu, rütmi ja õnne järele (Raud 1913). Ta süvenes müüdi teemadesse, arutles rahvaloomingu rolli ja funktsiooni üle ning oli veendunud, et muinaslood peegeldavad nende loojate üldinimlikke unistusi ja vaimseid väärtusi: "Muinasjuttudes tunneme ennast kui vabad ja rõõmsad lapsed, sest leiame ennast siin imede ja harulduste keskel, kus valitseb siiski teatud kord, mille alusel võidavad õiglus, headus ja ilu. Muistsed viisid kergendavad meie südant iga 
kord kui me neid kuuleme ning need vaimustavad ja puhastavad kuulajat" (Raud 1913).

Raud rõhutas, et luulet ja laulu kuuldes ärkavad inimeses "peenemad elulised funktsioonid", sest "rahva vaimne energia", soovid, tunded, mõtted, ihad ja lootused on koondatud lauludesse: "Kui meie esivanemad laulu lõivad, olivad nad kõige hingega sääl juures. Nende elu oli loomise momentidel nende silma ees ja laul oli lahutamata sellega ühenduses. Laulik võttis nutta ja hõisata lauldes, ja iga kordaja ja kuulaja käis sarnasest tundetulest läbi." Ta kirjutas, et ka mustrid ehk "kirjad" ning rütm on harmoonia ja täiuslikkuse avaldus, mis sünnib intuitiivselt tegija südames ja tunnetes ning "rahustab" mõnutunnet, sest kaunistatud tarbeese on elu "rütmilise käigu" loomulik osa ning hea sõber ja abiline, kellega kõneldakse ning kellest lauldakse kui indiviidist (Raud 1911).

Raud juhtis tähelepanu sellele, et rahvaloomingus leiduvad teemad "lasevad midagi kõrgemat, tundmatut aimata" ning need tunded ja kogemused on pärit paremast ning täiuslikumast maailmast, kust laulikud oma loomingule inspiratsiooni ammutasid (Raud 1911). Kujutlus parema ja täiuslikuma maailma olemasolust ei lubanud tal rahvaluulet pealiskaudselt illustreerida ning ta püüdis süveneda muistsete loojate hingeellu: "Ma tahan kuju anda sellele suurele isesugusele, millega mind muinsus seob, kuid mida ma ikka vaid aiman ja mille kontuurid ei ole kindlad" (Kangro-Pool 1961: 61).

Kolmandana kirjeldatud loomemeetodi - kunstniku välitöö ning uurimis- ja loometöö mõtestatud seostamise puhul kujustab kunstnik "Kalevipoja" lugu laiemalt rahvaloomingule toetudes, taasesitab ning uuendab arhailisi kujutluspilte ning loob vaatajale võimaluse ka oma kujutlusvõimet suunata argielust kõrgematele mõtetele ning rahvaluules peituvatele üldinimlikele sihtidele, pürgimustele ja unistustele. 


\section{Eepos - vaimne sild kodumaaga}

Kolme eelpool kirjeldatud loomemeetodit analüüsides tekib küsimus, kuhu paigutuvad 2011. aastal ilmunud "Kalevipoja" väljaandes avaldatud Gunnar Neeme teosed. Pealiskaudsel vaatlusel mõjuvad need dekoratiivsete, ühemõtteliste ja naivistlike piltidena, kuid tervikteosesse süvenedes, kunstniku käsikirja ning tema erakirjavahetust uurides ilmneb, et Neeme kompositsioonid pole pelgalt eepose illustratsioonid. Neeme kujundatud "Kalevipoeg" on pigem omanäoline terviklik kunstiteos, milles põimuvad nii teine kui ka kolmas loomemeetod, moodustades teiste "Kalevipoega" kujundanud kunstnikega võrreldes hinnalise erandi.

Neeme teoste reproduktsioonidega väljaanne on ilmunud alles hiljuti ning nagu iga omanäolise ja tavatu kunstiteose puhul, vajab vaataja selle mõistmiseks ja mõtestamiseks aega, eriti kuna Austraalias elanud kunstniku teised teosed pole Eesti kunstipublikule tuntud. Artiklit koostades tuli autoril tutvuda kunstniku varasemate teoste, käsikirjade ja erakirjavahetusega. Suureks abiks kujunesid vestlused "Kalevipoja" väljaande peatoimetaja Marin Laagiga. Samuti osutusid tänuväärseks artikli toimetamisprotsessi vältel aset leidnud mõttevahetused. ${ }^{2}$

Neeme illustratsioonidega käsikirja uurides tekkis artikli autoril ka selge seos kunstniku eesti rahvaloomingu alaste teadmiste ning Austraalia põlisrahva arhailiste märgisüsteemide mentaalse müüditasandi ja maagilis-müstilise rituaalse loomingulise kunstiruumiga, mida ta oma "Kalevipojas" on vabalt ning loominguliselt omavahel seostanud ja ühendanud. Neeme läheb sellesse müüdimaailma sisse varasemate visuaalkultuuriliste tõlgenduste kaudu, mis on omakorda tõlgendused varasemast sõnalisest tõlgendusest. Sellise mitmekihilisuse tulemuseks on unenäolisus, mis oma-

2 E-kirjas küsib toimetaja Kadri Tüür, kas Neeme puhul saab ehk rääkida kolmanda loomemeetodi "meta-variandist", sest kunstnik ei saanud teha välitöid pärimusekandjate juures, kuid tegi "välitöid” varasemate tõlgenduste, reprode ja arhiivimaterjalidega ja sünteesis enda jaoks sealt üht-teist olulist (Kadri Tüüri e-kiri autorile, 03.06.2012). 
korda viitab Austraalia aborigeenide dream time-ile. ${ }^{3}$ Kuid selleks, et Neeme loomemeetodi tagamaid täpsemalt avada, on otstarbekas avaldada põgus ülevaade kunstniku erakogu käsikirjalistest materjalidest, mille on Eesti Kirjandusmuuseumile üle andnud Marin Laak.

"Kalevipoja" uue tõlkeväljaande avaldamise idee sündis kunstnikul koostööst ja loomingulisest sõprusest "Kalevipoja" tõlkija Triinu Kartusega (vt Laak 2011: 13). Mare Kõiva sõnul tutvustasid eestlased kodumaa poliitilist olukorda ja ajalugu Austraalia avalikkusele näitustel ja kirjasõnas, igal võimalusel ka massimeedia kaudu ning poliitilise lobbytöö abil (Kõiva 2010: 269), kuid Neeme arvates "on üsna loomulik ja võibolla ka inimlik, et pagulaskond kümnete aastate möödudes võõras ümbruses ja võõra mõju all on kaotanud füüsilise huvi kõige selle vastu mis kunagi oli eesti." Pikaajaline huvi vanema ajaloo, filosoofia ja võrdleva usundiloo vastu oli paguluses elava kunstniku viinud mõttele, et kuigi Eesti muinasaeg on talle alati müstilist mõju avaldanud, siis häirib teda Eesti "peaaegu tahtlik maha salgamine teiste rahvaste ajaloo kõrval. Milles eesti sulatamine ja ignoreeriv mitteeraldamine slaavi supist on niiöelda karvad turri ajanud. Olen jälle ja jälle enese haavatud uhkuse ja lohutuse otstarbel pöördunud tagasi Kalevipoja juurde" (G. Neeme erakogu: Kp-kujut-kunstis, lk 2-5).

Kunstniku eesmärk oli tutvustada Kalevipoja kaudu oma rahvast, kodumaad ja kultuuri, mida Nõukogude okupatsiooni tõttu maailmas ei tuntud. Neeme tegi põhjaliku eeltöö ning sai hea ülevaate ligi 60 kunstniku Kalevipoja-aineliste kujutava ja tarbekunsti teostest perioodil 1830-1961. Ta koostas lühikokkuvõtteid kunstnike töövõtetest ja loomemeetoditest, alustades Georg Friedrich Schlaterist, Friedrich Ludwig von Maydellist, August Weitzenbergist, Tõnis Grenzsteinist, Amandus Adamsonist, Oskar Hoffmannist ning analüüsis teiste hulgas ka Kristjan Raua, Oskar Kallise, Evald Okase, Peeter Ulase ja Eerik Haameri teoseid (G. Neeme erakogu: Kp-kujut-kunstis 1, lk 1-7). Temagi tõi esile Raua kui esimese

3 Autori vastavateemalistele mõtisklustele andis tuge ja kuju Kadri Tüüri e-kiri autorile, 03.06.2012. 
kunstniku, "kes ei illustreerinud vaid lõi kunstilise kompositsiooni Kalevipoja taustal ainetel” (G. Neeme erakogu: Kp-kujut-kunstis, lk 1).

Neeme hinnangul moodustas "eri peatüki" esimese ja teise Vene okupatsiooni ajal loodud Kalevipoja-ainestik ning ta selgitas, et kõigepealt tuleb mõista nende Eesti kunstnike olukorda ja tingimusi, milles nad pidi looma ja töötama, sest "siis saame ka ehk aru, miks üks või teine väljendus viis ja vorm ei ole meile vastuvõetav ning annab venepärase võõra maigu asjale juurde.” Tema hinnangul on ka pagulaskunstnikest paljud kindlasti katsetanud Kalevipoja "aine kallal”, kuid kõik on jäänud vaid raamatuillustratsiooni tasemele (G. Neeme erakogu: Kp-kujut-kunstis, lk 1-2).

Kunstnik soovis, et raamatu kujundus eristuks kõigist teistest raamatutest, tutvustaks Eesti omapära ja samal ajal oleks kunstiliselt huvitav ka laiemale rahvusvahelisele publikule: “[...] meie Kalevipoeg on hoopis erinev raamat, milles õieti peegeldub mitte üksi mälestus minevikust, vaid ka meie esivanemate mõtteilm ja arusaam" (G. Neeme kiri Triinu Kartusele 28.07.2000, lk 12/1). Käsikirja kujunduses soovis ta kasutada eesti rahvapärase käsitöö mustreid (nt vöökirjad, vaibad jne), sest mustrid võimaldavad "mängida lehekülgede kavandamisega" ning "meie rahvamuster looks kaunistava meeleolu” (G. Neeme kiri Triinu Kartusele 15.11.1996, lk 2-3). Kunstnik koostas ja kujundas Kalevipoja käsikirja lehthaaval käsitsi küljendades, et kaalutletult katsetada, kuidas täpselt peaksid asetuma erisugused kujunduselemendid ning loogiliselt paigutuma eesti- ja ingliskeelsed tekstid.

Neeme lähtus väljaandele loodud kompositsioonides eepose teksti värsiridade rütmist, sisust ning tema kujutlusis tekkivatest muistsetest maastikest. Laak rõhutab, et tegu polegi algselt illustratsioonidega raamatule, vaid eepose värsiridade "tõlgetega" pildikeelde (Laak 2011: 13). Professionaalse kunstnikuna püüdis Neeme samastuda müüdi esitaja nägemis- ja kujutamisoskusega. Ta põhjendas, et professionaalne kunst oli külakogukonnas elanud eestlastele uus ja lühiajaline nähtus, mistõttu muster ja sõna kuuluvad rahvalikult rohkem omavahel kokku kui "alles 18. sajandi 
keskpaiku meie rahvale varasemalt tundmatu pildiline joonistus inimesest" (G. Neeme kiri Triinu Kartusele, 15.11.1996, lk 2).

On tähelepanuväärne, et Pallase kunstikoolis õppinud ning II maailmasõja ajal Saksamaale ja seejärel Austraaliasse emigreerunud kunstnik tegi esimesi Kalevipoja-ainelisi katsetusi juba Pallase-päevil, hiljem ka Saksamaal ja Austraalias. Need katsetused piirdusid tema sõnul "tugeva poisi - hiidliku kangelase kujutamisega"

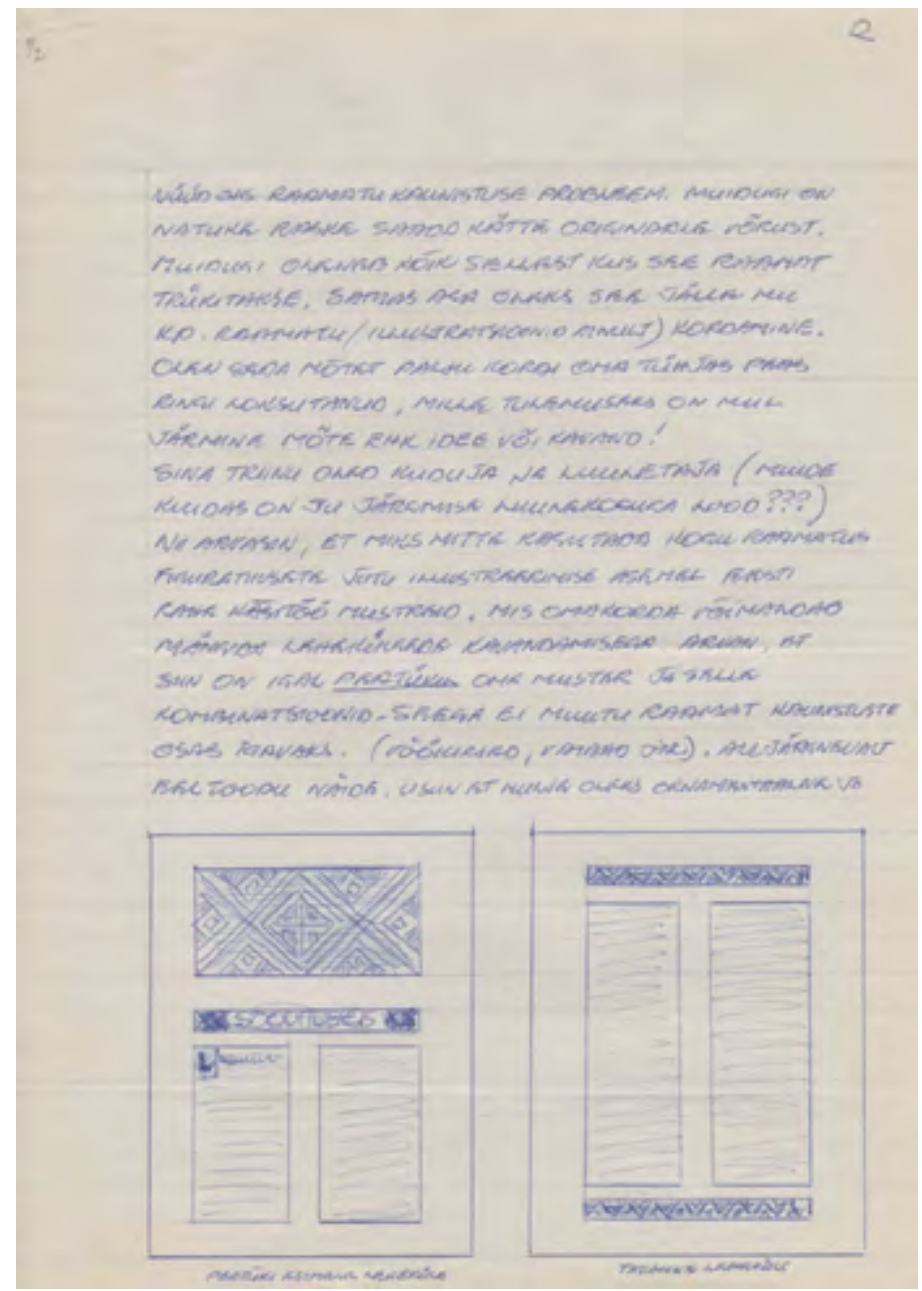

Gunnar Neeme "Kalevipoja” maketi-visandite näiteid: esialgne nägemus kogu teosest. 
ning aja jooksul muutus see üliinimene tema teostes igapäevaseks ja reaalseks inimeseks. Ta kirjutas: "Viimased viis-kuus aastat on aga olnud minus kahtlus, et midagi on viltu - midagi pole nagu õige. Kõik on nagu varemloodu kordamine" (G. Neeme erakogu: Kp-kujut-kunstis, lk 4). Ta soovis leida uusi vaatenurki ja võimalusi, kuidas Kalevipoega kujutada.

Neeme püüdis hoiduda eepose teemade illustreerimisest ning "astuda üks samm edasi": "Ja nii hakkasin ma kaaluma ja sõeluma mõtet, et Kalevipojale lähenemine võiks olla hoopis erinev senistest seisukohtadest. Ja see on eestlases aastatuhandeid asunud alateadvuslik tunne, mis andis põhjuse Kalevipojas esitatud sündmuste kujundamisele: abstraktne sümbolism, alateadvuses pesitsev mana. Kuna ma juba varem mainisin et kogu loos pole tegelikult tegemist mitte ühe inimesega, vaid kogu rahvaga, nii ei esita ma mitte kangelast ja tema tegusid, vaid kogu meie rahvast ja [soovin] luua tunde maailma... st mitte illustreerida, vaid tõlkida" (G. Neeme erakogu: Kp-kujut-kunstis, lk 5).

Pika eeltöö tulemusel otsustas ta, et tuleb "välja tuua "Kalevipoja" vaim, see alateadvusest rahva mõte. Meie tunde maailma. On üsna loomulik, et ühel või teisel juhul pean lisama ka Kalevipoja kui figuuri, kuid see pole "Kalevipoeg" ise, vaid sümboolne määritlus. Senini on seda saavutanud ja teinud ainult Kr. Raud. Tema primitiivselt ürgjõulisus on minule võõras. Teatud momentidel isegi [väga] võõras. Seepärast olen jäänud peatuma nn subconcious halfdream väljendi juurde" (G. Neeme erakogu: Kp-kujut-kunstis, lk 6).

Alateadlikel tunnetus- ja une-aja tasanditel "Kalevipoja" müüditegelikkuse kujutamine äratas kunstnikus meeleolusid, mis olid seotud ka kaugel asuva kodumaaga. Neeme kirjutas Kartusele: "Mis aga puutub "Kalevipoja" piltide kohta, siis pean seda väga tõsiselt arutama. Sest paljud neist ei seleta/kujuta lugusid või sündmusi, vaid tõlgivad pildilikult sündmust, seega rõhutavad pildiliselt meeleolu. Nagu pildid vanast eesti talust, inimestest, jne. samuti ka meie usust, arusaamast ning probleemidest" (G. Neeme kiri Triinu Kartusele 28.07.2000, lk 12/1-2). 

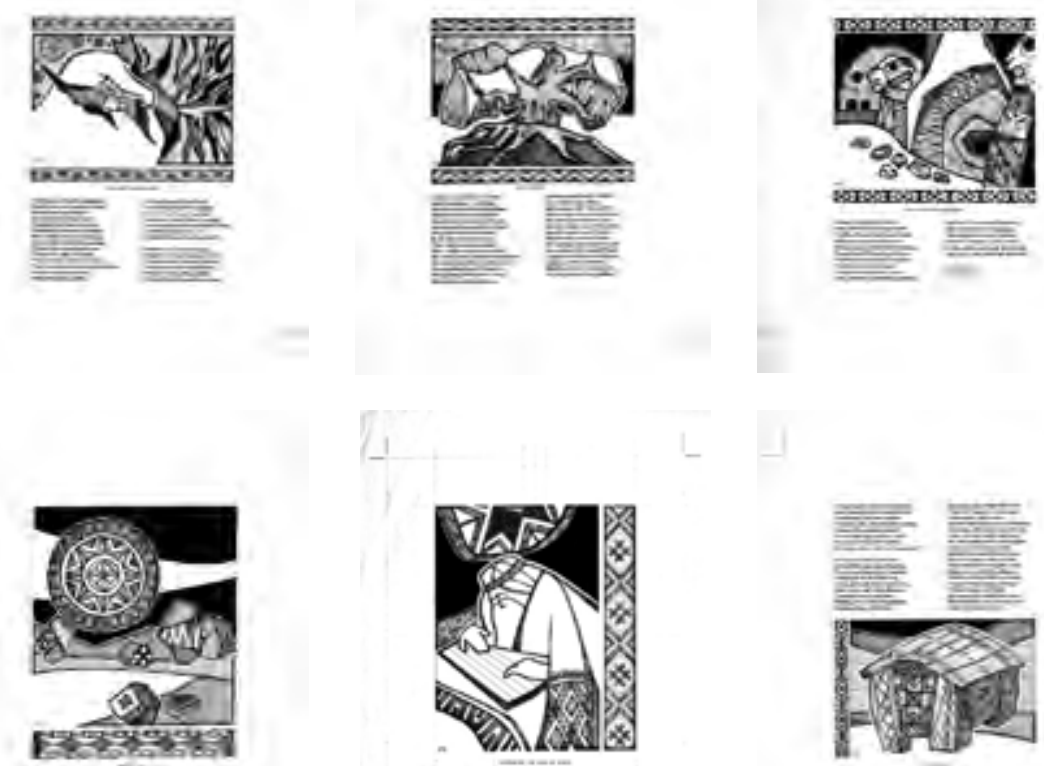

Gunnar Neeme "Kalevipoja" maketi näiteid illustratsioonidega: Tuuslari tapmine, suur tamm, Allilma värav, taevas, Vanemuine, kirst.

Kalevipoja värsiridade lugemisel loodud kompositsioone ja müüdimaastikke kujutades meenusid kunstnikule tema lapsepõlve kodumaa maastikud. Ta kirjutas Kartusele: "Olen kindel, et sinu töö juures, vaatamata tõlke probleemidele, viivad KP lood ja loogika tahtmatult Kodu Eesti radadele. Ja kas pole huvitav, et ka minu väikeses osalemises on Austraalia unustatud. Tulevad meelde päevad maal vanaema või onu juures. Otsekui loeksin neid heina kõrsi ja ajan juttu lehmade ning lammastega ja muidugi koertega. Peajoones aga naudin rehealuse ning küüni hõngu ning metsade salapärast, ent nii omast meeleolu. Eriti veel minule kui linnapoisile. Need on pildid ja tunnetused, millised minus kunagi ei unune ning nüüd siin Austraalias uuesti elama hakkavad" (G. Neeme kiri Triinu Kartusele 28.07.2000, 1k 12/1). Kirjadest selgub, et "Kalevipoja" käsikirja kujundamine andis autorile võimaluse ka unistada 


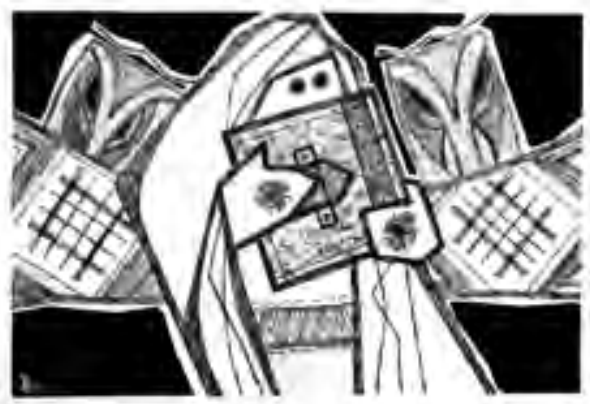

Gunnar Neeme loomingulist kreedot "mitte illustreerida, vaid tõlkida" kandvad pildid märkide ja vöökirjadega (vt Neeme, Kp-kujut-kunstis, lk 5). "Piiga" ja "Tamm".

ning piltlikult väljendades luua vaimne sild kodumaa ja lapsepõlve maastikega.

"Kalevipoja" kompositsioonides positsioneeris kunstnik end muistse lauliku ja mustrilooja kaasaega, püüdes näha ja esitada müuti tolleaegse looja kujutlusvõime ja teadmiste valguses. Neeme loodud figuraalsed kompositsioonid on erineva üldistusastmega, ta on neis teadlikult loobunud professionaalses kunstihariduses omandatud kujutusvõtetest: "Ühte peab kõigejuures arvestama, on see, et tolleaegne inimene nägi ja mõistis uusi ning ebatavalisi sündmusi ja asju teisiti, kui seda teeb isegi tavaline inimene tänapäeval” (G. Neeme kiri Triinu Kartusele 28.08.1997, lk 9/2). Neeme rõhutas, et Kalevipoja lugu on minevikus toimunud sündmustele rajatud mälestused ning meie rahva hinge peegeldused, meie hing ja arusaam (G. Neeme kiri Triinu Kartusele 28.07.2000, lk 12/1). Kunstnik lähtub "Kalevipoja” kujundamisel üldistatud ja ornamenteeritud figuurist kui märgist, sümbolist ja mustrist, püüdes 
"Muinasmaastik" ja

"Muinastaevas".
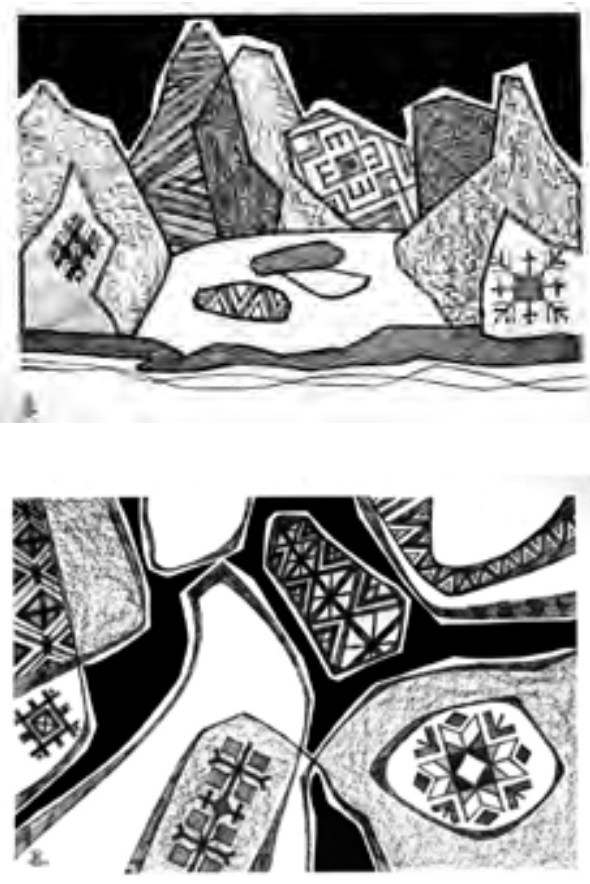

samastuda muistses ja arhailises kunstiruumis või külakogukonnas üles kasvanud loojaga, kes talletab ja esitab oma tundeid ning hinges toimuvaid elamusi ja kogemusi suulise või ainelise rahvaloomingu kaudu.

Tutvudes kunstniku loodud algse "Kalevipoja" käsikirjaga, selgub, et Neeme kujunduskontseptsiooni ning käsikirjalist autoriraamatut, mis on "täiesti erinev kõigist senistest" (G. Neeme kiri Triinu Kartusele, 15.11.1996, lk 2), on eepose 150. juubeliaastal (2011) ilmunud väljaande kujunduse ja trükimaketi autorid põhjalikult muutnud. Neeme käsikirjas on tekstis, päises ja peatükkide vahelehtedel asuvate kompositsioonide ülal, all või külgedel stiliseeritud mustrijoonised, mille otstarvet kunstnik põhjendas järgmiselt: "Igal peatükil peaks olema oma vöökirja või vaiba muster ja selle kombinatsioonid, et raamat ei muutuks igavaks. Usun et mulje oleks ornamentaalne ja puhas" (G. Neeme kiri Triinu Kartusele, 15.11.1996, lk 2). Trükis ilmunud väljaandes need ornamendid aga 

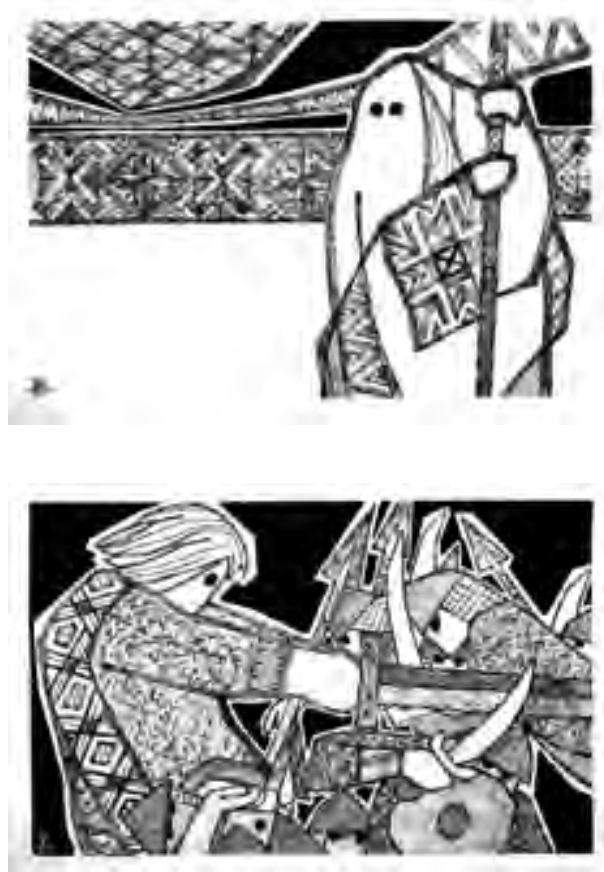

"Vana" ja

"Võitlus".

puuduvad, sest Eesti Kirjandusmuuseumi ning kirjastuse "Kunst" koostöös sündinud kujunduses on Neeme algsest kujundusideest ja sõnumist loobutud.

Siinkohal kerkib küsimus, milliseid väärtuslikke visuaalsel kujul esitatud sõnumeid, elamusi ja tunnetusvälju kaotab kunstniku kujutlusis sündinud "Kalevipoeg" - "tõlge" ja müüdi taasesitus siis, kui autori poolt teadlikult või intuitiivselt valitud loomismeetodi nüanssidest ning kunstiruumi kuuluvast terviklahendusest väljaande avaldamisel loobutakse. Kas kunstniku visioon ja sõnum muutuvad ning moonduvad või püsivad samana? Kas selline moonutatud teos on vaatajale vastuvõetavam ja "tänapäevasem" või on midagi väärtuslikku mentaalsel tasandil kaduma läinud? Miks autori poolt teadlikult loodud tervikteos taandatakse teksti kaunistavate dekoratiivsete illustratsioonide-stilisatsioonide tasemele? Kuidas suure töömahu ja süvenemisastmega loodud tervikteose autor, kelle kunstiline sõnum "tükeldatakse", võiks sellise tulemusega rahul olla? Siinkohal tasub võrdluseks meenutada ka Raua 
mitmetähenduslikku ja sügava tunnetusega loodud teoste kogumit, mis "Kalevipojas" ilmus kunstipubliku kätte samuti fragmentaarsena, illustratsioonide tasemele taandatuna.

\section{Kokkuvõtteks}

Kreutzwaldi "Kalevipojaga" kõrvuti eksisteerib Eesti kunstis mitmeid kunstnike "Kalevipoegi", mille loomisel on teoste autorid lähtunud nii eepose tõlgendustest, tellija-vaataja harjumustest-ootustest, müüdi taasesitusega seotud mõtteeksperimentidest, isiklikest kogemustest või kunsti tunnetusjõu seostest kunstiruumi mitmetasandiliste tähendusväljadega. Kuna kunstnikud tavaliselt ei püüa ega soovi oma kujutlusvõime ja loomeprotsessi tagamaid analüüsida, veel vähem argikeele tasandil sõnastada, saab "Kalevipoja" väljaandeid uurides lähtuda eelkõige Eesti kunstihariduse ja professionaalse kunsti traditsioonidest.

Eepose väljaannetes ilmunud teostes on kunstnikud rahvaloomingu esemelist pärandit ja ornamente uurinud ning kujutanud erisuguse süvenemisastmega ja eri meetodeid kasutades. Tänapäeva kunstnikud, kellel on oma "käekiri" ja loojasõnum, enamasti ei uuri ega mõtesta minevikku, vaid keskenduvad nüüdisaegse inimese hingeelule, ühiskonna probleemidele ning üksikisiku vaevadele, rõõmudele ja muredele. Eepose ja müüdi teemadega kokku puutudes võivad loojad sellegipoolest väärtuslikke teoseid luua ning eepose tõlgendustraditsiooni seniseid piire lõhkudes ja uuendades tõlgendada eepost ka pelgalt lugemiskogemuse põhjal tänapäeva inimese isiklike elamuste, väärtushinnangute ja elukogemuse võtmes. Kuid järgmiste "Kalevipoja" väljaannete kujundamise puhul on oluline ka küsimus, kuidas põimida tänapäeva maailmas elava ja tegutseva kunstniku kujutlusvõimet ning kunstiruumi tunnetuslikke tasandeid müütide algupäraste ja arhailiste tunnetustavadega. 


\section{Allikad}

Kalevipoeg (1999). Eesti Muistendid. Hiiu- ja vägilasmuistendid I. Monumenta Estoniae Antiquae II. EKI folkloristika osakond, EKM Eesti Rahvaluule Arhiiv. Tallinn: Eesti Keele Instituut. Internetis http://www.folklore.ee/rl/folkte/myte/ kalev/failb.html (vaadatud 25.07.2012).

Kreutzwald, Friedrich Reinhold 1936. Kalevipoeg. Tartu: Eesti Kirjanduse Selts. Kreutzwald, Friedrich Reinhold 1946. Kalevipoeg. Tallinn: Ilukirjandus ja Kunst.

Kreutzwald, Friedrich Reinhold 1951. Kalevipoeg. Tallinn: Eesti Riiklik Kirjastus.

Kreutzwald, Friedrich Reinhold 1961. Kalevipoeg. Tallinn: Eesti Riiklik Kirjastus.

Kreutzwald, Friedrich Reinhold 1975. Kalevipoeg. Tallinn: Eesti Raamat.

Kreutzwald, Friedrich Reinhold 2009. Kalevipoeg. Tallinn: SE\&JS.

Kreutzwald, Friedrich Reinhold 2011. Kalevipoeg. Tartu-Tallinn: Eesti Kirjandusmuuseum, Kunst.

\section{Kirjandus}

Annist, August 1936. Viienda trüki saatesõna. - Kreutzwald, Friedrich Reinhold. Kalevipoeg. Tartu: Eesti Kirjanduse Selts, lk 285-290.

Biggs, Michael A. R. 2004. Learning from Experience: approaches to the experiential component of practice-based research. - Forskning, Reflektion, Utveckling. Ed. H. Karlsson. Stockholm: Vetenskapsrådet, Swedish Research Council, pp. 6-21.

$\mathrm{EE}=$ stilisatsioon. - Eesti Entsüklopeedia 8,1995. Tallinn: Eesti Entsüklopeediakirjastus.

ENE = illustratsioon. - Eesti Nõukogude Entsüklopeedia 3, 1988. Tallinn: Valgus. 
Eisen, Matthias Johann 1920. Kalevipoja esi-isad. Teine, täiendatud trükk. Tallinn: Eestimaa Kooliõpetajate Vastastikuse Abiandmise Seltsi Raamatukaupluse Kirjastus.

Eisen, Matthias Johann 1995. Eesti mütoloogia. Tallinn: Mats.

Eliade, Mircea 1974. Shamanism: Archaic Techniques of Ecstasy. Bollingen Series LXXVI, Princeton: Princeton University Press.

Gombrich, E. H. 1997. Kunsti lugu. Tallinn: Avita.

Hoppál, Mihály 2008. Etnosemiootika. Tartu: EKM teaduskirjastus.

Kalm, Mart 2010. Kujundades ja tootes. - Eesti kunsti ajalugu V, 1900-1940. Toim. Mart Kalm. Tallinn: Eesti Kunstiakadeemia Kirjastus, lk 583-602.

Kangro-Pool, Rasmus 1961. Kristjan Raud: 1865-1943. Tallinn: Eesti NSV Kunst.

Kirme, Kaalu 1999. Autoportree silmusega. Adamson-Ericu dokumentaalne eluromaan. Tallinn: Kunst.

Knuuttila, Seppo 2010. Nähdyt ja kuvannetut myytit. Preconcieving and visualizing myths. -Myytti, kuva, mielikuva. Myth, image, idea. Mito, imagen, idea. Kalevala granaína. Toim. Manuel Velés Cea, Annika Waenerberg. Jyväskylä-Granada: Mänty kustannus OY, s. 9-21.

Krull, Hasso 2006. Loomise mõnu ja kiri. Loomingu raamatukogu, 5/6. Tallinn: SA Kultuurileht.

Kuma, Helene 2001. Rahvakunsti traditsioon eesti tarbekunstis. Ajalooline tagasivaade. - Rahvatraditsioonidest eesti kunstis. Viljandi: Viljandi Kultuurikolledž, Talukujunduse ja rahvusliku käsitöö kateeder, Eesti Kunstiakadeemia tekstiilikunsti osakond, lk 21-27.

Kõiva, Mare 2010. Eestlased ja eesti keel Austraalias. - Eestlased ja eesti keel välismaal. Toim. Kristiina Praakli, Jüri Viikberg. Tallinn: Eesti Keele Sihtasutus, $1 \mathrm{k} 265-283$.

Laak, Marin 2011. Saateks. - Kreutzwald, Friedrich Reinhold. Kalevipoeg. The Estonian National Epic. Eesti rahvuseepos. Tartu-Tallinn: Eesti Kirjandusmuuseum, Kunst, lk 12-13.

Lang, Valter 1999. Kultuurimaastikku luues. Essee maastiku religioossest ja sümboliseeritud korraldusest. Eeati Arheoloogia Ajakiri, nr 3/1, lk 63-85. 
Laugaste, Eduard 1951. Järelsõna. - Kalevipoeg. Tallinn: Eesti Riiklik Kirjastus, lk 319-346.

Laugaste, Eduard; Normann, Erna 1959. Muistendid Kalevipojast. Eesti muistendid. Hiiu- ja vägilasmuistendid I. Monumenta Estoniae Antiquae II. Tartu Riiklik Ülikool, Eesti NSV Teaduste Akadeemia, Fr. R. Kreutzwaldi nimeline Kirjandusmuuseum. Tallinn: Eesti Riiklik Kirjastus.

Levin, Mai 2010. Rahvusromantism eesti kunstis. - Eesti kunsti ajalugu V, 1900-1940. Toim. Mart Kalm. Tallinn: Eesti Kunstiakadeemia Kirjastus, lk 97-127.

Lévi-Strauss, Claude 2001. Metsik mõtlemine. Tallinn: Vagabund.

Lotman, Juri 1999. Semiosfäärist. Tallinn: Vagabund.

Lotman, Juri 2001. Kultuur ja plahvatus. Tallinn: Varrak.

Lönnrot, Elias 1939. Kalevala. Tartu: Eesti Kirjanduse Selts.

Niedderer, Kristina; Imani, Yassaman 2008. Developing a Framework for Managing Tacit Knowledge in Research using Knowledge Management Models. - Undisciplined! Proceedings of the Design Research Society Conference 2008. Sheffield: Sheffield Hallam University. Internetis http://shura.shu.ac.uk/507/1/ fulltext.pdf (vaadatud 02.07.2012).

Nirk, Endel 1975. Eesti rahvuseepos "Kalevipoeg". - Kreutzwald, Friedrich Reinhold. Kalevipoeg. Tallinn: Eesti Raamat, lk 263-274.

Nonaka et al. 2000 = Nonaka, Ikujiro; Toyama, Ryoko; Konno, Noboru. SECI, ba, and leadership: a unified model of dynamic knowledge creation. - Long Range Planning, 33: 1, pp. 5-34.

Polanyi, Michael 1962. Personal Knowledge: Towards a Post-Critical Philosophy. Chicago: University of Chicago Press.

Põllu, Kaljo 1990. Tallinna Kunstiülikooli kümme soome-ugri uurimisreisi. Tallinn: Olion.

Põllu, Kaljo 1999. Eesti Kunstiakadeemia kakskümmend soome-ugri uurimisreisi. Tallinn: Olion.

Päts, Voldemar 1928. Riigi Kunsttööstuskooli ópilaste tööd. Tallinn: Riigi Kunsttööstuskool.

Raud, Eno 1961. Kalevipoeg. Tallinn: Eesti Riiklik Kirjastus. 
Raud, Eno 1976. Kalevipoeg. Tallinn: Eesti Raamat.

Raud, Eno 1998. Kalevipoeg. Tallinn: Tiritamm. Internetis http://www.nlib.ee/ html/digi/rmt_ill/autorid/tammsaar_j/tam_kalev.html (vaadatud 14.02.2012).

Raud, Kristjan 1911. Oli ennemuiste nõnda - Eesti Kultura I, lk 351-355.

Raud, Kristjan 1913. Kas kasvame või kaome = Mõtted rahvakunstitööde korjamise puhul. - Eesti Rahva Muuseum, lk 3-5.

Raunam, Oskar 1964. Õppeasutuse rajamise ja arengu ajaloost. - Eesti NSV Riiklik Kunstiinstituut. 50 aastat kunstialast haridust. Tallinn: Eesti NSV Kunst, lk 7-23.

Scrivener, Stephen A. R. 2006. Visual Art Practice Reconsidered: Transformational Practice and the Academy. - The Art of Research. Research Practices in Art and Design. Eds. M. Mäkelä, S. Routarinne. Helsingi: Publication Series of the University of Art and Design Helsinki A 73, pp. 157-179.

Schön, Donald A. 1983. The reflective practitioner: How professionals think in action. New York: Basic books.

Sibrits, Heili 2009. Tegin. Sest tahtsin. - Postimees, 07.11.2009. Internetis http:// pluss.postimees.ee/184870/tegin-sest-tahtsin/ (vaadatud 14.02.2012).

Siikala, Anna-Leena 2002. Mythic Images and Shamanism. A Perspective on Kalevala Poetry. FFC 280. Helsinki: Suomalainen Tiedeakatemia.

Summatavet, Kärt 2007. Mõningaid mõtteid kunstist, Kristjan Rauast ja vanavara kogumisest. - Mäetagused nr 37, lk 7-44.

Summatavet, Kärt 2010a. Rahvaesteetika - nähtavaks kujustatud mõte ja kogemus. - Mäetagused nr 44, lk 7-28.

Summatavet, Kärt 2010b. Myytti ja mielikuvitus. Mythology and artist's imagination. - Myytti, kuva, mielikuva. Myth, image, idea. Mito, imagen, idea. Kalevala granaína. Toim. Manuel Velés Cea, Annika Waenerberg. Jyväskylä-Granada: Mänty kustannus OY, s. 23-37.

Summatavet, Kärt 2011. "Suured müstilised muinaslilled" hinges ja loometöös. - Lee. ERMi Sõprade Seltsi aastaraamat 17. Toim. T. Sikka, S. Madisson, T. Kaalep, lk 34-39.

Sõgel et al. 1953 = Sõgel, E.; Izmestjev, P. N.; Kangilaski, O.; Lepik, M.; Raud, L.; Tobias, H.. Fr. R. Kreutzwald 1803-1882. Elu ja tegevus sõnas ja pildis. Eesti NSV Teaduste Akadeemia Kirjandusmuuseum. Tallinn: Eesti Riiklik Kirjastus. 
Tralla, Johannes 2009. Ilmus uute illustratsioonidega "Kalevipoeg" - ERR, 05.11.2009. Internetis http://uudised.err.ee/index.php?06183677.

Urgart, Oskar 1946. Saateks. - Kreutzwald, Friedrich Reinhold. Kalevipoeg. Tallinn: Ilukirjandus ja Kunst, lk 235-237.

Valk, Ülo 2011. "Kalevipoja” lauliku maailm: loomisest, eeposest ja müüdist. Kreutzwald, Friedrich Reinhold. Kalevipoeg. The Estonian National Epic. Eesti rahvuseepos. Tartu-Tallinn: Eesti Kirjandusmuuseum, Kunst, lk 532-535.

Vélez Cea, Manuel; Waenerberg, Annika 2010. Prologi. Prologue. - Myytti, kuva, mielikuva. Myth, image, idea. Mito, imagen, idea. Kalevala granaina. Toim. Manuel Velés Cea, Annika Waenerberg. Jyväskylä-Granada: Mänty kustannus OY, s. 5-7.

Vélez Cea, Manuel; Waenerberg, Annika 2010. Kalevala granaína. Myyttejä, kuvia ja tulkintoja. Kalevala granaína. Myths, images and interpretations. Mytti, kuva, mielikuva. Myth, image, idea. Mito, imagen, idea. Kalevala granaína. Toim. Manuel Velés Cea, Annika Waenerberg. Jyväskylä-Granada: Mänty kustannus OY, s. 121-178.

Vetemaa, Enn 1985. Kalevipoja mälestused. Tallinn: Eesti Raamat. Internetis http://www.kirmus.ee/Asutus/Arrak2.php (vaadatud 14.02.2012).

\section{Internetiallikad}

Tali, Andres 2003. Iha ja igatsuse instrumendid - Mängi minuga. Internetis http://www.estpak.ee/ atali/instruments/instruments.html (vaadatud 14.02.2012).

Tali, Andres 2004. Iha ja igatsuse instrumendid ...Sick and Tired... Internetis http://www.estpak.ee/ atali/instruments/instruments.html (vaadatud 14.02.2012).

Tali, Andres 2006. 11 stilli/11 stills. Internetis http://www.estpak.ee/ atali/ instruments/stills.html (vaadatud 14.02.2012). 


\section{Käsikirjalised allikad}

G. Neeme käsikiri Friedrich Reinhold Kreutzwaldi "Kalevipoeg”, eesti- ja ingliskeelne tõlge ja kujundus.

G. Neeme käsikiri "Kp-kujut-kunstis 1".

G. Neeme käsikiri "Kp-kujut-kunstis”.

G. Neeme kiri Triinu Kartusele 15.11.1996.

G. Neeme kiri Triinu Kartusele 28.08.1997.

G. Neeme kiri Triinu Kartusele 28.07.2000.

K. Tüüri e-kiri K. Summatavetile 03.06.2012.

\section{Summary}

\section{Artist's Kalevipoeg: the artistic representations of epic and myth from Kristjan Raud to Gunnar Neeme}

The article focuses on the analysis of the artistic works that represent mythical and epical subject matter on the example of the illustrations incluced in the publications of the Estonian national epic "Kalevipoeg". Three methods can be distinguished that different artists have employed in representing the mythical characters and events in the case of different issues of the epic: illustration and stilisation, delivering artistic message, and engaging in a creation story. Epic and myth can be regarded as the results of human imagination. In their artistic interpretation, vernacular and professional art intermingle, as well as addressing global and personal, eternal and temporal themes. The role of an artist as the intermediator in representing the myth and the artist's role as an interpreter of the folklore is addressed, as well as the ethical and aesthetical ques- 
tions that raise in the course of interpretation. The phenomeonon of artistic research is also discussed in association with the artist's aspirations to elaborate the grounds for his interpretation.

Key words: Myth, epic, art, Kalevipoeg, method of creation, phantasy, inspiration, representations of a myth 


\section{Gnoomid, kooboldid ja goblinid. \\ Uskumusolendite nimetuste tõlkimise spetsiifikast}

Reet Hiiemäe

doi:10.7592/PS/28-2hiiemae

Teesid: Artikkel annab ülevaate uskumusolendite nimetuste tõlkimisel ilmnevatest probleemidest, näiteks kuidas toimida siis, kui sõna keeleline või usundiline vaste sihtkultuuris puudub või kui sellel on sihtkeeles lähtekeelega sarnane kirjapilt, kuid erinev sisu. Peamurdmist valmistavad olukorrad, kui ühes keeles on teatud olendite jaoks detailsem klassifikatsioon kui teises, samuti juhtumid, kui osa olendinimetusest on tõlgitav, kuid osa mitte, või kui mingi termin on lähtekeeles paralleelselt kasutusel nii üldnimetuse kui originaalnimena. Tõlkeraskusi esineb polüteistliku ja monoteistliku usundi maailmapildi erinevuste pinnal, samuti soolisuse edasiandmisel. Eksimuste vältimiseks on vajalik tunda nii vastava sõna päritolukultuuri kui seoseid sihtkultuuriga, samuti olla teadlik kasutuskontekstist. Lisaks on huvipakkuv olendinimetuste tõlgete roll inimeste empiiriliste kogemuste ja nende kirjelduste vormimisel.

Märksõnad: tõlkimine, usund, üleloomulikud olendid, empiiriline kogemus, kultuuriline kontekst

\section{Sissejuhatus}

Olulisi tõukejõude uskumusolenditega seotud terminoloogia üle järelemõtlemisel oli mulle Austria professori Leander Petzoldti raamatu "Väike deemonite ja vaimolendite leksikon" tõlkimine eesti keelde ja kommentaaridega varustamine. Selle ja teiste usun- 
dialaste tõlgetega seoses sai üha selgemaks, et kultuurilise tausta tundmine pole oluline mitte ainult teiste kultuuride oluliste ilukirjandus- ja pärimustekstide (nt eeposte) tõlkimisel, vaid isegi ainult ühe sõna (nt mütoloogilise olendi või kultuseseme nimetuse) tõlkimisel võib osutuda vajalikuks tunda nii selle päritolukultuuri kui seoseid sihtkultuuriga ehk vastavat tähendusvälja laiemalt, olgugi et ka sihtkeele vaste koosneb sageli sisuliselt ainult ühest sõnast. Artikkel annab ülevaate mitmetest uskumusolendite nimetuste tõlkimisel esilekerkivatest probleemkohtadest, kusjuures selgub, et dilemmasid esineb nii laialt tuntud olendinimetuste, nagu nõid, päkapikk, majavaim, kui ka spetsiifilisemate ja lokaalsemalt tuntud usundiliste terminite, nagu $d r u d$, goblin, tõlkimisel. Nii mõnedki tõlkenäited on toodud ülalmainitud vaimolendite leksikonist, kuid puudutatakse ka teisi keele- ja kultuuripaare. Kuid artikkel ei püüa pakkuda universaalseid valmislahendusi, vaid eelkõige juhtida tähelepanu erinevatele võimalustele komistuskivide ületamisel.

\section{Uskumusolendeid puudutava (tõlke)sõnavara aktuaalsus ja mõju maailmakirjeldamise viisidele}

Kanooniliste religioonide tähtsuse taandudes ja seoses ebakindlustundega tuleviku suhtes on nii Eestis kui üldse Euroopas ja mujal arenenud riikides inimeste huvi usundite ja usundiderivaatide vastu viimastel kümnenditel jätkuvalt suurenenud. Märkimisväärne on nende inimeste hulk, kes tunnevad end isiklikult kogevat kontakte vaimumaailmaga, nagu poltergeistide, luupainajate, kummituste, kaitseinglite või kuradiga, kusjuures kohatavate olendite spekter on kultuurilise globaliseerumise käigus muutunud järjest mitmekesisemaks. Näiteks on suuresti just viimaste aastakümnete vastavasisuliste tõlgete teene see, et inimesed on hakanud tõlgendama energianappust energiavampiiride kätetööna või kirjeldama oma meditatsioonikogemust kui kohtumist mõne daakini või šaktiga. 2011. aasta detsembris kutsuti muuhulgas soovijaid jõulumeditatsioonile ükssarvikutega. 
Samuti on tõlgete mõjul muutunud vaimolendite poole pöördumise laad: kui traditsiooniliselt suheldi nendega pigem palve või loitsu teel, siis mitmed viimaste aastate tõlkeraamatud ja nende mõjul ka esoteerilised õpetajad soovitavad esitada kas universumile või vastavale olendile taotlusi (nt Krayoni raamatud ${ }^{4}$ ). Niisiis võib öelda, et lisaks sellele, et tõlkimine mõjustab keelt ja kultuuri - mida on sedastanud paljud tõlketeoreetikud -, mõjustab see ka üksikisiku empiirilist kogemust.

Tõlked ja eestindused katsetavad kultuuri assimileerimis- ja omaksvõtmisvõimet ja selle piire, näiteks on üldkasutatavaks saanud neologismid jeti ja voodoo, zombi ja humanoid, kuigi otsest Eesti kultuuri analoogi, millele tugineda, neil pole. Mõne mõiste omaksvõtuks võib kuluda aastaid, mõni jääbki eksisteerima paralleelselt sihtkultuuri vanemas kihistuses tuntud kujutelmadega (nt Eesti vana veevaimukujutelm versus laenuline Melusine), kuid on ka selliseid, mis ei saavuta haakumist sihtkultuuri mentaalse maailmaga ja jäetakse kõrvale.

Info- ja kultuurivahetus toimub mõlemasuunaliselt: järjest suureneb eesti unikaalse rahvapärimuse tutvustamine väljaspool eesti keeleruumi, samas tõlgitakse eesti keelde arvukalt mütoloogia ja pseudomütoloogia alaseid väljaandeid teistest keeltest. Populaarsete fantastika valdkonda kuuluvate teoste (eesotsas "Harry Potteri", "Kääbiku” ja "Sõrmuste isandaga") juured on rahvapärimuses ning paljude olendite prototüübid ja maagiavõtted vanemast usundist laenatud ja adapteeritud. Populaarne on valdkonna mänguline kasutus, juba aastaid tegutsevad uskumus- ja fantaasiaolenditel põhinevate rollimängudega tegelevad kildkonnad(nt fantastikahuviliste portaal http://www.dragon.ee, Tolkieni-huviliste veebileht http://www.keskmaa.ee). Samuti leidub olendeid puudutavaid rubriike ulmelistides, -blogides, -foorumites (nt ulmehuviliste meililistis sf2001; viimasel ajal www.ulme.ee) ja esoteerikafoorumites, kus võib muuhulgas kohata tuliseid terminoloogilisi, tõlke- ja tõlgendamisteemalisi vaidlusi (nt kas olend, kellega inimene kohtus,

4 Vt http://www.hot.ee/emfestonia/Kontakt_1.6.html (vaadatud 12.09.12) 
oli painaja, inimese enda vaimuteisik, pahatahtlik tulnukas või energiavampiir).

Ka tänapäeva filmikunst otsib sageli inspiratsiooni mütoloogilisest maailmast, õudusfilmides kohtame moderniseeritud, kuid äratuntavalt traditsiooniliste sugemetega monstrumeid, kummitusolendeid, koletisi, deemonlikke alter egosid jms. Fantaasiafilmide ja -kirjanduse puhul kasutatakse fantaasiaolendite loomisel pärimusolendeid teadlikult enamasti ainult algmaterjalina. Samuti ei taotleta tingimata terminoloogilist korrektsust. Ometi kerkivad materjali teistesse keeltesse tõlkimisel siingi üles samad küsimused nagu traditsiooniliste olendinimetuste puhul, mistõttu oleks sellegi valdkonna puhul orienteerumine traditsioonilises usunditerminoloogias teretulnud.

Oma roll on mütoloogilistel olenditel ja nende nimetustel turismitööstuses, kuna turistide jaoks kujundatakse sageli mõnest atraktiivsest usundilisest figuurist rahva või maa visiitkaart. Nii esitlevad meile reisikorraldajate reklaamiprospektid Norrat kui trollide maad, Kreekat seostatakse antiikjumalatega, Paani ja nümfidega, keltide kultuuriloost rääkides meenub kuningas Artur (Artus) ja tema õukond, aga ka lohed ja jumalused jne. Piirkondade turismibuklettides mainitakse majades ja lossides ringi käivaid kummitusi (nt Haapsalu lossi Valge Daam, Tallinna Harju värava kummitus, Tartu kirjandusmuuseumi Lilla Daam jne).

Samal ajal on Eestis otseselt usundi- ja mütoloogiaolenditega seonduvat terminoloogiat käsitlevaid sõnastikke ja leksikone võrdlemisi napilt. Vajadus saada ühtsem pilt nende tihti juba olemuselt ambivalentsete ja keeruka päritolu- ja levikulooga uskumusolendite paljususes on aga olemas. Selles osas pakkusid võrdlusena positiivse üllatuse mõningate Euroopa maade usundihuviliste ringkondade algatused - olendidefinitsioone otsides leidsin juba mõned aastad tagasi rea temaatilisi, sageli muljetavaldava kujundusega, kuid sisult asjatundlikke veebilehti (nt saksa keeles http:// www.daemonen.de; http://www.geisterarchiv.de; http://www. enctype.de/Daemonen/frame.htm; inglise keeles http://www.eaudrey.com/myth), mis annavad vastava olendi definitsiooni või kirjel- 
duse, selgitavad nimetuse päritolu ja heal juhul pakuvad ka vasteid teistes keeltes.

\section{Uskumusolenditega seotud terminoloogia tõlkespetsiifikast}

Peeter Toropi sedastus, mille kohaselt tõlkija ei pea olema mitte niivõrd lingvist kui kulturoloog ning tähtsamaks kui keele tundmine võib osutuda kultuuri tundmine (Torop 2003), kehtib usundinähtuste tõlkimisel eriti, kusjuures lisaks lähte- ja sihtkeelele peab sellise materjali tõlkija tundma ka muid kommunikatiivseid komponente: vastavate kultuuride sümboleid, tabusid, koodkäitumist jms. Ühtlasi tuleb jälgida, et ühte kultuuri ei tõlgitaks teiseks kultuuriks, vaid kultuur peaks jääma ikka samaks, kuid teises keeles mõistetavaks. Siiski määravad just tõlkija rohkem või vähem teadlikud valikud selle, kas tema tõlke põhisuund on pigem võõrapärastav ehk lähtekultuuri- ja keelt rõhutav või kodustav-mugandav ehk sihtkultuurile ja -keelele keskenduv. Saksa filosoof Friedrich Schleiermacher märkis juba oma 1813. aastal ilmunud tõlkemeetodeid kirjeldavas käsitluses, et tõlkijal on piltlikult öeldes kaks valikut: kas viia lugeja originaalmaterjali juurde või originaalmaterjal lugeja juurde (Schleiermacher 1813).

Loomulikult on tõlke puhul oluline selle sihtrühm (nt täiskasvanud tavalugejad, lapsed) ja funktsioon (nt teaduslik, meelelahutuslik, õhustiku edasiandmisele suunatud). Tõlkides olendinimetusi folkloristide jaoks on vaja enamasti vähem lahtiseletamist, definitsioone ja joonealuseid märkusi kui laiemale lugejaskonnale mõeldud tekstis. Näiteks on tavalugejale mõeldud haldjaid tutvustavas raamatus pakutud ingliskeelse sõna dryad tõlkena drüaad (puunümf) (Marriott 2009). Kui tõlke adressaat oleks usundiuurija, oleks tõenäoliselt piisanud ka ainult sõnast drüaad. Seevastu lastele mõeldud tõlgetes on enam põhjendatud kodustav-adapteeriv, võimalikult eestipärasele sõnakasutusele orienteeritud tõlkemeetod. Lisaks on tõlkimise puhul oluline arvestada, kas mingi termin 
paikneb selgitavas kontekstis või moodustab pelgalt osa paarisõnalisest kõnekujundist või vahemärkusest.

Näide:

Painaja (saksa k Alb, Alp, Elphialtes). Saksakeelne painaja nimetus 'Alb, Alp' on tuletatud anglosaksi ja alamsaksa sõnast alf, elf 'haldjas', märkides algselt anglosaksi ja Vana-Skandinaavia pärimusemütoloogilisi haldjaid. Painaja nimetuse alla on rahvausundis koondunud väga erinevad kujutelmad, mis peegelduvad ka regionaalsete nimetuste paljususes. Algselt sõbralikust olendist arenes juba varakult salakaval rõhujaolend, keda piirkonniti tuntakse kõige erinevamate nimetuste all: Hessenis, Frangimaal, Tüüringis, Saksimaal 'Alb', Baieri-Austria alal Trut, ${ }^{\star}$ drud, alamsaksa keelealal ${ }^{\star}$ mahr, Svaabimaal ja Alemanni piirkonnas ${ }^{\star}$ schratt ja Ida-Friisi ja Oldenburgi kultuuriruumis Walrider... (lühendatult raamatust: Petzoldt, Hiiemäe 2010)

- dich hat der Nachtalb geritten

(Saksa rahvapärane ütlus)

- $\quad$ käib peale kui painaja; nagu luupaine käib selga

(Eesti rahvapärased ütlused)

Nagu enamiku muugi materjali tõlkimisel, tuleb ka usundiliste nähtuste puhul olla teadlik tõlkimise mitmemõõtmelisusest, mille puhul olulisemad on:

sünkroonne mõõde (tõlkimine sama piirkonna mitme kultuuri vahel või geograafiliselt eri paikades asuvate kultuuride vahel) ja diakroonne mõõde (tõlkimine varasemast ajast hilisemasse).

\section{Näide:}

$\mathrm{Mu}$ eelkooliealised lapsed leidsid vanaema juurest lambarauad ja küsisid, mis need on. Vastus ei saa piirduda ühe sõnaga, vaid peab hõlmama ülevaate vana aja rõivastumistavadest, rõivaste valmistamise viisidest, nende seostest lambapidamisega, heal juhul ka täienduse, et lambaraudadele (nagu muudelegi metallesemetele) 
omistati usundis pahatahtlike üleloomulike olendite eest kaitsvat tähendust, siit aga johtub juba vajadus täpsustada, kes olid need kurjad olendid, kuidas neid nimetati jne. Lõpuks on vajalik veel piiritlev märkus, et multifilmist nähtud rebaserauad on funktsioonilt teistsugused kui lambarauad, kuigi mõlemad sõnad kõlavad eesti keeles samamoodi.

Seega muutub eri ajastutel ka ühe keele ja kultuuri piires sama sõna tähendusspekter. Ühes ajastus aprioorsed kujundid võivad olla teises mõistetamatu eksootika ja vajada tõlkimist. Teisalt pole ka sünkroonne mõõde konstantne suurus - mõned võõra eksootilise kultuuri terminid ja terved terminikompleksid võivad ajapikku sihtkultuuris kodustuda ja igapäevaseks muutuda. Samuti nagu rahvapärimuses on ka sõnavara puhul olemas kasutamise aktiivne ja passiivne faas. Passiivses faasis võidakse veel teada, mida mingi sõna tähendab, aga seda mitte enam kasutada. Esineb olukordi, kus juba teatakse, mida mingi võõrast kultuurist laenatud termin tähendab, kuid selle sisenemine üldisesse aktiivsesse keelekasutusse võib toimuda tunduvalt hiljem.

Samasugust ühest ajastust või kultuurist teise tõlkimise funktsiooni täidavad näiteks muuseumid (muuseumitõlke kohta vt nt Sturge [2012]), kusjuures tõlge võib külastaja jaoks määrata eseme mentaalse ja vahel ka rahalise väärtuse. Näiteks ilma selgitava tekstita oleks unikaalne meteoriiditükk lihtsalt üks silmatorkamatu kivi, alles teadlikkus selle erakordsusest annab külastajale selle tähenduslikkuse tajumisel uued raamid.

Kirjeldatud näidetega seoses on asjakohane märkida tõlkeobjektide jagunemist mentaalseteks ja esemelis-kujutiselisteks. Kui lambaraudade või meteoriiditüki puhul saab tõlget toetada pildiline või esemeline kujutis, siis olendite kohta fotosid üldjuhul pole. Mõningate olendite kohta on küll olemas vastava kultuuri usunditraditsiooni mõjutustega joonistusi ja maale, kuid need on lõppkokkuvõttes siiski üksikautorite subjektiivsed tõlgendused.

Siin jõuame välja mitmete kultuuriteoreetikute seisukohani, et kogu kultuuri tuleks tegelikult mõtestada tõlkeprotsessina, näiteks lingvist ja antropoloog Michael Agar leiab, et kultuur tervikuna on juba ise konstruktsioon, tõlge allika ja tulemi vahel (Agar 2006: 
5-6). Peeter Torop (2011: 193) märgib, et tõlge ja kultuur on loomuldasa kokkukuuluv mõistepaar - tõlge on kultuuriline ja kultuur tõlkeline nähtus.

\section{Uskumusolenditega seotud terminoloogia ajaloost}

Varasematel aegadel on ilmunud Eestis vähe selliseid käsitlusi, mis kõrvutaksid usundi- ja mütoloogiaolendite erikeelseid nimetusi ja/ või definitsioone.

Uskumusolendite terminoloogia valdkonnas on üks esimesi leksikonilaadseid ülevaateid F. J. Wiedemanni (1876) "Aus dem innerem und äusseren Leben der Ehsten”, mis sisaldab üsna põhjaliku peatüki uskumusolenditest koos definitsioonide ja eesti-saksa tõlgetega. Mitmed eestikeelsed terminid on Wiedemann lahti seletanud kirjelduse kaudu, ilma vastet välja pakkumata, nagu näiteks: "Kratt (schwed. skratt), krätt, raha-rett ist ein Geist oder Kobold, welcher seinen Besitzer an Uebelthätern rächt und ihm Glück und Wohlstand bringt...” [Kratt (rootsi k skratt), krätt, raha-rett on vaim või koobold, kes enda omaniku eest pahategijale kätte maksab ning omanikule õnne ja rikkust toob] (Wiedemann 1867: 427). Wiedemannil esineb küll ka mõningaid põhimõttelisi vigu, näiteks väidab ta, et: "Lendva (der Fliegende, Drache) oder vedaja (der Schlepper) mögen vielleicht nur andere Namen für den kratt sein" [Lendva või vedaja on ehk lihtsalt teised nimetused krati kohta] (Wiedemann 1867: 428). Tegelikult on lendva kui projektiilhaiguse olemus varavedaja omast siiski kardinaalselt erinev, kui välja arvata see, et mõlemad tekitavad kahju enda omaniku teenistuses ja käsul. Samuti ei tee Wiedemann vahet kirjanduslikku päritolu pseudomütoloogia ja rahvaehtsa mütoloogia olenditel.

Olulist lisainformatsiooni vanemate käibel olnud rahvapäraste usunditerminite kohta annab S. H. Vestringi väga rahvalähedane, teistest omaaegsetest tunduvalt mahukam sõnaraamat "Lexicon Esthonico Germanicum”, mille Vestring koostas 18. sajandi teisel 
ja kolmandal aastakümnel ning mis muuhulgas sisaldab ka olulisi usundilisi termineid, nt Härja Pölwe-Rahwas - Zwerge; Kol - Der Popantz, Lendwa Maddo - Der Drache, Liwa Annus - Der Tod, Näk - Ein Wasser Gespenst Sirene. Viimase vaste puhul tuleb siiski märkida, et Kreeka mütoloogiast lähtuval ja hiljem ka Euroopa romantilises kirjanduses meelsasti kasutamist leidnud terminil Sirene on eesti näkiga ainult üsna kauge analoogiaseos.

Oluline nii uskumusolendite kui nendega seostuva terminoloogia kirjeldaja ja võrdlejana oli Oskar Loorits (1900-1961), tema uurimistöö põhjalikumaid väljundeid on monumentaalne saksakeelne teos "Grundzüge des estnischen Volksglaubens" (19491957). Lisaks paljudele muudele defineerib ja võrdleb Loorits selliseid termineid, nagu näiteks Zieher ja Feuerschwanz < kratt, varavedaja; Schutzgeist < kaitsevaim; Alp < luupainaja jpt. Looritsa omapära on julgete sõnasõnaliste tõlgete tegemine, mille sisu jääb nii mõnigi kord lähtekeele lugejale segaseks, nt kadunuke < Verschwundene; tuulispask < Windkot; vanapagan < alter Heide. Märkimisväärne on Looritsa puhul sõna Dämon liigtarvitamine vastena eesti neutraalsemale terminile vaim või haldjas, samuti esineb muidu ettevaatamatuid tõlkeid, nt märgib Loorits, et ihnetest ja ülbetest inimestest saavad majakooboldid (Hauskobold), kes viskavad toidu- ja pesunõusid ümber, lõhuvad ja kolistavad (Loorits 1957: 168). Kirjelduse järgi on tegemist siiski hauast käiva kodukäijaga, mitte majas püsivalt elava majavaimuga, kelle kohta germaani kultuuriruumis kasutatakse sõna Kobold.

1925. aastal ilmunud I. Mannineni "Etnograafiline sõnastik" (Manninen 1925, uustrükid 1979 ja 1993) oli teadusmaastikul tähelepanuväärne selle poolest, et pani aluse etnograafilisele terminoloogiale Eestis. Uuemal ajal ilmunutest väärib märkimist "Eesti rahvakultuuri leksikon", mis sisaldab viiekeelset temaatilist sõnastikku (Viires 1995), kuid on samuti esmajoones pühendatud ainelise kultuurivara terminitele, puudutades põgusalt vaid mõndakümmend uskumusolendit, nagu: dummer Teufel < vanapagan; Erdgeist < maajumal; Erdmutter < murueit; Gespenst < kummitus, tont jne. Neidki olendivasteid kriitiliselt analüüsides tekib küsimus, kas murueit kui romantilise tõlkekirjanduse pitseriga sõna poleks 
parem asendada eesti usundile omasema maaemaga ja maajumal hierarhilises mõttes vähem pretensioonika sõnaga maavaim. Mõnede üksikolendeid puudutavate uurimistööde raames on vaadeldud ka käsitletava olendi nimetuse etümoloogiat ja paralleele teistes keeltes, kuid need piirduvad kitsalt käsitletavat teemat puudutava olenditerminoloogiaga (nt maa-alused - Hiiemäe, M. 2003; näkk, veevaimud - Eisen 1922).

\section{Tõlkimisel esile kerkinud probleemkohti}

\section{Tõlkepiirid}

Torop (2011: 157) märgib tõlkepiiridest rääkides, et vahet tuleb teha kahe piiri vahel: "piir tõlke ja originaali vahel ning piir tõlke ja vastuvõtva kultuuri vahel” - seega ühelt poolt, kas sõna on tõlgitav ehk kas sõna sisu edasiandev vaste on olemas, ja teisalt, kas vaste on sihtkultuuris mõistetav. Rahvausundi kontekstis ei tohi unustada, et sarnaste motiivide, tunnuste või olendihierarhiate olemasolu eri kultuuriruumides ei tähenda, et uskumuste või uskumusolenditega seotud kujutelmade vahel võiks tingimata eeldada geneetilist seost. Isegi kui selline seos on olemas, pole näiteks eesti päkapikk sama, mis on germaani Zwerg, samuti pole meie jõuluvana sama mis Santa Claus või Father Christmas. Päkapikk on Eesti kultuuriruumis uustulnukas, üle võetud kirjanduse kaudu teiste maade gnoomide ja kääbusolendite mõjul (nt juba Kreutzwaldi muinasjuttudes (esmatrükk 1866) figureerivad muude saksa kultuurist kohandatud motiivide hulgas laenuliste sugemetega härjapõlvlased). Ühe mõne aasta taguse jõuluaegse ajalehe järgi aga toovad lastele sussi sisse kingitusi nimelt "heatahtlikud gnoomid" - taas üks näide tõlkepiiridesse kergekäeliselt suhtuvast tõlketegevusest.

Leidub teisigi pealtnäha väga sarnaseid uskumusolendeid, kuid siiski ei ole näiteks Eesti näkk sama, mis Inglise veevaim. Erinevalt Eesti valdavalt magevees tegutsevast uputajaolendist ilmub Inglismaal veevaim pigem merest ja tal on esmajoones tormi eest hoiataja funktsioon, alles teisene funktsioon on olla deemonlik uputaja. Siia 
võib paralleelina tuua veel kolmanda kategooria, mis on edasiarendamist leidnud peamiselt saksa romantilises kirjanduses, nimelt ahvatlevad neidised, nagu Melusine ja Lorelei, kes meelitavad vette ja lõppkokkuvõttes samuti uputavad kergeuskliku inimese, kuid kes kindlasti pole pärisasukad eesti usundis, kuigi tõlkeraamatuna on Melusine-lugu ka Eestis ilmunud. ${ }^{5}$ Kultuuritausta arvestamata üksühene nimetuste ülekandmine oleks kas lausa eksitav või vähemalt riskantne ettevõtmine. Kuigi mitmete eesti uskumusolendite puhul võib oletada germaani mõjutusi, ei saa neid käsitleda automaatselt kui germaani laene, nagu seda usundiuurija Oskar Loorits sageli on teinud.

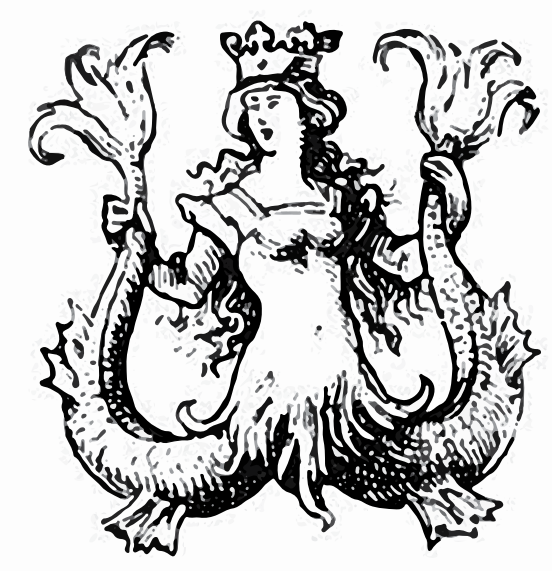

Melusine

2. Polüteistliku ja monoteistliku maailmapildi kokkupuutel tekkivad tõlkeraskused.

Eesti kaitsevaimude saksakeelse vastena on eriti vanemates tõlgetes kasutatud sõna Gott. Näiteks Wiedemann (1876) pakub välja tõlkekombinatsiooni: Kodujumal - Hausgott. Rahvakultuuri leksikon (Viires 1995) toob ära seose: Erdgeist < maajumal. Kuid eesti usundi kõrgajal polnud ainujumala idee uskumusolendite süs-

5 Hofmann, Heinrich; Osterwald, Wilhelm; Mägi, Otto. Ilus Melusine. Jurjev 1898. 
teemi kuigivõrd üle võetud ning nii ülaltoodud kodujumala kui maajumala puhul oleks tegelikult põhjust rääkida piirkondlikest kaitsevaimudest ja mõttekas hoiduda eksitavast sõnast jumal, mis germaani kultuuriruumis seostub siiski esmajoones monoteistliku taevajumala kujutelmaga. Ilmeka näite selle kohta, kuidas mingi tõlkevaste hakkab ühest teosest teise kandudes vohama ja võib luua väärpildi tegelikkusest, saab tuua omaaegsest esinduslikust monumentaalteosest "Handwörterbuch des deutschen Aberglaubens", milles tsiteeritakse ühe M. J. Eiseni töö saksakeelset tõlget ja märgitakse: "Die Esten haben Tõnn gar zum Schweinegott gemacht"6 (HDA I: 505). Tegelikkuses on jutt pühak Antoniusega seoses olevast Tõnnist, kes on eesti usundis täitnud ainujumalaga võrreldes üsna tagasihoidlikku sigade kaitsevaimu funktsiooni.

Üks olulisi erinevusi on asjaolu, et eesti usundilised olendid on üldiselt vähem demoniseerunud kui Kesk- ja Lääne-Euroopa piirkonnas (nt Saksamaa, Itaalia, Austria, ka Rootsi) esinevad. On tõsi, et ka Eestis hakkasid muidu neutraalsed või isegi heatahtlikud vaimolendid ristiusu mõju suurenedes samuti vähehaaval demoniseeruma, kuid siiski tagasihoidlikumal määral kui nimetatud piirkondades üldiselt, põhjuseks nii keelebarjäär jumalasõna levitamisel kui Eesti geograafiliselt perifeerne paiknemine, mistõttu pole duaalne jaotus eesti usundi olendkonnas üldjuhul nii kontrastne. Seega osutub siin tõlkimisel arvestamist vajavaks kultuuriliseks komponendiks psühholoogiline aspekt, nimelt hirmu faktor - ühes kultuuris seostub sama olendiga numinoosne hirm, teises mitte.

Eelnimetatud põhjustel ei ole eesti kontekstis sageli põhjendatud ka deemoni mõiste kasutamine viimase negatiivse konnotatsiooni tõttu, pigem sobib neutraalsem sõna vaimolend, vaim. Kindlasti on terminid deemon ja vaimolend osaliselt kattuvad, ehk täpsemalt vaimolendid on katusmõiste, mis hõlmab muuhulgas ka deemoneid, kuid selle alla kuuluvad laiemalt nii negatiivsed kui positiivsed, pahatahtlikud kui heatahtlikud olendid. Niisiis on põhjust olla ettevaatlik ja mitte mehhaaniliselt asendada ühe kultuuri märke

6 Eestlased on Tõnnist lausa sigadejumala teinud. 
teise omadega (vrd Torop 2003). Kui saksa usundi kontekstis on täiesti aktsepteeritav rääkida olenditest nimega Korndämonen, siis nende eesti suguvendade puhul oleks vaste viljadeemon kasutamine ebatäpne, asjakohasem oleks viljavaim või mõningatel juhtudel viljahaldjas. Samas tuleb jälgida iga konkreetset juhtu eraldi, näiteks sõna Gespenst vasteks sobib nii kummitus kui tont. Arvestades usundilist sisu on kummitus täpsem vaste. Skandinaavia laensõna tont (soome $\mathrm{k}$ tonttu, rootsi $\mathrm{k}$ tomte) on Eestis piirkondlikult tuntud ja selle taga peituv olend on olemuselt deemonlikum, sarnane-

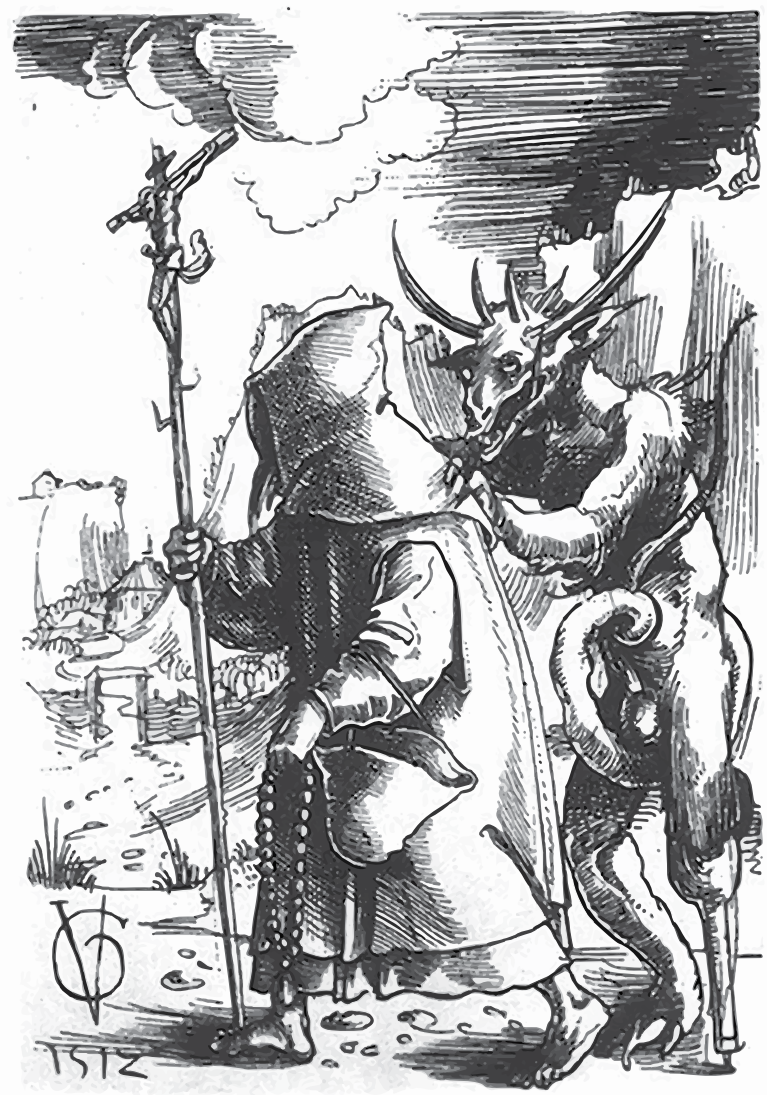

Vanemas euroopa kultuuris kujutati kuradit üldiselt hirmutava ja inimeste käitumist distsiplineerivana. Kurat kimbutab munka. Sulejoonistus. 1512. 
des enam kuradiga (tont, vanatont on ka üks kuradi eufemisme), Virumaa tekstides esineb tont lisaks veel ka varavedaja rollis. Seega võib tont sobida valitud kontekstides eriti pahatahtlikult käituva kummitusolendi tõlkevasteks. Samuti pean õigeks säilitada vene kodukäijakujutlema tutvustavas tekstis vene mõistet domovoi (vrd nt Marriott 2009: 171-172), kuna vene kodukäijal võivad esineda lokaalsed erijooned (eriti omane on deemonliku ja vägivaldse käitumise domineerimine).

\section{Puuduv vaste}

Tõlketeoreetik Sider Florin (1993: 125) väidab seoses reaalidega ehk objektide ja fenomenidega, mida sihtkultuuri lugeja ei tunne ja mille kohta sihtkeeles vastet pole, et need ongi oma olemuselt üldjuhul tõlkimatud. Juhtudel, kui mingi märksõna eestikeelne tõlkeline või usundiline vaste puudub, on tihti ainus võimalus originaaltermin enam või vähem eestipärastatud kujul alles jätta (transkribeerida). Kui neid transkribeeritud originaaltermineid tõlkes kasutada, on üldjuhul vajalik selgitav lisakommentaar (nt joonealune märkus, selgitav laiendus tekstis, sõnaseletused teksti lõpus), muidu võib termini sisu jääda lugeja jaoks varjatuks. Näiteks aitab asjassepuutuvat lähtekultuuri mittetundvat inimest lisatud ühesõnaline eesti usundiga haakuv täiendus: "koduhaldjad brownie'd" (Marriott 2009: 172) või "koduhoidjahaldjas bean tighe" (Marriott 2009: 170). Sealjuures on kogemus näidanud, et geograafiliselt, keeleliselt ja kultuuriliselt kaugete ning seega eesti usundiga vähehaakuvate olendite nimetustega on lihtsam kui lähedasematesse kultuuridesse kuuluvatega, kuna kaugete kultuuride puhul on kergem otsustada võõrkeelse termini tõlkimatu ülevõtmise ja vastava olendidefinitsiooni lisamise kasuks. Eesti ja Lääne-Euroopa kultuuriruumi osas esineb osalist mentaalsuse kattumist, kuid piirkonniti ja valdkonniti tuleb ette ka tugevaid erinevusi, mida tõlkija peab teadma.

Ühe hea lahenduse leiab Tony Allani olendiraamatu eestindusest, kus ka sisuregistris on tõlkimatute olendinimetuste puhul toodud võimaluse korral sulgudes kompenseeriv lühidefinitsioon: far 
darring ("punane mees"), far gorta ("näljamees"), ceffyl dwr ("veehobune"), rakšasad ("näljased vaimud") (Allan 2009: 251-253).

\section{4. Üldnimetused ja isikunimed}

Üks keerulisemaid probleeme olendinimetuste ülevõtmisel just saksa keelest on küsimus, kas eelistada suur- või väiketähte, ehk teisisõnu, millal on tegemist üld- ja millal isikunimega. Saksa kirjapildis seda probleemi pole, kuna nimisõnad algavad niikuinii suure tähega. Eesti keele jaoks on ühtset reeglit raske leida.

Näiteks saksakeelse sõna Fangga vasteks jäi eesti keeles väikese tähega üldnimetus fangga, kuna saksa keeles kasutatakse sõna enamasti mitmuses (Fanggen, eesti vaste: fanggad) ja see märgib üldnimetusena teatud liiki hirmuäratavaid metsavaime.

Seevastu sõna Hehmann (eesti vaste: hehmann) kasutatakse enamasti ainsuses, ta on impersonaalne üksikolend, kes käib metsas ringi ja hüüab "heh" ja "hoi", kuid on mõeldud siiski üldnimetusena. Samuti kasutatakse sõna Rübezahl originaalis ainsuses, kuid tema puhul on tegemist konkreetse üksikolendiga, seetõttu sobib vasteks ka eesti keeles suurtähega kirjutatav isikunimi Rübezahl - seda hoolimata asjaolust, et nimetust oleks põhimõtteliselt võimalik sõnasõnaliselt tõlkida (Rübe - kaalikas, naeris; -zahl - arv, loendama) ja mitmetes süžeetüüpides on Rübezahli tegevuseks just naerite loendamine. Ent tõlkimine hägustaks seost originaalolendiga ja kaotaks seega ka osa olendi lokaalsest koloriidist.

Bercht esineb nii konkreetse personifikatsiooni nimena kui ka üldnimetusena (germaani kultuurist tuntud berchtijooksmine sarnaneb Eesti kombestiku martijooksmisega, sõna kasutatakse ka liiginimetusena: berchtid käisid öösel ringi), seega sõltub siin kasutus kontekstist.

Otsesed tõlkimatud laenud saksa keelest (eriti veel murdelisest saksa keelest), nagu enerbanske ja wicht on paratamatud uudissõnad, mis kirjutatud eesti keele reeglite kohaselt väiketähega tavasõna tasandil, kuna tegemist on üldnimetustega. Kindlate pärisnimede puhul säilib loogiliselt esisuurtäht (nt Ekke Nekkepen). 


\section{Sarnane kirjapilt, erinev sisu}

Huvitavaid avastusi pakkusid juhtumid, mille puhul mingi sõna saksa ja eesti keele kirjapilt on sarnane ja aimatav on isegi geneetiline seos, kuid käibel olevad sõnade tähendused on erinevad.

Eesti sõna $k r a t t$, mis märgib eesti keeles enda peremehele varanduse kokkukandjat, on keelelises mõttes tõlkelaen germaani sõnast Schratt, kuid tähendab eesti pärimuses sisult hoopis midagi muud, vastates pigem saksa usundis esinevale olendile nimega Drak. Saksa Schratt omakorda vastab eesti usundis olemuselt kõige enam mõistele painaja. Siia vahele mahub veel oletatav levikutee rootsi olendi skratt kaudu, kes sarnaneb funktsioonilt enam eesti usundi kratiga kui germaani Schratt.

Ka teine varavedajat märkiv nimetus (tuntud peamiselt Tartumaal ja kaugemal Lõuna-Eestis), nimelt puuk on pärit saksa keelest - see on tuletatud sõnast Puck, kuid originaaltermin Puck tähistab oma levikualal Põhja-Saksamaal hoopis teatud liiki majavaimu, mitte varakandjat. Seetõttu jäin deemonileksikonis sõna Puck eestindamisel segaduse vältimiseks originaalkirjapildi juurde.

Eriti värvikas näide mitmetähenduslikkusest on nimetus Ork, mis antiikmütoloogias märgib surmajumal Orcust, eeposes Beowulf kurja hiiglast, germaani rahvapärimuses merekoletist, luuletaja William Blake'i omamütoloogias esimeste inimeste mässumeelset last ja Tolkienil päkapikulaadseid mäekolle (vrd Colbert 2003: 101102). Vähe sellest, eesti usundis on ork (ja soome usundis horkka) hoopis mütoloogilise halltõve eufemism ning märgib mõningatel juhtudel ka katkuvaimu.

Mitmetel juhtudel on eesti kultuuris olemas nii nimevaste kui ka olendivaste, aga lokaalsetes joontes esinevad siiski erinevused. Neid on üsna raske mingi sõnavastega edasi anda, vajalik on pikem seletus või definitsioon.

\section{Paralleelnimetused ja alajaotused}

Peamurdmist valmistavad olukorrad, kui ühes keeles oli mingite teatud olendite jaoks olemas detailsem klassifikatsioon kui teises. 


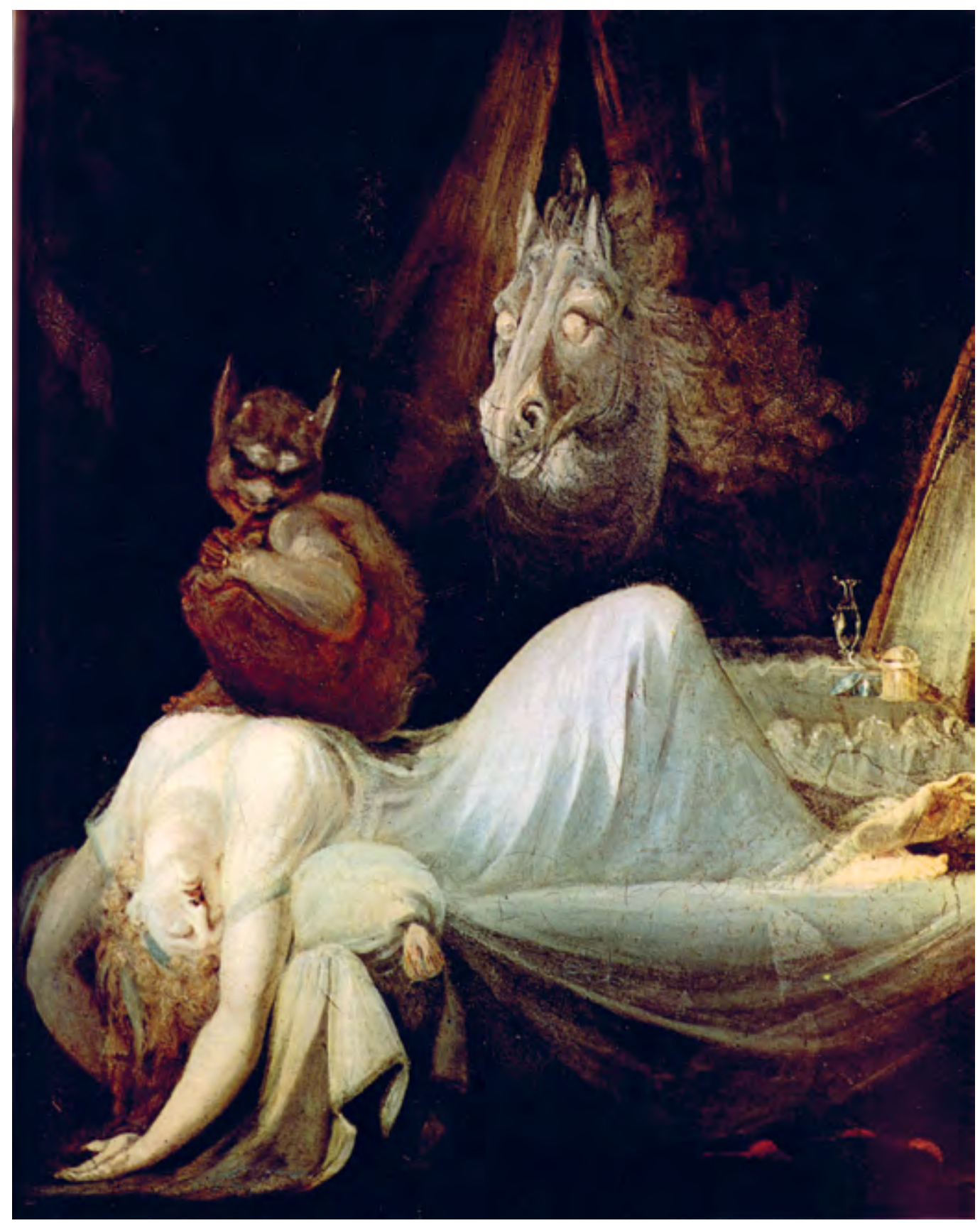

Luupainaja. Johann Heinrich Füssli. 1802. 
Näiteks eesti usundis on küll muistendid painajast populaarsed, kuid painajaolendi jaoks muid alternatiivseid nimetusi peale painaja ja luupainaja (ja nende derivaatide painakas, painjas jm) praktiliselt ei tuntagi. Seevastu on saksa keeles olemas Drud, Mahrt, Mahrrieder, Alp ja veel teisigi, mis käivad kõik üsna sarnaste painajaolendite kohta. Murdelises plaanis, tõsi küll, on märgata mõningaid eelistusi ühe või teise kasuks. Kuna eesti keeles piirkonniti ega murdeti painajaolendeid märgatavalt ei eristata, osutus mõttekaks säilitada lähedus saksa originaalterminitega, et erinevus siiski välja tuleks. Saksa Drud on üldjoontes nagu eesti usundi painaja, aga kuna saksa keeles on teda mõistest $A l p$ eristatud, pidasin selle vahe väljatoomise huvides vajalikuks jätta alles tsitaatsõna $d r u d$. Sama loogikat on järgitud peamiselt mõningates Ida-Saksa piirkondades kasutatava sõna Mahrt puhul, säilitades eesti vastes saksapärase sõnakuju mahrt, kuna siin on oluline ka geograafiline dimensioon - sama sõnatüvi kordub naabermaades (poola k mora, sorbi k murawa). Andes Mahrt'i vasteks lihtsalt painaja, läheks see lingvistiline seos kaduma. Alp on tõlgitud painajaks, kuna see on saksa keeles antud olenditegrupi kõige üldisem termin, painajaolendite katusmõiste.

Sarnased küsimused kerkisid üles seoses sõnaga Kobold - jätsin eesti vasteks koobold, kuigi see nimetus on eesti keeles vähekasutatav. Kooboldil on palju ühiseid jooni majavaimuga, kuid nende funktsioonid ja omadused pole siiski päris kattuvad. Samas viitab sõna Kobold keeleline taust pigem just sarnasustele kui erinevustele: Kob- keskülemsaksa keeles kobe, Kofen (säilinud nt uusülemsaksa sõnas Schweinekoben) tähendab (sea)sulgu, ruumi, maja. Teine silp -bold tähendab ülevaatajat, valitsejat. Kobold on seega 'majavalitseja'. Kibbermanni jt "Saksa-eesti sõnaraamat" pakub saksa sõnale Kobold vasteks 'ülemeelik majavaim, mäevaim', mis annab olendi olemust hästi edasi, kuid jääb siiski ümberütluseks. Tony Allani olendiraamatu eestinduses on kasutatud vastet kobold (Allan 2009: 12).

Eraldi kooboldilaadsete vaimumehikeste alaliigina esineb germaani usundis Wicht. Tundus mõttekas säilitada sama sõnakuju ka eesti keeles (wicht), et keeletundja jaoks jääks läbipaistvaks kesk- 
ülemsaksa keelest säilinud tähendusseos Wicht = 'olend, miski'. Sellega on ühenduses uusülemsaksa sõna nicht tekkimine vanaülemsaksa sõnast ni-wiht 'mitteasi, mitteolend, eimiski' (Petzoldt 2003: 211). Muutunud tähendusega on saksakeelne sõna Bösewicht, mida kasutatakse paha lapse kohta tähenduses 'paharet, marakratt'.

Huvitav näide on termin Elementargeister, mis germaani usundis märgib elementide (vesi-maa-tuli-õhk) personifikatsioone. Saksa kultuuris esineb seda mõistelist seost palju rohkemate olendite puhul kui eesti puhul, kus elementide järgi hierarhiate moodustamine on usundis üsna väheoluline. Eesti keeles on siiski olemas vaste elementaalid, kuid ilmselgelt pole see kunagi olnud rahvapärases kasutuses.

Järgnev on näide sellest, kuidas ühele saksa keeles üsna selgepiirilisele sõnale sobivad eesti keeles erinevad vasted, mis kõik edastavad mingeid lähtekeele sõna olulisi nüansse. Rahvakultuuri leksikon (Viires 1995) pakub sõna Zwerg eesti vasteks kääbus, kuigi kääbus on eesti usundis eraldi olendina üsna vähetuntud ja tal on pigem kurja ja pahatahtliku olendi maine. Sõna kääbus ise on vana ja seostub surnuteusuga (vrd kääbas), tähistades algselt hauas elajat (vrd Loorits 1949/57: 86). Juba Vestringi 18. sajandil koostatud sõnaraamatus esineb seos Härja Pölwe-Rahwas - Zwerge (Vestring 1998), mis oleks ilmselt üsna autentne vaste, kuid on sellise sõnakujuna praeguseks vananenud. Selle asemele on järkjärgult asunud sõna härjapõlvlane, mis on iseenesest Kreutzwaldi uudismoodustis. Härjapõlvlase olendikuju on germaani muinasjuttude toel (nt Lumivalgeke) ajapikku kujunenud järjest abivalmimaks ja heatahtlikumaks ning seega järjest kaugenenud kunagisest seosest surnuteusuga. Eesti pärimuses kannavad mõningaid saksa Zwergile omaseid jooni veel maa-alused, vähemal määral kasutatakse ka vastet päkapikk ja pöialpoiss. Otsustasin jääda vaste härjapõlvlane juurde, kuna see kannab endas kõige paremini mõiste keeleajaloolisi ja semantilisi tahke. 


\section{Sõna soo edasiandmine}

Saksa keeles annab sõnalõpu liide (nt -in) märku, et tegemist on naissoost olendiga, eesti keeles on samalaadne sõnamoodustus vähelevinud (nt kuninganna, Sööjatar), seetõttu tuleb eesti keeles sugu enamasti väljendada muul moel. Näiteks sõna Tödin vastena on võimalik kasutada sõna Surm ja lisada sulgudesse selgitus, et tegemist on just naissoost surmaga, kuna eesti usundis on olemas küll personifitseeritud surm (kes valdavalt ilmub mehe kujul), aga puudub eristus naissoost ja meessoost surmavaimude jaoks. Samuti oleks võimalik vaste naissurm, kuid ka selle puhul on paratamatult tegemist teatava kompromissiga; Tödin on rahvapärane nimetus, kuid naissurm on vaid sõna sisu edasiandev tehniline konstruktsioon. Samuti saab saksakeelsete olendinimetuste die Elbe või die Elbin eesti vasteks valida näiteks haldjas, haldjatar, naishaldjas või naissoost haldjas.

\section{Osa sõnast tõlgitav, osa tõlkimatu}

Seegi on kategooria, mille puhul sobivate vasteteni jõudmine ei tarvitse olla kerge. Niisuguste tõlkeolukordade lahenduseks võib olla see, et osa sõnast tõlgitakse ja osa transkribeeritakse, kuid asja teevad taas keeruliseks piirijuhtumid.

Kuidas tõlkida näiteks germaani olend nimetusega Heinzelmännchen: kas heinzel-mehike või transkribeerida kogu originaalsõna, jättes vasteks Heinzelmännchen? Lisandub veel see nüanss, et Heinz või Hinz esineb kohati sama olendi eesnimena: "Nagu muudegi majavaimude puhul tavaks (nt koobold), kannab ka tema inimesele omast eesnime Heinz või Hinz" (Petzoldt 2003: 83). Vähe sellest - ühe pärimuses teadaolevalt Lüneburgi lähedal elanud heinzelmännchen'i pärisnimeks olevat olnud Heintzelmann (samas). Teisalt kasutatakse sõna saksa keeles ka mitmusliku üldnimetusena die Heinzelmännchen, mõeldes selle all üldisemalt teatavaid koduhaldjalikke olendeid, keda näiteks perenaised endale meelsasti appi kutsuksid. Tundus otstarbekas jääda üldnimelise vaste heinzelmehike juurde. 
Sarnased küsimused kerkisid üles seoses sõnaga Kasermanndl - Eesti usundis pole ei vastavat olendit ega tabavat nimetusevastet. Pole raske järeldada, et sõna teine pool -manndl on kohaliku dialekti vaste sõnale Mann, kuid see ei ole eestindamisel abiks. Kasermärgib kohalikus dialektis karjasehütti, seega on äraseletatult tegemist karjasehüti-mehikesega, kes sügisel pärast karjuste lahkumist nende hüttides oma tempe teeb. Sõna-sõnalt tõlkides läheks aga kaduma nimetuse tore murdeline kõla, samuti olend ise, seetõttu pidasin vajalikuks jätta samasse teksti alles nii algse vormi kasermanndl kui kirjeldava vaste karjasehüti-mehike. Leian, et tõlkija peaks vähemalt püüdma selliste terminite tõlkimisel anda olulisi algkeele komponente edasi nii, et säiliks kombinatsiooni tähenduslikkus tervikterminina.

Saksa usundis esineb hulgaliselt mitmesuguseid naisolendeid, kelle nimetuse esimese poole moodustab sõna Frau: Frau Holle, Frau Hulda, Frau Hütt jt. Jätsin Frau Hütt vasteks ka eesti keeles Frau Hütt, mitte proua Hütt või emand Hütt, sest tegemist on kokkukuuluva sõnaühendiga, mis vahel esineb ka kokkukirjutatult Frauhütt. Samal ajal kohtab nimetust Holle saksa keeles nii ühendina Frau Holle kui ka ilma. Frau Holle vastena on varasemates tõlgetes esinenud ka emand Holle, seega tuleb siin tõlke valikul lähtuda haakuvusest konkreetse kontekstiga.

\section{Lõpetuseks}

Nagu nägime, sõltub olendinimetuste tõlkimisel sobiva sihtkeelevaste valik mitmetest asjaoludest - tõlke sihtrühmast, olendi- ja sõnavaste olemasolust sihtkultuuris, tähendusmuutustest jms. Tulevikuperspektiivina oleks nii tõlkijatele kui asjahuvilistele lugejatele abiks vastava veebipõhise, eri kultuuriareaale hõlmava sõnastikleksikoni loomine, mis sisaldaks lisaks definitsioonidele võimaluste piires ka illustreerivaid pärimustekste ja olendinimetuste võõrkeelseid vasteid ning oleks vastavalt vajadusele jooksvalt täiendatav. 


\section{Internetiallikad}

Eesti Ulmeühing: http://www.obs.ee/ taavi/esfa

Fantastikahuviliste portaal: http://www.dragon.ee

Olendite veebilehed: http://www.daemonen.de; http://www.geisterarchiv.de, http://www.enctype.de/Daemonen/frame.htm; http://www.eaudrey.com/myth Tolkieni-huviliste veebileht: http://www.keskmaa.ee

Tuulepesa foorum: http://tuulepesa.zzz.ee/

Ulmehuviliste veebileht: http://www.ulme.ee

\section{Kirjandus}

Agar, Michael 2006. Culture: Can you take it anywhere? - International Journal of Qualitative Methods, no 5: 2, pp. 1-16.

Allan, Tony 2009. Mü̈̈tilised olendid. Illustreeritud kogumik, mis tutvustab maailma kõige fantastilisemaid olendeid. Tallinn: Varrak.

Colbert, David 2003. Sõrmuste isanda võlumaailmad. Tallinn: Pegasus.

Eisen, Matthias Johann 1922. Näkiraamat. Tartu: Kool.

Florin, Sider 1993. Realia in translation. - Translation as Social Action. Russian and Bulgarian Perspective. Ed. Palma Zlateva. London: Routledge, pp. 122-128.

HDA I = Handwörterbuch des deutschen Aberglaubens. Band I. 1927. Hrsg. E. Hoffmann-Krayer, Hanns Bächthold-Stäubli. Berlin, Leipzig: de Gruyter.

Hiiemäe, Mall 2003. Maa-alused ja mailase rada. - Keel ja Kirjandus, 10, lk 760-769.

Kibbermann, Elisabeth, Kirotar, Salme, Koppel, Paula 1976. Saksa-eesti sõnaraamat. Tallinn: Valgus.

Loorits, Oskar 1949-1957. Grundzüge des estnischen Volksglaubens I-III. Skrifter utgivna av kungl. Gustav Adolfs Akademien för Folkslivsforskning 18:1. Lund. 
Manninen, Ilmari 1925. Etnograafiline sõnastik. Tartu: Loodus.

Marriott, Susannah 2009. Haldjad. Tallinn: Varrak.

Petzoldt, Leander 2003 [2010]. Väike deemonite ja vaimolendite leksikon. Tartu: Eesti Kirjandusmuuseumi folkloristika osakond [täiendatud uustrükk 2010].

Schleiermacher, Friedrich 1813.Ueber die verschiedenen Methoden des Uebersezens (24. Juni 1813). Internetis (vaadatud 31.01.2012):

http://www.muenchner-uebersetzerforum.de/Medien/Schleiermacher_Ausz. pdf.

Sturge, Kate [2012]. The Other on Display: Translation in the Ethnographic Museum. Aston University. Internetis (vaadatud 31.01.2012): http://www.soas. ac.uk/literatures/satranslations/sturge.pdf.

Torop, Peeter 2011. Tõlge ja kultuur. Heuremata. Humanitaarteaduslikke monograafiaid. Tallinn-Tartu: Tartu Ülikooli Kirjastus.

Torop, Peeter 2003. Tõlkesemiootika loeng Tartu Ülikoolis. Veebruar-aprill 2003. Konspekt.

Vestring, Salomo Heinrich 1998. Lexicon Esthonico Germanicum. Tartu: Eesti Kirjandusmuuseum. Internetis (vaadatud 31.01.2012): http://www.folklore. ee/ kriku/VESTRING.

Viires, Ants (koost.) 1995. Eesti rahvakultuuri leksikon. Tallinn: Eesti Entsüklopeediakirjastus.

Wiedemann, Johann Ferdinand 1876. Ausdem innerem und äusseren Leben der Ehsten. St. Petersburg: Buchdruckerei der Kaiserlichen Akademie der Wissenschaften. 


\section{Summary}

\section{Gnomes, imps and goblins. On the nuances of translating terms for supernatural beings}

Folk belief and mythological beings have not ceased to attract attention in the modern cultural communication. When we translate masterpieces of other cultures (e.g. folk epics), it is unavoidable to be informed about the original culture as well as its connections with the target culture. The same is true when we translate only one word (e.g. the name of a supernatural being or a cult object) - it is necessary to know its cultural background, even though the translation in the target language may also consist of only one word.

The paper gives an overview of some problems that occur in translating the names of supernatural beings. What to do if a word has no equivalent in the target culture or language, or when a word looks similar and is linguistically derived from the source language, but that has a different meaning in the target culture? The cases when one culture has a more elaborated system of certain supernatural beings than the other also create problems. In some instances, only a part of the name is translatable. Difficulties may arise when one and the same word can be used as a general term and as a personal name (especially characteristic to German language), or when there are differences in cultures based on monotheistic and polytheistic world views. Translating gendered names into languages where the gender is not marked by linguistic means also poses difficulties. Some possible ways of overcoming such translation problems are outlined in the article. It must be emphasised that solutions are not universal but context-based.

It is interesting to observe the role of certain translations in shaping the empirical experiences of individuals. In Estonia (as well as in many other civilised countries) numerous people perceive that they have contacts with the spiritual world. Yet the spectrum of supernatural beings met has widened in the course of cultural glo- 
balisation. As a result, new terms and ways of defining and describing the supernatural world have emerged.

Key words: translating, folk belief, supernatural beings, empirical experience, cultural context 


\section{Mõningaid võrdlusmomente Kesk-Assüüria ja Uus-Assuiüria raidkirjadest, kroonikatest ja annaalidest 1500-612 eKr ning nende tekstide tõlkimisega seotud probleemid}

\section{Vladimir Sazonov}

Teesid: Käesolev artikkel vaatleb Assüüria kuningate ametlikke tekste - raidkirju, annaale ja kroonikaid valikuliste ametlike tekstide näidete põhjal, mis pärinevad eri ajastutest, jälgides, kuidas arenes Assüürias "ajaloo" kirjutamine ehk kuidas arenes välja kroonikate, annaalide ja raidkirjade koostamine läbi II ja I eelkristliku aastatuhande. I eelkristliku aastatuhande alguseks leiab aset sellise žanri väljakujunemine nagu "annaalid”. Annalistika areneb eriti Uus-Assüüria impeeriumi ajastul. Samuti näidatakse artiklis ametliku propaganda arengut Assüürias, sest kõik ülalmainitud tekstiliigid olid propagandistliku sisuga - eesmärgiga kiita valitsevaid kuningaid ning ülistada nende tegusid, legitimeerida nende võimu ning tugevdada positsioone. Tähelepanu pööratakse ka mõningatele tähtsamatele küsimustele ja probleemidele, mis on seotud niisuguste tekstide tõlkimisega.

Märksõnad: Assüüria, kroonikad, raidkirjad, annaalid, ideoloogia, kuningas, propaganda, tõlkeprobleemid. 


\section{Sissejuhatus ja ajalooline taust ${ }^{7}$}

Käesolevas artiklis vaatleme vaid valikuliselt mõningaid näiteid Kesk-Assüüria (u 1500-1000 eKr) ja Uus-Assüüria (u 900-612 eKr) kuningate kroonikatest, raidkirjadest ja annaalidest. Suurem osa näiteid on pärit Uus-Assüüria ajastust ehk siis perioodist, mida dateeritakse alates Aššurnasirpal II (883-858) valitsemisest kuni Uus-Assüüria impeeriumi hävinguni, mis leidis aset 612. a eKr (Assüüria ajaloo kohta vt lähemalt Artzi 1978: 25-41; CancikKirschbaum 2003; Faist 2001; Harrak 1987; Heinhold-Krahmer 1988: 79-104; Holloway 2002; Lambert 1974: 103-109; Llop Raduá 2001; Mayer 1995; Oded 1979; Olmstead 1917: 169-185; Brinkman 1997: 1-16.). Samas on toodud näited ka Vana-Assüüria perioodist (2000-1500 eKr), et paremini demonstreerida kroonikate ja raidkirjade kirjutamise arengut ja mõista, kuidas tekkis ning arenes Assüürias "ajaloo kirjutamine".

Artikli sissejuhatavas osas anname põgusa ülevaate Assüüria ajaloost alates Aššuri linnriigi tekkest ning analüüsime ka varasemate perioodide kuninglikke tekste, eelkõige raidkirju, aga ka kroonikaid. Siinkohal tuleb märkida, et arvestama peab tohutu kirjaliku pärandiga, mis meieni on jõudnud uus-assüüria kroonikate ja annaalidena (vt nt Grayson 1975; Grayson 1976; ITN; Glassner 2004; Stein 2000; Grayson 2002; RIMA 3; Rasmussen 1897; Wiseman 1958; Parpola, Watanabe 1988; Tadmor 1994;RINAP 4). Teatud perioodide tekstide korpused võivad olla väga mahukad ning seetõttu on käesoleva artikli autor keskendunud vaid valikuliselt mõningatele näidetele, mis kõige paremini võiksid illustreerida neid akkadi keele assüüria dialektis kirja pandud annaali- ja kroonikalaadseid tekste, mis on täiesti omaette žanr akkadikeelses kirjanduses. Assüüria kroonikaid, annale ja raidkirju on uuritud

7 Käesolev artikkel valmis Eesti Teadusfondi grantide 8669 ja 8993 toetusel. Muistse Mesopotaamia varasemate perioodide jaoks kasutatakse pikka, keskmist ning lühikest kronoloogiat. Artikli autor eelistab kasutada keskmist kronoloogiat. 
ja analüüsitud ka varem (Borger 1961; Liverani 1992; Röllig 1967: 173-184; Yamada 2000).

Esmalt aga mõni sõna Assüüria riigi kujunemisest. Võimas Uus-Assüüria impeerium sai 9-7 saj eKr alguse väikesest PõhjaMesopotaamia linnriigikesest nimega Aššur, mis oli alguses sõltuv muistsetest Mesopotaamia suurriikidest ja ei mänginud mingit rolli kuni II eelkristliku aastatuhande teise pooleni. Kuid muistsed Mesopotaamia administratsiooni etableerumise traditsioonid ja võimustruktuurid olid assüürlastele tuttavad juba vähemalt Akkadi (2354-2154) ja Uus-Sumeri (2112-2004) ajastust, mil Aššur oli väike provintsilinn võimsa Akkadi impeeriumi ja hiljem Uus-Sumeri suurriigi koosseisus. Aššur ise, hilisem tulevase tugeva Assüüria impeeriumi poliitiline keskus ja tuumik, oli II eelkristliku aastatuhande alguses veel väike ja poliitiliselt üpris nõrk, kuid samas rikas linnriik. Selle majandusliku tugevuse baas oli loodud 20-19 saj eKr. Aššuri linna kaupmehed koloniseerisid edukalt Väike-Aasia idapoolseid alasid. Niisiis sai Aššuri linn rikkaks oma linna kaupmeeste tõttu, kuna nad rajasid üpris aktiivselt oma kaubanduslikke keskusi ja kolooniad Anatoolia aladele. Tuntuim selline muistne keskus oli karum Kaneš ${ }^{8}$ (Jankovskaja 1968; Veenhof 1972).

19. saj lõpus sattus Põhja-Mesopotaamia, sealhulgas Aššuri linnriik amoriidi päritolu kuninga Šamši-Adad I (1813-1781) ülemvõimu alla, kes lõi Põhja-Mesopotaamia ja Süüria aladele võimsa suurriigi. Kuid pärast Šamši-Adad I surma, mis leidis aset ca 1781. eKr, käis Šamši-Adadi suurriik alla.

Oma valitsemise ajal tugev ja militaristlike kalduvustega ŠamšiAdad I kontrollis tervet Põhja-Mesopotaamia piirkonda kuni Eufrati jõeni välja. Ta määras oma poegi ja sugulasi vallutatud aladele asehalduriteks ja valitsejateks. Näiteks üks tema poegadest Išme-Dagan sai niimoodi Ekallatumi linna valitsejaks ning ta

8 karum Kaneš - türgipäraselt Kültepe - Türgi aladel asuv muistne ruuniküngas Kaneš oli rajatud juba vähemalt III at eKr. II aastatuhande alguses eKr lõid Aššuri kaupmehed seal oma kaubandusliku koloonia, mis puhkes õitsele ja sai teiste kolooniate peamiseks keskuseks. Sellise kaubandusliku keskuse nimetus akkadi keeles oli karum. Vt. Mayer 1995: 145. 
võimu alla olid koondatud kõik suurriigi ida-alad, tema teise poja Jasmah-Adadi residents paiknes aga Süüria aladel asuvas Mari linnas ning talle kuulusid Eufrati jõge ümbritsevad maad. Oma pealinnaks valis Šamši-Adad Sehna linna, nimetades selle ümber Šubat-Enliliks (“Jumal Enlili residents”). Šamši-Adadi surmaga varises kokku ka tema loodud impeerium. ${ }^{9}$

18. saj keskel eKr sattus Aššur järgmise suurvallutaja - Babüloni kuningas Hammurapi (1792-1750) suurriigi koosseisu, kuid juba Hammurapi poja Samsuiluna (1749-1712) ajal kaotasid Vana-Babüloonia kuningriigi (1894-1595) kuningad kontrolli Põhja-Mesopotaamia üle, kuhu tungisid sisse mägirahvad - kassiidid. 15. saj eKr muutus Aššur sõltuvaks hurriitidest, kes lõid tugeva Mitanni suurriigi Süüria ja Põhja-Mesopotaamia aladel (Solovjova, Nemirovski 2007: 140).

Ligikaudu 1595. eKr langes Babüloonia suurriik, kui selle vallutasid hetiidid. Pärast seda hakkasid Babüloonias valitsema hetiitide liitlased kassiidid. Kassiidid olid tundmatut päritolu, mägedes elavad hõimud, kes ilmusid kusagilt Iraani aladelt. Sel ajal eksisteeris Süürias ja Põhja-Mesopotaamias terve rida linnriike ja üks neist paljudest linnriikidest oli Aššuri linnriik. Aššur oli tollal poliitiliselt sõltuv kas huriitidest või kassiitidest. Aššuri valitsejad tegid ilmselt katseid lõplikult iseseisvuda ja saavutada suuremat mõjuvõimu. 14. saj II poolel eKr olukord aga muutus. Aššuri linna valitseja Aššuruballit I (1365-1330) sai esimeseks Assüüria kuningaks, kes kandis ka ametlikult "kuninga" tiitlit. Ta oli üpris edukas nii sise- kui välispoliitikas. Olles auahne ja soovides teha Aššurist suurriiki, hakkas Aššuruballit I suhtlema Egiptuse suurkuninga ehk vaaraoga nagu võrdne võrdsega ning hakkas nimetama vaaraod vennaks, mis tähendas seda, et ta pretendeeris suurkuninga staatusele ja tahtis olla võrdväärne teiste suurkuningatega - Egiptuse, Babüloonia ja Hetiidi kuningatega. Nii saigi temast varsti peaaegu terve Põhja-Mesopotaamia valitseja. Nagu mainitud, nimetas

9 Cancik-Kirschbaum 2003: 37-38. 
Aššuruballit I ennast nüüd juba kuningaks (̌̌arru). Ametlikes raidkirjades ei riskinud ta seda veel teha, kuid kirjavahetuses küll. ${ }^{10}$

Tema järglased Aššuri troonil jätkasid ta ekspansioonipoliitikat - näiteks kuningas Adadnārārī I (1307-1275) oli edukas vallutaja, kes pidas vallutussõdu nii lõunas kui ka põhjas. Tema poeg Salmanassar I (1274-1245) sõdis Mitanni kuningriigiga (Hanigalbat ehk hurriitide kuningriik), aga tal oli sõjalisi kokkupõrkeid ka Anatoolias elavate hetiitidega, samuti uruatri hõimudega (tulevane Urartu) jne. ${ }^{11}$ Järgmine kuningas Tukultī-Ninurta I ${ }^{12}$ (1244-1208) paistis silma veelgi suurema vallutajana. Vägivaldne despoot Tukultī-Ninurta I tugevdas juba niigi võimsat Assüüriat, laiendades impeeriumi piire teiste riikide arvelt. Oma võimsuse tippajal suutis Tukulti-Ninurta I kontrollida peaaegu tervet Mesopotaamiat, "neelates alla" nii Põhja-Mesopotaamia kui ka Lõuna-Mesopotaamia alad. Babüloonias valitsenud kassiitide kuningas Kaštiliaš oli sõjas purustatud ja sattus vangi (Mayer 1995: 214-215). Kassiitide suurriigi pealinn Babülon oli vallutatud ja laastatud, assüürlased olid jumal Marduki kuju Babülonist minema viinud (Weidner 1939-1941: 119). Kuid Tukultī-Ninurta I lähedastele ja õukondlastele ei meeldinud tema karm valitsemisviis. Tekkis vandenõu, mille tulemusena kuningas kuulutati hullumeelseks, kõrvaldati troonilt, vangistati ning seejärel mõrvati 1208 . või 1207. a paiku eKr. ${ }^{13}$

Kõik Tukultī-Ninurta I tehtud vallutused läksid kaotsi. Tegelikult ei läinud tal juba oma võimu lõpuaastatel enam nii hästi ja ta kaotas kontrolli Babüloonia üle, pärast ta surma käis Assüüria kiiresti alla (Sazonov 2010a: 148-150). II eelkristliku aastatuhande lõpus elas Assüüria üle veel ühe väga lühikese tõusu, mis oli seo-

10 Vt. näiteks Artzi 1978: 27, kiri nr 15, rida 3; vt Aššuruballit I kohta Sazonov 2010a: 69-76.

11 Salmanassar I vallutustest ja Assüüria administratsiooni loomisest Hanigalbatis (hurritide riik) vt Harrak 1987: 132-205; Vt ka Mayer 1995: 203205; Vt ka RIMA I, A.0.77.1, lk 183-185.

12 Tukultī-Ninurta I kohta vt Weidner 1939-1941:109-124; Klengel 1961: 67-77; Lambert 1976: 85-94; Lambert 2004, 197202.

13 Tukultī-Ninūrta I surma kohta vt Sazonov 2010a: 148-149; Sazonov 2011: 235-276; Yamada 1998: 26-27. 
tud Tiglatpileser I (1115-1077) nimega. ${ }^{14}$ Kuid tõeline Assüüria tõus algas alles I eelkristlikul aastatuhandel eKr, mil temast kasvas välja võimas kontinentaalne Uus-Assüüria impeerium. UusAssüüria impeerium sai I eelkristliku aastatuhande esimesel poolel Lähis-Idas vaieldamatult kõige võimsamaks poliitiliseks, sõjaliseks ja majanduslikuks jõuks. Assüürlased domineerisid Lähis-Idas ca 200 aastat, alates Kesk-Türgi aladest ja Kaukaasiast kuni Egiptuseni välja (Egiptuse vallutasid nad siiski vaid lühikeseks ajaks), Palestiinast Lääne-Iraanini ning Araabia poolsaareni. Uus-Assüüria impeerium oli esimene kontinentaalne impeerium maailma ajaloos, tohutult suur, multietniline, kus elas kümneid miljoneid inimesi, hästi toimiva administratsiooniga, võimsa ja mobiilse armeega ning karmi valitsemisviisiga, kus kasutati ohtralt repressiivseid meetmeid, s.h. küüditamist. ${ }^{15}$ Impeerium oli loodud vägisi - mõõga ning hirmuga. Selleks, et ära hoida selle lagunemist ja suruda maha mässulist meelt ning separatismi, kasutati luuramist, koputamist, küüditamist ja terrorit. Samal ajal muidugi arenes ja õitses Uus-Assüüria riigis kaubandus ja majandus, soositi ning toetati ustavaid vasallriike ja lojaalseid provintse ning nende elanikkonda ja ülikuid.

Uus-Assüüria kuningriik muutus 9. saj jooksul Aššurnasirpal II (883-859) ja tema poja Salmanassar III (859-824) ajal võimsaks impeeriumiks ning Assüüriast sai 9. saj teiseks pooleks praktiliselt ainus domineeriv ja tähtsam suurjõud, mis mõjutas järgmised ligi 250 aastat kogu Lähis-Ida välis- ning sisepoliitilist elu. Juba 9. saj eKr arenes assüürlaste võimas agressiivne vallutuspoliitika neljas suunas: lõunasse, põhja, itta ning läände. Vallutused ja sõjad jätkusid ka 8. ja 7. saj Uus-Assüüria impeeriumi lõplik häving leidis aset ajavahemikul 630-612 a eKr (vt. näiteks Sazonov 2006: 83; Mayer 1995: 412-418).

Niisiis tegid suur edu välispoliitilisel areenil, sõjalised võidud, keskvõimu tugevnemine jne Aššuri linnriigist 14.-13. sajandi jooksul võimsa Assüüria impeeriumi, mille jõudu ja prestiiži tunnusta-

14 Tiglatpileser I kohta Olmstead 1917: 169185.

15 Küüditamise kohta Assüürias vt Oded 1979; Sazonov 2010b: 153-174. 
sid ka teised Idamaade suurriigid nagu Egiptus, Hetiidi impeerium (1460-1180 eKr) ja Babüloonia kuningriik. Oma uudse sõjapoliitikaga, militaarsete sammudega ja võimu konsolideerimisega viis Assüüria administratsiooni tippladvik oma riigis sisse ka uuendused kuningavõimu ideoloogias, valitsemisviisis, valitsemiskontseptsioonides, administratiivses süsteemis jne. Kuid assüürlased polnud mitte ainult homo novus'e tüüpi leiutajad, vaid ka transformaatorid ja laenajad, kes laenasid teistelt rahvastelt ja riikidelt, kuid kohandasid ning transformeerisid ülevõetud nähtusi ja ideid, tehes neid endale mugavamateks ja vastuvõetavamateks (Sazonov 2010a: 237).

Assüüria võimsuse kasvuga muutus ka ametlik riiklik propaganda, arenes retoorika ja tekkis ajalookirjutus. Hetiitidelt õppisid assüürlased kirjutama annaale (vt del Monte 1993). Kroonikate koostamine oli neil juba ammu tuntud ja selle olid nad õppinud Mesopotaamiast - Babülooniast jne. Järgnevalt vaatleme Assüüria kuningate raidkirjade, annaalide ja kroonikate arengut. Kuid enne seda tuleks rääkida ka raskustest ja probleemidest, mis on seotud selliste tekstide tõlkimisega algallikatest.

\section{Mõningad olulisemad võtmeprobleemid seoses Assüüria kroonikate ja raidkirjade tõlkimisega}

Assüürlased nagu ka teised muistsed Mesopotaamia rahvad kasutasid kiilkirja, mille kunagi leiutasid sumerlased. Asssüürlased kasutasid akkadi keele assüüria dialekti, mis omakorda alates II aastatuhande algusest kuni I aastatuhande alguseni tegi läbi mitu arengufaasi - vana-akkadi keele üleminek vana-assüüria keeleks ca 2000 a eKr, seejärel kesk-assüüria dialekti teke ja areng 15.-11. saj eKr ja uus-assüüria dialekti areng 9.-7. saj, mil akkadi keel oli juba tugevasti mõjutatud aramea keele poolt - teisisõnu arameiseeritud. Muidugi olid igas dialektis omakorda aladialektid ja akkadi keel, mida kasutasid assüürlased Dur-Katlimmus 13. saj eKr, erines 
kohati drastiliselt sellest, mida kasutasid assüürlased näiteks 9. saj Ninives.

Nimetagem mõned olulisemad töö etapid, milles esile tulevate probleemidega puutub kokku selliste tekstide tõlkija:

1) kiilkirjatahvlite dešifreerimine;

2) kiilkirjamärkide translitereerimine;

3) tõlkimine;

4) mõistete tõlgendamine.

Dešifreerimine võib olla mõnikord väga tülikas ja keeruline ülesanne, eriti siis, kui tekst on halvasti säilinud või mingid laused või sõnad on kaheti mõistetavad või mõnel kiilkirjamärgil on mitu tähendust ja on raske otsustada, milline on selles kontekstis õige, sest valides vale märgi või sõna, võib muutuda kogu teksti sisu.

Lisaks raskendab tõlkimist ka asjaolu, et mõned tekstid on säilinud osaliselt, näiteks mingid kiilkirjamärgid on kadunud või isegi terved read on hävinenud. Tihti tuleb rekonstrueerida konteksti järgi, mõnikord pole see aga võimalik. Siinkohal toon ühe näite kesk-assüüria ajastust, mis seda probleemi hästi illustreerib.

On olemas kiri (pärit Ugaritist) $R \check{S} 34.165$ - see on Assüüria kuninga kiri, mis on saadetud Ugariti valitsejale, kes oli 14-13 saj eKr Hetiidi suurkuningate vasall. Kirjas on juttu sellest, kuidas "vennalikud" suhted Assüüria ja hetiitide vahel katkesid, kuna nende vahel puhkes sõda Nihria ${ }^{16}$ linna pärast (Nemirovski 2008: 5-7). Nihria all toimunud lahingus sai Hetiidi kuningas Tuthalija IV assüürlaste käest lüüa. Vähemalt nii väidab Assüüria kuningas, kes isiklikult selle kirja koostas. Kuid kes see Assüüria kuningas võis olla? Kas Salmanassar I või Tukultī-Ninurta I? Saatja nimest on säilinud vaid märgid ... SAG LUGAL KUR... - “... SAG, Assüüriamaa kuningas..." (Nemirovski 2008: 6).

Üks tõlgendamisvõimalus on, et SAG ette käis märk UR, mis kokku annab UR.SAĞ ehk 'kangelane' (akkadi keeles hääldati seda qarrādu $(m))$.

Teine variant on see, et märk SAG võib kuuluda Salmanassari nimesse (originaalis kirjutati ta nimi šùl-ma-nu-SAGja sedaloe-

16 Võib olla tänapäeva Diyarbakir'i kandis. 
takse akkadi keeles Šulmanu-ašared) - see tundub loogilisema ja tõenäolisema teooriana (Nemirovski 2008: 6). Seda toetab ka asjaolu, et uurides kuningate Salmanassar I ja Tukultī-Ninurta I titulatuuri nende raidkirjades, ei leidnud ma, et epiteeti UR.SAG ehk qarrādu(m) 'kangelane'oleks kasutatud enne tiitlit šar māt Ǎšsur 'Assüüria kuningas'. Salmanassar I puhul seal, kus ta kasutas tiitlit "Assüüria kuningas”, algas ta titulatuur tavaliselt järgmiselt: Šulmanu-ašared šar kiššati šarru dannu šar māt Aššur - Salmanassar, universumi kuningas, võimas kuningas, Assü̈̈ria kuningas (RIMA 1, Shalmaneser I A.0.77.6, lk 186, read 1-3).Ka Tukulti--Ninurta I titulatuuris ei näe me midagi selletaolist (Sazonov 2010a:96-148). Kirjades kasutati epiteeti UR.SAG muidugirohkem, aga ikkagi mitte enne kuninga ametlikku tiitlit "X maa kuningas". Näitena toon Hetiidi suurkuninga Šuppiluliuma I (1380-1340) tiitli alguse ühest tekstist:

1. um-ma d ${ }^{\mathrm{U}} \mathrm{TU}$-ši ${ }^{\mathrm{m}} \mathrm{S}$ u-up-pi-lu-li-ma ${ }^{17}$

2. LUGAL GAL LUGAL KUR Ha-at-ti UR.SAG (Aboud 1994: 48, read 1-2)

1. Järgmisel viisil kõneleb Minu Päike, Šuppiluliuma,

2. suurkuningas, Hatti18maa kuningas, kangelane.

Seega peab selliste tekstide tõlkija olema kursis tegelikult tervete tekstikorpustega, et vajadusel lünki täita.

Peatume põgusalt mõistete tõlgendamisega seotud raskustel. Paljusid termineid, mis on seotud näiteks Assüüria sõjandusega, küüditamisega või taimede, maagia ja meditsiiniga, on tänapäeva keeles raske edasi anda. Peamiseks põhjuseks on see, et esiteks pole meil veel terviklikku pilti nendest muistsetest kultuuridest ja teiseks pole leitud veel kõiki allikaid, mis võiksid paljude mõistete tõlgendamisel abiks olla. Terminoloogia valdkonnast toon vaid ühe näite. Näiteks kasutati küüditatute kohta Assüürias omi termineid ja neid oli koguni mitu. Siin mainiksin ära järgmised - sumero-

17 Siin on kuninga nimi kirjutatud valesti, peaks olema kiilkirjas $\check{S} u$-up-pi-luli-u-ma.

18 Ehk Hetiidi impeerium, mis eksisteeris 15 saj-12 saj alguseni eKr. 
gramm ${ }^{19}$ lúERIM.MEŠ, akkadi keeles şābū; sumerogramm ÙKU. MEŠ, akkadi keeles nišü; sumerogramm ZI.MEŠ, akkadi keeles napšăti (Oded 1979: 22).Kõik need mõisted esinevad Assüüria kuningate annaalides ja muudest tekstides. Näiteks selline väljend nagu niše şeher rabi zikar u sinniš esineb tihti Uus-Assüüria kuningate raidkirjades (Sargon II, Sennaherib). Seda võib tõlkida kui 'inimesi, suuri ja väikeseid, meessoost ja naissoost...' (Oded 1979: 23). Nišū võis tähendada teatud kontekstis rahvast, ka niisama inimesi ja ka mehi, sõjamehi. Seega peab kindlasti oskama mõisted õigesti tõlkida ja just lähtuvalt kontekstist.

Veel üks küsimus, millele tuleks pöörata erilist tähelepanu, on see, et eri liiki tekstid nõuavad ka erisuguseid tõlkemeetodeid. Oma tõlkekogemuse põhjal võin öelda, et näiteks propagandistliku sisuga tekstid (nagu raidkirjad, kroonikad jne) sarnanevad enam ilukirjanduslike tekstidega, mille tõlkimisel tuleb edasi anda eelkõige emotsiooni ja peamist mõtet, samal ajal kui näiteks seaduste tõlkimisel tuleb eelkõige pöörata tähelepanu selgele sõnastusele ja täpsusele.

Tõlkimisel tänapäevastesse keeltesse on kindlasti veel üks tähtis probleem - lauseehitus. Kuna akkadi keele puhul on tegemist semiidi keelkonna ida-semiidi harusse kuuluva keelega, erineb selle grammatika väga näiteks eesti keele omast. Kas tõlkimisel tuleks jätta sõnajärg samasuguseks nagu on originaalis või peaks seda kohandama sihtkeele grammatikale? Tuleb vältida sõna-sõnalist otsetõlget, mis eesti keeles võib kõlada väga konarlikult ja kohati isegi arusaamatuks jääda. Seetõttu on ilukirjanduslike tekstide tõlkimise puhul peamiseks reegliks see, et tuleb kasutada nii originaalilähedast lausestruktuuri kui võimalik, aga seejuures peab sihttekst olema lugejate jaoks arusaadav ning mõelda tuleb ka sihtkeele stiili peale.

Tõlkimise seisukohast on oluline ka see, millisest perioodist konkreetne tekst pärineb. Seetôttu vaatleme järgnevalt Assüüria

19 Sumerogramm - sõna või väljend sumeri keeles, mida kasutati akkadi keeles kui laensõna või väljendit ja seda hääldati akkadi keele päraselt. Näide: sumerogramm LUGAL 'kuningas' häldati akkadi keeles kui šarru(m) ja see tähendas samuti 'kuningat'. Vt näiteks Kaplan 2006: 18. 
raidkirjade ja kroonikate arenguetappe kronoloogiliselt alates sellest ajast, mil meil on olemas esimesed valitsejate raidkirjad Aššurist.

\section{III eelkristliku aastatuhande lõpp ja II eelkristliku aastatuhande algus}

Kroonikaid ja annaale kui selliseid siis veel pole. On aga olemas esimesed Aššuri kuningate raidkirjad, mis on äärmiselt lakoonilised, struktuuri ning ülesehituse poolest lausa primitiivsed ja meenutavad vana-akkadi ning uus-sumeri raidkirju, kuid on enamasti siiski lühemad ja valitsejatel on tunduvalt tagasihoidlikum titulatuur (vt näiteks RIMA 1, A.0.35.1, lk 46; RIMA 1, A.0.60.2, lk 85).

Toon paar näidet. Esimesed teadaolevad akkadikeelsed raidkirjad Aššuri valitsejatelt pärinevad Akkadi ajastust (2334-2154), mil Aššur oli vasall-linnakesena võimsa Akkadi impeeriumi koosseisus. Esimene Aššuri valitseja või asehaldur, kellest on säilinud tekste, on Ititi. Oma raidkirja lasi ta koostada kivist tahvlile, mille arheoloogid leidsid Aššuri linna jumala Ištari pühamus. Raidkiri on äärmiselt lühike ja kõlab nii:

1-8.) i-ti-ti PA DUMU i-nin-la-ba in ša10-la-ti ga-surx(SAG).KI a-nadINANNA A.MU.RU. (RIMA 1, Ititi, A.0.1001, lk. 7, read 1-8.)

1-8.) Ititi, valitseja, Ininlaba poeg, selle (eseme) Gasuri tribuudist jumalanna Istarile pühendas

Siit algabki Aššuri raidkirjade areng, mis I eelkristliku aastatuhande esimesel poolel viis oma kompositsiooni ja stiili poolest väga keeruliste ning mahukate uus-assüüria annaalide ja kroonikate tekkimiseni. Ka Uus-Sumeri ajal 22-21 saj eKr jätkus selline tendents. Aššur oli Uus-Sumeri kuningate alluvuses kuni 2004. a eKr, mil Uus-Sumeri kuningriik hävis. 


\section{II eelkristliku aastatuhande esimene pool}

Järgmine huvitav võtmepunkt on II eelkristliku aastatuhande algus, mil Aššur sai esimest korda iseseisvaks linnriigiks. Tekkis oma kuningavõim, omad institutsioonid - enamasti muidugi mõjutatud Sumeri või Akkadi poolt. Raidkirjad on endiselt lühikesed, primitiivsed. Neid ei saa võrrelda pikkade ja põhjalikke raidkirjadega, mida koostasid Babüloonia suurkuningad, nagu näiteks Hammurapi. Aga Aššuri raidkirjades hakatakse toonitama, et valitseja on jumala asehaldur maa peal. Näiteks on nii tõlgendatud $2000 \mathrm{eKr}$ valitsenud Aššuri valitseja Şilulu raidkirja:

1-6.) $a$-šùr.KI LUGAL si-li-lu ÉNSI $a$-šùr.KI DUMU da-ki-ki NIMGIR URU a-šùr.KI.( RIMA 1, Şilulu A.0.27.1, lk 12-13, read 1-6)

Kuidas seda võiks tõlkida? Tasub kohe ära märkida, et Aššur oli assüürlaste tähtsam linn, nende riigi domeen, keskus, ja Aššur oli ka nende peajumal. Seega nii pealinn kui ka jumal kandsid ühte nime. $a$-šùr.KI LUGAL - see on huvitav koht. Akkadi keeles loeti seda kui Ǎ̌šrur šarru ehk 'jumal Aššur on kuningas', aga pärast sõna $A \check{s ̌ s} u r$ on determinatiiv ehk postnominatiiv $k i$, mis sumeri keeles tähendas mingit geograafilist piirkonda, seega Aššur.ki on hoopis linn Aššur ja sel juhul LUGAL ehk šarru on omadussõna. Raidkirja tuleks tõlkida siis järgnevalt:

1-6.) Aššuri linn on kuninglik, Silulu on Ǎšsuri linna asehaldur, Dakiki, Ařšuri linna heeroldi poeg.

Ühes huvitavas raidkirjas, mille koostas Ašsuri linna valitseja Erišum I (20. saj eKr), leiame sellise passaaži: 35.)... $a$-šù $r$ LUGAL 36.) i-ri-šu-um PA [a-šù $] r . .$. (RIMA 1, Erišum I, A.0.33.1, lk 21, read 35-36). Tõlkes on see 'Aššur on kuningas, Erišum on (tema) asehaldur'. See sarnaneb Silulu tekstiga, kuid siin on Aššur ilma determinatiivita "KI" ja tähendab seetõttu juba jumalat. See on huvitav, kuna sama väljend on 20. saj eKr kindlasti sarnane hilisema kesk-assüüria kroonimisrituaali tekstiga, mis koostati ca 13-12 saj eKr ja kus preestrid protsessiooni käigus laususid: "Aššur on 
kuningas! Aššur on kuningas!”20 Aga jätame nüüd vana-assüüria ajastu tekstid ja vaatame, mis toimus kesk-assüüria ajastul.

\section{Kesk-Assüüria raidkirjad}

Kesk-Assüüria ajastu I perioodil drastilisi muudatusi ei toimunud, seega periood 1500-1363 eKr meid siinkohal väga ei huvita. Muudatused tulid siis, kui Aššuri linnriik hakkas muutuma kuningriigiks ja sai 14. saj II poolel suureks territoriaalriigiks. See on seotud mitmete Aššuri valitsejatega, aga eelkõige Kesk-Assüüria kuninga Aššuruballit I-ga (1365-1330), keda võib vaadelda kui homo novust, sest just tema ajal leidsid Assüüria valitsemis- ja vallutamispoliitikas ning ka võimuideoloogias aset olulised muutused. Assüüria sai suurriigiks ja Aššuri valitseja saavutas 'kuninga' (̌̌arru) staatuse ning temast sai rahvusvaheliselt tunnustatud ning aktsepteeritud suurkuningas (šarru rabû). Assüüria kuningas oli nüüd igati võrdväärne teiste Lähis-Ida suurkuningatega. See tendents jätkus ning kasvas veelgi tema järeltulijate ajal. Iga uus valitseja Assüürias võttis ametlikes kuninglikes raidkirjades kasutusele uusi tiitleid ja epiteete. Tukultī-Ninūrta I valitsemisajaks kujunenud KeskAssüüria valitseja titulatuur oli väga auahne ning mitmekesine ja Kesk-Assüüria suurriik oli saavutanud oma territoriaalse maksimumi (Sazonov 2010a: 96-148; Sazonov 2011: 233-276).

Kesk-Assüüria kuningad ei kasutanud mitte ainult neid tiitleid ja epiteete, mida nad olid pärinud Aššuri valitsejatelt või võtnud üle naaberriikide valitsejatelt, vaid leiutasid ka ise mõned tiitlid ja epiteedid (selles osas paistsid eriti silma Salmanassar I ja TukultīNinurta I). Suurte vallutajate ja Kesk-Assüüria impeeriumi rajajate Adad-narari I, Salmanassar I ja Tukultī-Ninurta I raidkirjad muutusid nüüd eriti pikaks ja põhjalikuks (vt näiteks RIMA 1 A.0.78.5). Neil on pikk sissejuhatav osa nagu uus-assüüria kroonikatelgi, kus on tihti ära toodud kuninga täielik titulatuur, mis on muutunud

20 Vt lähemalt Müller 1937: 8-9, tulp I, rida 29: “Aššur šar Aššur šar2” - “Aššur ist König, Aššur ist König!”. 
üsna pikaks, kohmakaks ja auahneks; mainitud on ka genealoogiat ja kõiki tähtsamaid jumalaid, kes soosivad, toetavad või legitimeerivad valitseja suurkuninglust ja võimu. Propagandaaparaat arenes tohutult ja raidkirjades on juba põhjalikult loetletud kõik tähtsamad kuninga tiitlid, ka tema saavutused ning tekivad esimesed sõjakäikude kirjeldused. Ühest Tukultī-Ninurta I raidkirjast võib välja lugeda

Minu valitsemise alguses [ja] minu troonil olemise alguses deporteerisin ma 28800 hetiidi sõjameest sealpoolse Eufrati jõe kaldalt [Süüriast] ning tõin nad oma kuningriiki. Ma vallutasin Paphu ja Uqumanu maad kuni Šarnida ja Mehru maadeni. Igal aastal saan ma regulaarselt andamit nendest maadest ja nende mägede vilju [---]. Ma lömastasin oma jalge [ees] olevad kuningad, nende juhid, ja rakendasin nende suhtes orjust. Oma ületamatult tugeva võimsusega ületasin ma korduvalt [sageli] võimsaid mägesid [ja] ääretult raskeid vahemaid, radasid, mida ükski teine kuningas ei teagi (RIMA 1, A.0.78.23, read 27-42).

Suurte jumalate, minu isandate, jumalate Aššuri, Enlili ja Šamaši toetusel ning jumalanna Ištari abiga, taeva ja allilma emandaga, kes marsib minu armee ees, lähenesin mina Kaštiliašile, Karduniaši [Babüloonia] kuningale, et pidada lahingut [temaga]. Ma võitsin tema armee ja tapsin ta sõjamehi. Keset lahingut ma vangistasin Kaštiliaši, kassiitide kuninga [---] (RIMA 1, A.0.78.23, read 56-65).

Ajalookirjutus areneb edasi - võib leida juba üsna detailseid lahingute või sõjakäikude kirjeldusi, mis on uus-assüüria annaalidele väga omased.

Ka kuninglikus titulatuuris leiab aset murrang. Kui veel 15. saj või 14. saj alguses nimetas Aššuri valitseja ennast vaid Aššuri asehalduriks, siis 13. saj alguseks oli kõik muutunud ja kuningas Adad-nārārī I, kes tähistas end oma raidkirjades ametlikult kui šar $k i \check{s ̌ s} a t i$ - 'universumi kuningas', võttis kasutusele hulgaliselt uusi tiitleid ja epiteete, kusjuures mõned neist leiutas ta ise (Sazonov 2010a: 80-90). 
Alljärgnevalt vaid mõned näited:

1) murappiš mişri u kudurri - 'Maade ja piiride laiendaja' (Mayer 1995: 180; RIMA 1, A.0.76.1, lk. 131, rida 15: mu-ra-piš mì-iş-ri ù $k u-d u-r i)$;

2) Nēr (nāer) dapnūti ummān Kaššì Qutī Lulumī u Šubarī 'võimsate Kassiidi, Qutu, Lullumu ja Šubaru armeede võitja' (RIMA 1 A.0.76.1, lk.131, read 3-4).

Adad-nārārī I poeg Salmanassar I lisas uusi enda leiutatud tiitleid, nagu näiteks:

1) šar kiššat nišē - 'Kõikide inimeste kuningas' (RIMA 1 A.0.77.18 $1 \mathrm{k} 207$, rida 3)

2) sabit mişrat nakirī eliš u šapliš - 'Vaenulike alade vallutaja üleval ja all' (RIMA 1 A.0.77.1, lk 183, rida 18-19)

Kõnealune protsess kulmineerus Tukultī-Ninūrta I ajal, mil Kesk-Assüüria impeerium saavutas oma võimsuse tipu (Sazonov 2011: 233-276).

Niisiis iseloomustab kuninglikke raidkirju Adadnārārī I, Salmanassar I ja Tukultī-Ninurta I ajast kuningate ülistamine ja mõnikord vaenlaste halvustamine. Kuningat esitletakse vahel kui jumalikku kangelast, võitmatut, jumalate lemmikut, õiglast valitsejat.

Näitena valime vaid paar väikest fragmenti umbkaudu 60 -st Tukultī-Ninurta säilinud raidkirjast. Need ülistavad kõik viimseni Assüüria kuningat ning kirjeldavad ta vallutusi ja muid "kangelaslikke tegusid". Oma raidkirjades nimetas Tukultī-Ninurtaennast tavaliselt nii:

Tukutī-Ninūrta, universumi kuningas, võimas kuningas, Assüüria kuningas, nelja ilmakaare kuningas, kõikide inimeste päikesejumal, Salmanassari poeg ... (ITN 18, 1-3, lk. 31)

Või siis nii:

Tukulti-Ninurta, universumi kuningas, võimas kuningas, Assüüriamaa kuningas, Sumerimaa ja akkadlaste maa kuningas, nelja ilmakaare kuningas, Aššuri ja Šamaši lemmik olen ma - ülistatud võimukandja, kuningas jumal Enlili soosingul, 
kes õnnelikult oma valitsuskepiga maad rahulikult karjatab, kõrgem lunastus-preester, Anu poolt kutsutud... (ITN 16, 1-9, 26).

See pole veel kaugeltki lõplik nimekiri, kuna ainuüksi tema epiteetide nimekiri on selles raidkirjas 24 rida pikk, alles siis tuleb juttu tema vallutustest ja vägitegudest, millega võrreldes jäävad mitmedki Rooma ja Bütsantsi keisrid, Ottomani impeeriumi sultanid ja 16-18 saj Iraani valitsenud Safaviidide šahhid lihtsalt kahvatuteks isikuteks.

\section{Tukultī-Ninurta eepos ja kroonikad}

Üks huvitav kirjanduslik tekst, mis küll pole kroonika, aga on mainimisväärne, kuna käsitleb Assüüria kuninga Tukultī-Ninurta I sõdu ja tegusid, on akkadikeelne Tukultī-Ninurta eepos. ${ }^{21}$ See on huvitav propagandistlik teos, mille eesmärk oli ülistada Assüüria kuninga Tukultī-Ninurta I vägitegusid ning vallutusi. TukultīNinurta I on selles eeposes muuhulgas kujutatud Babüloonia peajumala Enlili pojana ja kangelasliku sõjaka vägilasjumala Ninurta vennana ning ka ise jumalikustatud kangelasena. ${ }^{22}$

Erilist huvi pakub rida 20', kus Tukultī-Ninurta I on mainitud Enlili pojana - úu-šar-bi-šu-ma ${ }^{d} E / I l l i l(\mathrm{BE}) k i$-ma a-bi a-li-de/i $a r-k i$ $m a \bar{r}(i)$ (DUMU) bu-uk-re/i-šu - 'Enlil kasvatas ta üles kui tõeline isa, pärast ta esmasündinud poega' (Machinist 1978: 68-69, rida 20').

See eepos oli loodud teatud eesmärkidega - asssüürlaste Babüloonia-vastase vallutuspoliitika õigustamiseks ning Assüüria valitseja isiku ülistamiseks. Benjamin R. Foster kirjutab: “TukultīNinurtat kujutatakes kui õiglast ja austusväärset kuningat, keda sundis Babülooniasse tungima ainult tema Babüloonia partneri Kaštiliaši reetlikkus, kes murdis kahe rahva vahel pikka aega

21 Vt Tukultī-Ninurta eepost B. Machinisti transliteratsioonis ja tõlkes Machinist 1978.

22 Foster 2005: 301-302, read 15'-20' 
kestnud lepingu. Tukultī-Ninurta hüüab appi tõotuste jumalat Šamaši, et see tunnistaks babüloonlaste reetlikkust, ning kutsub oma väed kokku. Hirmunud Babüloonia kuningas kahetseb oma väärtegusid ning üritab mitmesuguste riugaste abil otsest konflikti vältida. Olles viimaks sunnitud võitlusse astuma, põgeneb ta surmahirmus triumfeeriva Assüüria armee eest, mis marsib Babüloni ja rüüstab selle" (Foster 2007, 19-20). ${ }^{23}$ Kindlasti on mainimisväärt ka akkadikeelsed kroonikad, mis käsitlevad kesk-assüüria aega, näiteks "Sünkronistiline kroonika” (Glassner 2004: 176-183) või "Adrik-Dēn-Ili kroonika” (Glassner 2004: 184-187), kindlasti ka "Tukultī-Ninūrta I kroonika" (Glassner 2004: 186-187), mis kajastavad samuti assüürlaste ametlikku propagandat. See eepos oli koostatud kangelaslikus stiilis ning nagu Benjamin R. Foster õigesti märkis, "on narratiiv loodud pompöösses, heroilises stiilis" (Foster 2007: 20).

Kõik see on vaid preluudium Uus-Assüüria ajastule. Pärast Tukultī-Ninurta I surma käis Kesk-Assüüria riik alla ning Assüüria võimsus taastati alles 9. saj eKr.

\section{Uus-Assüüria ajastu (9-7 saj)}

Võib öelda, et 9-8 sajandiks eKr on välja kujunenud eraldi žanrina annaalid ja kroonikad. Need on üles ehitatud väga loogiliselt, kindla kaanoni järgi. Annaalid vaatlevad kuninga vallutusi ja tegusid ta valitsemisaastate kaupa ning üsna detailselt. Annaalide kirjutamist ja kroonikate koostamist õppisid assüürlased oma naabritelt - hetiitidelt ja babüloonlastelt. Esimesed teadaolevad annaalid

23 Tukultī-Ninurta is portrayed as a just and honorable king guided into invading Babylonia by treachery of his Babylonian counterpart, Kashtiliash who broke a long-standing treaty between the two nations. Tukulti-Ninurta calls upon Shamash, god of treaties, to witness the Babylonian's perfidy, and he assembles his forces. The Babylonian king, terrified, regrets his miseeds and seeks to avoid a direct conflict by various stratagems. Ultimately forced into an engagement, he flees for his life before the triumphant Assyrian army, which continues to Babylon itself and loots the city. 
ajaloos lõid juba Hetiidi suurkuningad II eelkristliku aastatuhande II poolel (del Monte 1993). Suurt mõju avaldas Assüüriale ka Babüloonia.

Niisiis arenes 9-7 saj lõplikult välja Uus-Assüüria ajalookirjutus. Vallutanud terve Lähis-Ida, hakkavad assüürlased "looma oma Lähis-Ida ajalugu”, kirjutades ajaloolisi sündmusi üles propagandistlikul eesmärgil. Kroonikad, annaalid ja raidkirjad on kõik mõeldud selleks, et ülistada assüürlasi ja nende valitsejat ning halvustada ja hirmutada vaenlasi. Siinkohal toome mõned näited Uus-Assüüria kuningate annaalidest ja raidkirjadest. Uus-Assüüria impeeriumi rajajaks peetakse Aššurnasirpal II (883-859) (vt lähemalt Liverani 1992). Tema annaalid on üsna huvitavad, kuid mõnes mõttes on neis näha päris palju kesk-assüüria mõjutusi ehk siis samu elemente, mida me näeme Salmanassar I, TukultīNinurta I või Tiglatpileser I raidkirjades. Käesoleva artikli piiratud mahu tõttu jääb Aššurnasirpal II raidkirjade ja annaalide vaatlemine mõnesse teise kirjutisse.

\section{Salmanassar III (858-824 eKr)}

Salmanassar III raidkirjades (nagu enamikus Uus-Assüüria kuningate raidkirjades) on peamiselt juttu küüditamisest, mõrvamisest ning andami saamisest eri piirkondadest, aga ka linnade hävitamisest ja põletamisest. See on assüüria raidkirjade või annaalide puhul üpris tavaline kirjeldus. Siinkohal mõned näited. Kui Salmanassar III liikus oma võimsa armeega Tīl-Barsipi piirkonnas üle Eufrati jõe, vallutas ta muuhulgas ka hulga väiksemaid kuningriike, alistas mitmeid hõime ja linnu, näiteks Paripa, Sūrūnu, TîlBašeri jt (Bunnes 1997: 17-28).

Ma tapsin maha palju nende [inimesi ja] viisin minema nendelt saadud saagi. Ma tegin maatasa, hävitasin [ja] põletasin ära 200 linna nende ümbruskonnas. (RIMA 3, Shalmaneser III A.0.102.2, col. II, rida 16-18, lk 18; vt ka tõlget Sazonov 2010b: 164). 
Veel ühe näitena toon Salmanassar III mõned vägivallateod, mida me loeme raidkirjas Shalmaneser III A.0.102.2. Seal on muuhulgas mainitud ka mitmete inimeste jõhkrat tapmist ning hulga kohalike vangistamist:

"Mina langetasin 700 nende sõjameest mõõgaga" (RIMA 3, Shalmaneser III A.0.102.2, col. II, lk 17, rida 3).

Samas raidkirjas hoopleb verejanuline despoot sellega, kui palju ta tappis Taia, Hazazu, Nulia ja Butāmu inimesi:

Liikudes eemale merest, vallutasin ma Taia, Hazazu, Nulia ja Butāmu linnad, mis kuuluvad patinealastele. Ma tapsin maha 2800 [nende] sõjameest [ja] viisin ära 14600 vangi (RIMA 3, Shalmaneser III A.0.102.2, col. II, lk 17, read 10-12; vt ka tõlget Sazonov 2010b: 164).

Ka kõik teised Assüüria kuningate raidkirjad on umbes samalaadsed. On muidugi mainitud ka paleede, linnade ja templite ehitamist, aga siiski on peamine rõhk sõjategevusel. Pärast Salmanassar III surma (824) käis Uus-Assüüria impeerium alla - nõrgenes ja oli kadumise äärel, kuna võimas Urartu riik ähvardas Assüüriat kogu aeg hävinguga. Kuid 8. saj teisel poolel taastas andekas väejuht Tiglatpileser III impeeriumi. Tema tekstidest alljärgnevalt juttu tulebki.

\section{Tiglatpileser III (745-728 eKr)}

Uus-Assüüria ajastu üks julmemaid valitsejaid, Assüüria võimsuse ja hiilguse taastaja oli andekas väepealik ja äärmiselt militaristlik kuningas Tiglatpileser III, kes paistis silma suure vallutaja ja reformaatorina, küüditamispoliitika ühe tähtsaima rakendajana. Tema ajal muutusidki küüditamine ja massimõrvamine assüürlaste ametlikuks riiklikuks poliitikaks. Oma raidkirjas kirjutab assüürlane, et võimsa endise suurriigi Urartu suurkuningas Sarduri olevat kuningas Tiglatpileser III enda sõnul lasknud jalga nii kiiresti kui võimalik: "Selleks, et päästa oma elu, põgenes Sarduri öösel, 
enne päikesetõusu lasi ta kiiresti jalga" (Tadmor 1994: 52, Ann. 17, tahvlid XIII-XIV, rida 10').

Selliste "vägitegudega" Tiglatpileser III muidugi ei piirdunud, vaid jätkas samas vaimus. Alljärgnevalt toome näite veel ühest kroonikast (Ann.6), mis on pärit Kalahi (Namrūdi) linnast:

1. [---] Hista, Harabisina, Barbaz’i, Tasa linna, Ulurusi jõge mööda üles, vallutasin ma ja võtsin 8650 inimest,

2. [---] 300 hobust, 600 eeslit, 1350 härga, 19000 lammast võtsin ma saagiks. Ma lammutasin, hävitasin ning põletasin tules.

3. [---] ning need linnad ma liitsin Assüüriaga. Ma ehitasin linnad taas üles ja paigutasin sinna inimesed minu poolt vallutatud maadest.

4. [---] Aššuri, mu isanda relvad seadsin üles sinna.

5. [---] Luqadanša, Quda, Elugia, Dania, Danziun'i, Ulay, Luqia, Abrania, (ja) Eusa

6. [---] ma võitsin. Ma tõin saagina kaasa 900 inimest, 150 härga, 1000 lammast, hobuseid, muulasid [ning] eesleid.

7. [---] nende linnu ma hävitasin ja laastasin ja põletasin maha. Muqania inimesed nägid tolmupilve minu [vägede] marsist, ja Uri linn [---]

(Tadmor 1994: 76, Ann. 5, lk 62, read 1-7; vt ka tõlget Sazonov 2010b: 160).

Tiglatpileser III teised annaalid on samalaadsed ning ega ka teiste Uus-Assüüria kuningate annaalid neist tegelikkuses väga erinegi. Alguses on sissejuhatus, kus mainitakse Assüüria kuningate titulatuuri ja genealoogiat ja ka tähtsamaid jumalaid nagu Aššur, Ištar, 
Šamaš jne, kes on andnud kuningluse kõnesolevale kuningale ja kes toetavad teda tema valitsemise jooksul, ükskõik millistes tegudes, olgu see sõda, ehitustööd, küüditamine vms (vt näiteks RINAP 4, Esarhaddon 57, lk 121, Col. i, read 1-13).

Tiglatpileser III raidkirju ja annaale on säilinud piisavalt palju ning neis toodud arvud on alati suured. Tigltapileser III annaalid ja raidkirjad on üles ehitatud loogiliselt, need on enamasti hästi loetavad, kuid näiteks annaalil nr 15 on algus täiesti kadunud kiilkirjatahvel on saanud tugevasti kannatada (Tadmor 1994: 72-73). Read 1-2 on täiesti hävinud, kolmandast reast on säilinud vaid mõned märgid, neljanda ja viienda rea algused ning lõpud on kadunud jne.

Suurim probleem on muidugi see, et mõned tekstid või tekstiosad on säilinud fragmentaarselt, osa ridu on kaduma läinud ja nende tekstide rekonstrueerimine on tihtipeale suur väljakutse ning raske ülesanne.

\section{Sennaherib (704-681)}

Üks maailma ajaloo jõhkramaid valitsejaid oli Uus-Assüüria kuningas Sennaherib ehk Sanherib (Brinkman 1973: 89-95), kes tappis ja küüditas tuhandeid babüloonlasi, aramealasi, kaldealasi, juute, elamlasi ja muid rahvaid.

Babüloonia sõjakäiku kirjeldab Sennaherib ühes oma kroonikas väga detailselt, hoobeldes ja uhkustades oma vallutustega ja tuues küüniliselt ära täpse küüditatute ja tapetute arvu.

Read 9-10: Oma isanda Aššuri jõuga ma piirasin sisse Kaldu maa [Babüloonia] 89 võimsat linna [ja] kindlust ja 620 väikest maakohta [küla] nende ümbruses, vallutasin ja rüüstasin. Urbi, Aramu ja Kaldu inimesi Urukis, Nippuris, Kišis, Hursagkalammas, Kuthas [ja] Sipparis üheskoos linnakodanikega, kes ennast tabada ei lasknud, viisin ma minema ja arvestasin saagi hulka (TUAT 2005: 69; vt ka tõlget Sazonov 2010b: 162). 
Read 12-16: Tagasitulekul vallutasin ma ühtviisi Tu'muna, Rihihu, Jadaqqu, Hamrānu, Hagarān'i, Nabatu [ja] Li'tau, [minule] mitte truualamlikke aramea [hõime]. 208000 inimest, suuri [ja] väikeseid, mehi [ja] naisi, 7200 hobust [ja] muula, 11073 eeslit, 5230 kaamelit, 80100 härga [ja] 800600 lammast viisin ma raske saagina Aššuri maale. Oma sõjakäigu jooksul sain ma Nabū-bēl-sumāte'lt, Hararatu linna valitsejalt, nii kulda, hõbedat, suuri mooruspuuvilju, eesleid, kaameleid, härgi ja lambaid kui ka tema kaalukaid andameid. Hirimmu linna elanikke, kangekaelseid [põikpäiseid] vastaseid, surusin maha [lõin maha] relvadega, mitte ühtegi järele jätmata. Nende laibad riputasin ma postidele ning ümbritsesin nendega linna (TUAT 2005; vt ka tõlget Sazonov 2010b: 162).

Sennaheribi annaalid on tavaliselt üsna detailsed, pikad, kirjeldavad ta sõjakäike ja loetlevad vallutatud maid, linnu, küüditatud ja tapetuid inimesi jne. See pole sugugi uudne Assüüria annaalide ja raidkirjade jaoks. See oli juba üsna levinud Uus-Assüüria ajastu alguses ja kohati leidub seda juba ka Kesk-Assüüria kuningate raidkirjades (vt näiteks Tukultî-Ninurta I tekste nagu RIMA 1, A.0.78.23, lk 272, read 27-30; RIMA 1, A.0.78.24, lk 275, read 23-25).

Isegi brutaalsete assüürlaste seas peeti Sennaheribi liiga karmiks ja lõpuks ta tapeti - tema pojad organiseerisid vandenõu ja tapsid oma isa 681. a. eKr.

Kroonikate, annaalide ja raidkirjade koostamine jätkus Assüürias ka hiljem kuni 7. saj lõpuni, mil Assüüria impeerium hävis. 7. saj eKr paistsid silma veel sellised viimased suurkujud UusAssüüria kuningate seast nagu Assarhaddon (680-669) (RINAP 4; Parpola, Watanabe 1988; Wiseman 1958) ja ta poeg Aššurbanipal (669-627), kuid olulisi muudatusi või uusi elemente nad sisse ei viinud. Seega pole Sennaheribi ja Assarhaddoni kroonikate, raidkirjade ja annaalide vahel erinevusi. Nii oma stiili, struktuuri kui kompositsiooni poolest on need üpris sarnased. 


\section{Kokkuvõte}

Nagu näha, on $c a 1700$ a jooksul (alates ca 2300 kuni $612 \mathrm{eKr}$ ) Aššuris (hiljem Assüüria) toimunud tohutu areng kõikides valdkondades - nii riikluse kui riikliku ideoloogia arengus, kirjanduses ja ajaloolise sisuga tekstide koostamisel (raidkirjad, annaalid, kroonikad). Alustame kas või sellest, et annaale Assüürias 2000 a paiku eKr veel polnud, raidkirju hakati kirja panema ca 2300 2200 eKr Akkadi impeeriumi mõjutustel, mille ülemvõimu alla kuulus ka Aššuri linn. Kuid need raidkirjad olid veel väga lühikesed ja primitiivsed ning tagasihoidlikud. Kui II eelkristliku aastatuhande alguses olid Assüürias vaid väga lakoonilised ja üksikud valitseja-raidkirjad tagasihoidliku titulatuuriga, kus polnud peaaegu üldse sõjaliste kampaaniate kirjeldusi, siis II eelkristliku aastatuhande lõpuks tekivad juba pikemad ja mahukamad raidkirjad, keerulisema struktuuriga, mis meenutavad veelgi hilisemaid Uus-Assüüria ajastu väga põhjalikke ja detailseid annaale, kus on üksikasjalikult ära märgitud valitseja titulatuur, genealoogia, valitseja sõjaretkede ja kampaaniate kirjeldus ning teised tegevused. Areneb ka kroonikate kirjutamine. Selles osas avaldasid Assüüriale suurt mõju naaberrahvad ja -riigid nagu Hetiidi impeerium, kust saigi annaalide kirjutamine alguse, aga ka babüloonlased ja hurriidid.

Peale välismõjude on Assüüria raidkirjade, annaalide ja kroonikate teke ning areng Assüüria riikluse arenguga, samuti Assüüria võimsuse ja prestiiži kasvuga ajavahemikul 14-7 saj eKr. Alguse sai kõik sellest, kui väike linnriigike Aššur, mis ei mänginud II eelkristliku aastatuhande I poolel mingit erilist rolli Mesopotaamia poliitikas, muutus juba 13. eelkristliku sajandi keskpaigaks tugevaks impeeriumiks. Just siis tekkisidki imperialistlik mõtlemisviis, kuningate pretensioonid ning soovid kontrollida tervet Lähis-Ida ehk siis laiemas mõttes maailma. I eelkristliku aastatuhande alguseks muutub Assüüria impeerium veelgi võimsamaks. Ka kuningavõim on siis muutunud piiramatuks. Assüüria kuningavõimu tugevnemise ja eduka ekspansiooniga kaasnesid propagandistlike 
tekstide hulga kasv ning nende areng, mh arenesid ka raidkirjad, mis kajastasid valitsejate tegusid. Tekkis tugev valitseja isikukultus, mis kulmineerus Uus-Assüüria ajastul. Lisaks kõigele leiab aset universalistlike ning muude väga auahnete tiitlite ja epiteetide kasutuselevõtt, nagu "universumi kuningas", "nelja ilmakaare kuningas", "kõikide inimeste päikesejumal", "isandate isand", "kuningate kuningas", "vürstide vürst" jne. Kuningas on jumaluste lemmik ja väljavalitu, tihtipeale ka peapreester, riigi ülemkohtunik ja sõjaväe juht jms. Assüüria kuningate pantokraatlikud soovid on hästi väljendatud kuninglikes raidkirjades, annaalides ning nende fraseoloogias ning ka kuninglikes tiitlites ja epiteetides.

Vanade lakooniliste raidkirjade asemel tulid Kesk-Assüüria ajastu lõpuks ja eriti Uus-Assüüria ajastu alguseks mahukad, pikad, kohati keerulisema sõnastusega, ilutseva stiili, tihtipeale valitsejate valitsemisaastate järgi dateeritud tekstid (näiteks annaalid) või siis muud samalaadsed tekstid (kroonikad, raidkirjad), mille eesmärk oli jäädvustada sündmusi, mis toimusid selle valitseja valitsemisajal ning samuti ülistada valitseja isikut ning ta dünastiat. Raidkirjad on tendentslikud, äärmiselt propagandistlikud, vahel täis faktide ja arvude moonutamist, mõnikord lausa fiktsioone, kuid samas saab neid siiski pidada ajaloolisteks tekstideks, kuna need on tihtipeale ainsad allikad Lähis-Ida teatud ajalooperioodide kohta.

Vaadates läbi terve hulga Uus-Assüüria ajastu kuningate raidkirju ja annaale, võib jõuda järeldusele, et need on üpris sarnased nii oma kompositsiooni, struktuuri kui sõnastuse poolest, kuid siiski on mõned erinevused ja omapära olemas. Muidugi toimub areng ja ligi 250 aasta jooksul õpitakse Uus-Assüüria riigis koostama ametlikke raidkirju, kroonikaid ja annaale üpris osavalt. Propaganda meetmed arenevad ja muutuvad täiuslikumaks. Annaalide struktuur põhineb ajalisel järgnevusel: tekst koostatakse valitseja valitsemisaastate järgi, ka kroonikates on see üpris tavaline.

Probleeme on selliste tekstide tõlkimiesl palju. Kuidas õigesti tõlkida akkadi keelest eesti keelde? Kuidas tõlkida nii, et sisu oleks täpne, aga ka stiil oleks arhailine ning arusaadav ja mitte konaralik? 
Mõned konkreetsed probleemid on järgnevad:

1) Kiilkirjatekstide dešifreerimine ja tõlkimine võib olla üsna keeruline ülesanne, eriti, kui tekst on saanud kannatada ning osa kiilkirjamärke pole loetavad ja kui tekst on kirjutatud keerulises ilukirjanduslikus keeles.

2) Tõlkimise seisukohast on kindlasti vaja vältida sõna-sõnalist otsetõlget, mis eesti keeles võib kõlada väga konarlikult ning jäädaisegi arusaamatuks.

3) Raidkirjade ja annaalide tõlkimise puhul on peamiseks sama reegel, mis kehtib ka ilukirjandusliku sisuga tekstide tõlkimisel, ehk - tuleb kasutada nii originaalilähedast lausestruktuuri kui võimalik, samas peab sihttekst olema lugejaskonna jaoks hästi arusaadav. Muidugi tuleb mõelda ka sihtkeele stiili peale, kuna see on oluline, sest täpne, aga konarlik tõlge võib põhjustada raskusi lugemisel ja arusaamisel. Näiteks üks tõsine probleem tõlkimisel akkadi keeles eesti keelde on lauseehitus, kuna akkadi keel on semiidi keel, mis erineb tugevasti soome-ugri keeltest. Eesti keeles pole grammatilist sugu, akkadi keeles on jne.

4) Tähtis on silmas pidada, et eri liiki tekstid nõuavad ka erisuguseid tõlkemeetodeid.

\section{Lühendid}

AfO - Archiv für Orientforschung.

AOAT - Alter Orient und Altes Testament, Veröffentlichungen zur Kultur und Geschichte des Alten Orients und des Alten Testaments. Kevelaer/Neukirchen-Vluyn, $1969 \mathrm{ff}$.

JCS - Journal of Cuneiform Studies.

JAOS - Journal of the American Oriental Society 


\section{Allikad}

al-Rawi, Farouk N. H. 2008. Inscriptions from the Tombs of the Queens of Assyria. - New Light on Nimrud.Proceedings of the Nimrud Conference $11^{\text {th }}-13^{\text {th }}$ March 2002. Eds. J. E.Curtis, H. McCall, D. Collon, L. al-Gailani Werr. London: British Institute for Study of Iraq in association with the British Museum, pp. 119-138.

Black, J. A., Cunningham, G., Ebeling, J., Flückiger-Hawker, E., Robson, E., Taylor, J., and Zólyomi, G. 1998 - The Electronic Text Corpus of Sumerian Literature (http://etcsl.orinst.ox.ac.uk/). Oxford.

Foster, B. R. 2005. Before the Muses. An Anthology of Akkadian Literature. Third Edition. Bethesda, Maryland: CDL Press.

Glassner, J.-J. 2004. Mesopotamian Chronicles. - Writings from the Ancient World. Atlanta: Society of Biblical Literature.

Grayson. A. K. 1975. Assyrian and Babylonian Chronicles.- Texts from Cuneiform Sources, Volume V. Eds. A. L. Oppenhein, M. Civil, E. Reiner, E. Sollberger. Locust Valley, New York: J.J. Augustin Publisher.

Grayson, A. K. 1976. Assyrian Royal Inscriptions, Volume II, Part 2, From Tiglath-pileser I to Ashur-nasir-apli II, Records of The Ancient Near East. Ed. H. Goedicke. Wiesbaden: Harrassowitz.

RIMA 1 = Grayson, A. K. 2002. Assyrian Rulers of the Third and Second Millennia BC (to $1115 \mathrm{BC}$ ). - The Royal Inscriptions of Mesopotamia, Assyrian Periods, Volume 1. Toronto, Buffalo, London: University of Toronto Press.

RIMA 3 = Grayson, A. K. 1996. Assyrian Rulers of the Early Fisrt Millennium BC II (858-745 BC). - The Royal Inscriptions of Mesopotamia, Assyrian Periods, Volume 3. Toronto, Buffalo, London: University of Toronto Press.

RINAP 4 = Leichty, E. 2011. The Royal Inscriptions of Esarhaddon, King of Assyria (680-669). - The Royal Inscriptions of the Neo-Assyrian Period, Volume 4. Winona Lake, Indiana: Eisenbrauns.

ITN = Weidner, E. 1970. Die Inschriften Tukulti-Ninurtas I. und seiner Nachfolger, Archiv für Orientforschung, Beiheft 12. Hrsg. E.Weidner. Osnabrück: Biblio Verlag.

Machinist, P.B. 1978. The Epic of Tukulti-Ninurta I. A Study in Middle Assyrian Literature. A Dissertation Presented to the Faculty of the Graduate School of Yale University in Candidacy for the Degree of Doctor of Philosophy. Käsikiri. 
Parpola S., Watanabe, K. 1988. Neo-Assyrian Treaties and Loyalty Oath. - State Archives of Assyria, Volume 2. Helsinki: Helsinki University Press.

Rasmussen, N. 1897. Salmanasser den II's Indskrifter, Kileskrift, Transliteration og Translation, samt Commentar til Monolith-Inskriften. Col. 1. Kjøbenhavn: I Komssion hos Boghandler Kayser, Nielsen \& Lydiches Bogtrykkeri.

Stein, P. 2000. Die mittel- und neubabylonischen Königsinschriften bis zum Ende der Assyrerherrschaft, Grammatische Untersuchungen. - Jenaer Beiträge zum Vorderen Orient 3. Wiesbaden: Harrassowitz Verlag.

Tadmor, H. 1994. The Inscriptions of Tiglath-pileser III King of Assyria, Critical Edition, with Illustrations, Translations and Commentary. Jerusalem: The Israel Academy of Sciences and Humanities.

TUAT 2005 = Texte aus der Umwelt des Alten Testaments 2005. Neue Folge, Band 2, Staatsvertäge, Herrscherinschriften und andere Dokumente zur politischen Geschichte. Hrsg. B. Jankowski, G. Wilhelm. Gütersloh: Güterslohwer Vergshaus.

Wiseman, D. J. 1958. The Vassal-Treaties of Esarhaddon, Iraq XX, Part I. London: The British School of Archaeology in Iraq.

\section{Kirjandus}

Aboud J. 1994. Die Rolle des Königs und seiner Familie nach den Texten von Ugarit. - Forschungen zur Anthropologie und Religionsgeschichte, Band 27. Münster: Ugarit-Verlag.

Artzi, P. 1978. The Rise of the Middle-Assyrian Kingdom according to El-Amarna Letters 15\&16. A Contribution to the Diplomatic History of Ancient Near East in the mid-second Millenium B.C.E. - Bar-Ilan Studies in History. Ed. P. Artzi. Ramat-Gan: Bar-Ilan University Press, pp. 25-41.

Brinkman, J. A. 1973. Sennacherib’s Babylonian problem: an interpretation. JCS no 25, pp. 89-95.

Brinkman, J. A. 1997. Unfolding the Drama of Assyrian Empire. - Assyria 1995, Proceedings of the 10th Anniversary Symposium of the Neo-Assyrian Text Corpus Project, Helsinki, September 7-11, 1995. Eds. S. Parpola, R. M. Whiting. Helsinki: The Neo-Assyrian Text Corpus Project, pp. 1-16. 
Borger, R. 1961. Einleitung in die assyrischen Königsinschriften. Teil 1, Das zweite Jahrtausend v. Chr. Leiden, Köln: Brill.

Bunnes, G. 1997. Til Barsib under Assyrien Domination: A Brief Account of the Melbourne University Excavations at Tell Ahmar. - Assyria 1995, Proceedings of the 10th Anniversary Symposium of the Neo-Assyrian Text Corpus Project, Helsinki, September 7-11, 1995. Eds. S. Parpola, R. M. Whiting. Helsinki: The Neo-Assyrian Text Corpus Project, lk 17-28.

Cancik-Kirschbaum, E. 2003. Die Assyrer: Geschichte, Gesellschaft, Kultur. München: Verlag C. H. Beck.

del Monte, G.F. 1993. L'annalistica ittita. - Testi del Vicino Oriente antico 4. Letterature dell'Asia Minore a cura di Fiorella Imparati. Brescia: Paideia Editrice.

Faist, B. 2001, Der Fernhandel des assyrischen Reiches zwischen dem 14. und 11. Jh. v.Chr. - AOAT 265, Veröffentlichungen zur Kultur und Geschichte des Alten Orients und des Alten Testaments. Hrsg. M. Dietrich, O. Loretz. Münster: Ugarit-Verlag.

Foster, B.R. 2007. Akkadian Literature of the Late Period. Münster: Ugarit-Verlag.

Harrak, A. 1987. Assyria and Hanigalbat. A Historical Reconstruction of Bilateral Relations from the Middle of the Fourteenth to the End of the Twelfth Centuries B.C. Texte und Studien zur Orientalistik, Band 4. Hildesheim, Zürich, New York: Georg Olms Verlag.

Heinhold-Krahmer, S. 1988. Zur Salmanassars I. Eroberungen im Hurritergebiet. - AfO 35, pp. 79-104.

Holloway S.W. 2002. Aššur is King! Aššur is King! Religion in the Exercise of Power in the Neo-Assyrian Empire. - Eds. B. Halpern, M. H. E. Weippert, Th. Ph. J. Van den Hout, I. Winter, Volume 10. Leiden, Boston, Köln: Brill.

Jankovskaja 1968 = Янковская, Н. Б. Клинописные тексты из Кюль-тепе из собрания СССР (письма и документы торгового объединения в Малой Азии XIX в. до н.э.). Автографические копии, транскрипция перевода, вводная статья, комментарий и глоссарий Н. Б. Янковской. - Памятники Письменности Востока XIV. Москва: Издательство Наука 1968.

Klengel, H. 1961. Tukulti-Ninurta I, König von Assyrien. - Das Altertum 7, pp. 67-77.

Lambert, W. G. 1974. The Reign of Aššurnasirpal II and Shalmaneser III: An Interpretation. - Iraq 36, pp. 103-109. 
Lambert,W. G 1976. Tukultī-Ninurta I and the Assyrian King List. - Iraq 38, pp. 85-94.

Lambert, W. G. 2004. The Enigma of Tukultī-Ninurta I. - Studies on the History of Assyria and Babylonia in Honor of A. K. Grayson. Toim. G. Frame, L.Wilding. Nederlands Instituut Voor Het Nabije Oosten, pp. 197-202.

Liverani, M. et al. 1992. Studies on the Annals of Ařšurbanipal II, Volume II. Topographical Analysis. La Sapienza: Universita di Roma.

Mayer, W. 1995. Politik und Kriegskunst der Assyrer. - Abhandlungen zur Literatur Alt-Syrien-Palästinas und Mesopotamiens. Band 9. Hrsg. M. Dietrich, O. Loretz. Münster: Ugarit-Verlag.

Müller, K. Fr. 1937, Das Assyrische Ritual, Teil I. Texte zum assyrischen Königsritual. - Mitteilungen der Vorderasiatisch-Aegyptischen Gesellschaft (E.V.), 41. Band, 3. Heft, Lepzig: J.C. Hinrichs Verlag.

Nemirovski 2008 = Немировский, А. А. 2008. К истории хетто-ассирийских отношений в конце XIII - начале XII в. до н.э - Вестний Древней Истории 2, с. 3-24.

Oded, B. 1979. Mass Deportations and Deportees in the Neo-Assyrien Empire. Wiesbaden: Dr. Ludwig Reichert Verlag.

Olmstead, A.T. 1917. Tiglath-Pileser I and his wars. - JAOS 37, pp. 169-185.

Röllig W. 1967. Die Glaubwürdigkeit der Chronik P. - Heidelberger Studien zum Alten Orient. Wiesbaden: Otto Harrassowitz, pp. 173-184.

Sazonov, V. 2006. Arad-Ahhešu kiri Aššurbanipalile. - Tuna 1, lk 80-87.

Sazonov, V. 2010a. Die Königstitel und -epitheta in Assyrien, im Hethiterreich und in Nordsyrien (Ugarit, Emar, Karkemiš) in der mittelassyrischen Zeit: Strukturelle Gemeinsamkeiten, Unterschiede und gegenseitige Beeinflussung. Dissertationes Historiae Universitas Tartuensis 21. Tartu: Tartu Ülikooli Kirjastus.

Sazonov, V. 2010b. Küüditamispoliitika kui muistne tava Uus-Assüüria impeeriumis 9.- 7. sajandini eKr. - Mäetagused 44, lk 153-174.

Sazonov, V. 2011. Die mittelassyrischen, universalistischen Königstitel und Epitheta Tukulti-Ninurtas I (1242-1206). - Identities and Societies in the Ancient East-Mediterranean Regions: Comparative Approaches, Henning Graf Reventlow Memorial volume. Acta Mediterranea et Oreintalia, Band 1, Alter Orient und Altes Testament Band 390/1. Hrsg. Th. R. Kämmerer. Münster: Ugarit-Verlag, pp. 235-276. 
Solovjova, Nemirovski 2007 = С. С. Соловьева, А. А. Немировский, Глава 11. Месопотамия во II тысячелетии до н.э. Преобладание Вавилона. - История Древнего Востока, издание третье, переработанное и дополненное. Ред. В. И. Кузищин. Москва: Высшая школа 2007, с. 128-143.

Veenhof, K. R. 1972. Aspects of Old Assyrian Trade and Its Terminology. Leiden: Brill.

Weidner, E. 1939-1941. Studien zur Zeitgeschichte Tukultī-Ninurtas I. - AfO13, pp. 109-124.

Yamada, Sh. 2000. The Construction of the Assyrian Empire. A Historical Study of the Inscriptions of Shalmaneser III (859-824 BC) relating to His Campaigns to the West. Culture and History of the Ancient Near East, volume 3. Eds. B. Halpern, M. H. E. Weippert, Th. P. J. van den Hout, I. Winter. Leiden, Boston, Köln: Brill.

\section{Summary}

\section{Some Comparative Remarks Concerning Middle- and Neo-Assyrian Royal Inscriptions, Chronicles and Annals (ca 1500-612 BCE) and Problems Related to Translation of This Kind of Texts}

The current article is dedicated to the analysis of some Middleand Neo-Assyrian chronicles, annals and royal inscriptions and some aspects and problems related to the translation of such texts. This overview gives also a short introduction into Assyrian history from its beginning until the end of Neo-Assyrian Empire in 612 BCE and into "historical" or "pseudo-historical" texts (royal inscriptions, chronicles etc.) and their development during the II millennium BCE and the first half of the I millennium BCE. The author concentrates on some aspects of Babylonian, Hittite and other influences on Assyrian writing in the form of chronicles, inscriptions and annals. Some questions of royal propaganda are 
also addressed, such as textual representation of royal titles, military conflicts, deportation of people, looting of cities, etc.

The second part of the article focuses on some important and difficult problems a translator faces when translating such texts, such as deciphering and interpretation of cuneiform texts (texts may be razed, have lacunas, they are often too fragmentary, problems arise with understanding terms, some difficult grammatical forms, etc.).

Key words: Assyria, chronicles, inscriptions, annales, ideology, kings, propaganda, translation problems 


\section{Grammatiline sugu - tõlkija sõber või vaenlane?}

\section{Sirje Kupp-Sazonov}

doi:10.7592/PS/28-4kupp_sazonov

Teesid: Käesoleva artikli eesmärk on peatuda mõningatel tõlkeraskustel, mis on tingitud sellest, et vene keeles eksisteerib grammatilise soo kategooria ja eesti keeles see puudub. Probleemsed kontekstid võib jagada kolme gruppi: 1) venekeelsed он/она ja eestikeelne tema; 2) venekeelsed он/она ja eestikeelne see; 3) isikuid tähistavad nimisõnad.

Ka eesti keeles on mõned vahendid, mis grammatilise soo kategooria puudumist kompenseerivad, näiteks:

1) sufiksid: -nna (kuninganna), -tar (krahvitar);

2) eesliide nais- (naissportlane);

3) liitsõnad, milles üks sõna viitab isiku soole (kasuõde ja kasuvend).

Eraldi teemana on vaatluse all sõnad, millel juba originaalis on lisaks soo märkimisele ka eesmärk väljendada negatiivset hinnangut.

Märksõnad: grammatiline sugu, eesti keel, vene keel, tõlkimine, asesõnad, nimisõnad.

\section{Sissejuhatus}

Grammatiliste raskuste ja sellest tulenevalt transformatsioonide teema on tõlketeoorias ning -praktikas viimastel aastatel muutunud aina olulisemaks. Üheks põhjuseks võib pidada seda, et nii keeleteadlased kui ka tõlkespetsialistid on jõudnud järeldusele, 
et grammatika ei ole lihtsalt rangete ja igavate keelereeglite ning -normide kogum, vaid tegelikkuses võimaldab grammatika samasugust loomingulist lähenemist keelele nagu leksika (Remtšukova 2005: 23). Teisest küljest on selge - mida olulisemad erinevused on kahe keele grammatiliste süsteemide vahel, seda suuremate väljakutsetega peab tõlkija kokku puutuma. A. Lange on kirjutanud: "Tõlkimine tähendab muu hulgas ühe keele grammatika väljavahetamist teise keele grammatika vastu, ja kalkuleerida saab siin vähe" (Lange 2008: 23). Vene ja eesti keel on oma grammatika poolest vägagi erinevad, näiteks käänete arv (eesti $k$ neliteist ja vene $\mathrm{k}$ kuus), ajavormide süsteem (eesti k neli ajavormi, millest kolm on mineviku vormid ning puudub grammatiline tuleviku vorm, vene $\mathrm{k}$ kolm) jne.

Käesolevas artiklis keskendutakse mõningatele tõlkeraskustele, mis on tingitud vene keeles olemas olevast grammatilise soo kategooriast, samal ajal kui eesti keeles see puudub. Tõlke seisukohast on sageli oluline ja ühtlasi ka kõige keerulisem anda edasi just elusolendite soolist kuuluvust, elutute objektide puhul mängib grammatiline sugu tõlkes tunduvalt väiksemat rolli, vähemalt mis puudutab vene-eesti tõlget. Kuid mitmed eksperimendid on näidanud, et grammatiline sugu võib kujundada kõnelejate tundeid ja assotsiatsioone neid ümbritsevate objektide suhtes, nagu on kirjutanud mh nt iisraeli keeleteadlane Guy Deutscher. 1990. aastatel olevat psühholoogid, kes võrdlesid hispaania ja saksa keeles sõnu, mis ühes keeles olid vastavalt nais- ja teises meessoost, leidnud, et inimesed kirjeldasid objekte vastavalt nende soole. Näiteks sõna sild, mis on hispaania keeles meessoost el puente, oli hispaanlaste jaoks tugev, sakslaste die Brücke aga elegantne ja sale (Deutscher 2010).

Materjali analüüsist selgub, et peamised takistused tõlkimisel tekivad kolmel juhul:

1) venekeelsed asesõnad он/она ja eestikeelne tema;

2) venekeelsed asesõnad он/она ja eestikeelne see;

3) mitmesuguseid isikuid ja ameteid tähistavad nimisõnad.

Näited pärinevad vene ilukirjanduslikest tekstidest ja nende tõlgetest eesti keelde. Enne analüüsi oleks aga kohane vaadata põgusalt üle peamised seisukohad grammatilise soo osas vene keeles. 


\section{Grammatiline sugu vene keeles}

Sookategoorial on vene keeles keskne koht nimisõna grammatilises süsteemis ja seda kahel põhjusel. Esiteks - grammatiline sugu määrab ära omadus-, tegu- ja asesõnade ühildumise nimisõnaga. Teiseks - just grammatilise soo alusel jagunevad nimisõnad käändkondadesse.

Seetõttu kuuluvad peaaegu kõik nimisõnad (sellest tulenevalt ka omadus- ja asesõnad) vene keeles ühte kolmest soolisest grupist: mees-, nais- ja kesksugu. Peab silmas pidama, et mitte alati ei toimu see bioloogilise või sotsiaalse jaotuse järgi, sest vene keeles on sugu ka nendel sõnadel, mis tähistavad elutuid objekte. Kuigi mitmed silmapaistvad keeleteadlased, teiste hulgas ka M. Šeljakin, on arvamusel, et grammatilise soo kategooria väljakujunemise ajaloolisel perioodil tingis ühele või teisele elutule objektile konkreetse soo omistamise ikkagi mingisugune eseme tunnustega seotud assotsiatsioon, ei pruukinud see alati olla semantiline (Šeljakin 2002: 51). A. Aksjonov eristab grammatilise soo motiveeritust ja mittemotiveeritust, elutute objektide sooline kuuluvus on mittemotiveeritud (sest puudub seos grammatilise soo ja eseme olemuse vahel), samal ajal kui elusolendite oma on motiveeritud, kui mõned erandid välja arvata (Aksjonov 1984: 17-18).

Eksisteerib grupp sõnu, mida olenemata oma soolisest kuuluvusest võib kasutada nii naiste kui meeste kohta, kuid nende ühildumisel omadussõnade või tegusõnadega tuleb arvestada siiski sõna sooga. Nende sõnade hulka kuuluvad näiteks sellised meessoost lekseemid: человек 'inimene', ребенок 'laps', подросток 'teismeline', враг 'vaenlane', классик 'klassik' jms. "Kõikides nendes sõnades on sugu neutraliseeritud: need tähistavad isikuid ilma soolise eristamiseta ning ei võimalda süntaktilist naissoo väljendamist (ei saa öelda: ${ }^{\star}$ Человек пришла, isegi kui viitame naissoost isikule) (Šeljakin 2001: 33). Võrdselt naiste ja meeste kohta saab kasutada ka kolme naissoost nimisõna: персона 'persoon', личность 'isiksus', особа 'isik', need sõnad ühilduvad süntaktiliselt omakorda ainult naissooga. 
Lisaks eelpool mainitule on vene keeles mõned sõnad, millel üldse puudub sooline kuuluvus ja mida võib kasutada nii mees- kui naissoost isikute kohta, näiteks: сирота 'orb', пьяница 'joodik', соня 'unimüts, коллега 'kolleeg' jt. Isiku soo konkretiseerimiseks kasutakse vastavast soost omadussõna, näiteks хороший коллега 'hea meeskolleeg' ja хорошая коллега 'hea naiskolleeg'. Sellest hoolimata tuleb tunnistada, et üldise iseloomuga väidetes, kus ei viidata konkreetsele isikule, on ikkagi eelistatud kasutuseks meessoost variant (Nikunlassi 2000: 776). Näiteks: Каждыı̆ сupoma хочет, чтобы у него была большая семья. 'Iga orb tahab, et tal oleks suur perekond'. Üldine tähelepanek on veel see, et sellised sõnad väljendavad sagedamini negatiivseid kui positiivseid omadusi (Vastšenko 1984: 63).

Üldiselt ollakse tänapäeva vene keeleteaduses seisukohal, et lingvistiline meessoo kategooria on markeerimata, "see on seletatav asjaoluga, et paljud professionaalsed tegevusalad ja teised ühiskondlikud valdkonnad olid varem üldiselt meessoost isikute privileegiks, aga pärast teatud ühiskondlikke muutusi hakkas grammatiline meessoo vorm viitama ka naissoost isikutele. Siiski pole alati õigustatud pidev meeste ja naiste vastandamine töö, ühiskondliku tegevuse ja haridusega seotud ametlikes dokumentides. Seetõttu on ametlikus stiilis kinnistunud peamiselt meessoo vormi kasutamine neutraliseeritud funktsioonis" (Šeljakin 2001: 32).

Siiski ei ole ka vene keel ja kultuur jäänud puutumata sellistest ülemaailmsetest nähtustest nagu feminism või meeste ja naiste võrdõiguslikkuse küsimused. Seetõttu on tänapäeva vene keeles laialt levinud võtteks märkida naissugu süntaktiliselt, näiteks: Bpaч пришла, harvemini хорочая врач (Šeljakin 2001: 32). Kõnealune nähtus on tingitud ka veel asjaolust, et sageli on ameteid märkivate nimetuste naissoost vormid markeeritud, kõnekeelsed ja mõnikord negatiivse konnotatsiooniga, näiteks инженерша 'naisinsener', химичка 'naiskeemik', секретарша 'naissoost sekretär'.

Tuleb mainida veel seda, et eelmise sajandi 60. aastatel leidsid mõned keeleteadlased, nende hulgas ka A. Zaliznjak (1967: 80), et tegelikkuses võiks vene keeles eristada isegi veel üht grammatilist sugu, tema kasutas terminit "paarissugu" (vene k nарныци род, 
ing. k pair gender). Põhjuseks oli see, et traditsiooniline nimisõnade vastandumine sookategooria alusel ei võimaldanud hõlmata paraku kõiki nimisõnu. Sõnu, millel puudub ainsuse vorm, mis kuuluvad Pluralia tantum-sõnade hulka, ei eristata grammatilise soo kategooria alusel. Selline olukord näis A. Zaliznjakile aga selgelt vastuolulisena, sest üldine reegel kinnitab, et kõikidel nimisõnadel on üheks tunnuseks grammatiline sugu. ${ }^{24}$ Paarissoo nähtuse aktsepteerimine võimaldaks selle vasturääkivuse likvideerida. Termin kannab sellist nimetust, sest enamjaolt kuuluvad Pluralia tantum -sõnade hulka nimisõnad, mis tähistavad kahest osast koosnevaid objekte, näiteks брюки 'püksid', ножницы 'käärid' jms, kuid mitte ainult, näiteks lekseemid: дрожжи 'pärm', сливки 'koor' ei sisalda sellist tähendust. Siiski peab tõdema, et suurem osa tänapäeva grammatikateatmikke ja õpikuid ning ka keeleteadlasi ei ole seda seisukohta omaks vôtnud ning räägivad vene keele grammatikas siiski vaid kolmest soost.

Nagu juba eelpool öeldud, ei põhjusta vene-eesti tõlke seisukohast elutute objektide grammatiline sugu erilisi raskusi. Käesolevast analüüsist jäävad kõrvale ka leksikaalset sugu väljendavad sõnad nagu мать 'ema', сың 'poeg', nemyx 'kukk' jne, sest viide soole esineb neis enamasti mõlemas vaadeldavas keeles ja seetõttu saab neid tõlkida probleemideta. M. Šeljakin väidab, et loomade nimetused on hoolimata oma grammatilisest soost mittemarkeeritud, need võivad viidata nii looma soole või ka olla üldiseks loomaliigi nimetuseks, selle poolest erinevad need sõnad isikuid tähistavatest nimetustest (Šeljakin 2001: 33).

\section{Venekeelsed asesõnad он/она ja eestikeelne tета}

Pöörame tähelepanu esimesele raskusele: venekeelsed asesõnad $o H /$ она ја eestikeelne tema.

24 Sõnad cupoma (orb) ja пяница (joodik) on üheaegselt nii mees-, kui naissoost sõnad, samal ajal kui sõnal брюкu (püksid) puudub grammatiline sugu sootuks. 
Olgu öeldud, et kuigi eesti keeles eksisteerib sõna temake, kasutatakse seda enamjaolt siiski vaid ilukirjanduses. "Eesti keele seletavas sõnaraamatus" seisab, et vorme temake ja temakene kasutatakse kurameeriva naisisiku kohta, tähenduses 'kallim, pruut' (EKSS 2009). Sellest võib järeldada, et temakest ei saa kasutada kontekstis, kus on vaja viidata lihtsalt naissoost isikule. Tegelikult peab see paika vaid osaliselt, on selge, et üheski ametlikus dokumendis ei saa seda vormi tõesti kasutada, kuid ilukirjandus nii rangeid piiranguid siiski ei kehtesta, kuigi sõna täielikust neutraalsusest ei saa me rääkida muidugi mitte mingil juhul. Näiteks keeletoimetaja Maris Makko on märkinud: "Muidugi, ilukirjanduse tõlkijatele ongi paras pähkel, kuidas eristada tihedas tekstis he'sid ja she'sid, on'e ja ona'sid. Millalgi püüti naistegelase kohta rakendada pisendusliitega moodustatud tuletist "temake", kuid sellel on naeruvääristav varjund.” (Makko 2011).

Näide (1) pakub võimalust võrrelda eri tõlkevariante. Venekeelne tekst pärineb filmist "D’Artagnan ja kolm musketäri”, seal on stseen, kus Rochefort tuleb kardinal Richelieu'le teatama, et kuninganna kohtus Buckinghami hertsogiga, aset leiab järgmine venekeelne dialoog:

(1) Richelieu: Так что же, Рошфор?

Rochefort: Они виделись, Ваше Преосвященство.

Richelieu: Кто это “они”?

Rochefort: Он и она.

Richelieu: Кто это “он и она”?

Rochefort: Королева и герцог.

Meid huvitab selles näites just asesõnade $о н$ ја она kasutamine ning tõlkimine eesti keelde. Artikli autor on kohanud kolme eri tõlkevarianti. Esimene versioon pärineb filmist, mida kunagi näitas Kanal 2. Selles eestikeelses variandis oli tõlkija valinud asesõnad tema ja temake. Kuna vähemalt Alexander Dumas'i teoste kohaselt olid Buckinghami hertsogi ja Prantsusmaa kuninganna vahel romantilised tunded, siis sellesse konteksti võiks sõna temake isegi sobida, eriti kui lähtuda eelpool mainitud "Eesti keele seletava sõnaraamatu" tähendusest. 
Teine tõlkeversioon pärineb firma Video Leader välja antud DVD-lt. Tõlkija on venekeelsed asesõnad eesti keelde pannud sõnadega meesterahvas ja naine. Ka sellele versioonile ei saa midagi ette heita. Artikli autorile näib vaid, et parema kõla saavutamiseks oleks tõlkija võinud eelistada sarnase struktuuriga sõnu, ehk siis mees ja naine või meesterahvas ja naisterahvas.

Kolmanda tõlkeversiooni võib leida firma DVD Sonatiin OÜ toodetud DVD-lt. Selles versioonis on tõlkija otsustanud loobuda venekeelse soolise vastandamise edasiandmisest eesti keeles. Venekeelsed asesõnad tõlgitakse eesti keelde lekseemiga nemad.

Üldiselt tundub, et vormi temake kasutatakse tõlkes kõige vähem (artikli autor ei ole viinud läbi spetsiaalset statistilist uurimust, väide tugineb piiratud hulga tekstide tõlgete analüüsil). Siiski ei saa öelda, et temake oleks tõlkevariandina täiesti kõrvale jäetud. Lisaks vene keelest tõlkimisele pöörduvad tõlkijad selle variandi poole ka näiteks ingliskeelse originaali puhul. Vt näited (2), (3) ja (4).

(2) Если бы Варвара не знала совершенно точно, что в этом кабинете молодой мужик руководит делами огромного холдинга, она бы подумала, что «гнезды шкоржанки» принадлежит ну, скажем, экзальтированной и утонченной содержательнице журнала «Он и Она». (Т. Ustinova)

Kui Varvara poleks kindla peale teadnud, et selles kabinetis juhatab noor meesterahvas suure ettevõtte äriasju, võinuks ta arvata, et "põldrüüdi pesa" kuulub näiteks ajakirja Tema ja Temakese eksalteeritud ja rafineeritud kirjastajale.

(3) Да, да, кино разрешает игру, разрешает легкость... страсть... брызги шампанского... он и она... мужчина и женщина... ночное море... (L. Ulitskaja)

Jaa-jaa, film lubab mängu, lubab kergust... kirge... šampanjapritsmeid... tema ja temake... mees ja naine... öine meri...

(4) The Cook, The Thief, His Wife \& Her Lover (Eesti kultuurisündmuste kalender)

Kokk, varas, tema naine ja temakese armuke 
Analüüsides ilukirjanduslikke tõlkeid, näib üldiselt, et kõige sagedasem tõlkevõte on asendada meessoost asesõna nimisõnadega mees, noormees, poiss ja naissoost vastavalt naine, neiu jne. Mainitud tõlkevõte on igati õigustatud, probleemiks võib see osutuda vaid siis, kui originaali autor ei anna oma tekstis informatsiooni näiteks tegelase vanuse kohta, sellisel juhul võib tõlkijal olla raske otsustada, kas tõlkida näiteks asesõna $o H$ vastega mees, noormees või poiss jne. Vaatleme järgmisi näiteid (5), (6), (7) ja (8), kus asesõnad on tõlgitud nimisõnadega.

(5) Он подошел, поклонился, сел рядом. (B. Akunin) Mees tuli lähemale, kummardus ja istus kõrvaltoolile.

(6) Она успела посидеть не только у себя на постели (именно так, как вообразил Извеков), она двадцать раз перешла с места на место, присаживаясь и опять поднимаясь, подбегая то к двери, то к окну, вслушиваясь в стоны и присвисты вьюги и боясь не отличить от них стук Кирилла. (K. Fedin)

Neiu jõudis veidi istuda oma voodil (just nii, nagu kujutas ette Izvekov), käia kakskümmend korda ühest kohast teise, võtta istet ja tõusta jälle, kord joosta ukse juurde, kord akna juurde, kuulatades teraselt tuisu oigeid ja vilistamisi ning kartes, et ei eralda nendes Kirilli koputust.

(7) - Очень, - честно ответил он, и она соскочила, оставив его стрелу невыпущенной. (L. Ulitskaja)

"Väga meeldid," vastas ta ausalt, ja naine hüppas maha, jättes tema noole välja laskmata.

(8) Я почему-то услышал сейчас ту музыку, и как танцевали двое - он и она, пастух и пастушка. (V. Astafjev)

Miskipärast kuulsin ma praegu toda muusikat, ja kuidas nad kahekesi tantsisid, - tüdruk ja poiss, karjapoissi-karjapiigat meenus talle.

Muidugi ei ole haruldased ka need juhud, kui asesõna tõlgitakse asesõnaga, kuid seda tehakse tavaliselt ikkagi ainult siis, kui kon- 
tekstist on selgelt aru saada, kellele asesõna viitab. Tegelikult on päris sagedased ka need olukorrad, kui tõlkija ühendab tõlkes originaali kaks asesõna (он ја она) üheks sõnaks nemad. Asesõnaga tõlkimist illustreerivad näited (9), (10) ja (11).

(9) Поехала эта Юлия Петровна в горы... Была отличная погода! Впереди едет она со своим проводником, немножко позади - я. Отъехали мы версты три-четыре, вдруг, понимаешь ты, Васичка, Юлия вскрикивает и хватает себя за грудь. Ее татарин хватает ее за талию, иначе бы она с седла свалилась... Я со своим проводником подъезжаю к ней... (A. Tšehhov)

Sõitis see Julia Petrovna mägedesse... Oli oivaline ilm! Ees sõidab tema oma teejuhiga, veidi tagapool - mina. Sõitsime versta kolm-neli eemale, äkki, kas mõistad, Vasjake, Julia karjatab ning võtab endal rinnust kinni. Tema tatarlane haarab tal piha ümbert kinni, muidu oleks ta sadulast maha kukkunud... Mina oma teejuhiga sõidan tema juurde...

(10) Пилат сказал, что он разобрал дело Иешуа Га-Ноцри и утвердил смертный приговор. (M. Bulgakov)

Pilatus ütles, et ta vaatas läbi Ješua Ha-Notsri süüasja ja kinnitas surmaotsuse.

(11) В первое время, когда я в таких случаях вынимал свой редкий рубль, он и она с такой настойчивостью всучивали мне его назад, что вскоре я перестало бращать на это внимание, ибо никчему так быстро не привыкает человек, как к дармовому угощению. (F. Iskander)

Alguses, kui ma sellistel juhtudel oma ainsa rubla välja võtsin, toppisid nad mõlemad selle nii visalt mulle pihku tagasi, et ma varsti seda enam tähelegi ei pannud, sest inimene ei harju mitte millegi muuga nii kiiresti kui tasuta kostitamisega.

Neljas tõlkevõte, mida sellistes eri keelte võimalustest tingitud keerulistes olukordades kasutatakse, on asesõnadele tõlkes vastetena hoopis tegelaste nimede kasutamine, näited (12) ja (13). On selge, 
et sellist strateegiat on võimalik rakendada vaid siis, kui tegelaste nimed on juba teada. Kui autor on otsustanud mingis teksti osas (näiteks teose alguses) oma tegelase jätta anonüümseks ja viidata talle vaid asesõnaga, siis ei ole tõlkijal õigust oma tekstis samas lõigus tegelase nime kasutada ning sellega autori taotlusi hävitada. Peab ütlema, et analüüsitud materjalis ei esinenud sellist tõlkija eksimust kordagi.

(12) - Лежи тихо, - сказал он, и она ничего не поняла.

(T. Ustinova)

"Lama vaikselt," ütles mees ja Varvara ei saanud millestki aru.

(13) - Ты умеешь готовить? - удивился он, и она услышала, как он усмехнулся. (T. Ustinova)

"Sa oskad süüa teha?" imestas Ivan ja Varvara kuulis, kuidas ta muigas.

\section{Venekeelsed asesõnad он/она ja eestikeelne see}

Teine problemaatiline olukord tõlkes on venekeelsed asesõnad он/она ја eestikeelne see. Vene keele grammatilise soo kategooria annab keelele selle eelise, et on võimalik koostada küllaltki pikki lauseid, kus mingisugust eset või nähtust mainitakse nimetusega vaid korra ja edaspidi saab sellest esemest või nähtusest rääkides kasutada vaid vastavast soost asesõna, vt näide (14).

(14) Книга лежит на столе, её подарил мне мой дедушка.

Raamat lebab laual, selle kinkis mulle minu vanaisa.

Vene keeles ei teki mitte mingisugust kahtlust selles osas, et vanaisa kinkis kõnelejale raamatu ja mitte laua, sest sõnad on eri soost ning lause teises pooles on kasutatud naissoost asesõna, mis saab viidata vaid naissoost nimisõnale ehk siis raamatule. Eestikeelses tõlkes ei ole asi aga sugugi nii selge ja üheselt mõistetav, sest asesõna see ei sisalda endas mitte mingisugust viidet sellele, millist sõna asendatakse. Me võime vaid oletada, et vanaisa kingituseks oli raamat. Sellised kontekstid nõuavad tôlkijalt tähelepanelikkust ning sageli 
ei olegi eesti keeles muud lahendust kui eseme või nähtuse nimetuse üle kordamine, parim viis on seda muidugi teha sünonüümse sõnaga, kui selline võimalus eksisteerib.

Keerulisem olukord võib tekkida aga siis, kui juba originaalis pole aru saada, millist nimisõna konkreetne asesõna asendab. Näide (15) pärineb ühest ehitusalasest reklaamitekstist Internetis.

(15) Мы произведём качественный ремонт в доме, стоимость которого вас обрадует.

Me teostame kvaliteetse remondi korteris, mille maksumus rõõmustab teid.

Jääb arusaamatuks, mis täpselt klienti rõõmustama peaks, kas remondi või korteri hind, seda enam, et kõnealune firma pakub nii ehitus- kui ka remonditöid.

\section{Isikuid ja ameteid tähistavad nimisõnad}

Viimane grupp sõnu, mis põhjustavad tõlkes raskusi, on isikuid ja ameteid tähistavad nimisõnad. Õigluse huvides tuleb tunnistada, et ka eesti keeles on siiski mõned võimalused isikute soo väljendamiseks. Tõsi, Kerli Puna märgib oma magistritöös: "Eesti keeles tähendab laulja seda inimest, kes laulab, olenemata tema soost. Hiljem on teistest keeltest laenatud tuletusliidete (tar-liidesoome keelestja nna-liide saksa keelest) abil tekkinud küll võimalus laulja naissoolisust rõhutada ja öelda lauljatar, lauljanna, aga see ei tähenda, et laulja märgiks nüüd ainult meessoost lauljat" (Puna 2006: 11).

Üldiselt võib eesti keeles eristada kolme võimalust soospetsiifiliste sõnade loomiseks, vaatleme neid variante lähemalt.

1. Tuletusliidete -nna, -ss ja -tar abil on võimalik moodustada sõnu, mis tähendavad elukutseid, positsiooni, rahvust jms, näiteks: laulja - lauljanna - lauljatar, õpetaja - ópetajanna, krahv - krahvinna - krahvitar, jumal - jumalanna, parun - paruness, poolakas - poolatar jne. 
Siinkohal tuleb tõlkijal pöörata tähelepanu sellele, kas naissoost isikut väljendav sõna on neutraalne. Selles, et spetsiaalse liitega moodustatud sõna, mis märgib naissugu, on igal juhul markeeritud, on keeleteadlased juba ammu kokkuleppele jõudnud, küsimus on pigem selles, kas konkreetset sõna saab kasutada igal pool ja igas olukorras. Üldiselt näib, et rahvust märkivad sõnad on neutraalsed, keerulisem lugu on aga ameteid tähistavate lekseemidega. Näiteks tundub artikli autorile, et sõna õpetajanna on tänapäevaks juba pisut arhailise kõlaga ja tõenäoliselt me ei kasutaks seda igas kontekstis täiesti neutraalsena.

Analüüsitud materjalis esines ka juhtumeid, kus tõlkes kasutakse harvaesinevaid ja siinkirjutaja hinnangul isegi pisut kunstlikult kõlavaid vorme nagu näiteks (16).

(16) Я решил этосразу, как только она явилась в подотдел и заявила, что она ученица самого N. (Её немедленно назначили заведующей Изо.). (M. Bulgakov)

Ma järeldasin seda kohe, nii kui ta allosakonda ilmus ja teatas, et on N. enda ópilane. (Ta määrati jalamaid Kunsto juhatajannaks.).

2. Eesliite nais- abil: üliópilane - naisüliópilane, sportlane - naissportlane jne.

3. Liitsõnadega: baarmen - baaridaam, toapoiss - toatüdruk, esimees - esinaine, kasuvend-kasuõde jne.

Aga on selge, et sellist soolist eristamist võimaldab suhteliselt väike hulk sõnu. Tõlkija töös tuleb paraku ette palju keerukamaid olukordi, kus parimat ja täpsemat vastet leida on väga raske ning mõnikord lausa võimatu.

Siiani oleme keskendunud sõnadele, millel on mõlemas keeles põhimõtteliselt sugu tähistavad vasted olemas ja mis tõlkimisel raskusi ei põhjusta, v.a juhul, kui ühes keeles on sõna neutraalne, aga teises keeles selgelt markeeritud või isegi negatiivse konnotatsiooniga (halvustava tähendusega sõnade kohta vt allpool). Edasi vaatleme aga juhtumeid, kus tõlkija ei saa ka kõige parema taht- 
mise juures anda sajaprotsendiliselt edasi originaali sisu. Analüüsime kahte B. Akunini venekeelse romaani pealkirja ja nende tõlkeid eesti keelde:

(17) Любовница смерти

Surmaarmuke

Любовник смерти

Surmakallike

Eesti keeles puudub sõnal armuke soolistatus, seda mõistet võib võrdselt kasutada nii mehe kui naise kohta. Näited (19) ja (20) viitavad sellele, et pigem seostub sõna armuke ikkagi naissoost isikuga. Vene keeles aga tähistatakse eri soost armukesi eri sõnadega (любовник - mees ја любовница - naine). Vastavalt Suиrele vene keele seletussõnaraamatule on sõnal любовник kolm tähendust: 1) mees, kellel on abiväline suhe; 2 ) vananenud tähendus: kallim, armunu; 3) teatris armunud noormehe roll, ja sõnal любовницаesimene ja teine tähendus (VKSS 1998). Tõlkijal pole näites (17) kuigi hästi õnnestunud sõna tähendust edasi anda, sest kallike on mõningates sõnaraamatutes märgitud küll kui vananenud sõna armukese kohta, aga on selge, et tänapäeva lugejale vaevalt et enam see tähendus esimesena pähe torkab. Pealegi on sõnal armuke üldiselt halvustav maik, mis sõnal kallike täiesti puudub.

Vaatleme korraks, kuidas on neid pealkirju tõlgitud keeltesse, kus grammatilise soo kategooria eksisteerib (vähemalt asesõnade tasemel):

a) inglise keel: She Lover of Death ja He Lover of Death;

b) saksa keel: Der Magier von Moskau ja Die Liebhaber des Todes;

c) hispaania keel: La amante de la muerte ja El amante de la muerte.

Nagu näha, on saksa keele tõlkija hoolimata oma keele võimalustest otsustanud tõlkida pealkirju hoopis teistmoodi ja loobuda otsesest soolisest vastandamisest. Inglise keele puhul võiks kerkida küsimus, miks ei ole tõlkija kasutanud näiteks sõna mistress, mille üks tähendustest on samuti 'armuke'. Tõenäoliselt on põhjuseks 
see, et tõlkija soovis säilitada teatud paralleeli kahe pealkirja vahel, seetõttu lahendas ta olukorra soole viitavate asesõnadega.

Veel mõnda aega tagasi oli käesoleva artikli autor veendunud, et sõna meesarmuke ei ole eesti keele seisukohast aktsepteeritav, aga selgus, et tegelikult võib seda lekseemi kirjasõnas leida küll, vt näide (18), mis pärineb Eesti Ekspressi kultuurilehest Areen.

(18) Rooma lähedalt leiti keiser Hadrianuse meesarmukese mälestuseks püstitatud templi varemed. (Areen)

Lisaks kõnealusele näitele võib sõna meesarmuke leida ka internetiavarustest. Siinkirjutajale tundub selline vorm siiski liialt kunstlikuna ja ilukirjandusse mitte eriti hästi sobivana ning seetõttu tuleksid võimalike tõlkevariantidena kõne alla hoopis: Surma mõrsja ja Surma peig. Kuigi ka nendel sõnadel puudub armukese negatiivnetähendus, siis saaks sel viisil anda edasi vähemalt soolist erinevust ja kui lähtuda teoste sisust, siis tuleb tõdeda, et käesoleval juhul on oluline tegelaste sooline eristamine juba raamatu pealkirjas.

Analüüsides veel kontekste, kus esinevad koos mõlemad venekeelsed sõnad (любовник ја любовница), võib jõuda küllaltki huvitava tulemuseni. Kuigi sellelaadseid näiteid ei ole palju, ilmneb põnev ja mõnevõrra üllatav tõsiasi. Näited (19) ja (20) võimaldavad jõuda esialgse järelduseni, et sõnaga armuke tõlgitakse pigem naisterahvale viitavat sõna любовниия, samal ajal kui lekseemile любовник leitakse eesti keeles kas neutraalne vaste (mees, munk) või siis koguni positiivse konnotatsiooniga sõna (armsam). Lisaks tõestab seda väidet ka see asjaolu, et kui eelpoolmainitud Rooma keisri armuke oleks olnud naissoost, ei oleks tõenäoliselt peetud vajalikuks seda rõhutada ja kasutada sõna naisarmuke. Seetõttu võib teha järelduse, et naissoost armuke on norm, meessoost aga normist kõrvalekalle ning seetõttu tuleb seda ka eraldi markeerida. Põhjalikumat arutlust normi ja markeerituse/mittemarkeerituse kohta vt Kerli Puna magistritööst (Puna 2006: 9-10). Loomulikult ei saa nende mõningate näidete põhjal teha lõplikke järeldusi, kuid uurimismaterjali edasiseks analüüsiks võib sellest tähelepanekust leida. 
(19) Вы правы, она меня не любит; но никогда не ручайтесь вделах, бывших между мужем и женой или любовником и любовницей. (F. Dostojevski)

Teil on õigus, ta ei armasta mind; kuid kunagi ärge vastutage asjade eest, mis on olnud mehe ja naise või mehe ja armukese vahel.

(20) Любовнику нельзя было отлучаться часто из монастыря своего; любовнице нельзя было посещать кельи своего любовника. (A. Radišš̌ev)

Mungal polnud võimalik sageli oma kloostrist lahkuda; tema armukesel polnud võimalik armsamat kambris külastada.

\section{Negatiivse tähendusega sõnad ja nende tõlkimine}

Lisaks eelpool mainitud olukordadele osutuvad tõlkija jaoks problemaatilisteks sellised olukorrad, kus ka vene keeles pole naissugu märkiv nimisõna täiesti neutraalse tähendusega, näiteks: секретарь - секретарша 'sekretär', врач - врачиха 'naissoost arst'halvustavalt, певеи - певица 'lauljanna' - певичка 'lauljanna'halvustavalt) jms. Halvustav konnotatsioon võib tähendada nii otsest negatiivset suhtumist isikusse, aga ka irooniat, liigset familiaarsust jms. Eri tõlkijad lahendavad need olukorrad omal moel. Üks variant on sõna tähendusvarjundit ignoreerida ja tõlkida see neutraalse vastega, vt näide (21). Teine võimalus on katsuda siiski kuidagi originaalis sisalduvat nüanssi edasi anda, näited (22), (23) ja (24).

(21) Врачиха, как выяснилось, еще не прибыла, и задержанным велели подождать в предбаннике, увешанном душераздирающими плакатами. (J. Lukin)

Nagu selgus, polnud arst veel tulnud ja kinnipeetud said korralduse oodata sauna eesruumis, mille seinad olid täis südantlõhestavaid plakateid. 
(22) Однако врачиха была с характером, живоприбрала Иосифа к рукам и заставила обучиться зубопротезному делу. (А. Rõbakov)

Aga hambatohter oli karakteriga naine, tõmbas Jossifi kärmesti liistule ja sundis proteesiasjandust ära õppima.

(23) - Ты к Потапову поедешь, Володечка? - придушенным голосом спросиламолодая врачиха, которую в отделении называли исключительно Верунчик. (T. Ustinova)

“Kas sa sõidad Potapovi juurde, Volodja?" küsis lämbunud häälel nooruke arst, keda eranditult kõik kutsusid Veruntšikuks.

(24) Может, Лора и устает, бегая по сцене и разевая рот под фонограмму, но с тех пор, как певичка поселилась у нас, остальным хоть вон беги. (D. Dontsova)

Võib-olla väsib Lora tõepoolest laval ringi joostes ja fonogrammi saatel suud ammuli ajades, kuid sellest ajast, kui lauljannake meile elama asus, on kõik ülejäänud valmis kodunt põgenema.

Näites (24) on sõna lauljannake eriti õnnestunud tõlkevaste, sest "nii vene kui eesti keeles väljendavad deminutiivsed sufiksid kõige sagedamini hellitavat tähendust, kuid võivad tekitada ka põlguse konnotatsiooni (барынька - prouakene)" (Külmoja 2003: 29).

\section{Grammatiline sugu saksa-vene tõlkes}

Kuigi käesoleva artikli esmane eesmärk on juhtida tähelepanu raskustele, mis tekivad vene-eesti tõlkes, siis selleks, et mitte kõlada liiga pessimistlikult, tuleks märkida veel seda, et on ka teistsuguseid olukordi. Ei ole väga keeruline leida kontekste, kus hätta jääb näiteks vene keelde tõlkija ja eesti keelega probleeme ei ole. See võib juhtuda siis, kui mõlemasse keelde (s.t eesti ja vene k) tõlgitakse kolmandast keelest, kus on samuti grammatiline sugu olemas.

Vene tõlkepraktikast on teada vähemalt üks väga huvitav juhtum, kus sõnade sooline eristamine osutus nii oluliseks, et mõned 
tõlkijad olid sunnitud originaali täpsest järgimisest täiesti loobuma. Mitmed vene poeedid, teiste hulgas Fjodor Tjuttšev ja Afanassi Fet, tõlkisid kuulsa saksa poeedi Heinrich Heine luuletust "Ein Fichtenbaum steht einsam", kus räägitakse männi ja palmi vahelisest armastusest ning igatsusest teineteise järele. Vene keelde tõlkimisel tekkisid aga mõistetavad raskused, sest saksa keeles on mänd mees- ja palm naissoost sõna, aga vene keeles on mõlemate puude nimetused naissoost (сосна, пальма). Selleks, et luuletuse mõte ei muutuks ja ei tekiks vihjet homoseksuaalsele armastusele, olid tõlkijad sunnitud venekeelses variandis valima hoopis teised puud (tuleb pidada silmas ka seda, et 19. sajandil, mil nad seda luuletust tõlkisid, oli homoseksuaalsuse teema üldiselt tabu). Tjuttševi tõlkes armastab palmi seetõttu seeder (кедp) ja Feti tõlkes tamm $(\partial y \sigma)$. Need suurepärased ja hinnatud vene luuletajate tõlked näitavad, et grammatilise soo väljendamine võib osutuda tähtsamaks kui täpsete sõnaliste vastete leidmine.

Lisaks Tjuttševile ja Fetile on seda luuletust vene keelde tõlkinud veel I. Pavlov, kelle tõlkes on mänd asendatud seedriga, P. Veinberg, kelle tekstis armastab palmi tamm, ning mitmed teised luuletajad. Ainus kuulsatest vene luuletajatest, kes ei lasknud ennast sooküsimusest häirida, oli poeet Mihhail Lermontov, kes jättis luuletusse oma venekeelses variandis alles nii männi kui palmi. Tuntud keeleteadlane Lev Štšerba kirjutas, et Lermontovi palm muudab kardinaalselt luuletuse mõtet, sest kaob ära mehe armastus kauge ja kättesaamatu naise vastu, tugev ning mehine armastus muutub tõlkes kaunihingeliseks unistuseks (Štšerba 1957: 98-99). Ta näeb Heine luuletuses eelkõige võimatut armastust, mis Lermontovi tõlkes transformeerub lihtsalt üksinduse teemaks (Štšerba 1957: 104).

Ei ole vaja rõhutada, et eesti keelde tõlkimisel ei põhjusta saksakeelsete sõnade sugu mitte mingisuguseid takistusi. Eesti keele seisukohast võib palmi järele igatseda mänd või ükskõik milline teine puu.

Siinkohal tasub teha väikene kõrvalpõige ja mainida, et ka suulises tõlkes on eesti keele tõlgi olukord veidi lihtsam oma vene töökeelega kolleegi omast. Olukorras, kus tõlgitakse vene keelest eesti keelde, saab tõlk alati kasutada asesõna tema vastena vene- 
keelsetele lekseemidele $о н$ ја она. Kui aga tõlge toimub eesti-vene suunal ja kõnes kasutatakse vaid asesõna tema, on tõlkija tunduvalt tõsisema probleemi ees, sest vene keel nõuab asesõnade soolist eristamist. Suulise tõlke praktikas on tulnud ette olukordi, kus tõlk on otsustanud ühe või teise asesõna kasuks (sagedamini valitakse meessoost asesõna) ja siis on kõne keskel, mõnikord ka päris lõpus selgunud, et juttu on olnud hoopis teisest soost isikust. Sellises olukorras tuleks tõlgil jääda võimalikult umbmääraseks, ehk siis eelistada võimalusel sõnu, mis ei sisalda endas vihjet inimese soole, näiteks lekseemе человек, персона, личность jne.

\section{Lõpetuseks}

Lähtuvalt toodud näidetest võib eeldada, et grammatilise soo kategooria tekitab raskusi eelkõige tõlkeprotsessis, siis tegelikult põhjustab see kategooria mõningast segadust ka keelesiseselt. Üksikasjadesse laskumata võib tuua ühe näite, et seda väidet kinnitada.

Vene keeles on üks lekseem, mille sooline kuuluvus on juba pikka aega tekitanud diskussioone, selleks sõnaks on кoøe 'kohv'. Oma vormilt sarnaneb see sõna tüüpilise kesksoost sõnaga nagu näiteks поле 'põld', солнце päike'. Aga kuna tegu pole algupäraselt venekeelse sõnaga, vaid see on vene keelde tulnud prantsuse keelest, kus sõna le café on meessoost, siis oligi laenu esialgne kuju

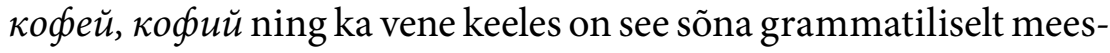
soost. Paraku aga kipuvad nii keeleõppijad kui ka tegelikult emakeele kõnelejad ise selle sõna ühildamisel sageli vigu tegema. Vene keeleteadlane Jelena Remtšukova kirjutab sõna кoøe kohta koguni, et "mittenormikohane kesksugu tõrjub tasapisi välja normatiivse meessoo, sest sõna struktuur sisaldab täishäälikut $o$, misassotsieerub kesksoo lõpuga, samuti tähistab sõna elutut objekti ja need seigad osutuvad tunduvalt tugevamateks mõjufaktoriteks kui meenutus sõna algse soolise kuuluvuse kohta" (Remtšukova 2005: 125). Seepärast on tehtud isegi ettepanekuid lasta selle sõna grammatiline sugu n-ö "vabaks", s.t et omadussõna, mida kõnealuse nimisõnaga koos kasutatakse, võiks olla nii meessoost kui ka kesksoost. 
Keegi keeleteadlane pani ette, et sõna kohv võiks vene keeles olla meessoost, kui tegu on kange ja hea kohviga, ning kesksoost, kui räägime halvast, lahjast ja piimaga kohvist (Remtšukova 2005: 125-126).

Mis puudutab vene-eesti tõlget, siis on jätkuvalt keeruline otsustada, kas grammatiline sugu on tõlkija sõber või vaenlane. Selge on aga see, et kõnealune grammatiline kategooria pakub palju huvitavaid väljakutseid. Tõlkijad võivad end lohutada sellega, et on siiski teatud hulk kontekste, kus grammatilise soo puudumine eesti keeles osutub tõlkeprotsessi lihtsustavaks asjaoluks. Tõenäoline on, et seoses soolise võrdõiguslikkuse teemaga tuleb soolist eristamist ka keelde aina rohkem juurde (kas või uute sõnade kujul) ning võimalik, et ühel päeval on praegused grammatilisest soost tingitud tõlkeraskused muutunud minevikuks.

\section{Allikad $^{25}$}

Akunin, Boris 2005. Surma armuke. Tallinn: Tänapäev.

Akunin, Boris 2005. Surma kallike. Tallinn: Tänapäev.

Astafjev, Viktor 1981. Karjapoissi-karjapiigat: tänapäeva pastoraal. Tallinn: Perioodika.

Bulgakov, Mihhail 1995. Meister ja Margarita. Tallinn: Varrak.

Bulgakov, Mihhail 2004. Saatanlik lugu. Saatuslikud munad. Koera süda. Tallinn: Täna päev.

Dontsova, Darja 2007. Kõõrdsilmsusemikstuur. Tallinn: Ersen.

Dostojevski, Fjodor 1987. Kuritöö ja karistus. Tallinn: Eesti Raamat.

Eesti kultuurisündmuste kalender http://www.kultuur.info/syndmus/ogarditeoo-kokk-varas-tema naine-ja temakese-armuke-15576/ (vaadatud 26.01.2012)

Fedin, Konstantin 1952. Ebatavaline suvi. Tallinn: Eesti Riiklik Kirjastus.

25 Mitmed näited on leitud vene keele rahvuskorpuse (http://www.ruscorpora.ru/) abiga. 
Heine, Heinrich 1985. Gedichte. Berlin: Aufbau-Verlag.

Iskander, Fazil 1978. Õnnelike leidude aeg. Tallinn: Eesti Raamat.

Leiti Rooma homotempel. - Areen 27.11.03, lk B6.

Radištšev, Aleksandr 1958. Reis Peterburist Moskvasse. Tallinn: Eesti Riiklik Kirjastus.

Rõbakov, Anatoli 1983. Raske liiv. Tallinn: Eesti Raamat.

Tšehhov, Anton 2005. Jutustused. Tallinn: Tänapäev.

Ulitskaja, Ljudmilla 2009. Medeia ja tema lapsed. Tallinn: Tänapäev.

Ustinova, Tatjana 2002. Suur kurjus ja väiksemad nurjatused. Tallinn: Ersen.

Ustinova, Tatjana 2006. Eriotstarbega sõbratar. Tallinn: Ersen.

Акунин, Борис. 2001. Любовник смерти. Москва: Захаров.

Акунин, Борис 2001. Любовнииа смерти. Москва: Захаров.

Астафьев, Виктор Петрович 1996. Так хочется жить: повести и рассказы. Москва.

Булгаков, Михаил 1980. Мастер и Маргарита. Рассказы. Москва.

Донцова, Дарья 2004. Микстура от косоглазия. Москва.

Достоевский, Федор Михайлович 1969. Преступление и наказание. Калининград.

Искандер, Фазиль Абдулович 1973. Время счастливых находок: повести и рассказы. Москва.

Лермонтов, Михаил Юрьевич 1988. Сочинения в 2-х томах. Т. 1. Москва. Радищев, Александр Николаевич 1970. Путешествие из Петербурга в Москву. Москва.

Рыбаков, Анатолий Наумович 1982. Тяжелый песок. Москва.

Тютчев, Фёдор Иванович 1966. Лирика. В 2-х томах. Т.2. Издание подготовил К. В. Пигарев. Москва.

Улицкая, Людмила Евгеньевна 1996. Медея и ее дети: повести. Москва.

Устинова, Татьяна Витальевна 2002. Подруга особого назначения. Москва. 
Устинова, Татьяна Витальевна 2006. Большое зло и мелкие пакости. Москва.

Федин,Константин Александрович 1950.Необыкновенное лето. Москва.

Фет, Афанасий Афанасьевич 1901. Полное собрание стихотворений А. А. Фета / под ред. Б.В.Никольского. С.-Петербург.

Чехов, Антон Павлович 1970. Собрание сочинений в восьми томах. Том 3. Москва.

\section{Kirjandus}

Aksjonov 1984 = Аксёнов, Анатолий Тихонович. К проблеме экстралингвистической мотивации грамматической категории рода. - Bonpocbl языкознания № 1. Москва 1984: Наука, с. 14-25.

Deutscher, Guy 2010. Does Your Language Shape How You Think? - The New York Times 26.08.2010. Internetis http://www.nytimes.com/2010/08/29/magazine/29language-t.html?scp=1\&sq=Does\%20Your\%20Language\%20Shape $\% 20$ How\%20You\%20Think?\%20\&st=cse (vaadatud 26.01.2012).

EKSS $2009=$ Eesti keele seletav sõnaraamat . Toim. Margit Langemets, Mai Tiits, Tiia Valdre, Leidi Veskis, Ülle Viks, Piret Voll. Tallinn: Eesti Keele Sihtasutus.

Külmoja 2003 = Кюльмоя Ирина, Вайгла Эда, Соль Майе. Краткий справочник по контрастивной грамматике эстонского и русского языков. Тарту: Tartu Ülikooli Kirjastus.

Lange, Anne 2008. Tõlkimise aabits. Tallinn: Valgus.

Makko, Maris 2011. Mis inimesed? Mehed ja naised! - Eesti Päevaleht 26.05.2011 (vaadatud 26.01.2012).

Nikunlassi Ahti 2000. On gender assignment in Russian. - Gender in Grammar and Cognition, I Approaches to Gender. II Manifestations of Gender. Eds. Barbra Unterbeck (Part I), Matti Rissanen, Terttu Nevalainen, Mirja Saari (Part II). Berlin, New York: Mouton de Gruyter.

Puna, Kerli 2006. Soospetsiifilised isikunimetused sõnaraamatutes ja tekstides. Magistritöö. Tartu Ülikool: Eesti keele õppetool. 
Remtšukova 2005 = Ремчукова, Елена Николаевна. Креативный потенциал русской грамматики. Мосвка: Либроком.

Šeljakin 2001 = Шелякин, Михаил Алексеевич. Функииональная грамматика русского языка. Москва: Русский язык.

Šeljakin 2002 = Шелякин, Михаил Алексеевич. Русский язык. Справочник. Таллинн: Koolibri.

Štšerba 1957 = Щерба, Лев Владимирович. Опыт лингвистического толкования стихотворений. II. «Сосна» Лермонтова в сравнении с её немецким прототипом. - Избранные работы по русскому языку. Москва.

Zaliznjak 1967 = Зализняк, Андрей Анатольевич. Русское именное словоизменение. Москва: Наука.

Vastšenko 1984 = Васченко, Виктор. Грамматическая категория общего рода в русском языке. - Вопросы языкознания № 5. Москва: Наука, с. 60-68.

VKSS 1998 = Кузнецов, Сергей Александрович. Большой толковый словарь русского языка. Российская академия наук, Институт лингвистических исследований. Санкт-Петербург: Норинт.

\section{Summary}

\section{Grammatical gender - translator's friend or enemy?}

Significant differences between languages are always challenges for a translator. The current article analyses difficulties caused by the existence of grammatical gender in Russian and the absence of that category in Estonian. The most difficult contexts for a translator can be divided into three groups:

1) Russian pronouns он (he) and она (she) vs Estonian tema (he or she).

2) Russian pronouns он and она when they refer to objects vs Estonian see (it). 
3) Different nouns that mark professions, nationality, etc.

Estonian language has some means to compensate the absence of the category of grammatical gender:

1) Suffixes: -nna (kuninganna - queen), -tar (lauljatar - female singer).

2) The prefix nais- (naispoliitik - female politician).

3) Compound words, in which one part of the word refers to the sex of the person (kasuode - stepsister and kasuvend - stepbrother).

In Russian each noun is assigned a gender. Russian has three genders: masculine, feminine, and neuter (neutral). In the cases of words like 'father' these relate to physical gender. In the case of other objects like 'pen', 'house', there is no physical meaning attached to the grammatical gender.

A group of words also exists that can refer to either male or female, for example: ребенок 'child', подросток 'teenager', враг 'enemy', персона 'person', etc.

In case of Russian pronouns $\mathrm{OH}$ and она Estonian translator has several options:

1) Replacing Russian pronouns in translation with nouns, such as: man, woman, girl, boy etc. However, it is possible only in the sentences where the person's age is known.

2) Using the pronoun tema in Estonian text, it is important to keep in mind that it can be done only when the reader will not get confused.

3) Referring to the concrete character with his or her name. The translator has to be careful in understanding completely the author's intentions. For example, if the author of the original text wanted to be mysterious and not to reveal the character's name, the translator has no right to do that either.

Comparing Russian pronouns $\mathrm{OH}$ and $о \mathrm{Ha}$ when they refer to objects and Estonian see, it can be said that in Estonian when it is important to distinguish between different objects, in most cases the translator has to repeat the name of the object, since the Estonian pronoun see does not include the meaning of grammatical gender. 
The third group of difficult words for a translator is that denoting professions, nationality, etc. In general, words expressing feminine gender are marked. Nevertheless it seems that lexemes that stand for nationality (эстонка - eestlanna - female Estonian) or status (королева - kuninganna-queen) are more "neutral" than different business titles such as ópetajanna (female teacher). Russian words врачиха, певичка are especially difficult to translate, since in addition to the fact that they refer to female, they also have a negative connotation.

Key words: grammatical gender, Estonian, Russian, translation, pronouns, nouns. 


\section{Tänapäeva vadja keel - kõnes ja kirjas}

\section{Heinike Heinsoo}

doi:10.7592/PS/28-5heinsoo

Teesid: Artiklis vaadeldakse tänapäeva viimaste vadja keele kõnelejate keelt. Vadja keele kõnelejaid on vaid viis, aga viimase paarikümne aasta jooksul on vadja aktivistide tegevuse tulemusel hakatud looma kirjakeelt, mis nüüd on märkimisviisilt stabiliseerumas. Probleeme on Vaipoole kahe küla murdeerinevuste osas seisukoha võtmisega. 2003. aastast alates on kirjakeelega katsetatud ja avaldatud peamiselt muinasjututekste, mida on osaliselt "tõlgitud" Vaipoole murdesse. Vadjakeelseteks originaalteosteks võiks pidada 2010. aastal ilmunud kahte raamatut: "Vad'd'a päivüszikko 2011" ("Vadja kalender 2011) ja "Vad'd'a krazgõttavõ cirja" ("Vadja värvimisraamat"). Vadjalastele ja vadja külaelanikele mõeldud keelekursuste käigus selgus 2010. ja 2011. aastal, et praktikas läheb kirillitsas koolihariduse saanud eakatel õppijatel ladina tähestikul põhineva kirjaviisi omaksvõtmisega aega.

Märksõnad: Hääbuv keel, identiteet, kirjakeel ja murded, kirjakeele kujunemine, tõlkimine ja originaallooming.

\section{Vadja keel on hääbuv keel}

Traditsiooniliselt eristatakse vadja keeles nelja murret: idavadja, läänevadja, kukkusi ja kreevini murre. Läänevadja murret on jagatud omakorda kolme rühma: orko, mätši, ja Vaipoole. Tänapäeva viimased vadja keele kõnelejad elavad Vaipooles ja Vaipoolest lähtub ka vadja aktivistide tegevus. Vaipooles on kolm küla: 
Jõgõperä ja praegu administratiivselt üheks Luuditsa külaks liidetud Liivtšülä ja Luuditsa. Jõgõperä ja Liivtšülä-Luuditsa keel on erinev. Vaipooles on kuus vadja keele kõnelejat.

Zina Saveljeva (1938) on sündinud ja kasvanud Liivtšüläs, aga elab juba aastaid Jõgõperäl. Vaatamata sellele, et suurema osa oma elust on ta veetnud Jõgõperäl, kõneleb ta Liivtšülä-Luuditsa dialekti, sest tema lapsepõlv möödus Liivtšüläs. Zina on võimeline vadja teksti ladina tähtedega kirja panema. Emakeelse kõnelejana tajub ta häälikute pikkust ja kvaliteeti ilmselt paremini kui keegi teine ning suudab usaldusväärselt märkida, kas mõnes vormis on pikk või lühike vokaal või on lõpuvokaal sõnast hoopis kadunud.

Sergei Jefimovi (1954) vanemad olid vadjalased. Sergei etniliseks äratajaks on tema venelannast abikaasa Tatjana Jefimova, esimene Hõimurahvaste programmi Ilmapuu auhinna laureaat 2010. aastal. Auhind antakse soomeugrilist tegevust harrastavale aktivistile, kelle otsene töö pole selle tegevusega seotud. Jefimova algatusel on loodud ka vadja kultuuriseltsi kodulehel olev virtuaalne muuseum (http://vatland.ru/museum), millele on materjale vadja keeles sisse lugenud ka Sergei.

Nina Lenivenko (1935) on elanud suurema osa oma elust Jõgõperäl, kahekesi 1956. aastal sündinud tütre Tanjaga. Nina elab juba kümmekond aastat tööstuskeskuses Ust-Lugas ning tema suhtumine oma identiteeti on kahtlev ja kultuuripilt üsna venelik, kuna ta juhatas aastaid klubitööd ja tegeles vene kultuuri levitamisega. Hea laulja ja akordionimängijana eelistab ta vene estraadi.

Paša Kartašova (1928) elab Liivtšüläs, mis praegu on liidetud administratiivselt Luuditsa külaga. Tema keeles on palju isuripärast ning ka vene keel tahab sekka lipsata, aga õigele lainele saades on tema keel elav ja nünasirohke.

Nikolai Nesterov (1921) on vanim vadjalane. Kuulmise ja nägemisega on tal probleeme, aga vadjakeelne jutt tuleb endisel erusõjaväelasel hästi välja. Luuditsas on ta siiani veetnud oma eluõhtu soojema aja kevadest sügiseni. Tema on heaks näiteks selle kohta, kuidas Nõukogude armee pole suutnud inimest oma rahvust unustama panna. 
Ivan Georgijev (1928) on sündinud Luuditsas ja elab seal pidevalt. Ivani keel on vaba ja ta suudab üsna ladusalt tõlkida venekeelset teksti vadja keelde. Ivani isa Kiko Georgijev pajatas palju aastaid tagasi Paul Aristele hulgaliselt meremehejutte.

\section{Keelaksutuse muutus}

Lauri Kettunen arvas 1911. aastal oma esimese Vadjamaa reisi ajal, et Jõgõperä murre on vadja, isuri ja eesti keele segu (Kettunen 1945: 204).

1925. aastal kirjutas Dmitri Tsvetkov: "Usu keel on vadjalastele enamasti täiesti võõras. 60 või 80 aastat tagasi sai ainult $10 \%$ vadjalastest aru usu keelest (kiriku-slaavi keelest), ja 50\% - vene keelest. Aga aeg muutus /---/ Usu keel on praegu arusaadav suuremale osale, vene keelt räägivad kõik, välja arvatud kõige vanem põlv, kes oskab vene keelt halvemini, moonutades seda vadjapäraseks. /---/ Viimastel aegadel sündis assimileerumine ruttu igas harus. Toon näite: vadja majasse, kus veel kõneldakse vadja keelt, tuuakse noorik-isurlane, ja mis sünnib? Kõik perekonna liikmed, isegi vanad, hakkavad kõnelema isuri keelt." (Tsvetkov 1925: 42-43).

1942. aastal oli 11.-13. septembrini Vaipooles Ilmar Talve, kes kirjutas keele kohta: "Vadja keelt kõneldakse, aga mul jäi selline mulje, et see pole enam elav keel, rohkem kasutatakse isuri ja soome keelt. Vadjalased kasutavad ka ise omavahel kõneldes keelt, millel on tugev isuri mõju. Isegi lapsed räägivad isuri keelt, ehk oskavad ka vadja keelt (Talve 1990: 63-64).

Iseloomulik oligi suund sellele, et mitmed pered läksid üle isuri keelele, nt abielu kaudu. 1980. aastast mäletan peresid, kus üks õdedest pidas ennast vadjalaseks (Dunja Rodionova) ja teine õde (Tamara Borissova) isuriks.

1950. aastatel iseloomustas Paul Ariste vaipoole keelt kui segakeelt ja ütles, et vadja külades võib kohata inimesi, kes arvavad, et nad oskavad vabalt vadja keelt, aga tegelikult kõnelevad vaid vadja ja isuri segu ja mõnedel juhtudel vadja ja soome segakeelt. Tema arvates olid sellised keelesuhted väga tavalised Jõgõperäl, Liiv- 
tšüläs ja Luuditsas. Ariste väitis, et kõnealustes külades on segakeele kõnelemine niivõrd üldine, et ka isurite keeles on palju vadjapärasusi (Ariste 1960: 203-204).

Nihe on toimunud eelmise sajandi lõpus. Vadjalased enam isuri keelele üle ei lähe. Praeguse seisuga kõneleb enamik Vaipoole vadjalasi vene keelt. Probleeme tekitab viimastele vadjalastele murrete erinevus kahes külas - Jõgõperäl ja Liivtšülä-Luuditsas. Küsimus pole selles, et üksteist ei mõisteta, vaid selles, et kirjutatud keele puhul peaks võtma seisukoha, milline murdekuju saab selle aluseks.

\section{Ühiskondlik-poliitilised sanktsioonid keele elustamiseks}

Vadjalased on Venemaa väikesearvuline põlisrahvas. 2008. aasta 13. oktoobril võeti vadjalased vastu Vene Föderatsiooni väikesearvuliste põlisrahvaste nimekirja (Единый перечень коренных малочисленных народов России). 31. novembril 2008. aastal kirjutas kohalik leht sel puhul: "Selle väikese rahvakillu, keda on ainult 73 inimest, pingutuste tulemusel on säilitatud traditsioonid ja keel, antakse välja õpikuid ja lastele toimuvad, seni küll fakultatiivsed, emakeeletunnid..." Siin kõlab läbi tugev propagandistlik noot, mis suurrahvast kiidab ja ka väiksemat tähelepanust ilma ei jäta. Õpikuid ilmunud pole ja emakeeletunde ka pole, sest vadjakeelsete vanemate lapsi koolis ei ole. Ei saagi olla, sest praegu vadja keelt kõnelevate vadjalaste lapsed on täiskasvanud ja pole oma vanemate suust iial vadja keelt kuulnud. Pealegi ei ela nad enam kodukandis. Vanuse poolest võiksid Krakolje koolis käia nende lapsed, aga need käivad heal juhul suvel vanavanemate juures külas. 


\section{Rahvaloendused ja identiteet}

Dmitri Tsvetkov kirjutas 1925. aastal: "Kahjuks ei ole meil täpseid andmeid rahva arvu kohta. Ühede arvamiste järgi pole vadjalasi enam kui tuhat inimest, kuna aga teiste arvamise järgi on neid ligi kümmetuhat hinge... Õige küll, mõned nendest kõikuvatest arvudest nagu põhjeneksid täpsete andmete najal - Vene rahvalugemiste järele. Aga kui me võtame arvesse rahva hooletu ülestähendamise viisi pimedates maanurkades, mis tehtud oli vilumata inimeste poolt (isegi umbkaudselt, trobikondade viisi) ja ka selle asjaolu, et väga raske on rahvast liigitada keele põhjal, sest sageli ei tunnud üleskirjutajad rahva keelt ja otsustasid ainult enese "arvamise" või ebaselgete andmete järele, mis olid antud kolmandate isikute poolt... Kõige õigem rahva ülesmärkimisviis oleks muidugi isiklik järele pärimine perekonna isalt tema rahvuse kohta, aga praegu on meil võimata seda vahenditult korda saata" (Tsvetkov 1925: 39-40). Sama näitas 2002. aasta rahvaloendus - vadjalaste arvuks oli selle põhjal 73 ja keeleoskajaid lausa 10 korda rohkem. Vadja külades väitsid toonased vadja keele kõnelejad, et rahvaloendaja polnud nendeni jõudnudki. Rahvuseks pandi see, mis passis - venelane. Tegelik vadjalaste arv või siis õieti vadja keele kõnelejate arv, kellel oli kontakt oma keelekeskkonnaga, oli sel ajal ehk paarikümne kandis. Enne 2010. aasta oktoobris toimunud rahvaloendust küsitles ajakirja "Русский Репортер" ajakirjanik Jana Romanova viimaseid vadjalasi selles osas, mida nad rahvaloendusel oma rahvuse kohta kavatsevad öelda (Romanova 2010). Mõned väljavõtted: Tatjana Naumova (s 1941): "Nüüd muidugi kirjutan ennast vadjalasena üles, juttugi ei saa olla millestki muust”; Zina Saveljeva: "Muidugi vadjalane, aitab juba kartmisest"; Aleksander Borissov (1932-2012): "Mulle on see tegelikult ükskõik"; Taissa Mihhailova (1934), Nina Lenivenko, Nikolai Nesterov: "Venelane, nagu passis on." Siia sobib taas Tsvetkovi kommentaar: "Ja kui rahvaste määramise põhimõte ütleb, et rahvust ei või valida oma soovi järele, et teda ei või omandada äraõppimise kaudu vaid teatavasse rahvusesse kuuluvuse tunne kujuneb iseenesest, vallates inimhinge 
sügavuses sündivaid liikumisi, siis sammub see põhimõte vadjalaste juures viimasesse arengujärku, ikka vähem ja vähem valu sünnitades" (Tsvetkov 1925: 42).

\section{Kool ja vadja keel}

Jõgõperä koolide ajalugu pole täpsemalt uuritud, aga 20. sajandi alguses oli olemas igatahes külakool, veidi hiljem ka kihelkonnakool (Ernits 2009: 31).

Vadjalased on saanud kooliharidust mõningate väikeste eranditega ainult vene keeles (aastail 1936.-1937. õpetati Luuditsa koolis vadja lapsi isuri keeles). Dmitri Tsvetkov kirjutas 1925. aastal: "Täielikult hukka mõistes endise Vene keisririigi pärismaade poliitikat, pean ometi konstateerima, et vene koolide asutamine vadjalaste keskel ei tekitanud viimastes mingisugust vaenutunnet. Vadja rahvas pigemini tervitas neid sammusid, tundes oma isoleeritud olekus, et koolide kaudu võib sügavamini kreeka-katoliku usu müstikat tundma õppida ja selgemini aru saada omast suurest naabrist, kelle vaimline sugulus on ajaloo toode. Kool tungis samm-sammult rahva sekka. Aeg õigustas tema ebaloomulikkuse ja lõppude lõpuks sai nende meelsuse kohaks." (Tsvetkov 1925: 42-42). Krakolje keskkool (Jõgõperä kool) on pärast perestroikat olnud üsna aktiivselt tegev kohaliku põlisrahva keele ja kultuuri esiletoomisega. Lasteansambel on aastaid muutuvas koosseisus laulnud vadja laule, Jõgõperä kooli juures õpetas 1990. aastate keskel vadja keelt lingvist Mehmet Muslimov, kes kaitses kandidaadiväitekirja Lääne-Ingeri keelekontaktide alal. Muslimovil on Internetis ka viis vadja keele tundi (http://www.vatland.ru).

Muslimovit abistasid koolilastega tegelemisel vadjalased Zina Saveljeva ja Tatjana Prokopenko (1935-2006). Vahel lõi kaasa ka vadja aktivist Tatjana Jefimova. Igatahes on nende tundide tulemusel vadja lasteansamblil "Linnut" ("Pääskölinnut") olnud kergem ära õppida vadjakeelseid laule ja väikeseid sketše. Käesoleval aastatuhandel on õpetus olnud juhuslik. 


\section{Emakeelsed õpetlased ja kirjakeel}

1932-1937 eksisteeris ladina tähestikul põhinev isuri kirjakeel, mida õpetati ka koolides. Isuri kirjakeele lõi Väino J. Junus, kes oli ilmselt soomlane. Junus sündis 1905. aastal Pokisenpurskaja külas ja lasti maha 15.11.(1.11?)1937. aastal. Junus töötas Leningradi Ajaloo ja Lingvistika Instituudis dotsendina ja valmistas ette isurikeelset õppematerjali (Mirenkov 2002: 208). Õppematerjal oli mõeldud nii Soikkola kui ka Alam-Lauga murde kõnelejatele. 1932. aastast 1937. aastani valmis 32 õpikut. Mõnede järgi õppisid ka Luuditsa algkooli õpilased.

Ainus vadja haritlane Dmitri Tsvetkov sündis 30.08 .1890 Jõgõperäs ja suri 26.08.1930 Narvas. Tsvetkovi kohta on põhjaliku ja huvitava raamatu kirjutanud Enn Ernits (2009). Tartus professoriametit pidava Lauri Kettuneni kutsel tuli Tsvetkov Tartu Ülikooli õppima. Emakeele Seltsi stipendiaadina valmis tal vadja-eesti sõnaraamatu käsikiri (Tsvetkov 1995), grammatika oli tal juba varem valmis (Tsvetkov 2008). Tsvetkovist ei saanud votoloogi, vaid slavist ja kooliõpetaja Alajõe koolis, ta kaotas huvi vadjalaste ja vadja keele arendamise vastu. Tema grammatikat pole tänapäeval õpetuses võimalik kasutada; sõnaraamat on väärtuslik sõnavarakogu.

\section{Kas vadja keelel on kirjakeelt?}

\section{Murded}

Kolme Vaipoole küla keel erineb omavahel ennekõike lõpuvokaalide poolest (Markus, Rožanskyi 2011: 45). Trükis ilmunud grammatikad tuginevad läänevadja Kattila (mätši) küla keelele. Markuse ja Rožanskiy 2011 aastal ilmunud “Современный водсий язык” on põhjalik ülevaade tänapäeva vadja keelest, s.o Jõgõperä ja Liivtšülä-Luuditsa dialektist. 


\section{Uurijate kirjapanekud}

Esimesed vadja keele kirjapanekud on pärit 1783. aastast. 19. sajandi vältel panid vadja keelt kirja asjaarmastajad, folkloristid, lingvistid. Kirjapanekute tase ja huvid muutusid läbi aegade (Heinsoo 2004, Heinsoo, Kuusk 2011). 1909. aastal kasutas E. N. Setälä (Posti, Suhonen 1964) vadja keele ülesmärkimiseks soome-ugri teaduslikku transkriptsiooni (FUT). Sellest ajast alates on seda vadja keele ülesmärkimiseks suurema või väiksema foneetilise täpsusega kasutanud enamik lingviste. Niisiis on üleskirjutatud teksti palju, aga tavalugejale, eriti kirillitsas lugema ja kirjutama õppinud vadjalastele on nende lugemine keeruline. Seda enam, et venekeelse tõlkega tekstid praktiliselt puuduvad.

\section{Kirjakeele sünd}

Tänapäeval kõneldakse vadja keelt ainult Vaipooles ja seetõttu peaks kirjakeel põhinema ka sellel murdel. Tõsi, murre erineb kahes külarühmas. Huvitavad on O. A. F. Mustoneni kirjapanekutd Jõgõperält (Mustonen 1883), mida võiks täielikult tänapäeva vadja kirjakeeleks lugeda. Transkriptsioonimärgid praktiliselt puuduvad, tekst on selge ja loetav, ehkki keeles on muidugi 120 aasta jooksul toimunud muutusi (Mustonen 1883: 154).

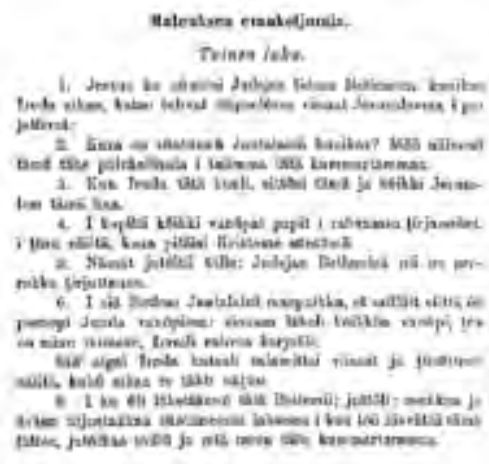

Matteuse evangeelium. 
Vadja haritlane Dmitri Tsvetkov lõi omapärase kirjaviisi kirillitsa baasil, lisades häälikute $\ddot{a}, \ddot{o}, \ddot{u}$ tähistamiseks vene tähtedele peale kaks täppi (Tsvetkov 2008). Vadja keele sõnaraamat kasutab vadja keele ülesmärkimiseks praktiliselt eesti kirjakeelt, aga kajastab vajaliku täpsusega eri murretele iseloomulikke jooni (Tsvetkov 2008: 30, 3):

Enn Ernits nimetab vadja kirjakeele loojaks Sankt-Peterburgi lingvisti Mehmet Muslimovit (Ernits (2006, 2010b), kes 2002/2003. aastal pani Internetis üles viis õppetundi (http://www.vadjamaa. narod.ru/language/language.html). Tema loodud kirjaviisis avaldati ka 2003. ja 2004. aastal esimesed raamatud. Trükis ilmusid "Vađđa kaazgõt" ("Vadja muinasjutud"). Muinasjutud põhinevad Paul Ariste ja Julius Mägiste kirjapanekutel ja erinevuseks eri aastatel ilmunud muinasjuturaamatute vahel on see, et 2003. aasta väljaandes esitatakse algupärane, uurijate kirjapandud murdekuju, aga 2004. aastal on tekstid "tõlgitud" Jõgõperä murdesse. Teiste murrete tekste on Jõgõperä murdesse pannud ka Dmitri Tsvetkov. Ta abistas Lauri Kettuneni tema üleskirjutuste ülevaatamisel ja “tõlkis" Jõgõperä murdesse 7 idavadja teksti (Kettunen, Posti 1932: 118-144). Tsvetkovi kirjapanek oli teaduslikus transkriptsioonis.

Ülesmärkimisviis on pidevalt muutunud ja sellest on kirjutanud põhjalikult Enn Ernits (2006, 2010b). Vadjakeelne esialgne alfabeet, lühitõlkeid ja temaatilisi sõnaloendeid on ilmunud ka kohalike aktivistide poolt välja antud ajalehes "Maavätši” (hakkas ilmuma 2005. aastal), mille peaeesmärk on tutvustada Vaipooles ja selle ümbruses toimuvat, vadja kultuurielu ja kodulugu.

2009. aastal ilmus Olga Konkova toimetatud "Vad'd'aa rahvaa jutud ja kaazgad" (Konkova 2009), milles muinasjuttudel on venekeelne tõlge ja tekste on üritatud panna Muslimovi loodud kirjakeelde ja ka Jõgõperä murdesse. Enn Ernits tunnustabki kasutatava kirjaviisi kirjakeeleks: "Kõik vadja rahvaluule tekstid on avaldatud kirjakeeles, kusjuures murde eripärad on säilinud" (Ernits 2010a: 858). Raamat on kaunilt illustreeritud ja meeleolukas. 


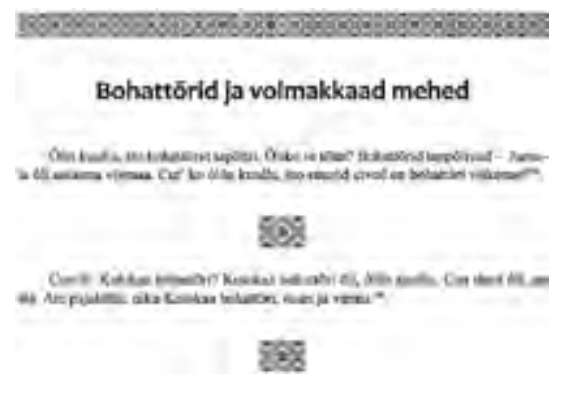

Bohattõrid. (Konkova 2009: 34)

Vadja kirjakeele üheks nõrkuseks oli kaua vadja keele kõige iseloomulikuma joone $t \check{s}(\check{c})$ märkimine $c$-grafeemiga. Probleemiks oli väidetavalt grafeemimärgi č tülikus ja $c$ kasuks esitatud argument oli suhteliselt lihtne - kel vaja, see teab nagunii, mis häälikut $c$-ga märgitakse. Soomepärane $y$-vokaalimärgi kasutamine läheb vokaalimärkimise süsteemist välja, sest kasutusel on eesti kirjakeele $\tilde{o}$-grafeem (Kuznetsova 2010, Jefimova 2010). Seitsmeköiteline "Vadja keele sõnaraamat" kasutab eesti alfabeedil põhinevat lihtsustatud märkimisviisi (1990-2011). Lahknevused kõiki murdeid kajastava hiiglasliku sõnaraamatu ja kohaliku kirjaviisi vahel segavad kindlasti sõnaraamatu kasutamist. Nüüd viimasena vadja kodulehel (http://vatland.ru./lang/index.php) avaldatud alfabeet on samasugune, nagu seda kasutab vadja keele sõnaraamat.

\section{Tõlkimine ja algupärane vadjakeelne looming}

\section{Tõlkimine}

Enamik vadja tekste on tõlgitud tekstid. O. A. F. Mustonen avaldas vadja keeles Matteuse evangeeliumi 2.-6. peatüki, mille tõlkija pole teada, aga keel on Vaipoole, täpsemalt - Jõgõperä keel. Ehkki kirjapanek, on see väga arusaadav ka tavalugejale, kes vadja keelt oskab. Ühest murdest teise "tõlkimist" on esinenud rohkem. Näi- 
teks Dmitri Tsvetkov tõlkis Kettuneni idamurde tekste Jõgõperä murdesse.

Ainsaks kirjanduslikuks tõlkeks võib pidada tema Tšehhovi novelli "Vanka" tõlget (Kettunen, Posti 1932: 144-152). See on heatasemeline, sõnavara on rikas ja lauseehituses pole originaaltekstisse klammerdutud. Kogu tõlkes kajastub tõlkija hea vene ja vadja keele oskus ning järjekindlus enda loodud lõpukaolise Jõgõperä keelenormi kasutamisel.

Tavaliselt on enamik tõlkeid, mida vadja keele oskajad teevad, muidugi suulised, mõeldud küsitlejale-lingvistile, kes teksti kirja paneb. Vahel on tekst loodud enda tarbeks. Huvitav on Tatjana Prokopenko meieisapalve tõlge, mille ta 2003. aasta külapeol ette kandis. Tõlget võib kuulata Taisto Raudalaineni ja Ergo Västriku filmist "Ja päästa meid ära kurjast” (60 min, ETV 2004).

Tõlke kohta ütleb ta Tamara Borissovale: miä izze vääntäzin 'ma ise tõlkisin':

Anna meille leipää süümä vart i prosti meild meije võlgad kui mü prostimme meije võlgad inemizille. Võta meilt pois tak iskušen' je i oo meije poolõss paganuzõs.

Tekst oli paberil kirjas ja ka ette valmistatud, aga Tatjana ei lugenud seda maha.

Tõlkimine ongi praegu kõige suurem probleem. Vadja keele sõnaraamatus on enamasti ka venekeelsed tõlked, aga nende leidmine pole kerge, sest selleks peab läbi lugema sõnaartikli eestikeelese osa. Vene-vadja sõnaraamat siiani puudub, ehkki Eesti Keele Instituudil on see kavas välja anda. Napi keeloskusega entusiastidel pole kusagilt sõnu otsida. Internetis avaldatud sõnaraamatud on viletsad (nt Tšernjavski, Vitali 2005. "Vad'd'a tšeeli (Izeõpõttaja)", 2000 sõna; http://vod.org.ua). Tatjana Jefimova eestvedamisel tegeletaksegi eri tekstide tõlkimisega vene keelde. Tatjana Jefimova kirjutas 12.09.2010, et nad tõlkisid neli muinasjuttu ja kavatsevad Anu Hvatova rahvalaule tõlkida. Üht-teist on ka kodulehel vatland.ru, aga kirillitsa kasutamine seal vadja keele kirjapanemisel on üllatav (nt “Куй мия казалин канайне”). Teisalt ehk polegi see nii üllatav, sest kodulehe lugejad, kes elavad Venemaal, mõistavad kirillitsas 
teksti paremini. Seega tekibki küsimus - kirjakeel nagu oleks olemas, aga kasutajad...

\section{Algupärane looming}

Algupäraseks võib pidada Jekaterina Kuznetsova 2010. aastal ilmunud värvimisraamatut "Vad'd'a krazgõttavõ cirja" (Kuznetsova, Muslimov 2010) ja Tatjana Jefimova toimetatud vadja kalendrit "Vad'd'a päivüzikko 2011" (Jefimova 2010). Värviraamatu lõpus on alfabeet, kuhu kuuluvad ka palataliseeritud sibilandid, r ja t', afrikaati $\check{c} / t \check{s}$ märgib $c$ ja $c$-d $t s$. Raamatus rändab pääsuke üheteistkümnel lehel ja seda, mida ta lennul näeb, iseloomustavad lihtsad laused. Esilehel on veel kolm sissejuhatavat lauset: $\mathrm{Vad}^{\prime} \mathrm{d}^{\prime} a-$ maa on maa Soomõ Lahõ lõunad rannõz. Se on kõvi lusti. Kassõnn ammuzõlt aigalt eletä vad'd'alaizõd. 'Vadjamaa on maa Soome lahe lõunarannal. See on väga ilus. Siin elavad ammusest ajast vadjalased.'

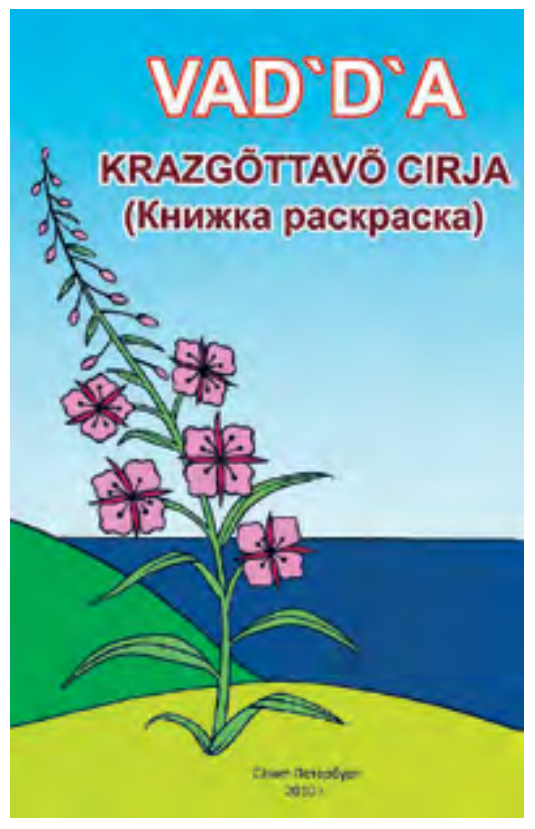

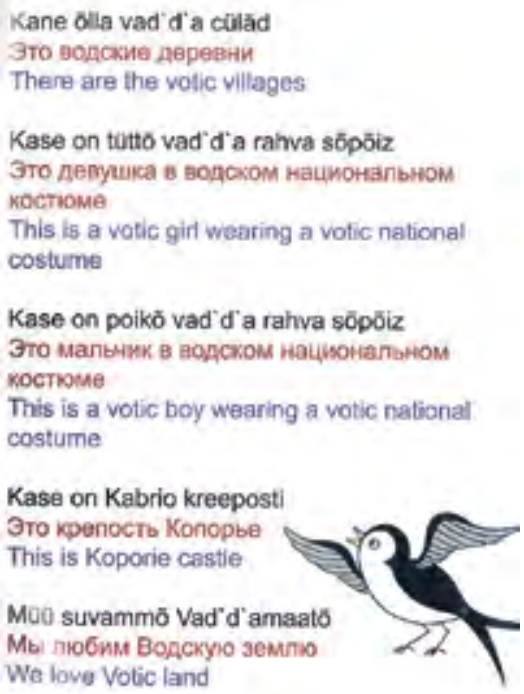


Tekst on järjekindlalt Jõgõperä keelekasutusele iseloomulik ja paistab silma purismiga. Näiteks lauses Vad'd'a rahva loomõ on karu on sõna loomõ selgelt eesti laen, mis sõnaraamatus esineb märkega Tsv, s.o ainult D. Tsvetkovilt kirja pandud. Autor pole tahtnud kasutada vene laenu zveeri. Ka mõjub eestipärasusena sõna rahvas (gen. rahva) kasutus. Ilmselt oleks parem vad'd'a väe. Lõpus esinevad kõik raamatus olnud laused ka vene- ja ingliskeelsete tõlgetega.

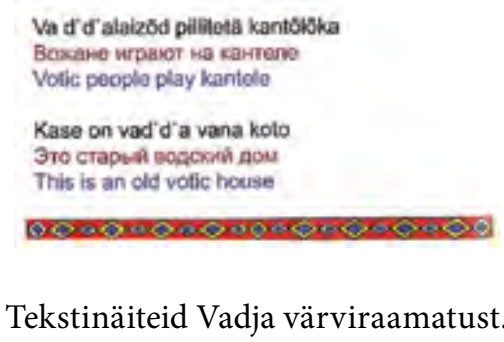

Tatjana Jefimova koostatud kalender "Vad'd'a päivüzikko" on vene- ja vadjakeelne. Pühade valimisel on abiks olnud Paul Ariste "Vadja rahvakalender" (Ariste 1969). Nii vene- kui vadjakeelse väljaande keeleline korrektor on Mehmet Muslimov. Kalendris esineb head sõnaloomet. See kajastub juba sõnas päivüzikko, mida "Vadja keele sõnaraamatus" pole. Originaalteksti keel on enamasti Liivtšülä-Luuditsa murdele iseloomulik, nt tuhkapäive, tõinpäive, kõlmõspäive... 'esmaspäev, teisipäev, kolmapäev'. Esmaspäeva tähistav sõna tuhkapäive tekitab praegustes kõnelejates segadust ja "Vadja keele sõnaraamat" (1990: 212) esitabki Vaipooles sõnakuju esimespäivä; tuhkapäivä oli iseloomulik orko-murderühma küladele. Kohati esineb ka ka Jõgõperäle iseloomulikku lõpukaolisust. Ariste kalendriraamatu tsitaadid on säilitanud originaalkuju, nt on septembris Spiridonipäeva (spirka) iseloomustus Lempolast kirja pandud (Ariste 1969: 141), kalendritekst jäljendab seda vigaselt. Kalendris on ära toodud ka 13. oktoober - vad'd'a rahva päive 
'vadja rahva päev' - see on päev, mil vadjalased lülitati Venamaa väikesearvuliste põlisrahvaste nimistusse. Hulgaliselt esineb huvitavaid pilte nii tänapäeva vadjalastest, vadjalastele olulistest iskutest (Paul Ariste Helsingi ülikooli audoktoripromotsioonil veebruarikuus, Dmitri Tsvetkov oma sünnikuul augustis), museoloogilistest esemetest, vanu arhiivifotosid küladest jne. Koostajad on järginud teaduslikku täpsust illustratsioonide kommenteerimisel. Tõlgetes on mõningaid vigu. Igatahes on tegu omamoodi teatmeteosega, mis teemaga tuttavate inimeste südame soojaks teeb.

Ferenc Válóczy ingliskeelsel kodulehel on vadjakeelsed tekstid ja luuletõlked, aga kuna need on kirillitsas, on nende kirjaviisi kohta raske midagi arvata (http://www.geocities.com/Vienna/3259/ index.html).

Huvitavaks katseks on Enn Ernitsa vadjakeelne luuletus (Ernits 2006a : 219):

Uni-lintu lensi kaukaalt, Liblikas see lendas kaugelt, Entši-lintu manalassa. Hingelind see manalast.

Minuu Mar'a aika koollu, Minu Maarja ammu koolnud,

Tuli-kutsub ómaa meessä. Tuli - kutsub oma meest.

\section{Vadja keele lugemise ja kirjutamise probleemidest praktikas}

\section{Keelekursused}

2010. ja 2011. aasta suvel korraldas Heinike Heinsoo Jõgõperäl neljapäevased vadja keele kurused "Vunukassa baabuškassaa" ("Lapselapsest vanaemani”). Osalejaid oli paarikümne ümber. Rohkem olid esindatud vanaemad, lapselapsi oli vähe ja nende pealehakkamine tagasihoidlikum. Osales ka kolm vadja keele kõnelejat. Mõnel osalejal oli teatud passiivne vadja keele oskus olemas, nt Sergei Jefimovi õde Nina Vittonk, Taissa Mihhailova, Tatjana Naumova said üllatavalt hästi aru vanasõnadest ja muust tekstist. Kursusi on kajastanud Inkerin Kulttuuriseura väljaanne "Inkerikot ja vatja- 
laiset 2010” (Ifolor), kus tekstid ja fotod on pärit Aune Kämäräinenilt, samuti tema kirjutised ajakirjas "Inkerin Kulttuurikanava" (Kämäräinen 2010, 2011).

Kursustel kerkis lugemise ja kirjutamise probleem teravalt esile. Esimesel kursusel 2010. aasta suvel oli ópetus liiga klassikaline ja eeldas üsna palju kirjutatud teksti kasutamist ja ka ise kirjutamist. Mõlemad tekitasid raskusi. Siiski läks üllatavalt hästi rahvalaulutekstide lugemine ja laulmine, samuti lühemad tekstijupid, nt vanasõnad ja mõistatused. Järgmistel kursustel 2011. aastal oligi

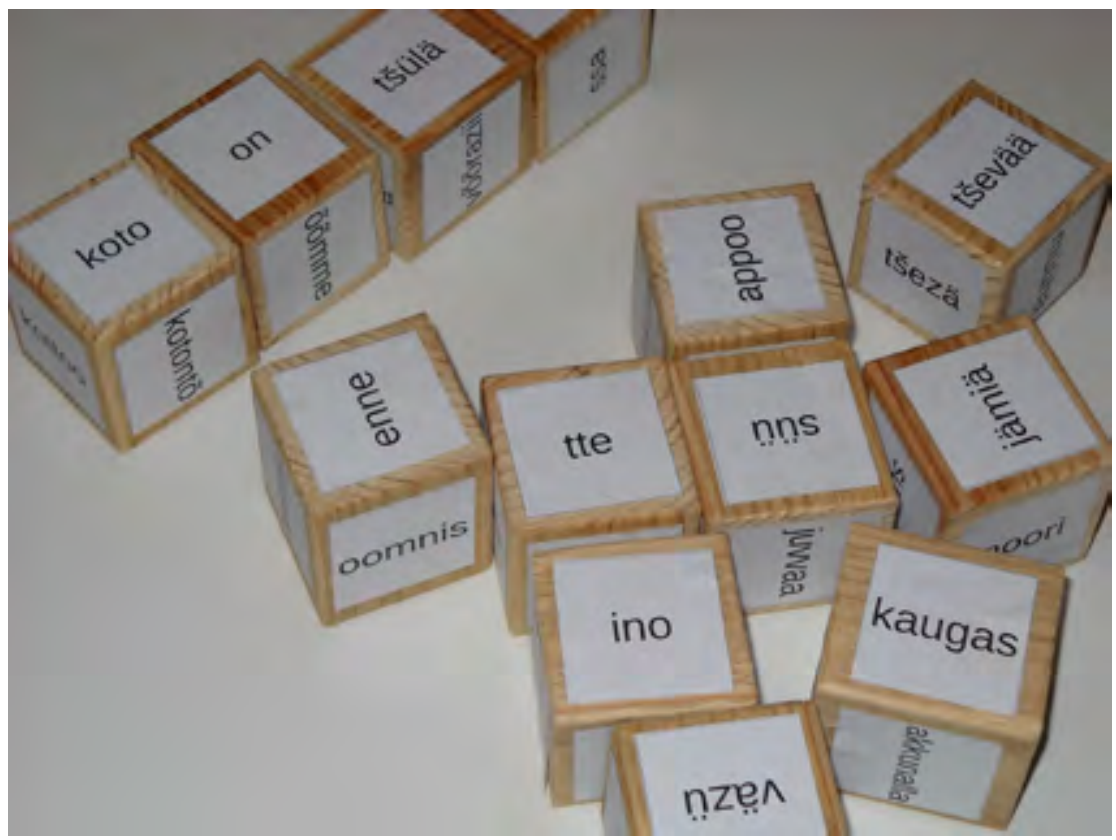

Sõna- ja morfeemikuubikuid oli 2 komplekti, kummaski 36 klotsi. Võistkonnad panid kokku lauseid.

vadja keeles kirjutamine viidud miinimumini, kuna kogu materjal oli trükitud kujul olemas. Lisaks soodustas õppimist tugev mänguline element - morfeemikuubikud, värvilised kaardid inimeste 


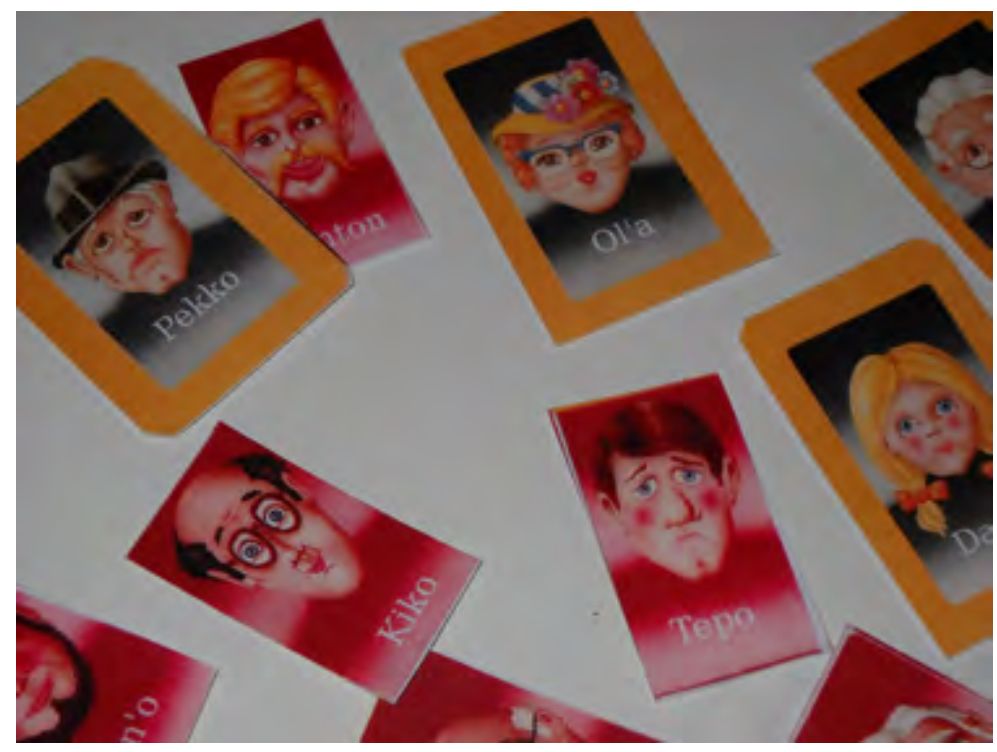

Mängijad pidid vastasmängija kirjelduse järgi ära arvama, kelle pilt on tema käes oleval kaardil.

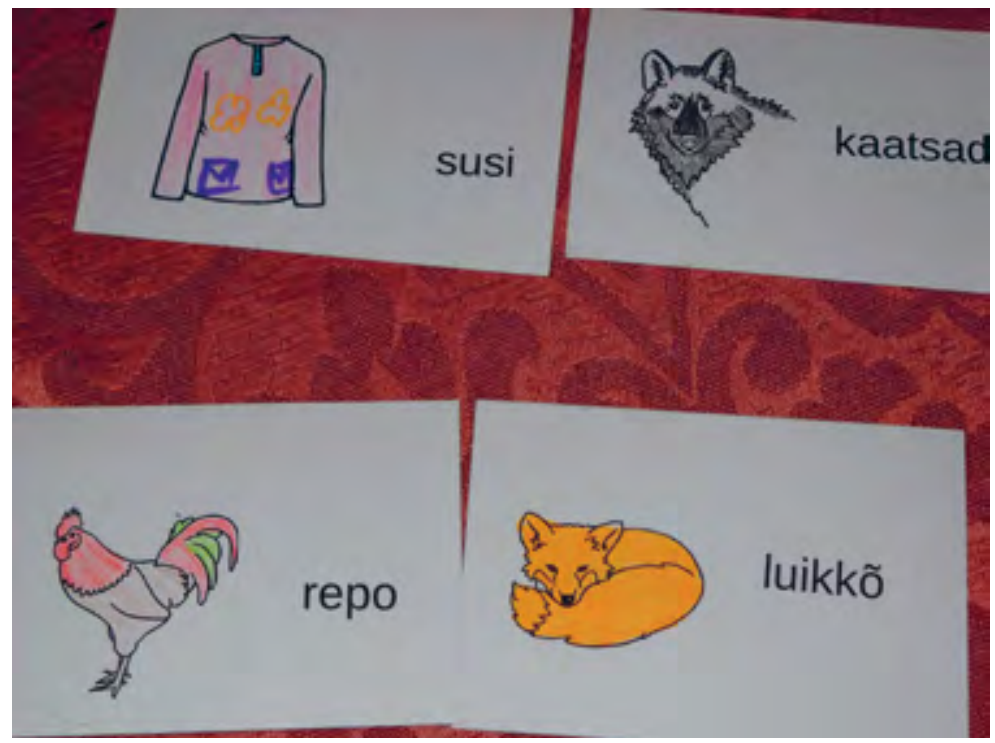

Sõna- ja pildilotos tuli piltide ja sõnadega kaardid õigesti kokku viia. 
kirjeldamiseks ja äraarvamiseks, tükkideks lõigatud mõistatused, valmis sõnasedelid, sõna- ja pildilotod jne.

Aga ise vadjakeelset teksti üles kirjutama olid võimelised vaid Zina Saveljeva, noor isuri taustaga Soikkola koduloomuuseumi töötaja Nikita Djatškov ja veidi ka Nina Jefimova. Kasutatud tekstid olid järjekindlalt vadja keele sõnaraamatus kasutatavas kirjaviisis ja see on nüüd ka vilja kandnud, sest kodulehele ongi ilmunud uus alfabeet. Seega - peale suuri sünnitusvalusid on praegune vadja kirjakeel jõudnudki sellisele kujule, nagu seda kasutab alates 1990. aastast ilmunud sõnaraamat. Näib, et jalgratas on taasleiutatud.

Igatahes toimisid keelekursusel hästi mängud, kus ise polnud vaja midagi kirjutada.

\section{Tarbeteksti loomine}

2011. aasta novembris paigutati helifailina vadja veebilehele vatland.ru Sergei Jefimovi (s 1954) vadjakeelne suuline tekst "Virtuaalne jalutuskäik Luuditsas". Jefimov kommenteerib vanu fotosid ja kõneleb sellest, mis vanasti külas oli: http://vatland.ru/toponim/ vm/luzici.php.

Tekst on algupäraselt olnud venekeelne, esitaja on selle vadja keelde tõlkinud ja endale vadja keeles kirillitsat kasutades kirja pannud. Tema loetud teksti vead tulenevad ennekõike sellest, et ta pole tõlgitud teksti osanud üles märkida ega hiljem ülesmärgitut maha lugeda. Tatjana Jefimova sõnul ongi selliseid ülestähendusi raske mõista. Seetõttu esineb tekstis üllatavalt palju algelisi astmevahelduse vigu, valet käändekasutust ja muid selliseid üsna primitiivseid möödapanekuid, mida Jefimov tavalises kõnes ei teeks. Jefimov on osalenud mõlemal vadja keele kursusel, aga tema osalus tundus olevat üsna passiivne.

Küsitluste puhul olen saanud omakäelisi vadjakeelseid kirjapanekuid Zina Saveljevalt. Saveljevat on segadusse ajanud vadja kirjakeeles toimunud muutused. Kohusetundliku inimesena, kes on ka Eestis kõrgkoolis õppinud, on ta proovinud muutustega kaasas 
käia. Ja see on teda endas kahtlema pannud ja segadusse ajanud. Zina Saveljeva konsulteeris "Uurali keelte sõnastiku" vadja osa. Nüüd on ka see teos Vaipoole murdes ja sedagi võiks tarbetekstiks pidada (UKS 2004, 2007). Sõnaraamatu sisu paneb külakeelt kõnelevaid inimesi kohati muigama ja paljud konventsionaalsused kõlavad vadja keeles kunstlikult. Esimese osa puhul oli konsultandiks Tatjana Prokopenko (1935-2006).

Originaaltekstiks võib pidada Zina Saveljeva jõulukaarti.

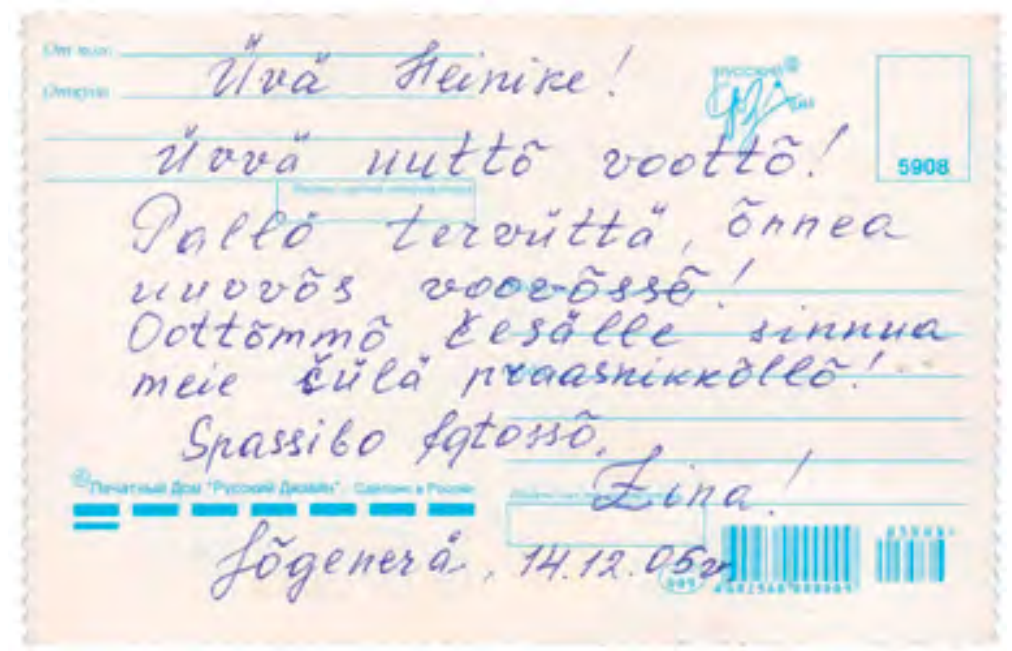

Zina kirjaviis oli juba 2005. aastal selline, nagu praegu kasutusele on tulemas. Nii näib, et kirjakeel hakkab ilmet võtma, aga kas vadjalaste hulgas selle kasutajaid leidub, on kahtlane. Siiski on tore, et valmis tekstide lugemine õnnestub vadja keele kõnelejatel üsna hästi. Kirjakeele juurdumisele aitab kaasa vene-vadja sõnaraamatu ilmumine. Loodetavasti soodustab sõnaraamat ka vadjakeelse originaalloomingu teket. Loomulikult oleks aeg ka koostada algõpetuse tarvis lugemik. Ja kindlasti tuleks langetada otsus nt sõnalõpu vokaalide suhtes. Jõgõperäs on sageli sõna lõpust $a / \ddot{a}$ kadunud, Liivtšülä-Luuditsa dialektis esineb aga sel puhul õ/e. Keelekursus- 
tel oli sel teemal sageli ütlemist ja taas tuli selgitada, et kirjakeel on kokkuleppeline keel ega ole mitte kellegi emakeeleks.

Viimastel aastatel on vadja liikumises agaralt kaasa löönud Soikkola isuri muuseumis töötav Nikita Djatškov (s 1988). Mõned näited kirjavahetusest käesoleva loo autoriga (kirjavahetuse algatajaks oli Djatškov):

5.03.2012

Tere, Heinike!

Jõgõperälaizõd cyzytti minnua sillõõ jutõlla, jott janvarikuuz Ol’o Borisov kooli väl'l'ää. Täll õli kahõsacümment vootta. Tätä avvõttii Jõgõperä kalmoillõõ. Mejjee nõmad (Marina, Zina täti, Vera täti) saatõtaa sillõõ tervyttä. Kui teill d’elad õllaa? Kui tyy elätt?

Nikita Djackov

'Jõgõperälased palusid mul sulle öelda, et jaanuaris suri ära $\mathrm{Ol}^{\prime}$ o Borissov. Ta oli 80-aastane. Ta maeti Jõgõperä surnuaeda. Meie omad (Marina, Zina-tädi, Vera-tädi) saadavad sulle tervisi. Kuidas teil asjad on? Kuidas te elate?'

Kirjaviis järgib Muslimovi varasemaid kirjapanekuid, lõpuvokaalide osas on enamasti kasutusel Jõgõperäle iseloomulik variant. Vastasin kirjutajale, üritades kasutada järjekindlalt Liivtšülä-Luuditsa murret. Nikita järgmine kiri (6.03.12) on selline:

$\mathrm{Ni}$, kase kal'endar' nii kõvassi suuri, miä cüsüzin heilte tehä peenepi, no vasattii što nõissa tecemä niku i menn voottõ. Se eb õõ yvä, no mitä tehä!? Võib õlla tulõval leeb parõpi.

Se on üvä veesti, miä vähäze toož õpõtan lahsii ižoraa ceelte Viistinaz, kui tunnõn da võin. Kutsuttii Jaamaasõõ, da seel' toož õli ühs zanjatije ižoraa ceelel. A Jõgõperä škouluz nüt jõka esimes' -päivä laulamm vad'd'aa ceelel lahsiikaa da proovammõ õppõssa vad'd'aa ceelte. Oottõõmmõ teitä!Anna antõssi jott mill on nii pal'l'o ošibkoi.

Mikitta. 
Siin vastuses on jutt isuri 2012. aasta kalendrist ("Ižorin kalendar' 2012").

'Nii, see kalender (on) nii väga suur, mina palusin neil teha väiksem, aga vastati, et hakatakse tegema nagu eelmisel aastal. See ei ole hea, aga mida teha. Võib-olla järgmisel tuleb parem. See on hea teade, ma ka veidi õpetan lastele isuri keelt Viistinas, nagu oskan ja suudan. Kutsuti Jaamasse (Kingisseppa), ja seal on ka üks tund isuri keeles. Aga Jõgõperä koolis laulame nüüd igal esmaspäeval vadja keeles lastega ja proovime õppida vadja keelt. Ootame teid! Anna andeks, et mul on palju vigu.'

Djatškovi keelekasutus muutus teises kirjas Liivtšülä-Luuditsa murde sarnasemaks, aga ta hoidis kinni $c$ ja $y$-grafeemi kasutusest. Tõsi, viimasest mitte alati. Seega võib öelda, et vadja kirjakeel hakkab kasutust saama ja üksteisemõistmine oli täielik.

Enda kohta kirjutab Nikita Djatškov (12.03.12):

A mitä võib cirjuttaa enesse?! Miä süntüzin Petteriz 1988 vooõz. Da õppõzin Petteriz. Vanõpad eletää seel'. A kõnz miä lõpetin õppõssa universitetaz, minnua kutsuttii tehhä tüüt Viistina muzejaa. Vot i menin Petterisse vällää da nõizin elämää Jõgõperää cüläz minuu ämmäl. Miä en õõ vad'd'alain. Võib õll minuu vanad sukulaizõd õltii vad'd'alaizõd Jõgõperälte, sitä miä en tää, no rohkõpi kõik õllaa soikkolaizõd (ižorid) da venäläized. Taattõ on ižori Jõgõperälte, a emä on venäläin Petterisse. Millõõ näüttiib ellää cüläz, siin saab veel pajattaa ja läätä. $\mathrm{Da}$ cüläz eläd niku voolil.

'Aga mida võib kirjutada endast?! Ma sündisin Petteris (Peterburis) 1988. aastal. Ja õppisin Peterburis. Vanemad elavad seal. Aga kui ma lõpetasin ülikoolis õppimise, kutsuti mind tegema tööd Viistina muuseumisse. Vaat ja läksingi Petterist (Peterburist) ära ja hakkasin elama Jõgõperä külas oma vanaema juures. Ma ei ole vadjalane. Võib-olla minu sugulased olid vadjalased Jõgõperält, seda ma ei tea, aga rohkem on kõik soikkolalased (isurid) ja venelased. Isa on isur Jõgõperält, aga ema on venelane Petterist (Peter- 
burist). Mulle meeldib elada külas, siin saab veel vadja ja isuri keelt kõnelda. Ja külas elad nagu vabalt.'

Afrikaadi märkimise kohta ütleb ta: Nii, mill ôllaa mokomad bukvõd, no müü kassin cirjutammõ "tš" - niku "c". En tää, õikassi kase vai eb õ õ, no minnua ópõtattii cirjuttaa nii viisii. 'Nii, mul on

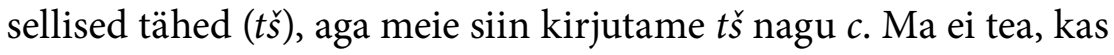
see (on) õigesti või ei ole, aga mind õpetati niimoodi kirjutama.' Nikita Djatškov käis Muslimovi juures vadja keele eratunde võtmas.

Seega kirjakeel toimib - vaatamata teatud ühtlustamisvajadusele. 1967. aastal kirjutas Ariste oma päevikus, et Luuditsas ja Liivtšüläs kõneldakse igas majas läänemeresoome keelt ehk vadja keelt, isuri mõjudega vadja keelt või siis vadja mõjudega isuri keelt (VP 2005: 97). Praegu üheski majas vadja keelt ei kõnelda, sest üksi pole mõtet rääkida, aga just selline keelekuju nagu Vaipoolele iseloomulik, on nüüd kirjakeele aluseks. Seega pole mõtet arutada, kuivõrd õige see keel on. See on maailma viimaste emakeelena vadja keelt kõnelevate inimeste keel.

\section{Kirjandus}

Ariste, Paul 1960. Tänapäeva vadjalastest. - Etnograafiamuuseumi aastaraamat XVII, lk 203-224.

Ariste, Paul 1969. Vadja rahvakalender. Tallinn: Eesti Teaduste Akadeemia.

Ernits, Enn 2006a. Vadja keel ja kultuur ajalookatlas. - Õpetatud Eesti Seltsi aastaraamat 2004-2005. Tartu: Õpetatud Eesti Selts, lk 219-241

Ernits, Enn 2006b. Об обозначении звуков в водском языке. - Linguistica Uralica 1, c. 1-9.

Ernits, Enn 2009. Vadja haritlane Dmitri Tsvetkov. Tartu: Eesti Kirjandusmuuseumi Teaduskirjastus.

Ernits, Enn 2010a. Väärt lugemisvara vadja muistendite ja muinasjuttude näol. - Keel ja Kirjandus, lk 857-860. 
Ernits, Enn 2010b. Vadja kirjaviisist ja sõnaloomest. - ESUKA - JEFUL 2010, $1-1,1 \mathrm{k} 41-56$

Heinsoo, Heinike 2004. Investigating obsolence: Votic. - Fenno-Ugristica 26, pp. 10-16.

Heinsoo, Heinike, Kuusk, Margit 2011. Neo-renaissance and revitalization of Votic - who cares? - ESUKA - JEFUL 2011, 2-1, pp. 171-184.

Ižorin kalendar' 2012. Kuvat Harakka ja Ko, kalendar'an tekijä: Kiru, sanat: Onderen Mikitta, pri poderžke: Inkerin Kulttuuri Seura (Helsinki).

Jefimova 2010 = Ефмова, Татьяна. Vad' d'a päivüzikko 2011. - АНО Общество водской культуры. Санкт-Петербург.

Kettunen, Lauri, Posti, Lauri 1932. Näytteitä vatjan kielestä. Suomalais-Ugrilaisen Seuran Toimituksia LXVIII. Helsinki.

Kettunen, Lauri 1945. Tieteen matkamiehena: Kaksitoista ensimmaista retkeä 1907-1918. Porvoo, Helsinki: Söderström.

Konkova 2009 = Предания и сказки водского народа. Vad'd'aa rahvaа jutud ja kaazgad. Серия “Фолъклор коренных народов Ленинградской области”. Составитель и автор вступительного раздела О. И. Конькова. СанктПетербург: Музей антропологии и этнографии им. Петра Великого, (Кунсткамера). Џентр коренных народов Ленинградской области.

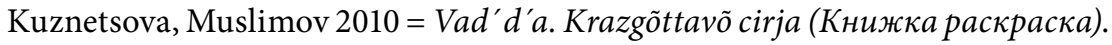
Художник Е. Кузнецова, текст: М. Муслимов, Е. Кузнецова. СанктПетербург.

Kämäräinen, Aune 2010, Vatjan kulttuuri heräilee. - Inkerin Kulttuurikanava. Inkerin kulttuuriseuran jäsenlehti 2, s. 4-6.

Kämäräinen, Aune 2011. Uudet konstit vauhdittavat vatjan kurssia. - Inkerin Kulttuurikanava. Inkerin kulttuuriseuran jäsenlehti 2, s. 4-5.

Markus, Rožanskiyi 2011 = Маркус Е. Б., Рожнский И. 2011. Сорвеменный водский язык. Тексты и грамматический очерк. Том I, II. Санкт-Петербург: Нестор-История.

Mirenkov 2002 = Мренков, Владимир 2002. Проблемы сохранения ижорского языка. - Studia Slavica Finlandesia XIX, Helsinki, c. 206-211.

Mustonen, O.A.F. 1883. Muistoonpanoja Vatjan kielestä. - Virittäjä I, s. 144188. 
Posti, Lauri, Suhonen, Seppo 1964. E. N. Setälän vatjalaismuistiinpanot. Memoria Saecularis E. N. Setälä. SUST 135.

Romanova 2010 = Романова, Яна. Водь. Краткая история еще одного исчезающего народа. - Русский Репортер 12.10.2010, 40 (168), с. 55-66.

Talve, Ilmar 1990. Matka vatjalaisiin. - Inkerin teillä. Kalevalaseuran vuosikirja 69-70. Helsinki, s. 46-66.

Tsvetkov, Dmitri 1995. Vatjan kielen Joenperän murteen sanasto. Toim. J. Laakso. Lexica Societatis Fenno-ugricae XXV. Helsinki.

Tsvetkov, Dmitri 2008. Vadja keele grammatika. Koost. ja toim. Jüri Viikberg. Tallinn: Eesti Keele Sihtasutus.

UKS 2004, 2011 = Uurali keelte sõnastik. Fenno-Ugria Asutus.

Vađđa kaazgad 2003 = Vađđa kaazgad. Воские сказки. Перевод, составление и обработка М. Муслимов. Е. Кузнецова, Е. Николаева, А. Гореликов, С. Ефимов, Т. Ефинова. Санкт-Петербург.

VP 2005 = Paul Ariste Vadja päevikud 1942-1980. Litteraria: Eesti kultuuriloo allikmaterjale 22. Koostanud, kommenteerinud ja saatesõna kirjutanud ErgoHart Västrik. Toimetanud ja järelsõna kirjutanud Peeter Olesk.

\section{Summary}

\section{Votic language - spoken and written}

The article presents observations on the language of the last present-day speakers of Votic language. There are five native Votians who live in their native villages, in Jõgõperä, Liivtšülä and Luuditsa, and still speak rather correct Votic. Historically, Votians have not had written language of their own, neither have they ever received any education in their mother tongue. The Association of Votic Culture has initiated the creation of Votic literary language in co-operation with linguists. The work has been going on for two decades, and the results are taking shape. Since 2003 the Votic literary language has been tested, mainly in translations of fairy tales 
from the Votic oral literary heritage (a collection of fairy tales in Votic and in Russian, "Vađđa kaazgad. Водские сказки" was published in 2003). A colouring book "Vad'd'a. Krazgõttavõ cirja" and Votic calendar for the year 2011 "Vad'd'a päivüzikko 2011" were published in 2010. The language courses carried out by the author of the article in 2010 and 2011 demonstrated that the aged villagers who have been educated in and and read in Cyrillic, have problems in mastering the Votic written language using Latin alphabet.

Key words: Declining language, identity, written language, dialects, formation of written language, translation, original creation. 


\title{
Vepsakeelsest kirjandusest
}

\author{
Enn Ernits
}

doi:10.7592/PS/28-6ernits

Teesid: Kirjutises võetakse vaatluse alla vepsakeelne trükisõna funktsionaalsest liigitusest lähtuvalt. Vepsa kirjanduse eelperioodil (1853-1931) ilmus ühtekokku kuus vepsakeelse tekstiga teost (neist kolm vepsa raamatut). Esimesel perioodil (19321937) nägi päevavalgust 32 vepsakeelset raamatut. Neist enamiku moodustas õppekirjandus. Vaheperioodil (1938-1988) avaldati ainult neli teadusraamatut.Teisel perioodil (alates 1989. aastast) on publitseeritud 66 vepsakeelset teost. Neist 27 kuuluvad ilu-, 17 õppe-, 9 vaimuliku ja 9 teatmekirjanduse valda. Keskmiselt ilmub kolm vepsakeelset raamatut aastas (osaliselt kakskeelsed). Erinevalt esimesest ajajärgust osutatakse teisel perioodil suurt tähelepanu ilu- ja vaimulikule kirjandusele, sh lastekirjandusele. Alates 1993 ilmub Karjalas kakskeelne ajaleht "Kodima" ja 2011. aastast vepsakeelne lasteajakiri "Kipinä".

Märksõnad: vepsakeelne kirjandus, raamatud, perioodika, kirjanduse funktsionaalne liigitus, ilukirjandus

\section{Sissejuhatuseks}

Vepslased on läänemeresoome keelerühma kuuluv sugulasrahvas. "Eesti entsüklopeedias" toodud 2002. aastal toimunud rahvaloenduse andmeil oli neid 8240. Vepslased elavad peamiselt Karjalas Äänisjärve edelarannal (arvult üle 4800) ning Vepsa kõrgustikul Leningradi oblastis (veidi üle 2000), tunduvalt vähem Vologda oblastis (alla 500) ja mujal. 2010. aasta rahvaloenduse andmeil 
oli vepslasi alles veel 5936 ja vepsa keele valdajaid 3613. Seega oli kümne aastaga rahvaarv kahanenud 28 ja keeleoskajate arv isegi üle 37 \% (Prozes 2012: 32).

Vepsa keelel on kolm murret: Karjalas põhja- ehk äänisvepsa murre, Leningradi ja Vologda oblastis keskmurre ning Leningradi oblastis viimasest lõuna pool lõunavepsa murre. Vepsa kirjakeel põhineb keskmurdel, mida räägitakse kõige laiemal maa-alal. Vepsa kirjasõna ajaloos eristatakse kaht põhiperioodi: 1930. aastatel olnud esimest ja 1989. aastal alanud teist perioodi (Zaitseva 2005b: 181). Lisaks ei saa mööda ka eel- ja vaheperioodist. Vepsakeelse kirjanduse ajaloost 1990. aastate lõpuni on teinud venekeelse sissevaate Karjala teadlased Irina Spiridonova (2000) ja Nina Zaiceva (2000b). ${ }^{26}$ Meil on vepsa kirjandust Karjala kirjanduse osana lühidalt vaadelnud Jaan Õispuu (2003).

Artiklis antakse funktsionaalsest liigitusest lähtuvalt ülevaade XIX sajandi teisest poolest 2011. aasta lõpuni üllitatud vepsakeelsetest ilukirjandus-, tarbe- jt tekstidest. Suuremat tähelepanu pööratakse vepsakeelsetele raamatutele. Nende hulgas mainitakse ka mitmekeelseid sõnastikke ja teaduslikus transkriptsioonis publitseeritud keeleainest. Tähelepanuta on jäänud muukeelsed vepsa keele õpikud ja teadustööd. Väga vähesel arvul vaadeldakse käesolevas kirjutises ajakirjanduses ja raamatutes avaldatud lühitekste (luuletusi, muinasjutte jm). Põgusalt on peatutud vepsa loomingu tõlgetel teistesse keeltesse. Sissevaadet aitab olulisel määral täiendada kirjanduse loetelu, mis on samaaegselt ka vepsa keelt sisaldavate teoste bibliograafiaks. Selleks, et saaks ettekujutust käsitletavate raamatute mahust, on bibliokirjele lisatud lehekülgede arv. ${ }^{27}$ Bibliografeerimisel on peale de visu kontrolli kasutatud interneti vahendusel Karjala Vabariigi Rahvusraamatu elektronkataloogi, kaht bibliograafiat (vt internetiallikad), samuti kõikvõimalikke

26 Vepslaste nimed kirjutatakse käesolevas artiklis vepsa kirjaviisist lähtuvalt $c$ ja ̌̌, mitte ts ja tš abil.

27 Andmete kuhjamise vältimiseks on loobutud illustreerijate ja formaadi märkimisest. Lehekülgede arvu tähistamine on de visu kontrollimise võimaluse sagedase puudumise tõttu ühtlustamata. Mitmel juhul pole teada, kummas keeles pealkiri asub kirjes esikohal. 
allikaid üksikteoste kohta. Tärniga on märgitud need kirjandusallikad, mis pole vepsa raamatud. Nende alla mahuvad eespool mainitud keeleõpikud ja teadustööd, lisaks enamik mitmekeelseid (rohkem kui kaht keelt sisaldavaid) kogumikke, milles vepsa keele osakaal on suhteliselt väike. Muide, erinevalt vepsakeelse kirjanduse mõistest on vepsa kirjandus laiem, hõlmates ka vene ja soome keeles kirjutatut.

\section{Eelperiood}

Vepslased avastas teadusmaailmale soome keeleteadlane Andreas Johan Sjögren suhteliselt hilja, alles 1824. aastal esmakordselt nende juures viibides. Esimese teadustöö vepsa keelest kirjutas eepose "Kalevala" koostaja Elias Lönnrot, kes kogus ainest Äänis-Vepsast ja avaldas rootsikeelse väitekirja pealkirja all "Põhjatšuudide keelest" (Lönnrot 1853: 3-28). ${ }^{28}$ See sisaldas peale keelekirjelduse seitset muinasjuttu vepsa keeles ja nende tõlget soome keelde, lisaks vanasõnu ja mõistatusi tõlgetega ning katkendi Matteuse evangeeliumist (Zaiceva 1981: 9).

Kuus aastat hiljem üllitas soome keeleteadlane August Ahlqvist endakogutud keskvepsa materjalil põhineva "Ülestähendusi põhjatšuudi keelest" (Ahlqvist 1859). Teos sisaldab peale grammatilise ülevaate mitmesuguseid tekste ja väikese vepsa-rootsi sõnastiku. Kümme aastat hiljem avaldas A. Ahlqvist vepsa tekstid ja sõnastiku ka läänemeresoome keelte kogumikus (Ahlqvist 1869: 170188, 239-259). Eelperioodist on teada ka Äänis-Vepsast pärinenud vene rahvusest kooliõpetaja Pavel Uspenski väike vepsa-vene sõnaraamat (Uspenski 1913; vt Inno 1991). See kuulub teatmekirjanduse hulka. Samuti jääb eelperioodi teaduslikus transkriptsioonis publitseeritud kaks köidet lõunavepsa murdetekste, mille kogus ja andis koos tôlgetega välja soome keeleteadlane Lauri Kettunen $(1920,1925)$.

28 Väitekiri on paar korda hiljemgi avaldatud (vt Lönnrot 1991, 2002). 


\section{Esimene periood}

Vepsa kirjakeel loodi 1930. aastate alguses nn kultuurirevolutsiooni laineharjal. Vepslasi oli tollal ainuüksi Leningradi oblastis üle 24 000. Vepsa lapsi õppis 49 alg- ja 5 keskkoolis, kuid kõikjal ei saadud kohe sisse viia emakeele õppimist, sest paljudes kohtades puudusid vepslastest õpetajad. Paraku pidid äänisvepslased nagu karjalasedki kasutama soome keelt (Mullonen 1967: 106, 108; Zaiceva 1989: 129 jj). Esimene vepsa aabits (koos lugemikuga) ilmus 1932. aastal ja eraldi aabits neli aastat hiljem (Bogdanov, Hämäläinen, Mihkijev 1932; Andrejev, Hämäläinen 1936). Seega on vepsa kirjandus ja kirjakeel üsna noored.

Esimesel perioodil koostati põhiliselt algkooliõpikuid. Ühtekokku ilmus Venemaal 31 raamatut. Nende seas oli koos aabitsatega 28 õpikut, millest 9 ópetasid keelt ja kirjandust (Andrejev 1934a, 1934b, 1935, 1937; Andrejev, Bogdanov, Petuhov, Silin 1933; Andrejeva 1936; Bogdanov, Loginov, Bol'šakov jt 1936; Hämäläinen, Andrejev 1934, 1935). Ilmus ka õppekirjandusega seotud, kuid tarbekirjanduse valda kuuluv ilukirja õpetamise programm (Programmad 1937). Keeleõpikute-lugemike autoriteks olid peamiselt vepslasest kooliõpetaja Fjodor Andrejev, vepslasest teadlane, vepsa tähestiku looja Nikolai Bogdanov ning ingerisoomlasest Leningradi ülikooli dotsent Matti Hämäläinen. Stalinismi perioodi lugemikud olid tugevasti üleideologiseeritud. Nende ilukirjanduspalad kujutasid endast peamiselt tõlkeid vene keelest ja olid algkooliõpilaste jaoks kohaldatud.

Mõne aasta jooksul jõuti anda välja ka 10 aritmeetika (Popova 1933a, 1933b, 1934a-d, 1936, 1937a-c), 4 loodusteaduse (Tetyrev 1934, 1935, 1937a, 1937b) ja 3 maateaduse õpikut (Terehova, Erdeli 1934, 1936a, 1936b). Kõik mittekeelealased õpikud olid tõlgitud vene keelest. Peale lugemikes sisalduvate ilukirjandustekstide ilmus vaid üks õhuke tõlkeline juturaamat vähetuntud vene autori sulest (Grigor'jev 1937). Kogu õppekirjandus anti välja Leningradis. 1936. aastal nägi päevavalgust väike vepsa-vene sõnaraamat, mis sisaldas ligikaudu 3000 sõna (Hämäläinen, Andrejev 1936). 
1930. aastate teisel poolel kirjakeele areng järsku katkestati. Järgnesid repressioonid, üleminek vene õppekeelele ja vepsakeelsete õpikute põletamine (Zaiceva 1997: 117). Esimesse perioodi kuulusid ka Soomes Lauri Kettuneni ja Paavo Siro kogutud vepsa tekstid teaduslikus transkriptsioonis koos tõlgetega (Kettunen, Siro 1935).

\section{Vaheperiood}

Järgnevalt eristub vepsa kirjasõna ajaloos pool sajandit kestnud nn vaheperiood (1938-1988), mil Soomes ilmus vaid kaks ja Venemaal üks vepsakeelne, kuid soomeugri transkriptsioonis tekstikogumik tõlgetega. Neist esimese ainestik oli tegelikult kogutud juba XIX sajandi lópul keeleteadlaste E. N. Setälä ja J. H. Kala poolt (Setälä, Kala 1951). Ka vaheperioodi lópu poole välja antud A. Sovijärvi ja R. Peltola tekstid olid kirja pandud juba varem (Äänisvepsän 1982). Leningradisüllitatud tekstikogumiku jaoks olid materjali kogunud kõigist murretest Petroskoi lingvistid Maria Zaiceva ja Maria Mullonen (Zaiceva, Mullonen 1969). Samad keeleteadlased koostasid ka mahuka, üle 700-leheküljelise vepsa-vene sõnaraamatu, taaskord transkriptsioonis (Zaiceva, Mullonen 1972). Sellised, iseenesest väga olulised üllitised, k.a sõnaraamat, mis kuulub teatmekirjanduse hulka, olid mõeldud esmajoones teadlastele. Kogumikes ilmunud tekstidest tahaksin mainida Eestis avaldatud põhja- ja keskvepsa muinasjutte (Ariste 1964) ning Soomes ilmunud vepsa tekste lähissugulaskeelte lugemikus (Virtaranta 1967: 111-136).

\section{Teine periood}

Seoses NSV Liidu lagunemisega hoogustus vepsa liikumine, mille käigus arendati vepsa kirjakeelt ja vepsakeelset kirjandust. See toimus paralleelselt karjala kirjakeelte arenguga (Õispuu 2003: 519). Vepsa kirjakeele taasrajaja oli keskvepslasest Karjala teadlane Nina Zaiceva. Ta tegeleb ulatuslikult ka keeleloomega. Nina Zaiceva on paljude õpikute ja luuletuskogude autor, samuti vaimulike jt teoste 
tõlkija. Toimetajana käib tema käe alt käib läbi peaaegu kogu vepsa kirjasõna.

Teise perioodi stiimuliks ja esimeseks pääsukeseks sai 1989. aastal ajakirja "Punalippu" (praegune "Carelia") vepsateemaline number, milles avaldati muu hulgas ka üht-teist ilukirjanduslikku (Mišin 2005: 194). Nii toimis ka ajaleht toonase nimetusega "Neuvosto-Karjala”.

Ilukirjandust ja rahvaluulet esindavad teisel perioodil, nagu see on noorele rahvuskirjandusele iseloomulik, peamiselt luuleteosed, ühtekokku 17. Temaatikas on tähtsal kohal mure rahva ja keele saatuse pärast, kodupaiga looduse ja emakeele ilu kajastamine ja väärtustamine. Suurem jagu luuletajaid pärineb Keskvepsast. Vepsa luule elavaks klassikuks loetakse Nikolai Abramovit, kelle sulest on ilmunud viis luuletuskogu, mis sisaldavad nii originaal- kui ka tõlkeloomingut: "Kolmkümmend kolm" (1994), "Kurgede aeg" (1999), vepsa- ja venekeelne "Ajame juttu, veli" (2005), vepsa- ja ungarikeelne "Topelt kolmkümmend kolm" (2010a) ning vepsa- ja prantsuskeelne "Metsade laulud" (2011). Esimene luulekogu ilmus, kui luuletaja sai 33-aastaseks. Abramov on valitud nii Venemaa kui ka Karjala Kirjanike Liidu liikmeks (Mišin 2005: 199).

Iseseisva luulekoguga on hakkama saanud veel teisigi, nagu tuntud äänisvepsa muinasjutuvestja Anastasia Logačova tütar Alevtina Andrejeva, kelle vepsa- ja venekeelset luulet sisaldav kogu kannab pealkirja "Kaseke" (Andrejeva 2003). Mihhail Bašnin on avaldanud samuti vepsa- ja venekeelse luulekogu "Vana peegel" (Bašnin 2003) ning Nina Zaiceva "Valge une süles" (Zaiceva 2008). Viimane neist on A. Mišini väitel esmakordselt tõstatanud vepsa luules naise teema (Mišin 2005: 208).

Tähelepanu väärib Soomes elava välisvepslase Raisa Lardot' looming. Autor kirjutab soome keeles peamiselt proosat, kuid 2001. aastal ilmus tema sulest äänisvepsa murdes luulekogu "Jäätunud linnud langevad okstelt" paralleeltõlgetega soome ja vene keelde (Lardot 2001; vt ka Mošnikov 2007).Vepsa poeetide (Maria Abramova, N. Abramovi, A. Andrejeva jt) palu sisaldab ka Kuhmos elava kirjamehe Markku Niemineni koostatud fotoalbum "Kodu- 
kant Vepsamaa" (läheb ka kunstiraamatute kirja), samuti Nina Zaiceva toimetatud "Värske tuul" (Nieminen 2003; Zaiceva 2008). Siinkohal ei saa jätta nimetamata Šoutjärve vepsa muuseumi rajaja Rürik Lonini kogutut, mille ta avaldas raamatus "Lühilaulud ehk tšastuškad" ja segakogumikus "Minu rahva folkloor" (Lonin 2000a; vt ka 2000b). Autoriluulet on avaldatud veel kolmes jutte ja luulet sisaldavas segakogumikus (vt allpool).

Eraldi tuleb kõnelda lastekirjandusest, kuid neile mõeldud luulekogusid on veel üsna kasinalt. Üks neist on N. Zaiceva luulekogu "Armas Liisa" (Zaiceva 2005a). Ka A. Andrejeva kogu sisaldab lasteluulet. N. Zaiceva on tõlkinud Armas Mišini ja E. Kiuru lühendatud eepose "Kalevala lastele ja noorsoole" (Kalevala 2003). L'udmila Melentjeva avaldas vepsa lastelaule nootidega (Melentjeva 1994). Lastele mõeldud luulet ja laule nootidega sisaldab ka noore vepslasest õppejõu Ol'ga Žukova hiljuti ilmunud raamatuke (Žukova 2011).

Vepsa keelde on tõlgitud eri maade luuletajate teoseid, sh Aleksandr Puškini, William Shakespeare'i, Umar Hajjami, Sergei Jessenini jt loomingut. Vepsa luulet on tõlgitud paljudesse keeltesse, teadaolevalt eesti, karjala, komi, mari, mokša, norra, prantsuse, rootsi, soome, vene, udmurdi ja ungari keelde. Eestis on ilmunud Arvo Valtoni ja Jaan Õispuu koostatud kogumik "Kuum öö", milles on muu seas esitatud 11 vepsa luuletaja vepsakeelseid värsse koos Jaan Õispuu tõlgetega ning Jaan Õispuu ja Arvo Valtoni poolt tõlgituna Nikolai Abramovi luulekogu "Kurgede aeg" (Abramov 2010b).

Siirdume nüüd proosa käsitlemisele. Selles vallas on seni ilmunud 7 vepsakeelset teost, lisaks 3 luulet ja proosat sisaldavat segakogumikku. Vepslastel oli aastani 1990 teada kolm andekat proosakirjanikku: Viktor Pulkin, Anatoli Petuhov ja Raisa Lardot (snd Larjuškina), kuid neist kaks esimest kirjutavad vene keeles, Lardot aga soome keeles (vt ka Zaiceva 2005b: 182-184). 1993. aastal Vepsa Kultuuri Seltsi korraldatud kirjandusvõistlusel tuli võitjaks Keskvepsast Pondalast pärinev Viktor Jašov vepsakeelse proosapalaga "Kondi" ('Karu'). Vepsakeelset proosakirjandust on tõlgitud teistesse keeltesse suhteliselt vähe, küllap pole see veel piisavalt küps. 
Vepsa keeles on käesolevaks ajaks ilmunud vaid üks romaan "Kalarand". Selle lõi poolenisti vepsa, poolenisti juudi päritolu noor muusik Igor Brodski Peterburist (Brodski 2002). Muide, Peterburi on Vepsamaast mõneti eraldi seisev vepsa kultuuri saar. Teost esitleti Soomes Kuhmos toimunud vepsa kirjanike esimesel konverentsil 2002. aastal, kus osales 12 vepsa keeles kirjutavat inimest. Armastusromaan "Kalarand" ei vii lugejat traditsioonilisse vepsa külaühiskonda, vaid käsitleb hoopis linnakeskkonda. Raamatut on ajakirja Keel ja Kirjandus veergudel tutvustanud Kristi Salve (2004).

Proosa- ja luulekogumik "Kodukant" oli oluline tähis vepsa noores kirjanduses (Kodirandaine 1996). Huvipakkuvaim selles on Zaiceva tõlgitud vene keeles kirjutava Vassili Pulkini teos "Laps'aigan abekirj" ('Lapsepõlve aabits'). Nimetatud kogumikus ilmus ka eespool mainitud "Kondi" ja muud külaproosat. Mullu ilmus esimene vepsa kirjanduslik almanahh "Värske tuul", milles on vepsa keeles publitseeritud nii originaalset kui ka vene keelest tõlgitud belletristikat, peale selle veel kunsti, olukirjeldusi jm (Verez 2011). Üks segakogumik sisaldab vepsa- ja karjalakeelset loomingut (Ščerbakova, Aleksejeva 2010).

Vepsakeelset kirjasõna sisaldab teiste uurali keelte hulgas kolm paljukeelset kogumikku, nimelt Sõktõvkaris ilmunud "Toomejõgi" (luule ja proosa) ning "Valged ööd" (luule; L'öm ju 2008; Belõje 2010), samuti A. Volkovi ja Armas Mišini kokkupandud "Ugrimaalt Balatonile” (Jugras 2006). Väärtuslikuks abimaterjaliks ilukirjanduskeele rikastamisel on Eesti teadlaste koostatud kaheosaline vepsa vanasõnade raamat neljas keeles vastetega (Vepsa 1992a, 1992b).

Lastele mõeldud raamatutest kuulub proosakirjanduse alla vene keelest tõlgitud Silakova "Tõelised sõbrad" ja "Valge öö" (Silakova 2006, 2009). Mõlemad on vepsandanud ajakirjanik Marina Ginijatullina. On tõlgitud ka üks koomiks "Luhtunud kalalkäik" (Lukkonen 1992). Seega pole originaalset vepsa lasteproosat veel raamatuna ilmunud. Samuti on avaldatud kolm muinasjutukogu, üks neist Lönnroti kogutud muinasjuttudest, mis on Zaiceva tõlkes üllitatud ka soome keeles, ning kaks teist sisaldavad vepsa lugu- 
sid paralleelselt vene tõlgetega (Vepsän 1996; Vepsänman 2006, Iče 2011). Lisaks väärib siinkohal mainimist Karjala Õpetajate Täiendusinstituudi poolt üllitatud väike segakogumik, mis sisaldab peale vepsakeelsete muinasjuttude veel jutustusi ja luuletusi ("Skazki" 1993). Eestlastest on vepsa muinasjutte kogunud, eestindanud ja raamatuna avaldanud Kristi Salve (Vepsa 1993).

Vepsa ilukirjandust ilmub peale raamatute ka ajakirjanduses. Üks kord kuus üllitatakse aastast 1993 neljaleheküljelist ajalehte "Kodima" ('Kodukant'). See on kakskeelne: välimised leheküljed vepsa, sisemised aga vene keeles. Ajalehe algataja ja esimene toimetaja oli Nina Zaiceva. Ajalehes avaldatakse nii ilukirjanduslikke palu kui ka olustikulisi ja päevakajalisi lugusid, nii originaale kui ka tõlkeid (vt ka Salve 1994). Vepsakeelset loomingut avaldavad ka ajakiri "Carelia" (tõsi küll, hilisemal ajal väga vähe) ja lasteajakiri "Kipinä" ('Säde'). Viimane hakkas soome- ja karjalakeelse kõrval mullu ilmuma ka vepsa keeles, nimelt neli 24-leheküljelist numbrit aastas. See on tähtis samm nii vepsa oleviku kui ka tuleviku jaoks. Peale paberile pandud vepsakeelse kirjasõna võib üht-teist leida ka internetist, nagu "Kodima” ja "Kipinä" numbreid jm.

Vepsa keelde on tõlgitud $9 \mathrm{va}$ i mulik ku teost, sh apostlite teod ja neli evangeeliumi (Apostoliden 1999; Evangelii 1993, 1996, 1998; Markan 1992). Üsna paks on värvipiltidega lastepiibel (Lapsiden 1996; vt Jegorova 1997). Kõige mahukam seni ilmunud vepsa ükskeelne raamat onUus Testament ( $\mathrm{Uz}^{\prime}$ Zavet 2006). Selle tõlkimisel oli lähteks soomekeelne Uus Testament. Asjaga tegeles peale tõlkija teoloogilise konsultandina Inka Pekkanen, kes võrdles tõlget kreekakeelse alustekstiga, ja teisi (Pekkanen 2005: 163). Peaaegu kogu vaimuliku kirjasõna on tõlkinud Nina Zaiceva, ainult "Jeesuse elu" on vahendanud Rürik Lonin (Iisusan 1991, 1994). Muide, R. Lonini tõlge on vepsakeelsete raamatute seas teise perioodi esimene pääsuke.

Suhteliselt palju on vaadeldaval ajajärgul ilmunud vepsakeelset õppekirjandust, nimelt 17 raamatut, mis on peaaegu võrreldav luuleraamatute arvuga, kuigi kogumaht tuleb õpikirjanduse kasuks. 1991. aastal ilmus Nina Zaiceva ja Maria Mulloneni koostatud raamatute raamat - kukeaabits, mis on teatavasti aluseks iga- 
sugusele kirjandusele (Zaiceva, Mullonen 1991a). Järgmisel aastal ilmus Šoutjärve keskkooli õpetajate jõupingutuste tulemusel kirillitsas koostatud vepsa aabits (Maksimova, Kottina 1992). See jäi ainukeseks taoliseks katseks.

Lahkuminevalt esimesest perioodist moodustavad vepsakeelse õpikirjanduse põhilise osa vepsa keele materjalid: kaks õpikut (Kukojeva, Ginijatullina2007, 2009), kolm lugemikku (Zaiceva, Mullonen 1991b, 1994; Kottina, Maksimov, Zaiceva 1998), neli töövihikut (Ginijatullina, Kukojeva 2008; Mel'nik 2000, Vepsän 2004; Popova, Zaiceva 2004) ning üks grammatikaharjutuste kogu (Rogozina, Zaiceva 2004). Enamik õppekirjandusest on koostatud algklasside jaoks, vaid vepsa grammatika on mõeldud 5.-9. klassi õpilastele (Zaiceva 2003). J. Kočerina raamat, mis kujutab endast piltsõnastikku grammatika algetega, on mõeldud lastele, kes alles alustavad vepsa keele õppimist (Kočerina 2004). Osa õppevahendeid sobib üliõpilastele, nagu Zaiceva koostatud kaks morfoloogia-alast tööd (Zaiceva 1995, 2000a). Igor Brodski on avaldanud lastele värvitrükis põneva loodusloo lugemiku (Brodski 2000).

Seni on ilmunud 9 nimetust teat mekirjandust. Nende hulgas on 7 kaks- või mitmekeelset sõnastikku, sh 20-leheküljeline keeleteaduse terminite sõnastik, koolisõnastik ning vepsa-vene ja vene-vepsa sõnaraamatud (Brodski 2005; Lingvistine 2001; Školvaihišt 2001; Zaiceva, Mullonen 1995, 2009, 2010; Vepsän 2004). Huvi võiks pakkuda karjala, vepsa ja saami murrete kõrvutav sõnaraamat (Sopostovitel'no 2007). Ilmavalgust nägi ka esimene, N. Zaiceva ja O. Žukova koostatud kakskeelne vene-vepsa vestmik (Venä-vepsläine 2009). Suhteliselt piiratud arvul sisaldab vepsakeelses vestluses kasutatavaid lauseid juba varem Eestis ilmunud 19-keelne "Uurali keelte sõnastik" (2004, 2011).

Vepsa keeles ilmus 2008. aastal esimene pääsuke ka teabek i r jandusest, nimelt üsna paks, 250-leheküljeline, kuid väikeses formaadis "Vepslased", mis annab ülevaate keelest, elupaikadest, ajaloost, usundist ning vaimsest ja materiaalsest kultuurist (Strogalščikova2008). Selle autor on vepslasest Petroskoi teadur Zinaida Strogalščikova. A i me - ja samaaegselt kunstikirja nduse hulka võib paigutada Soomes ilmunud fotoalbumi Vepsamaast, mis sisal- 
dab ka lühikest ajaloo ülevaadet (Savolainen 1998). Vähese vepsakeelse tarbekirjanduse hulka kuuluvad O. Žukova tõlgitud inimõiguste deklaratsioon ja suureformaadiline värvitrükis üllitatud 2009.-2010. aasta kalender (Mehen 2009; Vepsläine 2009).

\section{Kokkuvõtteks vepsakeelsete raamatute kohta}

Vepsakeelse kirjanduse eelperioodil (1853-1931) ilmus ühtekokku kuus vepsakeelset teksti sisaldavat teost (5 Soomes ja 1 Venemaal). Neist kolme saab pidada vepsa raamatuks, millest üks kuulus teatmekirjanduse, kaks teaduskirjanduse valda. Vepsa kirjanduse esimesel perioodil (1932-1937) nägi päevavalgust 32 vepsakeelset raamatut (31 Venemaal ja 1 Soomes). Neist enamiku (28) moodustas õppekirjandus, ülejäänud kolm raamatut esindasid teadus-, teatme- ja tarbekirjandust. Aastas avaldati keskmiselt 4,6 raamatut. Vaheperioodil (1938-1988) avaldati nii Soomes kui ka Venemaal üpris vähe, nimelt kummaski kaks teadusraamatut.

Teisel perio odil (alates 1989. aastast) on peaaegu veerandsajandi jooksul avaldatud 66 vepsakeelset raamatut. Neist 27 kuuluvad ilu-, 17 õpi-, 9 vaimuliku, 9 teatme-, 2 tarbe-, 1 teabe- ja 1 aimekirjanduse valda. Ilukirjandusteostest 17 on pühendatud luulele, 7 proosale ja 3 on segakogumikku. Aastas on trükitud 1-8 raamatut, v.a 1997. aastal, mil ei ilmunud ühtki teost. Keskmiselt tuleb aasta kohta kolm vepsakeelset raamatut. Seega on vepsa kirjandus täiesti olemas ja muutub üha mitmekesisemaks. Erinevalt esimesest ajajärgust osutati teisel perioodil peale kooliliteratuuri suuremat tähelepanu ilu- ja vaimulikule kirjandusele. Praegu puudub teadaolevalt veel teaduskirjandus. Luule- ja muinasjutukogud ilmuvad sageli paralleelselt vepsa ja mõnes teises, sagedamini vene keeles. Võrreldes esimese perioodi omadega on tänapäeva vepsa raamatud välimuselt kenad. Nende tiraaž on üsna erinev, nt lastepiiblit trükiti 5000 eksemplari, luulekogusid aga tavaliselt 500-1000. Kirjanduse väljaandmisel on abi osutanud Karjala Vabariik, Soomes Kuhmos tegutsev Juminkeko-fond, Castréni Selts jt. 
NSV Liidu kui impeeriumi lagunemine võimaldas veel üsna hilja, nimelt XX sajandi lõpul Venemaa väikerahvaste ärkamise ja endamärkamise, oma keele ja kultuuri arendamise ning tulevikulootuste hellitamise. Kuigi vepslaste arv drastiliselt kahaneb, ei ilmne kirjanduses veel raugemise märke, pigem vastupidi. Suurt rõhku pannakse lastekirjandusele. See on eriti positiivne. Kui kaua kirjanduse üsna hoogne areng kestab? Seda ei tea kindlalt paraku keegi. Mulle tundub, et käes on vepsa kirjanduse sügis, ja see on kuldne.

\section{Internetiallikad}

Бродский, И. В. Vepsänkel'židen kirjoiden bibliografii = Books in Vepsian - bibliography = Библиография книг на вепсском языкепо состоянию на 1.10.2007 г.

Internetis: http://www.oocities.org/meidenkodima/bibliografii.htm (vaadatud märts 2012).

Joalaid, Marje. Vepslastest ja vepsa keelest. - Fenno-Ugria Asutus.

Internetis: http://www.fennougria.ee/index.php?id=19761 (vaadatud märts 2012).

Национальная библиотека Республики Карелия.

Internetis: http://library.karelia.ru/cgi-bin/library/ecatalog.cgi (vaadatud märts 2012).

\section{Kirjandus}

Abramov, Nikolai 1994. Koumekümne koume: Runokirj. Redaktor Nina Zaiceva. Känzi Irina Kart. Petroskoi: Karjala. - 54 lp.

Abramov, Nikolai 1999. Kurgiden aig: Runod . Redaktor N. Zaiceva. Petroskoi: Periodika. - 64 lp.

Abramov, Nikolai 2005. Pagiškam, vel'l' $l^{\prime}$ Поговорим, брат: Сборник стихов. Petroskoi: Periodika. - $112 \mathrm{lp}$. 
Abramov, Nikolai 2010a. Kahtisti koumnekümne koume: runokogomuz vepsän $i$ vengrian kelil = Kétszer harminchárom: Válogatott versek vepsze és magyar nyelven. Válogatta és fordította Nagy Katalin. Budapest: Pyteas. - 172 p.

*Abramov, Nikolai 2010b. Kurgede aeg. Tlk. Jaan Õispuu, Arvo Valton. Toim. Arvo Valton. Tallinn: Kirjastuskeskus. $-64 \mathrm{lk}$.

Abramov, Nikolai 2011. Les chants des forêts: Edition bilingue. Poèmes choisis, traduits du vepse et présentés par Sébastien Cagnoli. (Poésies ouraliennes; 4) Paris: Adéfo. -74 p.

*Ahlqvist, August 1859. Anteckningar i Nord-Tschudiskan. (Acta Societatis Scientiae Fennicae; 6.) Helsingfors. -64 lp.

*Ahlqvist, August 1869. Suomalainen murteiskirja tahi lukemisia Viron, Karjalan, Vatjan, Vepsän ja Liivin kielillä suomalaisten sanastojen kanssa. Helsinki. $-8,274 \mathrm{~s}$.

Andrejev, F. A. 1934a. Literaturnij hrestomatij vepskijale nacal'nijale şkolale: Kuumanz' openduz voz'. Leningrad: Kirja. - 82 lp.

Andrejev, F. A. 1934b. Vepskijan grammatikan openduzkirj ez'maizele i toizele klassale vepskijas nacal'nijas şkolas. Leningrad: Kirja. - 49 lp.

Andrejev, F. A. 1935. Literaturnij hrestomatij vepskijale nacal'nijale şkolale: Nel'l'andele openduz vodele. 2 cast'. Leningrad: Kirja. - 93 lp.

Andrejev, F. A. 1937. Lugend knig: Kuumandele klassale nacal'nijale şkolale. Cast' 3. - Leningrad, Moskva: Gosudarstvennij openduz-pedagogiceskij izdatel'stv. - 124 lp.

Andrejev, F. A., N. I.Bogdanov, V. I.Petuhov, I. A. Silin 1933. Lugend knig toizele openduz vodele vepsoiden nacalnijas şkolas. Redaktor F. Andrejev. Leningrad: Kirja. - 88 lp. Internetis: http://fulr.karelia.ru/cgi-bin/flib/veps_book1.cgi (vaadatud märts 2012).

Andrejev, F., M. Hämäläinen 1936. Bukvar' vepsän şkolile. Moskva, Leningrad: Gosudarstvennij openduz-pedagogiceskij izdatel'stv. - 67 lp.

Internetis: http://fulr.karelia.ru/cgi-bin/flib/bukvar.cgi (vaadatud märts 2012).

Andrejeva, Alevtina 2003. Koivuine: Runod. Kuhmo: Juminkeko, Petroskoi: Periodika.- 127, [1] lp.

Andrejeva, I. F. 1936. Lugend knig: Ez'maizele klassale. Cast' 1. Moskva, Leningrad: Gosudarstvennıj openduz-pedagogiceskij izdatel'stv. - 105 lp. 
Apostoliden 1999 = Apostoliden tegod . Stokgol'm, Helsinki: Biblijan Kändmižen Institut, 1999. - $104 \mathrm{lp}$.

${ }^{\star}$ Ariste, Paul 1964. Vepsa muinasjutte: (Äänis- ja keskvepsa keelenäiteid). Töid läänemeresoome ja volga keelte alalt. Toimetaja: E. Pajusalu-Adler. Tallinn, lk 5-23.

Bašnin, Mihail 2003. Vanh zirkul = Старое зеркало: Стихи на вепсском и русском языках. Petroskoi, Periodika. - 63, [1] lp.

${ }^{*}$ Belõje $2010=$ Белье ночи $=$ Еджыд войяс $=$ Мӧдьь уйёс = Ош йюд влак

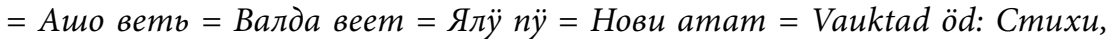
paccказы. Составитель Н. А. Обрезкова. Сыктывкар: Филиал ГРДНТ Финно-угорский культурный центр Российской Федерации. - 188, [2] с.

Bogdanov, N., M. Hämäläinen, A. Mihkijev 1932. Ez'mäine vepsiden azbuk $i$ lugendknig. Leningrad: Kirja. - $78 \mathrm{lp}$.

Internetis: http://fulr.karelia.ru/cgi-bin/flib/azbuka.cgi (vaadatud märts 2012).

Bogdanov, N., M. Loginov, G. Bol'şakov, V. Romanov, I. Andrejva, M. Sokolov. Lugend knig: Toizele klassale nacal'nijale şkolale. Cast' 2. Moskva, Leningrad: Gosudarstvennij openduz-pedagogiceskij izdatel'stv, 1936. - 124 lp.

Internetis: http://fulr.karelia.ru/cgi-bin/flib/veps_book2.cgi (vaadatud märts 2012).

Brodski, Igor 2000. Ičemoi londuz: Lugendkirj lapsile vepsän kelel. Toimitai: N. Zaiceva. Petroskoi: Periodika. - 103 lp.

Brodski, Igor 2002. Kalarand: Roman. (Juminkegon painduzed; 25) Kuhmo, Petroskoi: Juminkeko, Verso. - 146, [1] lp.

Brodski 2005 = Бродский И. В. Вепсско-русский, русско-вепсский словарь. Санкт-Петербург: Просвещение. - 256 с.

Evangelii 1993 = Evangelii Joannan mödhe. Stokgol'm, Helsinki, Biblijan Kändmižen Institut, 1993. - 86, [6] lp.

Evangelii 1996 = Evangelii Lukan mödhe. Stokgol'm, Helsinki: Biblijan Kändmižen Institut, 1996. - 94 lp.

Evangelii 1998 = Evangelii Matvejan mödhe. Stokgol'm, Helsinki: Biblijan Kändmižen Institut, 1998. - 97, [1] lp.

Ginijatullina, Marina, Nadežda Kukojeva 2008. Radlehtik: Vepsän kel' 1. Petroskoi. - 39, [1] lp. 
Grigor'jev, N. 1937. Pol'toşt' paginad: Dispetceran sanutez. Vepsän kelele perevodi M. Loginov. Moskva, Leningrad: Lapsiden literaturan izdatel'stv. - 38 lp.

Hämäläinen, M., F. Andrejev 1934. Vepskijan kelen grammatik. Leningrad: Kirja. -55 lp.

Hämäläinen, M., F. Andrejev 1935. Vepsän kelen grammatik kuumandele $i$ nel'l'andele klassale nacal'nijas şkolas. Leningrad: Kirja. - 61 lp.

Hämäläinen, M. M., F. A. Andrejev 1936. Vepsa-venähine vajehnik. Moskva, Leningrad: Gosudarstvennij openduz-pedagogiceskij izdatel'stv. - 75 lp.

Internetis: http://fulr.karelia.ru/cgi-bin/flib/slovar.cgi (vaadatud märts 2012).

Iče 2011 = Iče kulin, iče nägin: Vepsläižed sarnad = Сам слымал, сам видел: Вепсские сказки. Составила: О. Жукова. Petroskoi: Verso, 2011. - 43, [1] lp.

Iisusan 1991 = Iisusan elo. Stokgol'm, Helsinki: Biblijan Kändmižen Institut, 1991. - 61, [1] lp.

Iisusan 1994 = Iisusan elo. 2., kohetud painuz. Stokgol'm, Helsinki: Biblijan Kändmižen Institut, 1994. - 61, [1] lp.

*Inno, Helvi 1991. Ensimmäisen vepsäläisen sanakirjan laatija. - Carelia, n-ro 8, s. 112-118.

*Jegorova, Svetlana 1997. Lasten raamattu - askel kohti kirjakieltä. - Carelia, n-ro 1, s. 120-121.

Jugras 2006 = Jugrasta Balatonille: suomalais-ugrilaista runoutta karjalan, suomen ja vepsän kielillä. Jugras Balatonah sah: suomelas-ugrilazii runoloi karjalan, suomen da vepsän kielil. Составители: А. Л. Волков и А. И. Мишин. Petroskoi: Periodika, 2006. - 221, [3] s.

Kalevala 2003 = Kalevala: A. Mišinan i E. Kiurun kompozician mödhe. Vepsäks om kändnu N. Zaiceva. Kuhmo, Petroskoi: Juminkeko, Periodika, 2003. - 164 lp.

Kettunen, Lauri 1920. Näytteitä etelävepsästä 1. (Suomi; 4: 18.) Helsinki: Suomalaisen Kirjallisuuden Seura. - 126 s.

Kettunen, Lauri 1925. Näytteitä etelävepsästä 2. (Suomi; 5: 4) Helsinki: Suomalaisen Kirjallisuuden Seura. - 146 s.

Kipinä: Vepsläine kibin: [Laps'kulehtez]. Petroskoi: Periodika, 2011, n 1, 6, sügüz'ku, tal'vku. 
Internetis: http://kipina.rkperiodika.ru/arhiv.php?year=0000 (vaadatud märts 2012).

Kočerina, J. J. 2004. Opendam vepsän kel't: Openduzozuteline abukirj lapsile, alaopenikoile i kazvatajile = Учимся говорить по-вепски. Petroskoi: Periodika. - 194, [1] lp.

Kodima: [Lehtez]. Petroskoi: Periodika, 1992-2011, 225 nomerad. Internetis: http://kodima.rkperiodika.ru/index.php?option=com_arhive\&view $=$ arhive\&id (vaadatud märts 2012).

Kodima, Vepsänma. Toimitai: Markku Nieminen. (Juminkegon paindused; 32.) Kuhmo, Petroskoi: Juminkeko, Karelija, 2003. - 69, [3] lp.

Kodirandaine 1996 = Kodirandaine. Runod i sanutesed vepsän kelel. Petroskoi, Karjala, 1996. - 125, [1] lp.

Kottina, A., A. Maksimov, N. Zaiceva 1998. Meiden sana: Lugendkirj augotižškolan täht. Petroskoi: Periodika. - 96 lp.

Kukojeva, N. A., M. В. Ginijatullina 2007 = Кукоева, Н. А. Vepsän kel' 1: Учебник для 1 класса общеобразовательных учреждений. Петрозаводск: Периодика, 2007. - 39, [1] с.

Kukojeva N. A., M. B. Ginijatullina 2009. Vepsän kel': 2. klass. Petroskoi: Periodika. - 69, [2] lp.

Lapsiden 1996 = Lapsiden Biblii: Biblijan sanutesed kuvidenke. Tegijad: Borislav Agapovič i Vera Mattelmäki. Vepsäks om kändnu Nina Zaiceva. Stokgol'm, Helsinki: Biblijan Kändmižen Institut, 1996. - 542 lp.

${ }^{*}$ Kuum öö: Soome-ugri rahvaste tänapäeva luulet $=$ Palavu $\ddot{u} о \ddot{~}=$ Kuuma yö = Пӧсь вой $=$ Пьм оц $=$ Пӧсь уй =Шокшо йуд = Пфи ве =Пфи илядь = Hиl $\ddot{о}=$ Ядембада пи. Koost. ja tlk. Arvo Valton, Jaan Õispuu. Toim. Nadja Pchelovodova. Tallinn: Kirjastuskeskus, 2006. 777, [5] lk.

Lardot, R. M. 2001. Däižed lindud lanktoba oksilpei = Jäätyneet linnut putoavat oksiltaan. Kääntäneet Maria Zaiceva, Miikul Pahomov, Leo Maltšukov. Jyväskylä: Atena. - 96 lp.

Lingvistine termišt = Лингвистическая терминология на вепсском языке. Petroskoi: Periodika, 2001. - 19, [1] lp.

Lonin, R[ürik]. 2000a. Minun rahvhan fol'klor. Petroskoi: Periodika. - 108 lp.

Lonin, R[ürik]. 2000b. Lühüdad pajoižed. Om keradanu R. Lonin. Muzik: Irina Semakova. Petroskoi, 2000. - $70 \mathrm{lp}$. 
Lukkonen, Vladimir 1992. Ozatoi kalatez: [Komiks]. Perevodiba vepsän kelele N. Zaiceva. Petroskoi: Karjala. - 14 lp.

${ }^{*} L^{\prime} \ddot{о т j и ~} 2008=$ Льӧм ю = Льӧмпуа юок = Ломбо эн'ер = [?] Zelnicemeggyespatakoska $=$ Льöмny uyp $=$ Toomingajõgi $=$ Tuomijoki $=$ Tom' jogi :

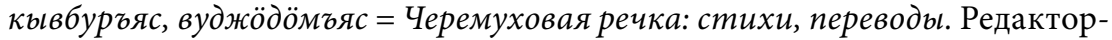
составитель: Е. В. Козлова. Перевод: В. В. Тимин и др. - Сыктывкар: Кола, 2008. - 254, [1] c.

*Lönnrot, Elias 1853. Om det Nord-Tschudiska språket: Akademisk Afhandling. Helsingfors. $-54 \mathrm{~s}$.

${ }^{\star}$ Lönnrot, Elias 1991. Om det Nord-tschudiska språket. - Valitut teokset 3: Kirjoitelmia ja lausumia.Suomalaisen Kirjallisuuden Seuran toimituksia 551. Helsinki-Pieksamäki, s. 41-74.

${ }^{*}$ Lönnrot, Elias 2002. Om det Nord-tschudiska språket: Elias Lönnrotin väitöskirja vepsän kielestä vuodelta 1853. (Juminkeon julkaisuja; 24) [Kuhmo:] Juminkeko, 2002. - 53 s.

Maksimova, Kottina 1992 = Максимова Р. Ф., Э. В. Коттина. Букварь: Для 1 класса вепсских школ. Санкт-Петербург: Просвещение. - 127 с.

Markan 1992= Markan Evangelii. Stokgol'm, Helsinki: Biblijan Kändmižen Institut. 1992. - 83, [2] lp.

Mehen = Mehen oiktuziden ühthine deklaracii: Om todištadud i ezitadud Päassamblejan rezolucijal 217 A (III) 10. tal'vkud v. 1948. Перевод: Ольга Жукова. Москва: Права человека, 2009. $12 \mathrm{lp}$.

Mel'nik, E. L. 2000. Ümbrišt: Tölehtik augotižškolan openikoile= Окружающая среда: Рабочая тетрадь для начальных школ. (Моя Карелия) Petroskoi: KGPU. - 48 lp.

Melentjeva, L. 1994. Soitoine: Vepsän randan lapsiden pajod. Vepsän kelen redaktor: Nina Zaiceva. Muzikan redaktor Irina Semakova. Petroskoi, Karjala. $-45 \mathrm{lp}$.

${ }^{*}$ Mišin, Armas 2005. Vepsäläinen kirjallisuus ammattikirjailijan silmin. Vepsä: Maa, kansa, kulttuuri. Toimittanut Lassi Saressalo. Tampere, Helsinki: Tampereen museot, Suomalaisen Kirjallisuuden Seura, s. 193-210.

*Mošnikov, Oleg 2007. “Jäätyneet linnut”. - Carelia, n-ro 9, s. 118-120. 
*Mullonen 1967 = Муллонен, М. Вепсская письменность. - Прибалтийскофинское языкознание: Вопросы фонетики, грамматики и тексикологии. Ленинград: Наука, с. 195-109.

Näytteitä vepsän murteista. Keränneet ja julkaisseet Lauri Kettunen ja Paavo Siro. Suomalais-Ugrilaisen Seuran toimituksia 70. Helsinki: Suomalais-Ugrilainen Seura, 1935. - $193 \mathrm{~s}$.

Näytteitä äänis- ja keskivepsän murteista. Keränneet E. N. Setälä ja J. H. Kala. Julkaissut ja suomentanut E. A. Tunkelo. Suomalais-Ugrilaisen Seuran toimituksia 100. Helsinki: Suomalais-Ugrilainen Seura, 1951. - 621, [1] s.

*Pekkanen, Inka 2005. Raamattua vepsäksi. - Vepsä: Maa, kansa, kulttuuri. Toimittanut Lassi Saressalo. Tampere, Helsinki: Tampereen museot, Suomalaisen Kirjallisuuden Seura, s. 163-170.

Popova, N. S. 1933a. Arifmetikan openduzkirj nacal'nijale şkolale: Ez'mäine $v o z^{\prime}$ opendust. Cast' 1 . Venäkelelpei perevodi N. I. Bogdanov. Leningrad: Kirja. $-70 \mathrm{lp}$.

Popova, N. S 1933b. Arifmetikan openduzkirj nacal'nijale şkolale: 2. voz' opendust. Leningrad: Kirja. -73 lp.

Popova, N. S. 1934a. Arifmeticeskijoiden zadacuiden i har'goitusiden keraduzkirj: Kuumandele openduz'vodele nacal'nijale şkolale. Cast' 1. Leningrad: Kirja. $-58 \mathrm{lp}$.

Popova, N. S. 1934b. Arifmeticekijoiden zadacuicen i har'goidusiden keraduzkirj: 4 openduzvoz' nacal'nijale şkolale. Cast' 2. Leningrad: Kirja. - 69 lp.

Popova, N. S. 1934c. Arifmetikan openduzkirj: 2 openduzvoz'. Leningrad: Kirja. $-74 \mathrm{lp}$.

Popova, N. S. 1934d. Arifmetikan openduzkirj: Nacal'nijale şkolale: 3-le i 4-le openduzvozile. 3. cast'. Leningrad: Kirja. - 69 lp.

Popova, N. S. 1936. Arifmetikan openduz knig ez'mäizele klassale nacal'nijale şkolale. Cast' 1. Moskva, Leningrad: Gosudarstvennıj openduz-pedagogiceskij izdatel'stv. -64 lp.

Popova, N. S. 1937a. Arifmeticeskijoiden zadacuiden i har'goidusiden keraduz knig: 3-le klassale nacal'nijan şkolan. Cast' 1 . Vepsän kelele perevodi M. Loginov. Leningrad, Moskva, Gosudarstvennij openduz-pedagogiceskij izdatel'stv. -49 lp. 
Popova, N. S. 1937b. Arifmetikan openduz knig: Toizele klassale nacal'nijale şkolale. Cast' 2. Perevodi N. I. Bogdanov. Leningrad, Moskva: Gosudarstvennij openduz-pedagogiceskij izdatel'stv. - $69 \mathrm{lp}$.

Popova, N. S. 1937c. Arifmetikan openduz knig nacal'nijale şkolale: 3-le i 4-le klassoile. Cast' 3. Perevodi V. M. Romanov. Leningrad, Moskva: Gosudarstvennij openduz-pedagogiceskij izdatel'stv. - 57 lp.

Popova, V., N. Zaiceva 2004. Petroskoi. - 136 lp.

Programmad 1937 = Programmad vepsän nacal'nijale şkolale: Coma-kirjutez. Leningrad, Moskva: Gosudarstvennij openduz-pedagogiceskij izdatel'stv, 1937. -28 lp.

*Prozes, Jaak 2012. Rahvaloendus ja soome-ugri. - Sirp, 23. III.

Rogozina, V., N. Zaiceva 2004. Vepsan kelen harjoituzkogomuz: Fonetik. Nimiformad. Adverbat. Abusanad. Petroskoi: Petroskoin valdkundan korgedškol. $136 \mathrm{lp}$.

*Salve, Kristi 1994. Vepslaste “Kodima”. - Keel ja Kirjandus, nr 5, lk 319-320.

*Salve, Kristi 2004. "Kalarand": Vaatlusi ja võrdlusi: [Retsensioon]. - Keel ja Kirjandus, nr 4, lk 306-309.

${ }^{\star}$ Savolainen, Mikko 1998. Vepsä: Vepsänmaa $=$ Vepsian land $=$ Vepsänma $=$ Vepslandia. Historiateksti: Kaija Heikkinen, Aleksandr Saksa. Käännökset: Nina Zaiceva, Markku Tuomi, Aleksandr Saksa. Oulu: Atena. - 142 s.

Silakova, Natalia. Todesižed sebranikad.Vepsäks kändi Marina Ginijatullina. Petroskoi: Periodika, 2006. 31, [1]lp.

Silakova, N[atalia]. 2009. Vauged ö. Vepsäks kändi Marina Ginijatullina. Petroskoi : [s. n.], 2009. - 31, [1] lp.

Skazki 1993 = Сказки, рассказы, пословицы и стихи на вепсском языке. Сборник. Составитель: Л. Ф. Алексеева. Петрозаводск: Карельский институт усовершенствования учителей. - $34 \mathrm{c}$.

Sopostovitel'no 2007 = Сопоставительно-ономасиологический словарь диалектов карельского, вепсского и саамского языков. Под общей редакцией Ю. С. Елисеева и Н. Г. Зайцевой. Составители: А. П. Баранцев и др. Петрозаводск: Карельский научный центр РАН, 2007. - 343 с.

*Spiridonova 2000 = Спиридонова, И. А. Вепсская литература: Проблемы становления. - История литературы Карелии 3. Петрозаводск: Карельский научный цнетр РАН, с. 391-419. 
Strogalščikova, Zinaida 2008.Vepsläižed: Istorii-etnografine tedosanutez. Kändai: Nina Zaiceva. Toimitajad: Jelizaveta Haritonova, Olga Žukova. (Bibliotheca fenno-ugrica.) Petroskoi: Periodika. - 252 lp.

Ščerbakova, Tamara, L'udmila Aleksejeva 2010. An'oile da Ven'oile vunukkazil armahil = An'oile da Ven'oile armhile vonukoile. Петрозаводск: Verso. - 93, [1] lp.

Školvaihišt = Школьная пексика на вепсском языке. Составитель: Е. Харитонова. Petroskoi: Periodika, 2001. - 55, [1] lp.

*Zaiceva 1981 = Зайцева, М. И. Грамматика вепсского языка: (Фонетика и морфология). Ленинград: Наука. - 360 с.

*Zaiceva, Nina 1989. Kieli on säilytettävä. - Punalippu, n-ro 2, s. 129-132.

Zaiceva, N[ina] 1995. Vepsän kelen grammatik: (1. Nimiden kändluz). Petroskoi. -114 lp.

*Zaiceva 1997 = Zaitseva, Nina. Vepsä taistelee olemassaolostaan. - Carelia, n-ro 1, s. 116-119.

Zaiceva N[ina] 2000a, vt Zaikov jt 2000.

*Zaiceva 2000b = Зайцева, Н. Г. Вепсская литература 1990-х годов. История литературы Карелии 3. Петрозаводск: Карельский научный цнетр РАН, с. 391-419.

Zaiceva, N[ina]. 2003. Vepsän kelen grammatik: Teoretine openduzkirj 5-9 klassoile. Petroskoi: Periodika. - $240 \mathrm{lp}$.

Zaiceva, Nina 2005a. Izo Lizoi. Petroskoi: Periodika. - 32 lp.

*Zaiceva, Nina 2005b. Vepsäläinen kirjallisuus tiensä alussa. - Vepsä: Maa, kansa, kulttuuri. Toimittanut Lassi Saressalo. Tampere, Helsinki: Tampereen museot, Suomalaisen Kirjallisuuden Seura, s. 181-192.

Zaiceva, Nina 2008. Vauktan unen süles. Петрозаводск: Периодика. - 90, [2] lp.

Zaiceva, Mullonen 1969 = Зайцева, М., М. Муллонен. Образцы вепсской речи. Ленинград: Наука, 1969. - 296 с.

Zaiceva, Mullonen 1972 = Зайцева, М. И., М. И. Муллонен. Словарь вепсского языка. Ленинград: Наука, 1972. - 745 с.

Zaiceva, N., M. Mullonen 1991a. Abekirj. Petroskoi: Karjala. - 94 lp. 
Zaiceva, N., M. Mullonen 1991b. Lugem i pagižem vepsäks: Lugendkirj toižele klassale. Petroskoi: Karjala. - 103 lp.

Zaiceva, N., M. Mullonen 1994. Ičemoi lugemišt: Vepsän kelen lugendkirj 3.-4. klassale. Petroskoi: Karjala. - 126, [2] lp.

Zaiceva, N., M. Mullonen 1995. Vepsä-venälaine, venä-vepsläine vajehnik: läz 14000 sanad= Вепсско-русский, русско-вепский учебный словарь: около 14000 слова. Petroskoi: Karjala. - 190, [2] lp.

Zaiceva, Mullonen 2009 = Зайцева, Н. Г., М. И. Муллонен Новый руссковепсский словарь $=U z^{\prime}$ venä-vepsläine vajehnik. Петрозаводск: Периодика. $-516,[3]$ c.

Zaiceva, Mullonen 2010 = Зайцева, Н. Г. Новый вепсско-русский словарь = $U z^{\prime}$ vepsä-venalaine vajehnik. Петрозаводск: Периодика. - 509, [1] с.

Zaikov, P., L. Rugojeva, O. Gorškova 2000. Harjotuksie vienankarjalaksi: (Verbi. Infinitiivit. Patisiipit. Partikkelit). Zaiceva N. 2000. Vepsän kelen grammatik: (2. Verboiden kändluz. Verboiden nimiformad. Kändamatomad sanad). Петрозаводск: Петрозаводский государственный университет. - 230, [2] lp. [Vepsän kelel: lp. 113-230].

Žukova, Ol'ga 2011. Mäthudel: runod da pajoižed lapsile. Petroskoi: Periodika. -15 , [1] lp.

Terehova, L. G., V. G. Erdeli 1934. Geografijan openduzkirj nacal'nijale şkolale: Kuumanz' openduz voz'. Cast' 1 . Leningrad: Kirja. - 75 lp.

Terehova, L. G., V. G. Erdeli 1936a. Geografij:Openduz knig kuumandele klassale nacal'nijas şkolas. Cast' 1 . Perevodiba I. F. Andrejeva, N. I. Bogdanov, M. G. Loginov, V. M. Romanov. Moskva, Leningrad: Gosudarstvennij openduz-pedagogiceskij izdatel'stv. - $128 \mathrm{lp}$.

Terehova, L. G., V. G. Erdeli 1936b. Geografij: Openduz knig nel'l'andele klassale nacal'nijas şkolas. Cast' 2. Perevodiba vepsän kelele F. Andrejev, N. Bogdanov, M. Loginov, V. Romanov. Moskva, Leningrad: Gosudarstvennij openduz-pedagogiceskij izdatel'stv, 1936. - 135 lp.

Tetyrev, V. A. 1934. Jestesvoznanijan openduzkirj nacal'nijale şkolale: 3 voz' opendust. Cast' 1 . Leningrad: Kirja. - 76 lp.

Tetyrev, V. A. 1935. Jestestvoznanijan openduzkirj nacal'nijale şkolale: 4 openduz voz'. Cast' 2. Leningrad: Kirja. - $115 \mathrm{lp}$. 
Tetyrev, V. A. 1937a. Jestestvoznanij: Openduz knig nacal'nijan şkolan kuumandele klassale. Cast' 1. Vepsän kelele perevodi I. Andrejeva. Leningrad, Moskva: Gosudarstvennij openduz-pedagogiceskij izdatel'stv, 1937. - 112 lp.

Tetyrev, V. A. 1937b. Jestestvoznanij: Openduz knig nacal'nijan şkolan 4-le klassale. Cast' 2. Perevodiba I. Andreeva, N. Bogdanov i V. Romanov. Leningrad, Moskva: Gosudarstvennij openduz-pedagogiceskij izdatel'stv, 1937. - 132 lp.

Uspenski 1913 = Успенский Л. Русско-иудский словарь с некоторыми грамматическими указаниями. Санкт-Петербург. - 43 с.

Internetis: http://fulr.karelia.ru/cgi-bin/flib/chudoslovar.cgi (vaadatud märts 2012).

$U z^{\prime}$ Zavet. Stokgol'm, Helsinki: Biblijan Kändmižen Institut, 2006. - 614 lp.

${ }^{*}$ Uurali keelte sõnastik: Eesti, lìvõkēl, võro, vad'd'a, ižora, suomi, karjala, vepsä, sámegiella, эрзянь, мокщень, олык мари, курык мари, коит, удмурт, ханты, матньси, таgуат, ненецяя. Koost. Valt Ernštreit jt. Toim. Eva Saar. Tallinn: SURI, 2004. - 139, [5] lk.

${ }^{*}$ Uurali keelte sõnastik: Eesti, vad'd'a, võro, lìvõ, ižora, suomi, karjala, vepsä, sámegiella, эрзянь, мокшень, олык марла, курык марла, коми, удмурт, ханты, ма̄ньси, magyar, ненеия.2., parandatud ja täiendatud trükk. Koost. Natalja Abrosimova jt. Toim. Eva Saar. Tallinn: Fenno-Ugria Asutus, 2011. 143, [1] lk.

Venä-vepsläine abupaginkirj $2009=$ Русско-вепсский разговорник. Составители: Н. Г. Зайцева, О. Ю. Жукова. Под общей редакцией Н. Г. Зайцевой. Петрозаводск: Периодика, 2009. - 222, [2]c.

*Vepsa $1992 a$ = Vepsa vanasõnad: Eesti, vadja, liivi, karjala ja vene vastetega. 1. osa. Koost. Vaina Mälk, Anne Hussar, Aime Kährik, Tiit-Rein Viitso. Toim. Arvo Krikman, Aime Kährik, Vaina Mälk, Tiit-Rein Viitso. Tallinn: Eesti Teaduste Akadeemia, 1992. - $352 \mathrm{lk}$.

${ }^{*}$ Vepsa $1992 b$ = Vepsa vanasõnad: Eesti, vadja, liivi, karjala ja vene vastetega. 2. osa. Koost. Vaina Mälk, Anne Hussar, Aime Kährik, Tiit-Rein Viitso. Toim. Arvo Krikman, Aime Kährik, Vaina Mälk, Tiit-Rein Viitso. Tallinn: Eesti Teaduste Akadeemia, 1992. - lk 353-681.

Vepsa $1993={ }^{*}$ Vepsa muinasjutte. Kogunud ja raamatuks seadnud Kristi Salve. Tallinn: Perioodika, 1993. - 78, [1] lk.

Vepsläine 2006 = Vepsläine kalendar' $=$ Вепсский календарь: 2009-2010. Составители: Ю. Наумова и др. Петрозаводск, 2009. - 24 с. 
Vepsän 2004 = Vepsän kelen radlehtik: 2. voz: К букварю Н. Г. Зайцевой и М. М. Муллонен “Abekirj”. Составила: Е. Е. Кочерина. Petroskoi, 2004. - 44 lp.

Vepsän kelen uz' vaihišt. Составили М. Б. Гиниятуллина, Е. Е. Харитонова, Н. Г. Зайцева, М. И. Муллонен. Бюллютень термино-орфографической комиссии 9. Petroskoi: Periodika, 2004. - 189, [3] lp.

Vepsän 1996 = Vepsän rahvhan sarnad. Составители: Н. Ф. Онегина, М. И. Зайцева. (Памятники фольклора Карелии.) Petroskoi: Karjala, 1996. - 261 lp.

Vepsänman 2006 = Vepsänman sarnad. Kerazi vepsläižidenno oldes vodel 1842 Elias Lönnrot. Toimitai: Nina Zaiceva. [Kuhmo], Petroskoi: Juminkeko, Verso, 2006. - 39, [1] lp.

Verez tullei: Vauktan Vesin runosanad. Составитель: Н. Г. Зайцева. Petroskoi: Periodika, 2006. - 110 lp.

Verez tullei 2011: Al'manah. Toimitajad: Larissa Cirkova jt. Petroskoi: Periodika, 2011. - 160 lp.

*Virtaranta, Pertti 1967. Lähisukukielten lukemisto. (Suomalaisen Kirjallisuuden Seuran toimituksia; 280) Helsinki: Suomalaisen Kirjallisuuden Seura.

*Õispuu, Jaan 2003. Karjala kirjandus ja keelepoliitika. - Keel ja Kirjandus, nr 7, lk 509-530.

Ä̈nisvepsän näytteitä. Keränneet ja julkaisseet A. Sovijärvi ja R. Peltola. (Suomalais-Ugrilaisen Seuran toimituksia; 171.) Helsinki: Suomalais-Ugrilainen Seura, 1982. - 7, 171, [1] s.

\section{Summary}

\section{On literature in Vepsian language}

The paper gives a survey of the literature in the Vepsian language based on functional classification. 6 books containing Vepsian texts (incl. a dictionary) were printed in the preliminary period of the Vepsian literature (1853-1931). 32 books in Vepsian were published during the first period (1932-1937), most of them (28) school 
textbooks. On the average, 4.6 books were published per year. Only 4 books came out in the intermediate period (1938-1988). 66 books in Vepsian have been published during the second period (since 1989). 27 of them belong to the belles-lettres, 9 to sacral literature and 9 to reference literature. There are 17 textbooks. At present, on the average of 3 books are published per year in Vepsian language. Unlike during the the first period, much attention is paid to publishing of the belles-lettres and the sacral works. Contemporary Vepsian books are beautiful. The magazine "Kipinä" ('The Sparkle') in Vepsian for children has been issued since 2011 and the bilingual newspaper "Kodima" ('The Native Place') since 1993.

Key words: literature in Vepsian, books, periodicals, functional classification of literature, belletristics 


\section{Tõlke vältimatusest}

\section{Toomas Kiho}

doi:10.7592/PS/28-7kiho

Janika Kronberg helistas mulle eelmisel nädalal just siis, kui olin lugemas Postimeest. Oleksin ma teadnud, et ta oma telefonaadiga tuleb, "oleksin kohe kodust ära läinud", kui fraseerida Oskar Lutsu Tõnissoni. "Tule ja pea Kreutzwaldi päevade avakõne, kõik teised on ära öelnud, kokkulepetest taganenud," ja nii viimasel hetkel ei söanda ta kedagi teist paluda. Härra direktori jutt sarnanes ettepanekuga, mida ei saa tagasi lükata. Ettepanek oli ka täitsa ootamatu. Tunnistan, eriti siinse auditooriumi ees piinlikkusega, et Kreutzwaldi päevad pole minu aastakalendris kunagi tähtsale kohal paigutunud - kuigi tihtigi on Kreutzwaldi päevadel huvitavaid ettekandeid peetud, siin on mõnigi kord olnud seda kultuurilist kõrgtaset ja tulevärki, mida iga kirjandushuviline võiks nautida. Ja seetõttu on kahju, et need kirjaduse tipp-päevad on enamasti jäänud jõuluaegsete askelduste alla või mattunud aastalópu sahmimistesse. Vanal sovetiajal pealegi torgati need päevad teinekord otse jõulude südamesse.

Niisiis eksitati mind lehelugemisel. Mida siis sealt Postimehest olin teada saanud? Lugesin üht hariduse tuleviku arutelu, mis oli Goethe Instituudi rahastusel aset leidnud. Postimees vahendas Mati Heidmetsa sõnu: "Tuleviku ülikoolis on ingliskeelset juttu rohkem. Vaatamata meie ponnistustele eestikeelse haridus- ja teadusruumi osas..." Meie ponnistused?! See on üks halvakõlaline 
sõna, mis väljendab ülemäärast, liigset pingutust... Veelgi selgemalt ja ühemõttelisemalt väljendab sedasama Ott Pärna, Eesti Arengufondi juht. Ja kellelt siis veel kui arengufondlaselt võiks Eesti tuleviku kõige selgemat ettenägemist oodata? Pärna ütleb: "Loodan, et selleks ajaks on kadunud ära veelahe Eesti ja maailma vahel - Eesti kõrgharidus on rahvusvahelistunud, valdav osa õppetööst käib inglise keeles, seda isegi bakalaureuse tasandil. Usun, et alates aastast 2015 on meil teemaks inglise keele tõstmine Eestis teise riigikeele staatusesse ning 2020. aastal see saabki teoks. Inglise keel teise riigikeelena tagab avatuma keskkonna rahvusvahelistele õppejõududele ja nende peredele. /---/ Võimalus siin inglise keeles asju ajada on selle [et Eesti on palju rahvusvahelisem kui praegu - T.K.] vaieldamatu eeltingimus." Ning veel üks üllatav passus Pärnalt: "Inglise keel teise riigikeelena aitab teisalt kaasa vene keelt emakeelena rääkivate noorte ühendamisele Eesti majandusse ja teadusellu"!

Ja seda kõike rahastatakse viigilehe tagant, millele on kirjutatud suure valgustaja Johann Wolfgang Goethe nimi! Kuidas hinnata neid arengufondi fantasme? Kui need pole riigivaenulikud, siis Eesti-vaenulikud on need kindlasti. Vähemalt sellise Eesti vaenulikud, mille nimel on vaeva näinud need sajad ja tuhanded kultuurikandjad, kelle töö viljad on koondatud kas või siia templisse, kirjandusmuuseumisse ja tema hoidlatesse.

Üks ilmekas katke või resümee veel Arengufondi juhatajalt: "Eestist on saanud mitmetes valdkondades teaduselu network'i keskus." - Sellest kumab veendumus saada suureks arvult - seisukoht, mida on Eesti kultuurikonteksis küll alati võimatuks sündmuseks loetud. Vastupidi väitjaid on siinmail leebelt öeldes ullikesteks peetud.

Ja ega Ott Pärna ei ole ju üksi. Lihtsalt tema kui ex officio Eesti arengu suunaja jutupunktidel on suurem kaal kui mõnel niisama ütlejal. Toon veel mõned väljaguugeldunud näited. 
Suhtekorraldaja Raul Kalev kirjutab Delfis 17. mail 2011': "Inglise keele teiseks ametlikuks riigikeeleks nimetamine oleks ennekõike märgilise tähendusega ja minu hinnagul suur samm kultuuri kaitsvast isoleeritusest välja. Ja ka signaal Euroopale, mis ärataks meie vastu ehk suuremagi huvi kui eurotsooniga ühinemine seda suutis.” Kultuuri kaitsva isoleerkihi kõrvalejätmine ei tähendaks ju miskit muud kui omaenda kultuuri eitust, kultuuri mahasalgamist, kultuuritust või (veel heal juhul) ümberkultuuristumist, s.o mõne teise kultuuri isoleerkihi omandamist.

Statistikaameti peaanalüütiku Mihkel Servinski hinnangul on praeguse suuna jätkudes selge, et Eesti võib mingist hetkest elu-olu vabalt kulgeda ka inglise keeles. "Eesti arvamusliidritel on tekkinud mõte ingliskeelse elu-olu loomise vajadusest ja see on avalikult ka välja öeldud. Pragmaatiliselt võttes on mõttel ka jumet võib olla üsna kindel, et ingliskeelse elu-olu keskkonna olemasolu tugevdaks Eesti positsiooni majanduselu rahvusvahelises konkurentsivõitluses," kirjutas Servinski 1. augustil 2011 statistikablogis ${ }^{2}$.

Need on viimase aja näited, kuid ka juba tosina aasta eest kirjutas nt Äripäev (13.9.1999): "Eestisse enim välisraha vahendanud Joakim Helenius avaldas sisuka mõtte, et Eesti peaks kehtestama inglise keele ametlikuks riigikeeleks. Eeskuju on võtta kasvõi Singapurist, sellest äärmiselt kiire majandusarenguga riigist. Äripäev toetab inglise keele kehtestamist riigikeeleks - Eesti muutmist kakskeelseks (eesti ja inglise keel) riigiks. Idee plussid on selgelt näha. Kakskeelsena kiireneb oluliselt Eesti integreeritus Euroopa ja terve muu maailmaga. Välisinvestoritel on palju lihtsam tulla riiki, kus asjad saab korda aetud - jah, seda väljendit pole tarvis karta - rahvastevahelise suhtlemise, s.o inglise keeles. Märkimisväärselt lihtsustub panganduslik, teaduslik, normatiivne ja muu praktika, mis tegelikult käib juba praegu inglise keeles. Lihtsalt mindaks üle de facto'lt de jure'le."

1 http://www.delfi.ee/news/paevauudised/arvamus/raul-kalev-inglise-keelriigikeeleks.d?id=46065875

2 http://statistikaamet.wordpress.com/2011/01/08/rahvaloendus-ja-inglisekeele-oskus/ 
Rahvastevahelise suhtlemise keel, hoolimata Äripäevas väljendatud lootusest, kõlab ikkagi ehtsa reliktväljendina Brežnevi ajast. Ja too oli ju mäletatavasti aeg, millest me kõik ä r a tahtsime, ja kõik selle heaks ka tegime.

Eesti riigi ülesehitusloogikas on alati - nii enne tegelikku riigiloomet või -taastamist kui ka tegeliku konstitueerimise käigus - lähtutud klassikalisest rahvuslusest, millel oli Eesti riigi taastamisel juhtiv roll. Seda vaimu kannab rahvahääletusel ülekaalukalt heaks kiidetud 1992. aasta põhiseadus, mille preambulas on eesmärgina sõnastatud ülesanne tagada eesti rahvuse, keele ja kultuuri säilimine läbi aegade. See on ilmselt viimase aasta jooksul kõige enam meenutatud kirjakoht põhiseadusest. Vähem mäletatakse, et põhiseaduse paragrahv 6 ütleb otsesõnu: "Eesti riigikeel on eesti keel", millega on üheselt välistatud see, et Eestis võiks olla riigikeeleks - kas eesti keele kõrval või eesti keele asemel - mõni muu keel, olgu siis vene või inglise vm. See on olnud üks suur võit, mille eesti rahvas on saavutanud viimaste aastakümnete jooksul - üheks võitluse lähtepunktiks võiks pidada ka 1980. aasta murelikku 40 kirja.

Kuidas on eelöelduga seotud minu teema, tõlke vältimatus? Kõige otsesemalt. Nimelt on päris selge, et inglise keele teise riigikeele staatusesse tõstmine tähendaks Tõlkimatust. Seisundit, kust oleks kadunud tõlke tarvidus, vajadus tõlkimise järele. Sest kui inglise keel on riigikeel, siis on selles keeles kõikvõimalik riiklusele, aga ka kultuurile jm vajaminev teave olemas - kätte- ja arusaadav kõikidele. Kõige eesti keelde ümber panemise järele kaoks vajadus. Aga eestlased tõlkimata ei saa. Eestlane poleks kultuurrahvas ilma tõlkimiseta. Kui nüüd tõlkimise vajadus kaoks, siis vallutaks Tõlkimatuse staadium Eesti kultuuriruumi ning see tähendaks minu hinnangul kaht: kõigepealt, nagu öeldud, vajaduse kadumist tõlke järgi. Kui kõik on juba inglise keeles, siis on tekkinud Paabeli-eelne olukord ning tõlkimine kaob minevikuigandina ajalukku. Kaob 
tõlkekultuur. Kaob vajadus eesti keeles mõtelda ja kirjutada, kaob võõrtekstide kodustamise - mida tõlkimine ju on - tarve. Pikapeale vajub surnud teaduse osasse ka võrdlev filoloogia, kõik tõlketeooriad, meie keel astuks surnud keelte armeesse. Muidugi ei juhtuks see vist veel aastaks 2020, aga varsti ikka. Pääsu ei oleks. Aga eesti tõlkekultuuri kadumine oleks veel väikene häda. Palju suurem mure on teine järeldus. Nimelt tähendaks see kultuuri lõppu üldse. Selline kultuur, kes ei tõlgi, lõpeb. See kultuur vaikiks. Muutuks tühjaks, eimiskiks. Seepärast on kohane hüüatada: arengufond viib meid hukatuse teele!

Kui mu eelnev jutt üldse midagi tähendab, siis ikka just vastupidist: tõlge on vajalik. Tõlge on vältimatu, eriti meile siin, eestlastele. Tõlke vältimatusest kõnelda siin seesuguse auväärt kuulajaskonna ees on ettevaatamatu. Kõik mõistame ju kohe, et iga maailmakultuuri tekst, mis eesti keelde siseneb ehk siis läbib kultuurilise isoleerkihi või kultuurilise atmosfääri, paigutub siin, meie kultuuris, mingile ettemääratud kohale. (See ettemääratuse määr on omaette teema, millel siin peatuda ei tahaks - märgin lihtsalt, et vahel osutub mõni tõlge tähenduslikumaks kui mõni teine, aga milline just, pole alati ette selge. In memoriam Andres Ehini puhul olgu siin ettemääratult kõrgekohalisena mainitud "Tuhandet ja üht ööd". Kreutzwaldi puhul muidugi Kalevipoega, nagu iga tema tõlget ja ükskõik kumba pidi.) Niisiis: tõlgitud tekst saab meie omaks, ja vaheparadoksina: meilt väljatõlgitud tekst jääb meie omaks, mõelgem või vastsele Kalevipoja ingliskeelsele tõlkele. Neil päevil oli Eesti Rahvusraamatukogus väljas näitus eesti tõlkekirjandusest. Eesti kirjanduse teabekeskuse tegevjuhi Ilvi Liive sõnul näidatakse viimase kümne aasta jooksul eesti keelest tõlgitud raamatuid, kokku on näitusel väljas 267 raamatut 27 keeles. Mõlemal juhul, nii meile sissetõlgitud tekstide puhul kui ka väljatõlgitute puhul, on kontekst, raam oluline. Pakend, millesse tekst paigutub. Õigem oleks ütelda: kultuurikontekst, millesse üks või teine nähtus satub. 
Tõlkimine, igakülgse tõlkekultuuri olemasolu on väikesearvulise kultuuri jaoks eriti oluline - selleks et olla täisväärtuslik, koknurentsivõimeline, peame meie eriti palju tõlkima. "Tõlkida, tõlkida nagu hullud," see on "ainus võimalus", kui osundada siin korraga nii Maurust kui Gabrieli, kes ju mõlemad mingis mõttes on olnud eesti kultuuri tõlkijad. Tõlkimine on meie jaoks vältimatu, ta on nagu õhk. Õhku tarbivad nii valaskalad ja suurkultuurid kui uruhiired ja pisikultuurid. See annab meie kultuuriorganismile vajaliku annuse hapnikku, eluõhku, see tähendab uusi mõisteid, mõtestamisi ja ümbermõtestamisi, diskursusi ja paradigmasid. See annab meie lastele võimaluse omandada arusaamine maailmast eesti keele vahendusel. See tähendab olukorda, kus terve ilm alates köögist kuni kosmoseni on seletetav emakeeles. See on ideaalpilt, mida võib vist pidada kogu eesti kultuurilise eksistentsi seniseks keskseks kreedoks ja mõtteks. Selle pildi kooshoidmise ja kokkuseadmise eest oleme kõik vastutavad. Eriti aga tõlkijad. Tõlge on vältimatu!

Ja egas tõlkijad pole ainult luulevahendajad või ilukirjanduse tõlkijad. Tegelikult oleme tõlkijateks me ise, igaüks. Meie enda vastutuses on oma keelt ja väljendusi hoida selged ja klaarid - nagu öeldud: köögist kosmoseni. Köök tähendab siis seda, et me ei risustaks oma igapäevakeelt tarbetute võõrväljenditega, vaid kodustaksime need. Ka kosmose poolel on lugu sama: vältimatu on kinni pidada näiteks nõudest, et väitekirjade kokkuvõtted ilmuksid eesti keeles, et terve mõte oleks eesti keeles olemas, arendatav. Ja ei iialgi valmis.

Ja lõpuks on tõlketekstide hulgas nagu looduslikus ökosüsteemis igal osalisel oma roll: kes on ürask ja kes lagundaja, kes kasvataja, kust tekivad sümbiootilised kontaktid ja kokkupuuted, kus on kõrgelt arenenud vormid ja kus kaunimatest kaunimad õied. Nii on igaühel õigus kohale eesti kultuuripäikese all. Nii Barbara Cartlandil kui Paulo Coelhol, nii Viplalal kui Harry Potteril. 
Kolme olulist mõttelõnga tahaksin ses seoses veel teiega jagada.

\section{1.}

Tõlkevajadus $v s$ emakeelne mõtlemine. Olen üsna kindel, et masinad õpivad üsna varsti tõlkima. Ja see ei tähenda inimeste laiadele massidele mitte mõtlemist, kirjutamist või õppimist inglise keeles, vaid just igaühe emakeeles. Masinad teevad vaid musta töö. See murrang saabub varem või hiljem, nii nagu tänapäeval pesevad pesu masinad ja ka rõivaid õmmeldakse masinatega, niisamuti on varsti võimalik näiteks telefoniliides kuuldetoru ja kõrva vahel, mis tagab selle, et torusse kõneldud teiskeelne jutt moondatakse enne minu kõrva jõudmist eestikeelseks. Näiteid võiks veelgi tuua.

\section{2.}

Tänavu tõi rahvusvaheline suurajakiri National Geographic välja eestikeelse ajakirja. Nemad ei põlga miljonilist kultuuriturgu väikeseks. Eesti keelde pannakse järjekindlalt kogu Euroopa Liidu juriidika, europarlamendi sõnavõtud ja muu sarnane. Ka seal pole eesti keel liiga väeti ega nõder. Arvutisõnavara on viimasel aastakümnel laialdaselt eestindatud, eesti keeles suhtlevad meiega nii Google, IBM kui Apple, seda hoolimata mõnegi hooplemisest, et "kentsakat eestikeelset sõnavara ses asjanduses mina küll omaks ei võta". Ning samal ajal anname meie vabatahtlikult kultuuripositsioone eesti keele käest ära!? See meenutab déjà vu olukorda, kus eesti kadakad aktiivselt saksat pursivad, oma lapsi saksa koolidesse panevad, samal ajal kui edumeelsemad sakslased - parunid, pastorid või literaadid - hoopis eesti keelt ja grammatikat uurivad, eesti keeles värsse kirjutavad ning üldse maarahva harimise peale mõtlevad. 


\section{3.}

Kas olete tähele pannud, et turuliberaalne majandus ei kasuta inglise keelt seal, kus vene keel suuremat sissetulekut tõotab? Ja vastupidi: seal, kus arvatakse, et inglise keel on moekam, seda ka kasutatakse. Näiteks igasugused kommunaalteadaanded prügiveo, olmeelektroonika allahindluste ja kaltsukate kohta, maximate ja onoffide reklaamid, need, mis elanikele postkastidesse jaotatakse, on eesti ja venekeelses paralleeltõlkes. Teine teisel lehepöördel, inglise keel seal puudub. Täna hommikul tõi post sellise lehe: "Ostame kulda ja hõbedat! / Покупаем золото и серебро!”, mitte mingit "We buy gold and silver!"

Seevastu firmanimedes, samuti tootenimetustes eelistatakse inglise keelt, pahatihti isegi eestikeelse vasteta (või on see imepisikirjas, mida keegi lugeda ei näe). Paar näidet tänaselt poeletilt. Ostsin toidupoest ühe kollase purgi, sellel on tekst "Dynami:t. Energy drink. With natural caffeine. 1 pint $=0,568$ 1. 13,6\% for free compared to 0,5 1 bottle - recommended retail sales standard shelf price", ja kaanepaberil seisab "Win a trip to New York". Mitte ühtki eestikeelset sõna, et aru saada, mis peitub purgi sees. Ainus vihje Eestile on veebiaadressi laiend samas kaanel: www.dynamit. ee. (Muide, tegu ongi kodumaise toodanguga, kuid selle teadasaamiseks peab purki luubiga uurima, et matsikeelset teksti näha.)

Või mu teine ost, šokolaad. Mida loeme selle paberilt? Seal on tekst, mis on keeleliselt eriti õel lastele meelepärase toote puhul. Paberit vaadates võib jah arvata, et küllap siin sees, pakendi kuju järgi otsustades, ikkagi šokolaad on, kuid paberile on kirjutatud vaid sellised sõnad: "Kalev Désirée, Caffè latte flavoured milk chocolate with a feeling... and filling." Miks peaksid meie lapsed selle toote eestikeelset vastet teadma või seda tõlkida oskama? 
Tõlke vältimatust tuleb rõhutada kõikjal, aga kindla peale just siin, kirjandusmuuseumis. Kui kõik muu ka langeb, siis... See asutus on nagu meie viimane kants - nagu tsiviilkaitsevarjend, kus üle elada karmid rünnakud (kui tuua paralleel nõukogude ajast), või nagu muistne pelgupaik soosaarel (kuhu sõjarünnakute eest varjuda ning kus säilitada ja säilida). Siia maalinna on aastakümnete jooksul koondatud meie tagavarad, meie kultuurilise kestmise tagatised. Kuni väljas annavad lahingut (keele)vallutajad ja (keele)barbarid ning meie positsioonid nõrgenevad, koguneme seesugustesse kantsidesse nagu kirjandusmuuseum ja peame vastu.

Kirjandusmuuseumi roll rahvusarhiivina, kirjanduse varaaidana, kuhu salvestub järjepidevalt meie kultuurikiht, on ülehindamatu. Kust mujalt seda protsessi veel parem jälgida oleks kui siit kirjandushoidla varasalve servalt. Siin olles ja töötades võib end tunda eelajaloolise molluskina, kelle silme all kirjandus paeseks kultuuripinnaseks ladestub. Aastakäik aastakäigu järel tulevad siia ajakirjad, ajalehed koos oma ajalike murede ja kitsaskohatedega. Aga tulevad ka kopsakad kihid rahvuskultuuri - mõelgem nende all siis teaduslikumaid tekste, kuid eeskätt vist ikka ilukirjandust, seda pärlite pärli, kirjanduse kaunimat kihistust. Ja siin seisab muidugi erilisel kohal Kreutzwald oma Kalevipojaga, nagu on kohane meenutada tänasel päeval, mil siinsamas esitletakse Triinu Kartuse eeposetõlget. 


\section{Kogumisaktsiooni "Looduslike liikide söömine lapsepõlves 2011” eellugu ja aruanne}

Raivo Kalle, Renata Sõukand doi:10.7592/PS/28-8kalle_soukand

\section{Eelnevad kogumised ja uuritus}

Kirjapanekud eestlaste looduslike taimeliikide toiduks tarvitamise kohta ulatuvad juba 18. sajandisse, rohkem on ülestähendusi seoses 19. sajandil Eestimaad tabanud näljaaegadega. Mõned allikad viitavad, et maarahvas korjas tol ajal loodusest taimi söögiks vähe ja mitmedki baltisakslased tegid teavitustööd, et looduslikke taimi rohkem sööma hakataks. Kuid on ka teateid, et maarahvas sõi näljaaegadel liigagi palju looduslike liike. Sellegipoolest ei saa me tagantjärgi teada, milliseid liike ja kui palju siis loodusest tegelikult korjati ja mida neist tehti, sest andmed on väga lünklikud.

Üleüldise suulise pärimuse kogumise ajal 19. sajandi lõpukümnenditel ei pööratud samuti söödavate taimede teemale tähelepanu, sest see jäi lüürilise materjali varju. Alles 20. sajandi 20.-30. aastatel hakkasid Eesti Rahvaluule Arhiiv (ERA) ja Eesti Rahva Muuseum (ERM) pöörama tähelepanu ka perifeersematele pärimusliikidele, sest suund oli võetud üleüldisele pärimuse säilitamisele-kogumisele. Mitmeski kirjalikus küsitlusjuhises oli sees punkt või paar, mis otseselt puudutasid looduslike liikide söögiks kasutamist. Tolleaegne kogumistegevus toimus nn vanavara päästmise põhimõttel ning kuna küsitluskavad koostasid enamasti etnograafid ja folkloristid, võib arvata, et nii ERA kui ERMi selleteemalise materjali uurimine lükkus teadmata tulevikku just erialase botaanilise kompetentsi puudumisel. Nii ERA kui ka ERM kasutasid 
kooliõpetajate abi, paludes nende vahendusel kooliõpilastel täita etteantud küsimustikke. Küsimustike täitmisele aitas kaasa Haridusministeeriumi palve koolidele teha muuseumidega koostööd (vt nt Postimees 1937, 70: 3) ning nagu selgub, olid sellel ka head tagajärjed (vt nt Rahvapärimuste selgitaja 1939, 7: 175; 195). Teiseks kogumise sihtrühmaks olid püsikorrespondendid, kes kahel asutusel paraku oluliselt kattusid. Kogumisaktsioonid korraldati võistluse vormis. Suure panuse andsid ka muuseumi poolt organiseeritud stipendiaatide ekspeditsioonid.

ERA tolleaegset kogutud materjali hakati avaldama sarjas "Endis-Eesti elu-olu". Looduslike liikide söömise kohta on neis andmeid aga üsna napilt, peamiselt sarja II köites ("Lugemispalu metsaelust ja jahindusest”, 1941; 2. trükk 2004) ning need pärinevad enamasti kahelt-kolmelt suurkorrespondendilt. Raamat on pärimustekstide kogu, milles on aineregistrid tekstide paremaks leidmiseks, mitte uurimus.

Esimesed ja seni ainsad uurimused ERMi küsitluskavade vastuste põhjal avaldas 1980ndatel aastatel etnograaf ja toidukultuuri uurija Aliise Moora (1900-1992) ajakirjas Eesti Loodus, kus ilmusid populaarteaduslikud artiklid marjade (1980: 588-592), kadaka (1984: 378-380), taimede (1981: 489-497) ja kasemahla (1982: 298-300) kasutamisest toiduks endistel aegadel (peamiselt kuni Eesti Vabariigi algusaegadeni). Muidugi leidub teateid looduslike liikide kasutamise kohta ka Aliide Moora monograafias (Moora 2007). Autoritel puuduvad andmed, et hilisemate ERMi selleteemaliste küsitluskavade, näiteks 1983. aastal Heiki Pärdi koostatu (KL 168/9) põhjal oleks varem uurimusi tehtud. ERMi materjale metsamarjade kasutamisest on viimastel aastatel mitmes konverentsiettekandes käsitlenud Ester Võsu ja Piret Pungas.

Suurimaks etnobotaaniliseks koguks kujunes Eestis botaanik Gustav Vilbaste (1885-1967) eraviisilise töö tulemus. Ka Vilbaste kasutas kooliõpetajate abi koolilastelt taimepärimuse kogumiseks, kuid lõi lisaks oma infomantide võrgustiku. Ta jõudis oma kogutud materjali küll kohe läbi töötada, kuid kahjuks jäid materjali rohkust arvestades tema uurimused käsikirjadesse (nt "Söödavaid taimi” EKLA, F 152. M 71:8) või käibisid vaid osaliselt avaldatuna. 
Nii juhtus Eesti etnobotaanika suurteosega "Meie kodumaa taimi rahva käsitluses", millest ilmusid vaid esimesed kaks osa (1934, 1935) plaanitavast viiest osast. G. Vilbaste rahastas oma kogumistööd ning raamatute ja ajakirjade avaldamist iseenda palgast ning tegi enamiku sellest tööst oma vabast ajast.

\section{Lapsepõlves söödud looduslike taimede uuring 2011-2012}

Ajalooliste andmete põhjal on ka käesoleva ülevaate autorid avaldanud viimasel ajal mitmeid teadus- (nt Sõukand, Kalle 2012; Kalle, Sõukand 2012; Svanberg jt 2012) ja populaarteaduslikke (nt Kalle, Sõukand 2011a; 2011b) artikleid, mis hõlmavad ajaperioodi kuni 1960. aastateni. Need on esimesed selleteemalised teaduslikud uurimused Eestis. Üleüldine rahvusvaheline suund on aga keskendunud tänapäeva uurimisele. Rahvusvahelise koostöö ning edaspidise teadustöö huvides selles valdkonnas tekkis autoritel niisiis vajadus täiendava andmekogumise ja analüüsi järele. Esimese suuremahulise uuringu aluseks võtsime Poola antropoloogi Łukasz Łuczaj botaanikutele mõeldud ankeedi lapsepõlves söödud looduslike taimeliikide kohta. Esialgne idee oli saada võrdlusandmeid Poola materjalile (Łuczaj, Kujawska 2012). Arvestades Eesti oludega ja olemasoleva materjali hõredusega täiendasime seda ankeeti oluliselt lisaküsimustega ja kaasasime ilma formaalse botaanilise erihariduseta inimesi.

\section{Metoodika}

Kuna uuringu tegemiseks puudus eelarve, siis kasutasime ankeedi levitamisel enamasti isiklikke pöördumisi. Jagasime üle viiekümne ankeedi paberkandjal. Nende tagasisaamine sõltus otseselt hilisemate meeldetuletuste arvust, kuid oli siiski tulemuslik, sest ligi pooltelt küsitletutelt saadi ka vastused. Hilisem täpsustamine oli 
nende puhul aga keerulisem. Elektrooniliselt saadeti välja sadakond isiklikku pöördumist, peamiselt loodus-, kokandus- ja pärimusteemadest huvitatud inimestele; tagasiside protsent selles rühmas oli paarikümne ringis.

Proovisime ka, kui suure tagasiside annab sotsiaalmeedias loodavate võrgustike kaasamine. Keskkonnas facebook.com levitati üleskutset ligi 700 inimesele, liitujaid oli üle viiekümne ning ankeedi saatsid või vabas vormis vastasid neist omakorda pooled. Ankeedi saatsid aga ka mõned aktsiooniga mitteliitunud. Kasutasime ka teisi elektroonilisi võrgustikke, näiteks humanitaar- ja reaalteadlaste erialaliste. Tagasiside listidest jäi 2-5\% piiresse.

Kõige tõhusamaks ankeetide levitamise mooduseks kujunes nn lumepalliefekt, millele aitasid suuresti kaasa selle täitjad ise, kellele oli südamelähedane nii lapsepõlve meenutamine kui ka looduse teema. Eriline tänu Lihula gümnaasiumi bioloogiaõpetajale Marje Loidele, kes kogus kokku ligi 70 vastust õpilastelt ja pereliikmetelt. Tema kogutud materjal on teadaolevalt ajaloo suurim ühe õpetaja kogutud etnobotaanika alane kaastöö Eestis, jäädes alla vaid suurmehe Gustav Vilbaste enda õpetajaametis oldud aastail kogutud materjalile. Samuti avaldame tänu kogumisele kaasa aitamise eest Sofia Hratkevitšile, Tuul Sepale, Ingrid Benderile, Toom Männikule, Mait Taltsile, Külli Eichenbaumile, Anu Rajale, Anneli Luige-Allele, Sirje Kuuderile, Nele Terasele, Kalvi Kivimaale, Merike Peldile, Heldur Sanderile ja kõigile teile, kelle nimesid me ei tea, kuid kelle laiali saadetud ankeedid meieni täidetuna jõudsid.

Mitmedki, kes ise küll ankeeti ei täitnud, jagasid seda elektrooniliselt, saatsid edasi listidesse, millele meil endil juurdepääs puudus, või küsitlesid ja saatsid oma meililt teiste ankeete või oskasid meile soovitada inimesi, kes oleksid huvitatud ankeedi täitmisest. Aitäh abi eest, Kati Taal, Ene Lukka-Jegikjan, Jan Seepter, AnneMai Parring, Ulvi Urm, Marko Prous ja kõik teisedki, kelle nimesid me teada ei saanud. Täname ka Margo Koppelmanni ja Tuuli Mathisenit lahke loa eest kasutada nende blogikirjutisi.

Kuna ankeedi kaaskirjas olid viited meie värsketele eestikeelsetele toidutaimede teemalistele artiklitele, mis on üles laaditud academia.edu keskkonda, siis oli nende vaadatavuste järgi võimalik 
hinnata, kui suur on huvi selle teema vastu. Nagu graafikust (allpool) selgub, on üleskutse igasse uude listi jõudmise järel artiklite vaadatavus hüppeliselt tõusnud. Academia.edu andmetel on 29. veebruari 2012 seisuga artiklit "Ajalooline ülevaade..." vaadatud kokku 366 korda ja artiklit "Eesti looduslikud...” 323 korda.

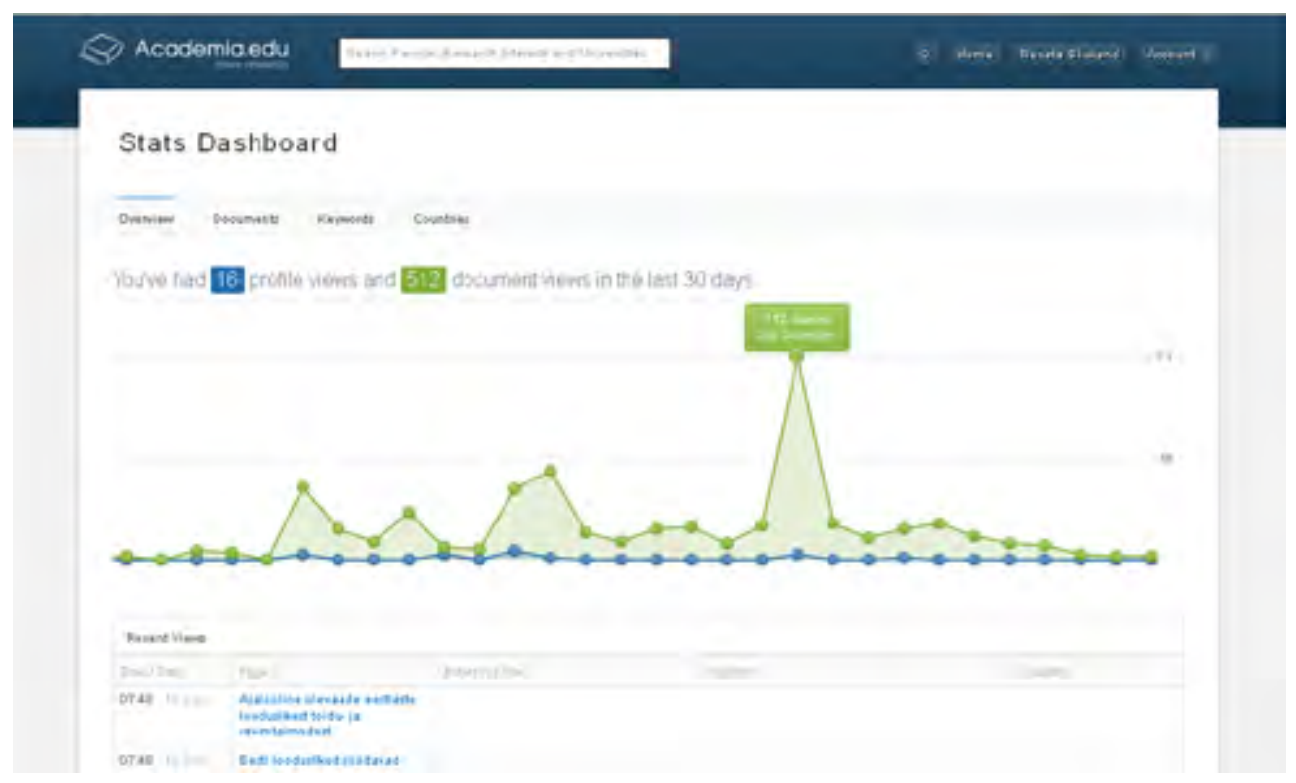

Academia.edu keskkonnas artiklite vaadatavus perioodil 13. november12. detsember 2011.

\section{Tehnilised tulemused}

2012. aasta veebruari lõpu seisuga on meieni jõudnud üle 250 inimese vastused, neist üle 90 paberkandjal. Kuigi aktiivne küsitlusperiood kestis kaks kuud (15.11.2011-15.01.2012), olime ja oleme avatud igasuguse taimepärimuse saamisele ka hilisemal ajal. 5. jaanuaril listidesse saadetud tänusõnade (loe: meeldetuletuse) peale tuli kohe paarkümmend vastust varem alustatud, kuid ajapuudusel pooleli jäänud ankeetidega. 
Elektrooniliselt saabunud vastuste saatjatega toimus kirjavahetus, kus paluti täpsustusi olemasolevatele andmetele (nt toitude retseptid) ja esitati lisaküsimusi, kui loetelust olid puudu mõned väga levinud liigid (nt metsamarjad) või täpsustati mõne taime määrangut. Nii saime omakorda teavet uutest liikidest ja kasutusviisidest. Samuti lisati tihti ankeetidesse ravimtaimi ja seeni koos kasutusega ning taimi, mida praegu süüakse. Kirjavahetus kopeeriti vastava ankeedi juurde. Vastuste pikkus varieerus lehekülgede arvu poolest ühe ja viieteist vahel, kokku koguti üle tuhande A4 lehekülje.

\section{Korrespondendid}

Täname kõiki meie korrespondente: Aadi Remmik, Aavo Omann, Ahto Teeper, Aino Aaspõllu, Aive Sellis, Alar Teras, Aleksander Jakobson, Aleksei Gornev, Andra Migur, Ann Meriste-White, Anne Uusväli, Anneli Luige-All, Anneli Mänd, Annika Mätas, Anti Gruno, Anu Ivask, Anu Jonuks, Anu Raja, Arno-Toomas Pihlak, Asko Berens, Birgit Malmiste, Darja Matt, Eha Kriks, Eike Hanson, Ella-Antonie Kivimaa, Elle Rajandu, Else Altvälja, Emmi Augjärv, Endla Lõhkivi, Enn Sirge, Erika Maasik, Ester Helmrosin, Eva Orlova-Palusalu, Eve Merileet-Kalle, Eve Somelar, Eve Teeper, Evelin Haav, Evelyn Müürsepp, Gea Pulst, Gerda Ruberg, Gloria Niin, Gretel Kärbline, Hedvig Lätt, Heinrich Lukk, Heldur Sander, Helgi Avistu, Heli Kõllamägi, Helina Laurits, Helju-Endla Hlusova, Hellen Allik, Heya Lepa, Hiie Pajur, Imbi Rüütel, Imre Masing, Inga Riik, Ingmar Haav, Ingrid Bender, Ingrid Ploom, Jaanus Nõgene, Janet Peet, Juta Müllerstein, Jürgen Kirsis, Jürgen Kusmin, Kadi Jairus, Kadi-Liis Kesler, Kadri Kõivik, Kadri Novikov, Kadri Raudsepp, Kadri Riit, Kadri Sohar, Kadri Tali, Kaili Kaasik, Kalvi Kivimaa, Karin Asi, Katriin Hõim, Katrin Kaldma, Katrin Laikoja, Katrin Satsi, Kerli Altmart, Kersti Puusild, Kirsi Loide, Krista Kallavus, Kristel Vilbaste, Kristi Nigul, Kristiina Ehapalu, Kristiina Pärk, Kärt Mikli, Kärt Pettai, Külli Allik, Külli Eichenbaum, Külli Samuel, Lagle Aim, Laine Luige, Lea Hallik, Lea Mikkelsaar, Lee Põllumaa, Lii Nool, Liina Eek, Liina Paales, 
Maarika Toomel, Madis Kuningas, Maie Maripuu, Maie Palmeos, Maire Karind, Mait Talts, Mall Hiiemäe, Malle Leht, Mare Kõiva, Mare Leis, Maret Schultz, Margit Düüna, Margit Prous, Margus Franz, Mari Hiiemäe, Mari Lepik, Maria Noormets, Marika Kose, Marit Otsing, Marje Käis, Marje Loide, Marko Puksing, Mart Kalle, Mart Vaus, Mati Kaal, Meeli Mesipuu, Meelis Kütt, Merike Peld, Merle Kösler, Merle Taniloo, Milvi Roots, Monika Suškevičs, Nele Terase, Niina Kivimaa, Olev Stelmach, Pilvi Liivamägi, Piret Piip, Piret Pungas, Piret Punt, Piret Raja, Piret Raudsepp, Priit Pedastsaar, Pärtel Relve, Rain (Põlvamaalt), Raivo Mänd, Reet Hiiemäe, Reet Paloson, Reti Kooser, Riho Marja, Ruth Paas, Sigrid Korts, Siiri Kuus, Siiri-Lii Sandre, Silja Erg, Sille Kase, Silvia Looveer, Simo Stahlman, Sirje Kuuder, Sirje Pajumägi, Sofia Hratkevitš, Taimu Kalle, Tambet Tõnissoo, Tarmo Timm, Terje Tähtjärv, Thea Kull, Tiina Konsen, Tiina Leppmaa, Tiina Luige, Tiina Sootalu, Tiina Tullus, Tiiu Raaper, Tiiu Suurkask, Toivo Sepp, Toom Männik, Triin Kusmin, Tuul Sepp, Tuuli Mathisen, Tõnis Aro, Tõnu Talvi, Uno Schultz, Urmas Kalla, Urve Kivilaid, Vaike Aston, Valentina Kuzina, Vello Helk, Vello Veski, Viire Villandi, Viivi Lillemägi, Vivika Meltsov ja Õie Köösel.

Eraldi tänu Lihula Gümnaasiumi õpilastele: Aimar Mänd, Aleksander Saak, Andra-Liis Junker, Carl Vinkel, Carol Kolga, Deevi Kumer, Eerik Rummi, Egert Indres, Elise Ojap, Ergo Gelenitš, Fred Martin Mägi, Geithi Rammul, Grete Kivinukk, Grete-Mai Bauvald, Helina Põhja, Henrik Palm, Jaak Aru, Jaanika Teppan, Joonas Kaskmäe, Juhan Sepp, Kai Simpson, Kaidi Koljo, Kaisa Esko, Karin Mänd, Karmel Üksvärav, Kert Pääbo, Kristi Kalde, Kristi Kumpas, Kristjan Mets, Kuldar Veek, Kätlyn Kleinod, Liis Õunapuu, Liset Kuusik, Maarja Jalakas, Maarja-Liis Vesiloik, Marek Pastjan, Margit Grencštein, Margus Indres, Maria Mölder, Marina Mager, Marius Roos, Markus Pastjan, Martin Taimre, Meriliis Ojamäe, Nele Šmõtskov, Rael Ellermaa, Ragne Nikkel, Raido Heinlaid, Raili Õunapuu, Rain Kruusel, Remo Oosim, Reneda Viherpuu, Renee Pärnpuu, Riina Kivisalu, Rita Nazarova, Sander Kais, Sander Vesiloik, Signe Mägist, Tanel Mets, Tavo Grau ja Teele Meriste. 
Aitäh, Esti Koppel, Kaili Kaasik, Pilvi Põller, Ruth Paas, Siiri Saar ja Ulvi Peeters autoritele 2011. aastal üldise taimepärimuse saatmise eest, mis andis usku ja lootust suurema kogumisaktsiooni õnnestumiseks.

\section{Kokkuvõtteks}

Kogutud materjal võimaldab võrrelda eri ajajärke looduslike taimede kasutuses. ${ }^{3}$ Peamiseks eeliseks on, et taimeliike saab statistiliselt paremini analüüsida, sest iga taimeliigi kohta on vastatud ühesuguste küsimuste alusel. Varasematel aegadel on küsitlustes lähtutud kas vabas vormis taimeloenditest ilma täpse kasutuseta või valikvastustest, s.t on kasutatud erinevaid meetodeid, mida on raske omavahel ühildada ning statistiliselt analüüsida. Käesoleva kogu erakordsus võrreldes nii ERA, ERMi kui ka Gustav Vilbaste samateemaliste kogudega on: 1) metoodika erinevus, 2) elektrooniline küsitlus, 3) vastajad olid valdavalt kõrgharidusega või seda omandamas, ligi poolsada neist doktorikraadiga või seda omandamas. Varasemates küsitluste vastajate hulgas domineerivad kooliõpilased ja suurkorrespondendid; seekordne küsitlus annab parema läbilõike ühiskonnast ja on detailirohkem. Mõndagi vastajat motiveerisid just üleskutses viidatud ajalooliste andmete põhjal kirjutatud artiklid, sest neid läbi lugedes tuli lapsepõlves kogetu paremini meelde. Need artiklid said valmida vaid tänu eelnevatel aegadel kogutud pärimusele. Varasematel kogujatel ei olnud paraku millelegi toetuda ja nii oli neil tunduvalt raskem oma uuringut metodoloogiliselt üles ehitada.

Kogutud andmed antakse peale paberkandjal olevate ankeetide digiteerimist ja kogu korrastamist ning andmete analüüsimist ja tulemuste publitseerimist üle Eesti Kirjandusmuuseumi Eesti Rahvaluule Arhiivile.

3 Tänapäeva järjest suurenev huvi looduslike ja traditsiooniliste toitude vastu on ka eestlastel tõstnud moodi just looduslikud toidutaimed. Näiteks guugeldades (08.02.2012.) märksõna "umbrohutoidud", andis otsimootor 1060 vastust, millest enamik on internetti ilmunud viimastel aastatel. 
2013. aasta detsembri seisuga on kogutud materjali põhjal juba ilmunud raamat looduslikest toidutaimedest (Kalle, Sõukand 2013a) ning kaks ingliskeelset artiklit, esimene analüüsib bioloogia taustaga inimeste poolt kogutud materjali (Kalle, Sõukand 2013b) teine kompab piiri tee- ja ravimtaimede vahel (Sõukand, Kalle 2012).

\section{Kirjandus}

Kalle, Raivo; Sõukand, Renata 2013a. Eesti looduslikud toidutaimed. Kasutamine 18. sajandist tänapäevani. Tallinn: Varrak.

Kalle, Raivo; Sõukand, Renata 2013b. Wild plants eaten in childhood: retrospective of 1970s-1990s Estonia. - Botanical Journal of the Linnean Society 172, pp. 239-253.

Kalle, Raivo; Sõukand, Renata 2012. Historical ethnobotanical review of wild edible plants of Estonia (1770s-1960s). - Acta Societatis Botanicorum Poloniae 81 (4), pp. 271-281.

Kalle, Raivo; Sõukand, Renata 2011a. Ajalooline ülevaade eestlaste looduslikest toidu- ja ravimtaimedest. A historical overview of the Estonians' wild food plants and herb. - Metsa kõrvalkasutus Eestis. Akadeemilise Metsaseltsi toimetised XXV. Tartu, lk 29-44.

Kalle, Raivo; Sõukand, Renata 2011b. Eesti looduslikud söödavad taimed. Haridus nr 3, lk 34-36.

Łuczaj, Łukasz Jakub; Kujawska, Monika 2012. Botanists and their childhood memories: an under-utilized expert source in ethnobotanical research. - Botanical Journal of the Linnean Society 168, 1k 334-343.

Moora, Aliise 2007. Eesti talurahva vanem toit. Tartu.

Svanberg jt 2012 = Svanberg, Ingvar; Sõukand, Renata; Łuczaj, Łukasz; Kalle, Raivo; Zyryanova, Olga; Dénes, Andrea; Papp, Nóra; Nedelcheva, Aneli; Šeškauskaite, Daiva; Kołodziejska-Degórska, Iwona; Kolosova, Valeria. Uses of tree saps in northern and eastern parts of Europe. - Acta Societatis Botanicorum Poloniae 81(4), pp. 343-357.

Sõukand, Renata; Kalle, Raivo 2012. The use of teetaimed in Estonia, 1880s-1990s. - Appetite 59(2), pp. 523-530. 


\section{KIVIKE - Kirjandusmuuseumi virtuaalne kelder}

Kadri Tüür

doi:10.7592/PS/28-9tyyr

On üsna üldine tõdemus, et igasugune identiteet põhineb mälul. Kirjakultuuri tingimustes talletub suur osa kultuurimälust kirja pandud tekstidesse, need omakorda kogumiseks, säilitamiseks ja läbi töötamiseks mõeldud mäluasutustesse. Üks osa säilitamistegevusest ennetava ja korrigeeriva kõrval on alati varukoopiate tegemine, mida saab rakendada eeskätt kirjalike allikate puhul. Ajaloo jooksul on koopiate tegemine toimunud küll käsitsi ümber kirjutades, mehaaniliste trükipresside abil, viimasel sadakonnal aastal üha enam keemiliste jäljendusviiside kaudu (mimeograaf-, hektograafpaljundused, kopeerpaber) või fototehnoloogiat kasutades (ümberpildistamine, mikrofilmimine, kserokoopiad). 21. sajandil on peamiseks kopeerimistehnoloogiaks muutunud skaneerimine, mille käigus info muudetakse digitaalselt töödeldavaks. Samuti sünnib järjest rohkem säilitamisväärset materjali elektroonilisena; koopiaks on siis hoopis paberkandja. Paljudel juhtudel on aga digitekkeline info sellise iseloomuga, et teda ei saagi paberile trükkida (kasvõi nt animeeritud ppt-slaidid).

Ühest küljest muutuvad kultuuriloolised allikad seeläbi arvuti, elektri ja internetiga varustatud inimestele hõlpsamini kättesaadavaks nende füüsilisest asukohast sõltumata. Teisalt toob digitaalse informatsiooni säilitamine endaga kaasa hoopis teistsugused väljakutsed kui paberarhiivide hoidmine ja hooldamine. Digitaalsed objektid on oma olemuselt äärmiselt komplekssed ning ükski selle komponentidest ei ole inimese jaoks arusaadav eraldiseisvana. Digitaalsel objektil võib eristada füüsilist, loogilist ja kont- 
septuaalset tasandit. ${ }^{4}$ Digitaalse objekti füüsiliseks tasandiks on andmekandjale salvestatud bitid. Loogilisel tasandil tuvastatakse tarkvara abil bittide kodeering, mis tagab inimese juurdepääsu talletatud info kontseptuaalsele tasandile. Ka selliste keerukate objektide pikaajaline säilitamine erineb mõnevõrra analoogobjektide säilitamisest, kuna mälumaterjali kasutatavana hoidmiseks ei piisa enam pelgalt füüsilise objekti säilimise tagamisest. Samuti sõltub digitaalse materjali säilitamine ja kasutamine elektrivarustusest.

Keerukuse vähendamiseks on digitaalse ainese säilitamisel lubatud "taandada" algne fail mõnesse staatilisse ning enamasti ka automaatselt metainfoga varustatud formaati (tiff, pdf, wav). Seesama "taandamine" leiab aset ka digitaalsel kopeerimisel. Me peame leppima sellega, et köite lõhna ja lehtede krabinat asendab kahemõõtmelise ekraani klikkimine; tehnilise poole pealt lisandub säilikute sisu kirjeldustele ka hulk tehnilist metainfot nende kujutiste kohta, mis võimaldavad selle hilisemat säilitamist ja vajadusel vormingute muutmist. Digitaalse säilitamise protsess ei tähenda enam ainult säiliku füüsilise kandja seisundi jälgimist, vaid ka reageerimist muutustele teda avavates tarkvarakeskkondades ning vajaduse tekkides säilitatavate failide ümber salvestamist teises vormingutes. IT-valdkonna arengu kiiruse ja ärilise iseloomu tõttu on digitaalne säilitamine muidugi suhteliselt spekulatiivne valdkond ja toimib praegu tihti veel hea õnne peale. Oma säilitusvalikuid tehes ja dokumenteerides teeme aga vähemalt nii palju, et ehk saab keegi tulevikus meie võimalikest möödapanekutest õppust võtta.

Eesti Kirjandusmuuseumis kaks aastat väldanud projekti "Eesti trükise Punase Raamatu ja eesti kultuuri käsikirjaliste alliktekstide säilivuse ja kättesaadavuse tagamine” tulemusena on 2012. aasta kevadeks valminud uus digitaalarhiivi keskkond, mis on Eesti rahvaluule ja kultuuriloo huvilistele kättesaadav aadressil kivike.kirmus.ee. Kivike on nii kirjandusmuuseumi arhiivide ühine andmebaas kui ka institutsionaalne repositoorium, kus säilitatakse ja tehakse nähtavaks väärtuslike materjalide digitaalseid

4 Toetun järgnevas Raivo Ruusalepa ja Kuldar Aasa loengumaterjalidele digitaalsest säilitamisest 18.05.2010. 
koopiaid. Järgnevas käsitlen lähemalt Eesti Kirjandusmuuseumi digitaalarhiivi Kivike loomise lähtekohti, protsessi ja mõningaid sellega seoses üles kerkinud küsimusi, mida eritlen Kivikese uurijakeskkonna näitel.

Digitaalse säilitamise kui suhteliselt noore valdkonna puhul on oluline korrastada ka terminoloogiat, milleks siinkohal on hea võimalus. Kivikese puhul räägime repositooriumist, mis on digitaalse materjali pikaajaliseks säilitamiseks mõeldud tarkvarakeskkond kombineerituna turvaliseks säilitamiseks sobiva riistvaraga, nagu serverid, varukoopiate tegemise seadmed, varu-toiteseadmed elektrikatkestuse puhuks jne. Repositooriumis hoitakse suuremahulisi tagatisfaile koos nende kohta käivate tehniliste andmetega, mis on vajalikud selleks, et näiteks kahekümne või viiekümne aasta pärast oleks võimalik tuvastada, missuguse tarkvara abil nad on tehtud, missuguse abil on neid muudetud ja missugust peaks kasutama nende edaspidiseks avamiseks ja/või muutmiseks.

Mingil moel peab loomulikult olema võimalik tuvastada ka nende failide sisu. Sellel otstarbel on failid enamasti seotud andmebaasiga, mis sisaldab sisulisi andmeid nende kohta. Failid ja andmebaas ei pea tingimata asuma ühes serveris ja ühes süsteemis, nad võivad olla omavahel seotud ka mingite formaliseeritud linkide abil. Näiteks trükiste failid Kivikeses on varustatud iga teose bibliokirje numbriga. Selle abil on võimalik panna masinad automaatselt seostama faili ja sama bibliokirje numbrit sisaldavat andmebaasikirjet Eesti raamatukogude kataloogis ESTER. Kivikesse on võimalik need kirjed ka üle tõmmata, mis ühelt poolt muidugi dubleerib juba olemas olevat andmebaasi, teisalt aga tagab parema informatsiooni meie failide kohta ning seeläbi loodetavasti ka nende parema säilimise. Kolmas oluline mõiste digitaalse kultuuripärandi puhul on esituskeskkond - hea kujundusega võrgukeskkond, kus nähtav ja otsitav materjal on kasutajate jaoks juba eelnevalt mingil alusel ja kindlal eesmärgil selekteeritud. Esituskeskkonnas näidatakse tavaliselt võrgukvaliteedis (ehk siis madalama resolutsiooniga) faile ning enamasti luuakse neid hariduslikel eesmärkidel. Esituskeskkondade kaudu saavad mäluasutused oma kogusid populariseerida; võimatu pole ka nende kasutamine 
meelelahutuslikel eesmärkidel või kasutajaid täiendava sisu loomisele kaasa kutsudes. Kirjandusmuuseumi kõige tuntum esituskeskkond on ilmselt "Kreutzwaldi sajand", mis kasvas välja Fr. R. Kreutzwaldi 200. sünniaastapäevale pühendatud näitusest, kuid on laienenud kogu 19.-20. sajandi Eesti kultuuriloo allikaid ja sündmusi tutvustavaks võrgupaigaks. See keskkond ei arene stiihiliselt, vaid seda kujundavad pidevalt Eesti Kirjandusmuuseumi teadurid, valides, mida ja kuidas seal esitada. "Kreutzwaldi sajand" on seotud Kivikesega sel moel, et seal esitatavate failide tagatiskoopiad on hoiul Kivikeses ning administraatori-taseme otsinguga leitud jpg-failid suudab Kivike sellesse süsteemi eksportida.

Projekti "Eesti trükise Punase Raamatu ja eesti kultuuri käsikirjaliste alliktekstide säilivuse ja kättesaadavuse tagamine” käigus digiteeriti Eesti Rahvusraamatukogus enam kui 1300 Eesti trükise Punase Raamatu nimekirjadesse kuuluvat haruldast trükist. Tartu Ülikooli Raamatukogus digiteeriti tervikuna Jakob Hurda rahvaluulekogu (163 köidet), Eduard Philipp Körberi kodulooliste materjalide kogu (27 köidet) ja Ado Grenzsteini kirjakogu (18 köidet). Punase Raamatu nimekirja trükised on kogumina leitavad elektronkataloogis ESTER; käepärane on neid lehitseda Eesti Rahvusraamatukogu digitaalarhiivis DIGAR. Kivikese kaudu on uurijatel ligipääs heakvaliteedilistele pdf-failidele ja võrgus lehitsemiseks sobivatele jpg-failidele. Vastavalt iga arhiivi kasutustingimustele võib uurijatel olla vaja failide vaatamiseks Kivikesse siseneda ID-kaardiga. Säilikute kirjeldusi saab lehitseda ka ilma sisse logimata. Suuremahulised tiff-formaadis tagatisfailid on Kivikeses kättesaadavad vaid autoriseeritud kasutajatele. Kivikest täiendatakse jooksvalt iga päev. Järgmise suure etapina digitaalarhiivi arendamisel on kirjandusmuuseumil kavas helikogu arendustööd.

Põhimõtteliselt on Kivikese baasil võimalik ka mistahes teiste esituskeskkondade loomine.

Siin on aga mitmeid olulisi küsimusi, mille lahendamine nõuab ilmselt tõsist mõttetööd ja osaliselt ka unikaalsete dokumentide põhise arhiivipraktika ümberhindamist digitaalses keskkonnas. 
Virtuaalse keldri sisustamisel on kerkinud mitmeid probleeme, mis puudutavad nii arhiivide töötajaid kui kasutajaid. Järgnevas leiavad käsitlemist vaid mõned olulisemad, kus kasutajate tagasiside vast kõige enam põhimõttelisi otsuseid langetada aitaks.

Juurdepääs arhiividele on ajalooliselt olnud reguleeritud nii, et materjalidega tutvumiseks peab omama teatud staatust, kvalifikatsiooni või luba (meenutagem näiteks nõukogude-aegseid erifonde või ülikooli liikmeks olemise nõuet mitmetes akadeemilistes raamatukogudes). Ka Kivikese puhul on ligipääs selle mõnedele osadele piiratud. Riigi kui rahastaja poolne tingimus loodavale süsteemile oli, et autentimine peab vajadusel toimuma Eesti Vabariigi ID-kaardi abil. Iga osalev arhiiv ise sai valida, milliste materjalide vaatamiseks tuleb vaatajal end identifitseerida. Kui traditsiooniliselt on iga unikaalse (paberil) arhiivisäiliku kasutaja pannud end kirja ning kinnitanud enda isikusamasust allkirjaga, siis kas digitaalse materjali vaatamisel peaksid toimima sama ranged põhimõtted?

Siin tekib hulk põhimõttelisi küsimusi, millele hetkel vastust ei ole, aga mis kindlasti vajaksid kaasamõtlemist, nagu näiteks: Millised on kasutaja või säilitaja jaoks digitaalse materjali olemuslikud erinevused võrreldes näiteks korduval kasutamisel mehaaniliselt kuluva paberkandja või magnetofonilindiga? Millised on võimalikud alternatiivid ID-kaardiga autentimisele - sest me ei saa eeldada, et kõik eesti kultuuriloo ja rahvaluule huvilised üle kogu maailma omavad ID-kaardi-võimekust? Kui inimene kasutab näiteks tahvelarvutit või nutitelefoni, siis ta tõenäoliselt ei hakka ennast ID-kaardiga sisse logima. Võimalik on kasutada mobiilID-d, aga see ei pruugi palju mugavam olla. Samuti on ID-kaardi taga olevad materjalid piiranguks väliste süsteemidega liidestamisele, sest kõiki väliseid päringuid, hoolimata sellest, kas neid teeb inimene või masin, käsitleb Kivike kui autentimata kasutajat ja annab talle välja ainult neid faile ja andmeid, mis on tundmatule kasutajale lubatud.

Teisalt on, eriti 20. sajandi teisest poolest alates kogutud rahvaluule seas materjali, mis võib sisaldada delikaatseid isikuandmeid (nt inimese usuliste tõekspidamiste kohta, või mõne naabruses elava inimese kohta intervjuus öeldud asi, mida teine võib pahaks 
panna) ja mille väljaandmine peab olema kontrollitud. Ometi, kui tegemist on mahukate digifailidega, on nende hoidmiseks kõige õigem koht siiski repositoorium. Loomulikult saab säilikuid suletuks (olek: passiivne) märkida ka ühekaupa või lausa palade kaupa, aga siin on küsimus protsessi automatiseerimise ja käsitöö vahelises tasakaalus.

Nii digiteerimisel kui andmebaasikirjete koostamisel kerkib küsimus, milline on optimaalne esitatava metainfo hulk. Ühelt poolt seavad tehnilised standardid üldise metainfo kasutamisele suhteliselt kitsad raamid. Teisalt aga on eri arhiivides aastakümnete pikkuse praktika alusel välja kujunenud väga detailsed viisid oma materjali kirjeldamiseks, mille ühtlustamine isegi ühe asutuse piires võib osutuda ootamatult keerukaks ülesandeks. Järjest laieneva ühisotsingute ning semantiliste seoste abil toimiva linkimise tingimustes on metainfo standardiseerimine siiski möödapääsmatu. Kuidas aga leida tasakaalu ühtlustatud üldinfo ja materjalispetsiifilise peenkirjelduse vahel? Kuidas esitada otsingu tegijale just see õige kogus võimalikke valikuid?

Kivikese liitotsingu puu on üsna haruline ja seda on olnud raske süstematiseerida, osalt seetõttu, et iga arhiiv on oma märgendamissüsteemi arendanud omal moel. Eriti arhiivitöö puhul tuleb ajalooline traditsioon enamasti arvesse kõva argumendina, mille tõttu on kogude kirjeldamises reforme suhteliselt raske esile kutsuda. Võib aga arvata, et "huviline internetist" (kes asendab varasemat "inimest tänavalt") satub sellisest parameetrite paljususest kergesse segadusse, iseäranis, kui tema huupi sooritatud otsingud esimesel kolmel korral mingit efektset tulemust ei anna. Siin on variant pakkuda sisse logimata tavakasutajale mingit lihtsustatud hulka otsinguparameetreid ja viidata otsingujuhendis, et kui ta tahab oma otsivõimalusi mitmekesistada, peab sisse logima. Ühe praktilise abivahendina on praegu Kivikeses sisse viidud liitinfo väli, millele koondatakse automaatselt sisuline metainfo neljalt igale arhiivile kõige olulisemalt väljalt (igal arhiivil eri järjekorras!), mis ilmub iga õnnestunud päringu juures (juhul, kui otsija taipab sisestada näiteks Hurda köite viite, mis talle korraga palju ilusaid tekstipilte pakub). 
Päringutest ei ole aga enam pikk maa autoriõiguste küsimuseni: digitaalse materjali paljundamist on ju peaaegu võimatu blokeerida. Kuidas teavitada kasutajaid nende käsutusse antud materjalide kasutamise reeglitest nii, et see mõjus oleks ja meelde jääks? Üks kõige olulisemaid mureküsimusi on ilmselt viitamine. Iga säiliku juures on Kivikeses metaandmeväli "viide", kuid tänapäeva copy-paste-kultuuris on ju hoopis lihtsam aadressiribalt kogu pikk joru oma uurimusse kopeerida ja ütelda, et seal see on. Lisaks sellele saab iga fail repositooriumisse laadimisel automaatselt oma püsiidentifikaatori, mis sisaldab faili repositooriumi panemise kuupäeva ja veel hulka automaatselt genereeritavaid numbreid. PID-i järgi on põhimõtteliselt võimalik sama faili samast süsteemist hiljem kiirotsinguga kiiresti üles leida, aga iseseisva numbrijoruna väljaspool süsteem ei ole tal suurt mõtet. Seega ei tohiks ka seda viitamisel kasutada. Lihtsalt üteldes: digitaalse säiliku viide on seesama mis pabersäilikul, lihtsalt tema vaatamise koht ei ole mitte uurijatesaal kirjandusmuuseumis, vaid näiteks arvutiekraan Tallinn-Tartu rongis.

Samuti on olnud juttu sellest, mis tüüpi autoriõigustega on meil arhiivimaterjalide puhul tegemist ja kas autoritena tuleks käsitleda materjali jutustajaid, loovutajaid, kogujaid, töötlejaid või koguni kõiki nimetatuid? Viimasel juhul muutuks materjalide avalikustamine muidugi eriti komplitseerituks (iseäranis, kuna lahkunud isikute puhul tuleb üles otsida ja luba paluda nende järeltulijatelt). Autoriõigustega tegelevate juristide sõbralik soovitus on olnud mitte selle teemaga lolliks minna. Läti kogemus ütleb, et kolme aasta pikkuse intensiivse digiteerimistöö tulemusena on tulnud digiteeritud materjali algse autori järeltulijatelt üks järelepärimine, mis saadi sõbralikult lahendatud. Failirepositooriumi projekti rahastust vahendanud Majandus- ja Kommunikatsiooniministeerium soovitab kasutada creative commons'i litsentse; "Kreutzwaldi sajandi" esituskeskkond seda juba teebki.

Kokkuvõtteks võib tõdeda, et Kivike annab oma panuse uute võimaluste loomisesse arhiiviuuringute-põhises uurimistöös, kuid tasakaalu võimaluste ja piirangute vahel tuleb mitmeski punktis veel otsida. 
2011. AASTA KROONIKA

doi:10.7592/PS/28-10kroonika 


\section{Eesti Kirjandusmuuseum 2011. aastal}

\section{Janika Kronberg}

2011. aastal oli Eesti Kirjandusmuuseumi teadustegevuse põhilisteks alusteks 5 sihtfinantseeritavat teadusteemat, mida toetasid baasrahastus, 7 ETF-i ja 2 järeldoktori granti. Lisaks pakkusid tõhusat tuge riiklikud programmid, Rahvuskaaslaste programm, suuremahulise digiteerimise vallas Riigi Infosüsteemi Amet ning sihtasutus Unitas, kirjastamisprojekte toetas peamiselt Eesti Kultuurkapital. Sihtasutuse Archimedes vahendusel oli struktuurifondide toel käimas kaks suurt projekti - Eesti Kirjandusmuuseumi juurdeehitus ja failirepositooriumi arendamine.

Muuseumi teadustööd ja koostööd teiste teadusasutustega elavdas kevadine tippkeskuse taotluse kirjutamine, mis ei andnud küll positiivset tulemust, kuid avas uusi perspektiive edasiseks ühistegevuseks Eesti Kunstiakadeemia, Underi-Tuglase Kirjanduskeskuse ning Tartu Ülikooli kirjandusteadlaste ja ajaloolastega. Rahvusvahelist koostööd arendati kõige enam Bulgaaria ja Poola teadusasutustega, pikemalt viibisid teadlasvahetuse korras Eesti Kirjandusmuuseumis uurijad Gruusiast, Bulgaariast ja Soomest. Doktorikraadi kaitses 2011. aastal 5 Eesti Kirjandusmuuseumi teadurit: folkloristid Anneli Baran, Mare Kalda, Andreas Kalkun ja Piret Voolaid ning kultuuriteooria töögrupi liige Eva Näripea.

Arhiivraamatukogu kogud täienesid jätkuvalt sundeksemplaride laekumise ja järelkomplekteerimise teel, olulist lisa saadi kirjanik Leo Metsari pärandist. Suurema tegevusena jätkus Eesti Punase Raamatu digiteerimisprojekt Kadri Tüüri juhtimisel. Tema eestvõttel toimusid ka digiprojekti mõttetalgud Muhus ning aasta algul ilmus asutuse ühistööna kalender. Osakond osales veebrua- 
ris aktiivselt Kultuuriteooria tippkeskuse vanaraamatu teemalises doktorikoolis "Workshop Cultural memory and the archive: selection, conservation, transformation". Koostööd tehti kõige enam Tartu Ülikooliga, pakkudes üliõpilastele praktikabaasi, ning Tartu Kõrgema Kunstikooliga vanemate trükiste restaureerimise ja konserveerimise alal. Tartu Linnavalitsus tunnustas arhiivraamatukogu töötajat Ave Pilli parima muuseumitöötaja tiitliga.

Eri osakondi koondav suursündmus Eesti Kultuuriloolise Arhiivi elus oli "Kalevipoja" uue ingliskeelse tõlke avaldamine koos eestikeelse originaaltekstiga. Tegemist on juubeliväljaandega, millega tähistati "Kalevipoja" tervikuna esmailmumise 150. aastapäeva. Tõlke autoriks on Austraalias elanud Triinu Kartus ja see on illustreeritud Gunnar Neeme piltidega. Toimetamistöö jõudis lõpule viia Harry Mürk Torontos ja teksti varustas ingliskeelsele lugejale hädavajalike kommentaaridega Bloomingtoni Ülikooli folklorist David E. Gay. Väljaande projektijuht oli Eesti Kultuuriloolise Arhiivi vanemteadur Marin Laak. Oktoobris toimus koostöös Tartu Ülikooliga ka "Kalevipoja" juubelile pühendatud rahvusvaheline konverents.

2011. aastal olid mahult suuremad laekumised Eesti Kultuuriloolise Arhiivi kogudesse Fanny de Siversi, Ilse Lehiste, Leo Metsari, Andres Vanapa ja Helju Valsi terviklikud personaalarhiivid, lisa tuli Bernard Kangro ja Valmar Adamsi isikukogudele. Arhiivi jõudsid veel ligi 500 Vaino Vahingu kirja Ilvi Jõe-Cannonile USAsse ning Underi-Adsoni kirjad Õie Fleigile aastaist 1948-1974. Inno Salasoo Austraaliast annetas Metsaülikooli materjalid, fotokogu täienes Salme Ekbaumi pildialbumitega ning fotograaf Kalju Suure negatiividega kirjanikest. Jätkuprojekti "Kirjanik ja tema keskkond" raames pildistati 29 eesti kirjanikku. Digiteeriti Ado Grenzsteini kirjakogu ning suurem osa Martin Körberi kogust, jätkus Teataja fotoarhiivi ja Eesti Muinsuskaitse Seltsi kogude digiteerimine. Villem Reimani 150. ja Arno Vihalemma 100. sünniaastapäeva tähistamiseks koostati kogudepõhised näitused ning korraldati konverentsid. Koostöös Tallinna Ülikooliga toimus rahvusvaheline autobiograafiauurijate konverents "Trajectories of (Be) longing”. Olulisemad teadustöödena ilmunud trükised olid Fried- 
rich Robert Faehlmanni “Teoste" kolmas köide ja eepose "Kalevipoeg” kakskeelne väljaanne. Ilmus ajakirja Methis jätkunumber ning laekunud elulugude põhjal raamat "Sõjas kasvanud poisid".

Eesti Rahvaluule Arhiivi tooniandvamad 2011. aasta trükised on seotud kohapärimusega: Valdo Valperi koostatud "Metsast leitud kirik. Mõtsast löütü kerik. Urvastõ kohapärimus” ning Mari-Ann Remmeli Rae valla aastapäevaks ilmunud "Päritud paigad. Kohajutte ja legende Rae vallast” põhinevad mitu aastat kestnud uurimistööl ning välitöödel. "Metsast leitud kirik" on seni ilmunud samalaadsetest paikkondlikest väljaannetest kõige põhjalikum, varustatud üksikasjalike kaartidega ning rikkalike illustratsioonidega. Töö on tehtud suure pühendumusega ning tulemus väärib tunnustust nii põneva sisu kui väga kauni kujunduse poolest. Kohapärimuse töörühma juhi Mari-Ann Remmeli teos esitab autori sünnikoha pärimust, milles arhiivitekstidega vahelduvad neid mõtestavad ja analüüsivad põhjalikud kommentaarid. Andreas Kalkuni kaitstud doktoritöö "Seto laul eesti folkloristika ajaloos. Lisandusi representatsiooniloole" on selle oponendi professor Tiina Kirsi hinnangul "säravalt kirjutatud, elavalt ja teravalt mõtestatud, sügavapõhjaline monograafiline dissertatsioon, mis uurib eesti folkloristika ajalugu seto laulu - eriti improvisatsioonilise laulu - kaudu".

Rahvaluulearhiivi teabematerjalide kogum oli 2011. aastal erakordne: arhiiv sai hoiule läbi Eesti tantsinud projekti Teatetants 2011 käigus edasiantud teatepulgad ehk ligi 200 "mälupulka", millele on jäädvustatud projektis osalenud tantsukollektiivide ajalugu, traditsioonid ja kombed koos fotode ja videomaterjaliga.

Kõigile Eesti Kirjandusmuuseumi arhiividega osakondadele sai aasta lõpus osaks ametlik tunnustus Haridus- ja Teadusministeeriumi poolt: teaduskollektsioonide perioodiline hindamine läbiti positiivselt eeskujulikule hindele.

Folkloristika osakond paistis ka 2011. aastal silma elava rahvusvahelise teadustööga, lisaks lisandus 3 doktorikraadi. Liisi Laineste eestvõtmisel toimus augustis Rahvusvahelise Huumoriseltsi Suvekool, koostöö oli vilgas üleeuroopaliste töörühmade raames eriti Eesti-Poola ja Eesti-Bulgaaria ühisprojektides. Ilmumist alus- 
tas rahvusvahelise uurimisrühma "Charms, Charmers and Charming” ajakiri Incantatio. Väljaannetest pälvisid Folklore ja Mäetagused EIRIH-i kõrge kategooria. Ühtlasi tegeldi usinalt teaduse populariseerimisega: Eesti raamatumüügi edetabelite esikümnesse jõudsid Piret Voolaiu "Jänes hüppab kitse" ja Mare Kõiva koostatud "Eesti loitsud".

Etnomusikoloogia osakonna aasta jooksul tehtud tööst väärib kõige enam tunnustust Triinu Ojamaa mahukas monograafia "60 aastat eesti koorilaulu multikultuurses Torontos”, mis laiemalt võttes on üks väike kild pagulaseesti ajaloost. Lõpule jõudis ka Taive Särje ja Aune Valgu ühisuurimus, mis käsitleb musikoloogilisest ja sotsiaalpsühholoogilisest aspektist muusika ja identiteedi vastastoimet Setumaal, kõrvutades seda Eesti teiste piirkondadega.

Olulise sündmusena Eesti Kirjandusmuuseumi tegevuses ja arengus algas 1 . septembril juurdeehituse rajamine, mille tulemusena valmib 2012. aasta suveks 2800 ruutmeetrit valdavalt eritingimustega hoidla- ja laboripinda. Hoone projekti autor on arhitekt Indrek Saarepera ja Amhold AS, ehitustöid teostab AS Rand ja Tuulberg, omanikujärelevalvet Vealeidja OÜ, projekti haldab Riigi Kinnisvara AS. 


\section{Eesti kirjandusmuuseumi sündmuste kroonika 2011}

Krista Ojasaar, Kadri Tüür, Moon Meier

\section{5. oktoober 2010 - 31. jaanuar 2011}

Eesti Kirjandusmuuseumi folkloristika osakond ja Eesti Rahvaluule Arhiiv korraldasid lasteaiapärimuse kogumise aktsiooni, millest võtsid osa õpetajad ja kasvatajad lasteaedadest üle Eesti.

21. jaanuar - 27. märts

Eesti Kultuuriloolise Arhiivi korraldusel leidis aset Vello Paluoja pastellmaalide näitus "Inimesi Eesti kultuuriloos I-II" kirjandusmuuseumi saalis.

27. jaanuar

Akadeemilise Rahvaluule Seltsi ettekandekoosolekul "Püha maa õhtu” jagas Tuuli Otsus oma reisimuljeid Iisraelist.

28. jaanuar

Anu Korb pälvis Eesti Kultuurkapitali rahvakultuuri aastapreemia Siberi eestlaste rahvapärimuse pikaajalise kogumise ja uurimise ning sariväljaande "Eesti asundused I-V" koostamise eest.

10. veebruar - 15 . aprill

Näitus " 25 kauneimat Eesti raamatut ja 5 kauneimat Eesti lasteraamatut" arhiivraamatukogu vitriinides. Näitusel olid eksponeeritud Eesti Rahvusraamatukogu, Eesti Kujundusgraafikute 
Liidu ja Eesti Kirjastuste Liidu korraldatud Eesti raamatukunsti 2010. a. konkursi võidutööd.

\section{3. ja 4. veebruar}

Eesti Kirjandusmuuseumi folkloristika osakonna peakorraldamisel toimunud folkloristide 6. talvekonverentsil "Haldjas 15: Pärimus ja Internet” kõnelesid Aado Lintrop, Lina Gergova, Ell Vahtramäe, Tiiu Jaago, Kadri Tüür, Asta Õim, Mare Kõiva, Ingrid Rüütel, Reet Hiiemäe Maili Pilt, Mare Kalda, Anneli Baran, Liisi Laineste, Piret Voolaid. Posterettekandega esines Sille Kapper. Esitleti Ingrid Rüütli Kihnu tantsude DVD-d, Õie Pärtli ja Esti Koppeli Saaremaa rahvalaulude veebikogumikku "Söit, söit, söit Sörve poole" ja Piret Paali raamatut "Written Cancer Narratives - An Ethnomedical Study of Cancer Patients' Thoughts, Emotions and Experiences". Ühtlasi tähistati viieteistkümne aasta täitumist folklooriserveri haldjas.ee käivitamisest Eestis.

\section{1. märts}

Eesti Kirjandusmuuseum ning Eesti Rahvatantsu ja Rahvamuusika Selts sõlmisid koostööleppe TeateTantsu projekti raames rahvatantsurühmade pärimuse kogumiseks ja talletamiseks Eesti Rahvaluule Arhiivis.

\section{1. märts}

Eesti Kirjandusmuuseumi Eesti Rahvaluule Arhiiv ja Võru Instituut esitlesid Võru Instituudis Urvaste kihelkonna kohapärimuse kogumikku "Metsast leitud kirik / Mõtsast löütü kerik. Urvastõ kohapärimus". Kohapärimusest ja raamatu valmimisest rääkisid kogumiku koostaja Valdo Valper ning Eesti Rahvaluule Arhiivi vanemteadur Mall Hiiemäe. Lauludega astusid üles Jaan Pulk ja Jan Rahman. 


\section{4. märts}

Eesti Vabariigi president Toomas Hendrik Ilves andis üle 2010. aasta rahvaluule kogumispreemiad Maire Salale, Ellen Randojale ja Anni Oraveerile ning avaldas pikaajalise kogumistöö eest tänu Tallinna Ülikooli emeriitprofessorile Pille Kipparile.

\section{0. märts}

EKLA korraldatud ettekandepäeval "Villem Reiman 150" kõnelesid Tarmo Piir, Ants Tooming ja Kristi Metste. Näitust "Villem Reiman 150" (eksponeeriti 30. märts - 15. mai) Eesti Kultuuriloolise Arhiivi materjalide põhjal tutvustas Vilve Asmer. Esitleti Friedrich Robert Faehlmanni “Teoste” 3. köidet.

\section{7. ja 28. aprill}

Eesti Rahva Muuseumi ja Eesti Rahvaluule Arhiivi traditsioonilise noorte etnoloogide ja folkloristide konverentsi "Noorte hääled" peakorraldajaks oli Ave Tupits. Kirjandusmuuseumi uurijatest pidasid ettekanded Katre Kikas ja Jaanika Hunt. Esitleti artiklikogumikku "Pro Folkloristica XVI. Kuldkalake".

\section{9. aprill}

Tartu Ülikooli ja Eesti Kirjandusmuuseumi koostööna toimunud sümpoosionil “Merilai tähendus: Arne Merilai 50” võtsid sõna Berk Vaher, Maia Tammjärv, Janika Kronberg, Hasso Krull, Neeme Lopp ja Anneli Saro. Esitleti Arne Merilai artiklikogu “Õnne tähendus: kriitilisi emotsioone 1990-2010”.

\section{5.-7. mai}

Folkloristikaosakonna ja ERA initsiatiivil võttis Eesti Kirjandusmuuseum teist korda osa Prima Vista kirjandusfestivali raamatumüügist.

\section{3. mai}

Eesti Kirjandusmuuseumi kultuuri- ja kirjandusteooria töörühm korraldas Tartu Kirjanduse Maja krüptis konverentsi "Eshatoloogia ja apokalüpsis: konverents representat- 
siooni piiridest”. Ettekanded pidasid Neeme Lopp, Tõnis Kahu, Jaak Tomberg, Bruno Mölder, Toomas Lott, Leo Luks, Meelis Friedenthal, Hent Kalmo ja Hasso Krull. Esitleti Jaak Tombergi raamatut "Kirjanduse lepitav otstarve".

\section{4. mai}

Muuseumiööl “Öös on aardeid!” toimusid lasteprogrammi üritused, aardeteemaliste rahvalaulude laulmine, aardeotsimismäng, ringkäik Lilla Daami saatel. Tutvustati ja näidati Madis Arukase filmi "Kalitkadega sina peale". Torupillilugudega esines Kalle Sõber, regilaulutöötlusi esitas noorteansambel "Sireli”. Uku Masingu artiklikogumikku "Aarded tellistes" esitlesid Hando Runnel, Mari-Liis Tammiste, Risto Järv ja Kristi Salve. Vaadata võis spetsiaalset näitust "Aardeleide arhiivraamatukogust”, tekste eesti aardejuttudest ning Mare Kõiva ja Andres Kuperjanovi slaidiprogrammi "Kaitseesemed öös".

\section{4. mai - 22. september}

Mari-Ann Remmeli maalinäitus "Ööloomad ja päevalilled" trepigaleriis.

\section{8.-20. mai}

Tallinna Ülikoolis toimunud Eesti Humanitaarinstituudi ja Eesti Kirjandusmuuseumi korraldatud rahvusvahelise IABA konverentsi "Trajectories of (Be)longing: Europe in Life Writing” korraldaja kirjandusmuuseumi poolt oli Leena KurvetKäosaar, assisteeris Maarja Hollo. Kirjandusmuuseumi uurijatest esinesid ettekandega Rutt Hinrikus, Eve Annuk ja Tiina Kirss.

\section{4. mai}

Marin Laagi ja EKLA peakorraldamisel toimunud konverentsil "Muusad ja marionetid: Arno Vihalemm 100" esinesid Andres Ehin, Arne Merilai, Maia Tammjärv, Ene Asu-Õunas, Reet Mark, Janika Kronberg, Sirje Olesk ja Helga Nõu. Avati Marin Laagi ja Vilve Asmeri koostatud Arno Vihalemma juubeli- 
näitus, esitleti Joel Sanga koostatud A. Vihalemma "Kogutud luulet", vaadata sai Enn Nõu filmikaadreid "Ystadis, Vihalemma pool". Muusikat tegi kammerkoor MASK.

\section{4. mai -9. september}

Näitus "Muusad ja marionetid: Arno Vihalemm 100" kirjandusmuuseumi saalis.

\section{7. juuni}

Eesti Kirjandusmuuseumi ja ühenduse Eesti Elulood korraldatud eluloopäeval (peakorraldaja Rutt Hinrikus) meenutati 70 aasta eest toimunud juuniküüditamist ja järgnenud sõja-aastaid. Kõnelesid Imbi Paju ja Aigi Rahi-Tamm. Vaadati Terje Anepaio filmi "Meie mäletame! Meie mälestame!”, esitleti elulooraamatuid "Sõjas kasvanud poisid" ja ingliskeelset "Mälu sõdurid" ning ajakirja Methis nõukogude aega analüüsivat erinumbrit.

\section{5.-20. august}

Eesti Kirjandusmuuseumi (peakorraldaja Liisi Laineste) ja Zürichi Ülikooli korraldatud rahvusvahelises huumori suvekoolis "International Summerschool and Symposium for Humour and Laughter: Theory, Research and Applications" (ISS11) esines kirjandusmuuseumi uurijatest Arvo Krikmann.

\section{6. ja 27. august}

Nüpli I suvekool "Kaotatud klassika: lähilugemine" tõi taas kokku kirjandusuurijad Eesti Kirjandusmuuseumist ja mujalt. Ettekannetega esinesid Pille-Riin Larm, Brita Melts, Janika Kronberg, Erika Renel, Elo Lindsalu, Johanna Ross, Aare Pilv, Kadri Tüür, Tiit Hennoste, Ivo Heinloo, Katre Talviste, Tiina Sulg, Mihkel Kunnus, Maia Tammjärv, Epp Annus. Kultuuriprogrammi sisustasid Hasso Krull ja Carolina Pihelgas. Toimus väljasõit Palanumäele. 


\section{4. september - 31. oktoober}

Vello Paluoja pastellmaalide näitus "Inimesi Eesti kultuuriloos III" kirjandusmuuseumi saalis.

\section{6. september}

Eesti Kirjandusmuuseumi kultuuri- ja kirjandusteooria töörühm korraldas koostöös Eesti Kirjanike Liiduga konverentsi "Võlus ja vaimus, valguses ja varjus" Mari Saadi loomingust. Kõnelesid Epp Annus, Luule Epner, Ele Süvalep, Johanna Ross, Barbi Pilvre, Paula Randver ja Märt Väljataga. Esitleti artiklikogu "Luhtatulek. Ekslemisi Mehis Heinsaare tihnikutes" ("Etüüde nüüdiskultuurist 3", koostaja Sven Vabar, Eesti Kirjandusmuuseumi kultuuri- ja kirjandusteooria töörühm).

\section{3. september}

ERA aastapäeva (24. september) tähistamine küünalde süütamisega endiste töötajate haudadel Raadi ja Pauluse kalmistutel.

\section{3. september}

Teadlaste Ööl (peakorraldaja Astrid Tuisk) toimusid lasteprogramm ning Reet Hiiemäe, Janika Kronbergi ja Kadri Tüüri avalikud loengud, avati Mare Kõiva ja Andres Kuperjanovi fotonäitus "Surva".

\section{3. september 2011 - 17. mai 2012}

Mare Kõiva ja Andres Kuperjanovi fotonäitus "Surva” Perniku (Bulgaaria) rahvusvahelisest maskeerimisfestivalist kirjandusmuuseumi trepigaleriis.

\section{8. oktoober}

Eesti Kirjandusmuuseumi ja Tartu Ülikooli muinasjuttude uurimise töörühma seminar "Seto muinasjutud ja Lutsimaa pühakud" Obinitsa Seto Muuseumitarõs. ERA ja muinasjuttude uurimise töörühma poolt esinesid Moon Meier, Andreas Kalkun, Risto Järv, Mairi Kaasik, Kärri Toomeos-Orglaan ja 
Inge Annom. Esitleti veebiväljaannet "Pühakud ja vägimehed. Muinasjutte Lutsi maarahvalt ja nende naabritelt".

\section{1. oktoober}

KUMU kunstimuuseumis toimunud "Kalevipoja" ingliskeelse uustõlke "Kalevipoeg: the Estonian National Epic / eesti rahvuseepos" pidulikul esitlusel võtsid sõna Eesti Vabariigi president Toomas Hendrik Ilves, Sirje Helme, Janika Kronberg, Arvi Vainomäe, Marin Laak ja Kersti Koll. Musitseeris ansambel Una Corda, "Kalevipoja” tekste luges näitleja Katariina Unt.

\section{4. oktoober - 25. november}

Näitus “Täheke 50" kirjandusmuuseumi saalis.

\section{7. oktoober}

Eesti Kirjandusmuuseumi juurdeehitusele pandi nurgakivi.

\section{0. ja 11. november}

ERA töötajad välitöödeseminaril "Kenttätutkimuksenja keruun haasteet tämän päivän perinteentutkimuksessa" Joensuus. Seminari korraldajad Ida-Soome Ülikool, SKS-i rahvaluulearhiiv ja Joensuu pärimusarhiiv. Ettekandega esines Risto Järv. Lisaks tutvuti põhjalikult SKS-i rahvaluulearhiivi Joensuu osakonnaga (Joensuun perinnearkisto).

\section{7. ja 18. november}

Haridus- ja Teadusministeeriumi, Eesti Rahva Muuseumi, Eesti Kirjandusmuuseumi, Eesti Rahva Muuseumi Sõprade Seltsi ja Emakeele Seltsi korraldatud eesti keele koolitusseminaril "A-B, hakka pähe! Kui ei hakka, lükkan takka!" lasteaiaõpetajatele esinesid kirjandusmuuseumi uurijatest Asta Õim, Piret Voolaid, Astrid Tuisk, Eda Kalmre, Janika Oras, Kärri Toomeos-Orglaan. Viidi läbi ekskursioonid Eesti Kirjandusmuuseumi kogudesse, Eesti Rahva Muuseumi näitustemajja ja Teaduskeskusesse AHHAA, tutvustati Eesti Kirjandusmuuseumi elektroonilisi andmebaase. 


\section{1. november}

Tähistati 90 aasta möödumist Eesti Bibliograafia Asutise loomisest.

\section{8. november}

8. rahvusvahelisel Medica konverentsil "Medical Pluralism in the Era of Digimodernism" esinesid kirjandusmuuseumi uurijatest Renata Sõukand, Raivo Kalle, Mare Kõiva, Piret Paal ja Ave Tupits.

\section{9. ja 30. november}

Eesti Kirjandusmuuseum, Tartu Ülikooli kultuuriteaduste ja kunstide instituut ning Kultuuriteooria tippkeskus korraldasid rahvusvahelise maailma eeposte uurimisele keskendunud sümpoosioni "Traditional and Literary Epics of the World: Textuality, Autorship, Identity. The Kalevipoeg 150”. Peakorraldajaks oli Marin Laak. Kirjandusmuuseumi uurijatest esinesid ettekannetega Tiina Kirss, Mari Sarv, Marin Laak, Risto Järv, Mare Kõiva, Katre Kikas ja Pille-Riin Larm.

\section{1. ja 22. detsember}

55. Kreutzwaldi päevade teaduslikul konverentsil esinesid Janika Kronberg, Toomas Kiho, Peeter Torop, Jaan Kaplinski, Anne Lange, Marin Laak, Kärt Summatavet, Vello Paatsi, Andreas Kalkun, Reet Hiiemäe, Märt Läänemets, Vladimir Sazonov, Heinike Heinsoo, Enn Ernits, Sirje Kupp-Sazonov, Renata Sõukand, Raivo Kalle, Mare Kõiva ja Anu Korb. Konverentsil esitleti ka uusi väljaandeid ning tutvustati "Kalevipoja" juubelinäitust. 


\section{Arhiivraamatukogu}

\section{Merike Kiipus}

2011. aastal kuulusid arhiivraamatukogu (AR) koosseisu: juhataja Merike Kiipus, pearaamatukoguhoidja Ave Pill, vanemraamatukoguhoidjad Dea Kruuse, Kristin Liba, Imbi Pelkonen, Hanna Väli, Ülvi Kalpus, restauraatorid Sigrid Vooremäe, Tiiu Lepasepp, mikrofilmija Kaja Marga (0,5) ja köitja Jaanus Tordik. Seoses kahe vanemraamatukoguhoidja lapsehoolduspuhkusega jätkasid nende ajutiste asetäitjatena Mariliis Õunapuu $(0,5)$, Kerli Puna $(0,25)$ ja Siiri Reinola $(0,25)$. Ajutiste asetäitjatena töötasid ka Maarja Soonberg (3 kuud), Evelin Arust (2 kuud) ja Heino Räim (3 kuud). Koosseisuvälise projektijuhina jätkas Kadri Tüür.

Arhiivraamatukogu finantseeriti Haridus- ja Teadusministeeriumi humanitaar- ja loodusteaduslike kogude rahvuskollektsioonide eelarvest, riiklikest programmidest "Eesti keel ja kultuurimälu" (projekt "Vanem eestikeelne ajakirjandus kui rahvusliku kultuurimälu kandja digitaalajastul") ja rahvuskaaslaste programmist (projekt "Baltica/estica trükimaterjalide arhiveerimine ja kättesaadavaks tegemine"). Rahvusteavikute järelkomplekteerimiseks eraldati vahendeid HTMi teadus- ja arhiivraamatukogude komplekteerimissummadest. Raamatukogu tegevust toetati ka kirjandusmuuseumi infrastruktuuri eelarvest.

2011. aastal jätkus EL struktuuritoetuste poolt finantseeritav projekt "Eesti trükise Punase Raamatu ja eesti kultuuri käsikirjaliste alliktekstide säilivuse ja kättesaadavuse tagamine".

2011. a. tähtsündmuseks oli uue juurdeehituse alustamine. Sellele pandi nurgakivi 27. oktoobril. 2012. a. I poolaastal peab arhiivraamatukogu uude hoidlakorpusesse kolima 3200 laudimeetrit 
trükiseid, mis paiknevad 1894. a. ehitatud aadlielamu keldrites ja tubades, mis on küll ümber kohandatud hoidlateks, kuid ei vasta säilitusnõuetele.

\section{Teadustöö ja publikatsioonid}

Arhiivraamatukogus jätkusid vanema eestikeelse raamatu- ja perioodikafondi, baltica fondi, ÕESi ja erikogude uuringud. Uurimistulemusi rakendati trükiste kirjeldamisel, järelkomplekteerimisel, restaureerimisel/konserveerimisel ning vanema ajakirjanduse tagatis- ja kasutusfondi loomisel. Lisaks põhifondile töötati ka reservfondi trükistega. ARile vajalikud eksemplarid võeti arvele põhifondi ning mittevajalikud eksemplarid eraldati põhiliselt Eesti Hoiuraamatukogule ja Eesti Rahvusraamatukogule.

Jätkati tööd eesti rahvusbibliograafia (1918-1944) koostamisel. Elektronkataloogis ESTER kataloogiti 903 trükist, mille bibliokirjed edastati Eesti Rahvusraamatukogule valikute tegemiseks Eesti Rahvusbibliograafia Andmebaasi (ERB - http://erb.nlib.ee/). Nimetatud perioodist lisati Tartu andmebaasi 904 eksemplarikirjet. Tartu andmebaasis parandati ja täiendati 1057 bibliokirjet.

Jaanuari algul ilmus kirjandusmuuseumi "Kalender 2011/2012" millesse tehti valik ARi digiteerimisprojekti kaheksast ainueksemplarist. Avaldati 6 ülevaadet ja kirjutist raamatukogu tegevuse kohta.

\section{Seminarid, ettekanded, juhendamised, koolitused, töörühmad}

\section{Korraldatud seminarid}

4. veebruar - Kultuuriteooria tippkeskuse doktorikool kirjandusmuuseumis "Workshop Cultural memory and the archive: selection, conservation, transformation / Group work, group: Old publications and rarities" - K. Tüür, A. Pill. 
15. märts - Eriseminar baltisaksa keelest ja kultuurist kirjandusmuuseumis - I. Pelkonen.

26.-30. juuni - BaltHerNeti suvekool Käärikul - M. Kiipus.

8.-10. juuli - Digiprojekti mõttetalgud Muhus - K. Tüür, M. Kiipus, A. Pill.

Peaaegu igal nädalal viidi kirjandusmuuseumis läbi projekti "Eesti trükise Punase Raamatu ja eesti kultuuri käsikirjaliste alliktekstide säilivuse ja kättesaadavuse tagamine" tarkvaraarenduse töörühma koosolekuid - K. Tüür.

\section{Ettekanded}

25. märts - ERÜ maaraamatukogude sektsiooni teabepäev rahvusraamatukogus. - K. Tüür "Kirjandusmuuseumi virtuaalne kelder". 6. aprill - Tallinna Ülikooli Akadeemilise Raamatukogu 65. aastapäeva teaduskonverents "Ülikooli raamatukogu 21. sajandi künnisel". - M. Kiipus "Eesti trükise punase raamatu roheline tee".

30. juuli - Kodavere murdepäev. - K. Tüür "Muhu murde kirjutamisest".

30.-31. august - Eesti mäluasutuste suveseminar "Digitaalse ressursi strateegiad ja kompetentsikeskused” Palmses. - K. Tüür, M. Sarv "Digitaalsest kultuuripärandist Eesti Kirjandusmuuseumis". 23. september - teadlaste öö kirjandusmuuseumis. - K. Tüür "Vanad trükised riiulil ja ekraanil".

\section{Juhendamised}

Julika Põder'i (Tartu Kõrgem Kunstikool) lõputöö ““"Eesti- Ma Rahwa Koddo- ja Kirko Ramat”, selle sisuploki restaureerimine ja säilitusköite valmistamine" osaline juhendamine - M. Kiipus. Lõputöö tulemusena restaureeriti arhiivraamatukogu 1758. a. eksemplar (A 7954).

Tartu Kõrgema Kunstikooliga tehti koostööd vanemate trükiste restaureerimisel/konserveerimisel - I. Pelkonen.

TÜ magistrantide (Evelin Arust, Maarja Soonberg) arhiivindusliku praktika juhendamine - A. Pill, Ü. Kalpus. 


\section{Koolitused, seminarid}

26.-27. jaanuar - digiteerimise koolitus TÜR-is - "Digitaalne säilitamine - mida sellest peaks teadma?” - K. Liba, M. Ounapuu, M. Kiipus.

2.-3. märts - teadusraamatukogude talveseminar Otepääl - M. Kiipus.

30.-31. august - Eesti mäluasutuste suveseminar "Digitaalse ressursi strateegiad ja kompetentsikeskused” Palmses - K. Tüür, M. Kiipus.

5.-6. september - riigihangete koolitus - K. Tüür, M. Kiipus.

30 . september - 1 . oktoober - rahvuskaaslaste II konverents rahvusraamatukogus - M. Kiipus.

5. oktoober - Creative commons'i seminar kirjandusmuuseumis K. Tüür, M. Kiipus.

19. detsember - Rahvusarhiivi arhiivitarkvara tutvustusseminar K. Tüür, M. Kiipus.

\section{Töörühmad}

Merike Kiipus võttis osa Haridus- ja Teadusministeeriumi humanitaar- ja loodusteaduslike teaduskollektsioonide ekspertnõukogu, ELNET Konsortsiumi juhatuse, Fr. Puksoo auhindamiskomisjoni tööst, ERÜ kogude toimkonna, MTÜ Baltic Heritage Network ning ELNET Konsortsiumi digiteerimise ja mikrofilmimise töörühma tegevusest. Kerli Puna osales ELNET Konsotsiumi liigitamise- ja märksõnastamise ning kataloogimise töörühmas, Ave Pill ELNET Konsortsiumi perioodika ja teenuste töörühmas ja ERÜ vanaraamatu toimkonna töös, Kristin Liba ELNET Konsortsiumi tehnilises töörühmas ja ERÜ kogude toimkonnas, Helje Laas ELNET Konsortsiumi analüütika töörühmas ja ERÜ Tartu toimkonna töös, Ülvi Kalpus ERÜ vanaraamatu toimkonna töös, Imbi Pelkonen ÕESi ja Baltisaksa Kultuuriseltsi tegevuses, Sigrid Vooremäe Tartu Restauraatorite Klubis. 


\section{Näitused}

\section{Kirjandusmuuseumis}

10. veebruar - avati koridorinäitus " 25 kaunimat raamatut" (K. Liba, M. Õunapuu).

21. veebruar - mälestusraamatute näitus elulookoolitusel muuseumi saalis (A. Pill).

30. märts - 15. mai - koostöönäitus EKLAga "Villem Reiman" (A. Pill, K. Liba).

19. aprill - eksponeeriti raamatukokku saabunud võõrkeelset kirjandust (K. Liba, I. Pelkonen).

13. mai - muuseumiöö näitus "Aardeleide arhiivraamatukogust", mis valmis peaaegu terve kollektiivi osavõtul.

8. september - eksponeeriti uuemat võõrkeelset kirjandust (K. Liba, I. Pelkonen).

21. detsember - avati koridorinäitus "Kalevipoeg inspireerib" ja koostöönäitus EKLAga "Kalevipoeg 150: kingitus Eestile” (A. Pill, I. Pelkonen).

\section{Arhiivraamatukogu materjalide kasutamine väljaspool kirjan- dusmuuseumi}

Näitused ERM-is: “Jüri Linnus” (jaanuar), “Teerajaja: Villem Reiman 150" (24. veebruar - 25. märts), "Kartul - meie teine leib, aga mitte ainult" (11. aprill - 20. mai), "Meie elu lugu: 70 aastat juuniküüditamisest” (8. juuni - 6. august), "Mitä uuttaa kuuluu? Keeleteadlane Paula Palmeos 100" (17. november - 31. jaanuar 2012). Tartu Ülikooli Ajaloomuuseumis korraldati näitus "Kalevipoja tõlked" (29.-30. november).

Tehti koostööd ERMiga uue ekspositsiooni vanaraamatu keelenäidete ja ajakirjanduse osa kujundamisel.

\section{Komplekteerimine}

Arhiivraamatukogu fonde täiendati peamiselt sundeksemplaride baasil. Aktiivselt tegeldi ka järelkomplekteerimisega ning osaleti mitmetel raamatuoksjonitel (A. Pill, K. Liba, I. Pelkonen). Arvele 
võeti 26888 eksemplari (sundeksemplarid, annetused, vahetus, ostud, reservfond).

2011. a. võeti rohkesti vastu annetusi üksikannetajatelt: Liivi Aarma, Viktor Boikov, Turid Farbregd, Michael Gallmeister, Rutt Hinrikus, Maris Jaagosild, Ivar Jõks, Anne Järvpõld, Raivo Kalle, Ülvi Kalpus, Aldo Kals, Stella Karolin, Heino Kasesalu, Harri Kask, Valev Kaska, Margus Kasterpalu, Kyösti Kettunen, Elle-Vaike Kiik, Dave Kiil, Taivo Kirm, Janika Kronberg, Dea Kruuse, Ott Kurs, Marin Laak, Juhan Lepasaar, Daniel Ling, Mihkel Loodus, Vello Lään, Helle Maaslieb, Veronika Mahtina, Jaan Malin, Heino Mardiste, Helle Metslang, Lui Niilo, Tõnis Nõmmik, Enn Nõu, Leida Oeselg, Vello Paatsi, Hillar Palamets, Erast Parmasto, Imbi Pelkonen, Arno-Toomas Pihlak, Lauri Pilter, Anneli Porri, Aino Praakli, Jael Puusaag, Heiki Raudla, Heino Räim, Kristi Salve, Lauri Sommer, Terje Soots, Renata Sõukand, Jüri Talvet, Tiina Tamman, Villu Tari, Lille Teedumäe, Imbi Tomberg, Szilard Tóth, Kadri Tüür, Eve Vahtra, Triinu Varik, Tõnu Vessmann, Helle Virt, Larissa Volpert, Aino Voltri ja Tarah M. Xaintorxare.

Raivo Adlas andis üle raamatuid Endla Hermanni pärandist. Trükiseid käidi valimas Leo Metsari pärandi hulgast.

Annetusi saadi asutustelt ja organisatsioonidelt: Adelaide'i Eesti Selts, AS Ajakirjade Kirjastus, Association of Finnish Ethnologists, Baltic Defence College, E-Kunstisalong, Eesti Apostlik-Õigeusu Kirik, Eesti Arengufond, Eesti Arhiiv Austraalias, Eesti Hoiuraamatukogu, Eesti Kirik, Eesti Kirjanike Liit, Eesti Koostöö Kogu, Eesti Kunstiakadeemia, Eesti Paeliit, Eesti Rahva Muuseum, Eesti Rahvusraamatukogu, Eesti Skautide Ühing, Eesti Spordimuuseum, Eesti Vabagraafikute Ühendus, Eestikeelne kogudusetöö Soomes, Folklore Fellows, Goethe Instituut, Haridus- ja Teadusministeerium, Hiidlaste Selts (Torontos), Hõimurahvaste Programm, Juminda Külaselts, Jõgeva Maavalitsus, Kaitseväe Ühendatud Õppeasutused, Keila Kool, Keskkonnaministeerium, Kiidjärve Küla Selts, Kindlustuse Muuseum, Kristiine Kaubanduskeskus, Kultuuriministeerium, Minnesota Eesti Selts, Märjamaa Gümnaasium, Narva Noortekeskus, The Nordic Press Inc, Politsei- ja Piirivalveamet, Portlandi Eesti Selts, Põllumajandusministeerium, 
Põlva Lasteaed “Mesimumm”, Põlva Muusikakool, Riigikogu Kantselei, Riigikontroll, Riigimetsa Majandamise Keskus, Rootsi Eestlaste Liit, Ropka-Karlova Päevakeskus, Seattle'i Eesti Selts, Soome Instituut, Sotsiaal-Humanitaarinstituut, Supilinna Selts, Tallinna Haridusamet, Tallinna Kiirabi, Tallinna Reaalkool, Tallinna Tehnikaülikooli Geoloogia Instituut, Tallinna Tehnikaülikooli Kuressaare Kolledž, Tallinna Ülikooli Haapsalu Kolledž, Tartu Kõrgem Kunstikool, Tartu Linnaraamatukogu, Tartu Nefa Rühm, Tartu Õpetajate Seminari Raamatukogu, Tartu Ärinõuandla, Tartu Ülikooli raamatukogu, Tartu Ülikooli sotsiaalteaduskonna raamatukogu, Tarvastu Vallavalitsus, Tuglas-Seura, Uppsala Universitet, Valga Keskraamatukogu, Valga Põhikool, Vana-Vigala Tehnika- ja Teeninduskool, Vancouveri Eesti Selts, Vanemuise Selts ja Vene Uurimiskeskus Eestis.

Eriti tuleb tunnustada Kalju Tammaru tegevust fondide järelkomplekteerimisel, kes Eesti Hoiuraamatukogu peavarahoidjana on püsivalt varustanud arhiivraamatukogu seni puuduvate nimetustega.

Suurimaks vahetuspartneriks oli Soome Teaduskirjanduse Vahetuskeskus.

\section{Andmebaasid}

\section{Elektronkataloog ESTER (http://tartu.ester.ee/)}

Elektronkataloogis ESTER inventeeriti 26888 eksemplari. Raamatufondi juurdekasv: 8419 raamatut, 1546 jätkväljaannet, 100 nooti, 15 makkaarti, 4 masinloetavat teavikut (inventeerija K. Liba).

Perioodikafondi juurdekasv: 1790 aastakäiku, neist eestikeelseid 1488 ja võõrkeelseid 302 aastakäiku (inventeerija A. Pill).

Pisitrükiste juurdekasv: 15014 pisitrükist (inventeerija H. Väli).

Eestikeelseid raamatuid kohaviidastas ja töötles M. Ounapuu, võõrkeelseid raamatuid I. Pelkonen. Kokku töödeldi 7000 eesti- ja võõrkeelset raamatut. Raamatuid kataloogisid, märksõnastasid ja liigitasid S. Reinola, D. Kruuse ja K. Puna (903 bibliokirjet). Jätkati kaartkataloogide retrokonverteerimist (E. Arust, D. Kruuse, Ü. 
Kalpus, K. Liba, A. Pill, M. Soonberg, M. Õunapuu). Kokku sisestati ca 18000 retrokirjet. Jätkus Tartu andmebaasi eesti raamatu 1918-1944 bibliokirjete redigeerimine ning eksemplarikirjete lisamine (Ü. Kalpus). Andmebaasi kanti 666 eksemplari ning parandusi ja täiendusi tehti 1057 bibliokirjes. Parandused ja täiendused edastati Rahvusraamatukogule.

Elektronkataloogi sisetati kokku 31116 eksemplari. Seisuga 31.12.2011 on kogude suuruseks: 962475 arvestusühikut, millest on kantud elektronkataloogi 554443 ühikut ehk 57,6 \% raamatukogu säilikutest.

\section{Eesti vanema raamatu digitaalne andmebaas (http://www2. kirmus.ee/grafo/)}

Digitaalraamatukogu Grafo liidestati Eesti Kirjandusmuuseumi failirepositooriumiga Kivike. 450 seni Grafos paiknenud trükise pildifailid arhiveeriti Kivikeses. Arendati Grafo olemasolevat keskkonda. Avalehel on nüüd rakendatud otsingut, mille kaudu saab otsida ka märksõnastatud teatmeteoste sisu järgi. Kui varem sai trükiseid alla laadida ühe lehekülje kaupa, siis nüüd on võimalik alla laadida ka raamatu tervikteksti Kivikeses olevate säilikute PID-ide järgi. Säilikute laadimine Grafosse toimub PID-i alusel Kivikese kaudu. Grafos eksponeeritakse põhiliselt kalendrikirjandust, muud digitaalteavikud paigutatakse Kivikesse.

\section{Eesti Kirjandusmuuseumi failirepositoorium Kivike (http:// kivike.kirmus.ee/)}

Koostöös Eesti Rahvaluule Arhiivi ja Eesti Kultuuriloolise Arhiiviga osaleti failirepositooriumi tarkvara arendamisel. Trükiste mooduli uus rakendus on seotud elektronkataloogiga Ester. Kivikesse laaditud digiteeritud säilikute metaandmeid ei pea enam käsitsi sisestama, sest liidestus Estriga on tehtud bibliokirje numbri alusel ja vajalikud metaandmed saadakse automaatselt Estrist. Repositooriumisse Kivike paigutatati 450 trükise arhiivifailid. Repositooriumi sisendalasse on lisatud kõik "Eesti trükise Punase 
Raamatu" digiteeritud eksemplaride failid, mis on lugejatele kättesaadavad digitaalarhiivis Digar.

\section{Memoriaalkogude elektronkataloog (http://www2.kirmus.ee/ memoriaal/)}

Andmebaasi andmestik on 2008. a. tasemel (33467 kirjet). Elektronkataloogis Ester olevad personaalkogude loendid on lingitud memoriaalkogude elektronkataloogi, kus on võimalik neid kogude kaupa lehitseda.

\section{Korraldamine}

2011. aastal alustati seoses juurdeehitusega ulatuslikke kolimistöid. Esimesel korrusel vabastati vanemate memoriaalkogude alt ruum nr 152, mis on projekti järgi planeeritud uueks serveriruumiks. Memoriaalkogud koliti ajutiselt II korruse fondihoidlasse. Järgnevalt vabastati keldrikorrusel ruum nr 057, mis on kavandatud sissetuleva materjali hoidmiseks. Vanemad mikrofilmid (negatiivid ja positiivid) koliti ajutiselt ruumi nr 025. Kahjuks tuli likvideerida raamatukogu 95. a. juubeliks avatud Mart Lepiku tuba, mis jäi nüüd lammutusalasse. B. Alveri ja M. Lepiku personaalkogu koliti III korruse fondihoidlasse ja paigutati ajutistele riiulitele. Kõik kolimistööd viidi läbi $H$. Räime juhtimisel. H. Räime juhendamisel alustati ka vanaraamatu kollektsiooni arhiiveksemplaride ulatuslikku mapistamist.

Korraldustöödena jätkus vanema ja uuema perioodikafondi ajalehtede ja ajakirjade aastakäikude mapistamine, kogumite moodustamine ja kirjeldamine (A. Pill). Jätkati ka uuema väiketrükise kogumite moodustamist, mapistamist ja kirjeldamist (H. Väli) ning vanema väiketrükiste kogu süstematiseerimist ja kirjeldamist (S. Reinola).

Jätkati reservfondi trükiste leidumuse võrdlemist põhifondiga. Reservi hulgast saadi lisa nii vanemale raamatufondile kui ka perioodika kogule ja baltica'le. Arhiivraamatukogule mittevajali- 
kud trükised eraldati Eesti Hoiuraamatukogule, Eesti Rahvusraamatukogule, Tallinna Ülikooli Akadeemilisele Raamatukogule jt raamatukogudele. Reservfondi uurimistöödega olid seotud A. Pill ja I. Pelkonen.

Veebruarist alates (60 tundi) viibisid AR-is praktikal TÜ magistrandid Evelin Arust ja Maarja Soonberg, keda juhendasid A. Pill ja Ü. Kalpus. Praktikandid tegelesid põhiliselt memoriaalkogude (Aavik, Eisen, Hurt, Loorits, Roos) elektronkataloogi Ester sisestusega. Mõlemad praktikandid täitsid oma tööülesandeid väga korrektselt ja leidsid II poolaastal raamatukogus ka ajutist tööd nii memoriaalkogude sisestusel kui ka baltica raamatufondi I suuruse eksemplaride sisestamisel ja kolimiseelsel pakkimisel.

\section{Säilitamine}

Kõikide arhiiveksemplaride hoidlate klimaatilisi tingimusi jälgiti ja mõõdeti iga päev, dublettide hoidlates üks kord nädalas. Mõõtmistulemused kanti Exceli tabelitesse (S. Vooremäe).

Vanema raamatufondi arhiiveksemplaride ja perioodikafondi aastakäikude ümbristamiseks valmistati arhiivipüsivast kartongist 766 individuaalmõõtmetes mappi (S. Vooremäe, T. Lepasepp, J. Tordik). Uuemaid ajalehti, ajakirju ja raamatute dublette köideti kohapeal kokku 160 nimetust (J. Tordik). Arhiivipüsivaid mappe telliti osaühingult File-Est ja Maksing OÜ. Köite- ja restaureerimistöödeks osteti vajalikke materjale Saksamaalt. Uuemat perioodikat köideti Mare Fucksi köitekojas ning sealt telliti ka erimõõdulisi mappe.

Tagatis- ja kasutusfondi loomisel tehti säilitusalast koostööd Eesti Rahvusraamatukoguga, Tallinna Ülikooli Akadeemilise Raamatukoguga, Tartu Ülikooli Raamatukoguga ja Eesti Ajalooarhiiviga. 


\section{Restaureerimine}

Baltica ja eesti vanaraamatu fondist restaureeriti/konserveeriti 1 täisnahkköide ("Sioni Laulo-Kannel” 1855), 60 poolnahkköidet ("Ehstnische Wörterbuch" 1780, "Juhhataja Piibli ramato sisse" 1789, "Katekismuse õppetuse seletus" 1851, "Lühhike Piibli Ramat" 1803, "Noodiraamat" 1831, "Wastne Testament” 1821, 1839 jmt.), 137 papp-ja paberköidet, 13348 raamatulehte. Parandati 236 maakaarti, 562 raamatukaant, korrastati ja õmmeldi 267 raamatuplokki, 162 köitel eemaldati roostes klambrid (T. Lepasepp, S. Vooremäe).

Lihtsamaid restaureerimistöid tegid praktika raames Tartu Kõrgema Kunstikooli tudengid Silli Peedoski juhendamisel. Kokku restaureeriti 14 köidet.

Jätkati hävimisohus 19. sajandi ja 20. sajandi alguse ajakirjanduse ettevalmistamist mikrofilmimiseks (eelnev puhastamine, restaureerimine). Mikrofilmimiseks valmistati ette Pernausche Zeitung (1897-1918), Ревельские известия (1893-1900).

\section{Tagatisfond}

Koostöös Eesti Rahvusraamatukoguga ja Tallinna Ülikooli Akadeemilise Raamatukoguga jätkati vanema ajakirjanduse tagatisfondi loomist.

Mikrofilmimiseks valmistati ette (täieliku aastakäigu komplekteerimine, üksiknumbrite leht-leheline kontroll, töölehtede koostamine) ja filmiti vastavalt ISO standarditele: Pernausche Zeitung (1897-1918), Ревельские известия (1893-1900), Verordnungs-Blatt des Kreises Pernau ja Verordnungs-Blatt des Kreises Pernau (1918). Kokku valmis 22 negatiivfilmi (17539 kaadrit), mis ilmutati Eesti Ajalooarhiivis. Mikrofilmimiseks deponeeriti ajalehtede üksiknumbreid ka teistelt raamatukogudelt ja arhiividelt (RR, TLÜAR, Rahvusarhiiv). Eesti Rahvusraamatukogule deponeeriti mikrofilmimiseks XX saj I poole ajalehti ja ajakirju kokku 96 aastakäiku. 


\section{Digiteerimine}

Projekti "Eesti trükise Punase Raamatu ja eesti kultuuri käsikirjaliste alliktekstide säilivuse ja kättesaadavuse tagamine" raames jätkati vanaraamatu kollektsiooni digiteerimiseelset ettevalmistust. Kokku võrreldi ja sisestati elektronkataloogi ESTER 3959 eksemplari (sh 754 ÕESi kollektsioonist). Digiteerimiseks valmistati ette 644 parimat eksemplari, mis paigutati ühtlasi ka happevabadesse ümbristesse. Eesti Rahvusraamatukogus digiteeriti 809 trükist (66388 lehekülge), mis on kättesaadavad ka Eesti kultuuripärandi andmebaasis DIGAR (http://digar.nlib.ee/).

Eesti Ajalooarhiivis skaneeriti 25 mikrofilmirulli (12134) kaadrit XIX ja XX sajandi algupoole rariteetsete ning hävimisohus olevate ajalehtede aastakäikudest. Skaneeritud pildifailid (TIFF) arhiveeriti välistele kõvaketastele ja edastati ka Eesti Rahvusraamatukogu serverisse. Andmebaasi DEA (http://dea.nlib.ee) lugejamoodulis tehti kättesaadavaks 70 mikrofilmirulli ca 60000 pildifaili. Lugejatele on nüüd kättesaadavad: Aiatööleht (1907-1916), Amerika Eesti Postimees (1925-1928), Käsitööleht (1906-1911), Lasteleht (19001940), Naesterahva Töö ja Elu Käsitööleht (1912-1927), Postimees (Pärnu) (1905-1918), Põllumees (1884-1912), Põllutööleht (19061916), Usk ja Elu (1908-1917), Uusleht (1912-1918), Ühistegevusleht (1910-1918) jmt. eesti kultuuriloo olulised väljaanded.

ELNET Konsortsiumi digiteerimise töörühmas osalesid Kadri Tüür ja Merike Kiipus.

\section{Fondide kasutamine}

Aruandeaastal registreeriti 147 uut lugejat, raamatukogul on 1914 lugejat. Arhiivraamatukogu külastati ca 3100 korral, sooritati $c a$ 16500 laenutust, vastati ca 200 elektroonilisele päringule, konsultatsioone anti ka telefoni teel. Kohapeal jagati konsultatsioone ca 900 korral. Korraldati 24 õppeekskursiooni 477 osavõtjale. 
Arhiivraamatukogus käis uurimistööd tegemas 20 uurijat Bulgaaria TAst, Amsterdami Ülikoolist, Budapesti Ülikoolist, Helsingi Ülikoolist, Jyväskylä Ülikoolist, SKSist jm.

Aasta jooksul kasutati andmebaase 303000 korral. Kuna serverite töös oli seoses juurdeehitusega mitmeid katkestusi, on kasutusstatistika väiksem kui varasematel aastatel.

Arhiivraamatukogu trükiseid deponeeriti ajutiselt teistele muuseumidele ja raamatukogudele mikrofilmimiseks, skaneerimiseks ja näitustel eksponeerimiseks.

\section{Koostööpartnerid}

ARi põhilisteks koostööpartneriteks on MTÜ Baltic Heritage Network, Eesti Arhiiv Austraalias, Eesti Arhiiv Ühendriikides, Endel Aruja nimeline arhiiv ja raamatukogu Torontos, Tuglase Selts, Soome Teaduskirjanduse Vahetuskeskus, Eesti Hoiuraamatukogu, Eesti Rahvusarhiiv, Eesti Rahvusraamatukogu, Tallinna Ülikooli Akadeemiline Raamatukogu, Tartu Ülikooli Raamatukogu, Tartu Kõrgem Kunstikool.

\section{Arhiivraamatukogu bibliograafiaosakond}

Arhiivraamatukogu bibliograafiaosakonna koosseisu kuulusid vanembibliograafid Helje Laas, Annemaria Onoper ja bibliograaf Ülle Tamm. Vabatahtlikuna jätkas Jaan Isotamm.

\section{Bibliograafiatöö}

Põhitööna jätkati eesti ajakirjanduse analüütilise retrospektiivse üldise bibliograafia koostamist. Kirjandusmuuseumi kodulehele ja aastaraamatusse koostati muuseumi väljaannete bibliograafia. Osaleti ERÜ ja TLÜ Akadeemilise Raamatukogu Eesti bibliograa- 
fiaväljaannete auhinnakomisjoni ja Fr. Puksoo auhinnakomisjoni töös.

29. septembril tähistati kauaaegse bibliograafi ja juhataja Virve Adamsoni 90. sünnipäeva. Auväärset juubilari auks koostati slaidiprogramm bibliograafide tegemistest läbi aegade. Juubilari tervitas peaaegu kogu muuseumi pere. Kohal oli ka endisi töötajaid.

21. novembril täitus 90 aastat osakonna eelkäija Eesti Bibliograafia Asutise sünnist, mida tähistati kitsamas ringis.

\section{Andmebaasid}

\section{BIBIS}

Jätkati Postimehe $(1936,1937,1938)$ ja Sädemete $(1936,1937,1938)$ aastakäikude bibliografeerimist eesti ajakirjanduse artiklite analüütilises andmebaasis BIBIS (http://www2.kirmus.ee/biblioserver/). Andmebaasis koostati, annoteeriti, liigitati, ja märksõnastati 8480 bibliokirjet. Kokku on kasutajatele leitavad 106304 kirjet (artiklid, arvustused, jutustused, reisikirjad, sõnumid, vested, ülevaated jms). Andmebaasi kirjed on lingitud DEA andmebaasi (http://dea.nlib.ee) ning Postimehe ja Sädemete bibliografeeritud artikleid saab lugeda nimetatud väljaannete vastavatelt lehekülgedelt.

\section{ISIK}

Eesti pseudonüümide andmebaasi ISIK (http://www2.kirmus.ee/ biblioserver/isik/) täiendati biograafiliste andmete osas (isik, tema pseudonüümid, daatumid, tegevusala, lühibiograafia) 600 uue kirjega. Jätkati pseudonüümide avamist ja andmebaasi lisamist bibliograafiate ja teatmeteoste põhjal. Andmebaasist on leitavad üle 7000 isiku pseudonüümid. 


\section{ISE}

ELNET Konsortsiumi poolt koostatava eesti ajakirjanduse artiklite andmebaasi ISE (http://ise.elnet.ee/) lisati Eesti Kirjandusmuuseumi väljaannete põhjal 41 uut kirjet. Bibliokirjed koostati vastavalt MARC juhenditele ja märksõnastati Eesti üldise märksõnastiku alusel. Aktiivselt osaleti ELNET Konsortsiumi andmebaasi ISE analüütilises töörühmas.

\section{Teatmefondi täiendamine ja kasutamine}

Jätkati Jaan Toomla kartoteegi läbivaatamist ja korrastamist (J. Isotamm).

Aasta jooksul külastati andmebaase 303000 korral. Kohapeal teenindati uurijaid 211 korral. E-maili ja telefoni teel vastati 120 teemapäringule. Kanal 2-le valmistati ette Rootsi kroonprintsiga seotud materjale, Eesti Pressimuuseumile anti ajakirjandusajalooga seotud materjale (originaalmaterjali valik ja eraldamine reservfondist, skaneeringute tegemine põhifondi eksemplaride põhjal). Arendati koostööd ERMiga tulevase püsinäituse ajakirjandusega seotud materjalide osas ja MTÜ Ajakirjanduse uurimisja koolituskeskusega näituste valdkonnas. Võeti vastu 16 õppeekskursiooni. 


\section{Eesti Kultuurilooline Arhiiv}

\section{Vilve Asmer}

Eesti Kultuuriloolises Arhiivis jätkati 2011. aastal nii teadus- kui arhiivitööga. Selle koosseisus töötas kaks kultuuri ja kirjanduse uurimise töörühma sihtfinantseeritavate teadusteemadega "Kultuuriloo allikad ja kirjanduse kontekstuaalsus" (kultuuriloo allikate ja kirjandusuurimise töörühm) ning "Mimeesi retoorilised alusmustrid ja eesti tekstikultuur” (kultuuri- ja kirjandusteooria töörühm).

Kultuuriloo allikate ja kirjandusuurimise töörühma täitjatena jätkasid Marin Laak (teemajuht), Eve Annuk, Rutt Hinrikus, Leena Kurvet-Käosaar (koormusega 0,5), Sirje Olesk, Vello Paatsi ja Piret Noorhani (koormusega 0,2); alates septembrist liitusid töögrupiga Külliki Kuusk (koormusega 0,5) ja Maarja Hollo (koormusega 0,5 kuni lapsepuhkusele minekuni oktoobris 2011); toimetajad Kristi Metste ja Tiina Saluvere ning assistent Marju Mikkel (koormusega 0,5). Kultuuri- ja kirjandusteooria koosseisus töötasid Virve Sarapik (teemajuht, koormusega 0,7), Epp Annus, Luule Epner (koormusega 0,5 alates 1.07.2011), Mari Laaniste, Kaia Lehari (koormusega 0,4), Neeme Lopp, Eva Näripea (koormusega 0,5), Katrin Puik (koormusega 0,5 kuni lapsepuhkusele minekuni veebruaris 2011), Jaak Tomberg, Sven-Hannes Vabar (koormusega 0,5) ja Piret Viires (koormusega 0,5).

EKLA arhiivitööga olid seotud arhiivi juhataja Vilve Asmer ning arhivaarid ja assistendid Leili Punga, Johanna Ross (koormusega 0,5) ja Mari Õunapuu (käsikirjade kogu); Elo Maandi (koormusega 0,5) ja Irma Pilt (fotokogu) ning septembrist lapsepuhkuselt tulnud Maarja Savan (heli- ja filmikogu). Pildistamiste, fototellimuste 
täitmise ja digiteerimistöödega tegeles fotograaf Alar Madisson, andmebaasi sisestustöid tegi Joel Ilja.

\section{Teadustöö}

\section{Kultuuriloo allikate ja kirjandusuurimise töörühm}

\section{Teadusprojektid}

2011. aastal jätkus sihtfinantseeritava teadusteema "Kultuuriloo allikad ja kirjanduse kontekstuaalsus" (SF0030065s08, 2008-2013, teemajuht Marin Laak) täitmine. Teema on keskendatud 19. ja 20. sajandi eesti kirjanduskultuuri ja sellega seotud arhiiviallikate uurimisele neljas peamises suunas: biograafika, diasporaa, kontekst ja digitaalne mälu. Diasporaa uurimine ulatus Austraaliasse, eesti diasporaa suhete uurimiseks töötati välja uus Eesti Teadusfondi grandiprojekt "Eesti kirjanduse pingeväljad 1956-1968” (M. Laak, S. Olesk, T. Kirss, J. Kronberg, R. Hinrikus, T. Saluvere, J. Ross, K. Ojasaar jt). Teadustegevust toetasid neli riikliku programmi "Eesti keel ja kultuurimälu" projekti: "Kirjandus- ja kultuuriloolised allikapublikatsioonid EKLA kogudest" (vastutav täitja Eve Annuk), "Eesti elulood kultuurimälu kandjana" (Rutt Hinrikus), "Humanitaarajakirja Methis rahvusvahelise taseme tõstmine" (Marin Laak) ja "Interaktiivne teabekeskkond "Kreutzwaldi sajand. Eesti kultuurilooline veeb"” (Marin Laak). ETF-i grant "Omaeluloolisus eesti kirjandusmaastiku osana” (nr 7354, 2008-2011, grandihoidja Leena Kurvet-Käosaar) toetas Eesti elulugude ja mälestuste andmebaasi ELMA väljatöötamist. 


\section{Konverentside ja teadusürituste korraldamine}

Osaleti kahe rahvusvahelise konverentsi läbiviimisel. 18.-20. mail korraldati koostöös Tallinna Ülikooliga üle-euroopaline autobiograafiauurijate konverents IABA Europe 2011, “Trajectories of (Be)longing: Europe in Life Writing" ("Kuulumise/igatsuse trajektoorid: Euroopa omaelulookirjutuses”), kus oli osavõtjaid 26 riigist. Peakorraldajaks oli Leena Kurvet-Käosaar, assisteeris Maarja Hollo.

Koostöös Tartu Ülikooli kultuuriteaduste ja kunstide instituudi ning Kultuuriteooria tippkeskusega oli Eesti Kirjandusmuuseum üheks 29.-30. novembril aset leidnud rahvusvahelise sümpoosioni "Traditional and Literary Epics of the World: Textuality, Autorship, Identity. The Kalevipoeg 150” korraldajaks. EKLAst kuulus organiseerimistoimkonda Marin Laak.

2. veebruaril korraldas Rutt Hinrikus koolitusseminari "Kuidas koguda mälestusi ja mida nendega teha?", mis oli suunatud ennekõike raamatukogude ja arhiivide töötajatele. Oldi osalised eesti rahvusliku liikumise juhi Villem Reimani 150. sünniaastapäeva tähistamisel, mille puhul toimus 30. märtsil Eesti Kirjandusmuuseumi saalis teemakohane ettekandepäev, korraldajateks Vilve Asmer ja Kristi Metste. Luuletaja, graafiku ja raamatuillustraatori Arno Vihalemma 100. sünniaastapäeva tähistava konverentsi "Marionetid ja maastikud" toimumise eest 24. mail Eesti Kirjandusmuuseumis vastutas Marin Laak. Päevakohaseid ettekandeid oli nii kirjandus- kui kunstiteadlastelt. 17. juunil viis Rutt Hinrikus läbi traditsioonilise iga-aastase eluloopäeva. Elulugude fond EKLA-s on jätkuvalt üks huvipakkuvamaid kogusid ja seda kahepoolselt - nii nende kirjutajatele kui lugejatele-uurijatele. Piret Noorhani korraldatud BaltHerNeti suvekoolis "Eestlaste kultuuripärand võõrsil. IV. Balti eri” 26.-30. juunil Käärikul oli kõne all diasporaa kultuuripärandi kogumine ja säilitamine. Traditsiooniks on saanud iga-aastased Nüpli kevadkoolid Gustav Wulff-Õie majamuuseumis Otepää lähistel. Seekordne kokkusaamine toimus suve lõpul, 26.-27. augustil Nüpli 1. kirjanduse suvekooli nimetuse 
all teemal "Kaotatud klassika: lähilugemine". Korraldajateks olid Marin Laak ja Johanna Ross, ettekandeid oli ühtekokku 15 esinejalt.

Eesti rahvuseepose "Kalevipoeg" esmailmumise 150. aastapäeva puhul välja antud eepose ingliskeelse uustõlke "Kalevipoeg: the Estonian National Epic / eesti rahvuseepos" pidulik esitlus toimus KUMU Kunstimuuseumis Tallinnas 21. oktoobril, kus sõna said raamatu järelsõnade autorid president Toomas Hendrik Ilves ja Jüri Talvet, Austraalia Eesti Seltside Liidu esimees Arvi Vainomäe, raamatu Illustraatori Gunnar Neeme poeg Ants Neeme Austraaliast, kunstiteadlane Kersti Koll ning raamatu toimetaja ja ürituse peakorraldaja Marin Laak.

EKLA oli osaline ka traditsioonilise, järjekorras juba 55. Kreutzwaldi päevade teadusliku konverentsi organiseerimisel (M. Laak) 21.-22. detsembril, kus seekord oli keskendatud tõlketemaatikale.

Oskar Lutsu 125. sünniaastapäeva tähistamiseks 2012. a. jaanuari algul planeeritud konverentsi korraldustöödega ning teesivihiku koostamisega alustas aasta lõpul Külliki Kuusk.

\section{Ettekanded}

Kultuuriloo allikate ja kirjandusuurimise töörühma liikmed esinesid aasta jooksul kokku 18 ettekandega, neist 11 rahvusvahelistel konverentsidel. Populaarteaduslikke ettekandeid peeti 24 korral.

Eve Annuk pidas ettekande "Poetry and autobiography: reading poetry as a diary" üle-euroopalisel autobiograafiauurijate konverentsil IABA Europe 2011, "Trajectories of (Be)longing: Europe in Life Writing". 28. oktoobril juhatas ta istungit ja pidas ettekande "Researching gender and culture in Estonian context" NEFA konverentsil Tartu Ülikoolis, osaledes samal päeval ka kirjandusmuuseumis Skype'i teel ettekandega "The culinary discourse and the discourse of organic food in Estonia" Poolas toimunud rahvusva- 
helisel konverentsil "Creativity and tradition in Polish and Estonian Cultural Communication".

Rutt Hinrikus osales samuti üle-euroopalisel autobiograafiauurijate konverentsil IABA Europe 2011, “Trajectories of (Be)longing: Europe in Life Writing" ning tema ettekanne kandis pealkirja "A diary of an unknown Estonian woman from Alaska". Eesti TA Underi ja Tuglase Kirjanduskeskuses Artur Adsonile pühendatud seminaril 2. novembril pidas R. Hinrikus A. Adsoni pagulusaegsetele päevaraamatutele tuginedes ettekande "Artur Adson kui kroonik" ning A. H. Tammsaare Muuseumi 7. sügiskonverentsil "Eesti romaan. Sisse- ja väljavaateid" rääkis ta teemal "Mats Traadi üksi rändaja koorem".

Maarja Hollo võttis osa 28. juunil Gotlandil aset leidnud rahvusvahelisest konverentsist "Gotland and the Boat Refugees through Life Stories" ettekandega "Gotland in Three Estonian Life Stories".

Leena Kurvet-Käosaar avas peakorraldajana üle-euroopalise autobiograafiauurijate konverentsi IABA Europe 2011, “ Trajectories of (Be)longing: Europe in Life Writing" ning pidas ettekande "Some Trajectories of (Be)longing". Konverentsil "Transitions, Visions and Beyond" (The 9th Baltic Conference in Europe) 12.-15. juunil Stockholmis rääkis ta teemal "Getting/being there on our own terms: the topos of Europe in Estonia Post-Soviet Life Writing” ning 29. septembril Hawaii Ülikoolis ““The train dragged on with people crying and in despair": Representations of Suffering in Baltic Women's Narratives of Stalinist Repressions".

Külliki Kuusk pidas ettekande Uku Masingu luulest Kultuuriteaduste ja kunstide doktorikooli (KTKDK) ning Kultuuriteooria tippkeskuse (CECT) talvekoolis "Aeg ja ajalisus: kategooriad, mudelid ja narratiivid”, mis toimus 31 . jaanuarist kuni 6 . veebruarini Tartu Ülikoolis. Ettekanne "Lutsu aastaajad" oli teemaks Julius Oro näituse avamisel 21. märtsil Oskar Lutsu majamuuseumis.

Marin Laak osales Eesti Infotehnoloogia Sihtasutuse e-Õppe Arenduskeskuse seminaril "Õppimise evolutsioon antiikajast digiajastuni” 17.-18. novembril Pärnumaa Kutsehariduskeskuses, kus rääkis teemal "Tiigrihüppest kultuuriloolise veebini: mäluasutuste e-varamud ja nende kasutajad". Teemakohase ettekande "Traces 
and Threads: The Kalevipoeg in Modern Estonian Culture" pidas ta rahvusvahelisel sümpoosionil "Traditional and Literary Epics of the World: Textuality, Autorship, Identity. The Kalevipoeg 150". Kreutzwaldi päevadel esines M. Laak ettekandega "“'The Poeg of Kalev": Triinu Kartuse tõlke jälgedel".

Kristi Metste esines Villem Reimani 150. sünniaastapäeva tähistamisel Eesti Kirjandusmuuseumis teemakohase ettekandega "Villem Reiman Faehlmanni uurijana", kus esitles ka väljaannet “F. R. Faehlmann. Teosed III”. Kirjanduspäeval "Betti Alver 105” 24. novembril Betti Alveri Muuseumis Jõgeval rääkis ta $\mathrm{B}$. Alveri novelli "Kõmpa" tähendusest.

Sirje Olesk esines Arno Vihalemma sünniaastapäeva konverentsil ettekandega "Arbujate saatus. Järelarbujad ja teised", Gröningeni Ülikoolis 7.-9. juulil toimunud V Rahvusvahelisel Soome-Ugri sümpoosionil ettekandega "Oral history, cliches and facts in a literary text: The novel "Purge" by Sofi Oksanen" ning Soome Kirjanduse Seltsi Kirjandusarhiivi 40. aastapäeva seminaril Helsingis 18. oktoobril teemal "Kirjallisuus, kirjallisuushistoria ja arkisto".

Vello Paatsi esines Kreutzwaldi päevadel ettekandega "Terre, armas eesti rahvas".

Johanna Ross kõneles Nüpli 1. kirjanduse suvekoolis teemal "Toidu valmistamine nõukogude eesti olmekirjanduses", samuti oli tal ettekanne 16. septembril Tallinna Kirjanike Majas toimunud konverentsil "Võlus ja vaimus, valguses ja varjus", mis oli pühendatud Mari Saadi loomingule ning ettekande pealkirjaks oli "Mari Saat kui "naiskirjanduse" proovikivi".

\section{Väljaanded ja publikatsioonid}

Arhiivikogude baasil ilmus 2011. a. neli raamatut. Valmis Eesti Kirjandusmuuseumi ja Eesti TA Underi ja Tuglase Kirjanduskeskuse tekstikriitiline ühisväljaanne "F. R. Faehlmann. Teosed III", mille koostajaks ja toimetajaks oli Kristi Metste koostöös Jaan Unduski ja Marju Lepajõega. Raamatus avaldati ka K. Metste artikkel “Dok- 
tor Faehlmanni kolm raamatut”. Koostöös ühendusega Eesti Elulood koostas Rutt Hinrikus raamatu "Sõjas kasvanud poisid: Eesti meeste mälestused sõjast ja Saksa okupatsioonist”.

Sirje Olesk ja Tiina Saluvere koostasid ajakirja Methis. Studia humaniora Estonica nr 7, nõukogude aja erinumbri, mille aluseks oli 2009. a. T. Saluvere poolt korraldatud konverents "Kaarel Ird ja tema aeg". Tulemuseks oli interdistsiplinaarne nõukogude aja eri valdkondi käsitlev kogumik, mida esitleti kevadisel eluloopäeval. Lisaks S. Oleski ja T. Saluvere põhjalikule saatesõnale olid selles artiklid Eve Annukilt ("Honoraripoliitikast Eestis stalinismi perioodil”), Sirje Oleskilt (“Taistolased - kas sinisilmsed idealistid või ortodokssed stalinistid?”) ning Tiina Saluverelt, kes kirjutas huvitava kaastöö rubriigis "Arhiivileid" ("Kaebekirjade kiituseks ehk kommentaariks ühele arhivaalile”). M. Laak koostöös J. Tombergiga valmistas ette Methise $\mathrm{nr}$ 8, interdistsiplinaarse vabanumbri, mille keeletoimetamisega olid seotud M. Hollo ja T. Saluvere.

Sarjas "Studia Fennica” ilmus Leena Kurvet-Käosaare ja Lea Rojola koostatud ja toimetatud kogumik "Aino Kallas: Negotiations with Modernity”. Artiklid olid selles nii L. Kurvet-Käosaarelt ("The Vitality of Primeval Peasant Blood. The Role of Heredity in the Work of Aino Kallas") kui Sirje Oleskilt ("Aino Kallas on the Boundaries of Finland, Estonia and the World").

2011. a. oktoobris ilmus aastatepikkuse töö tulemusena trükist eesti rahvuseepose "Kalevipoeg" ingliskeelne uustõlge, mille käsikiri jõudis EKLAsse Austraaliast. Selle tõlkijaks oli Triinu Kartus ja kujunduse aluseks Gunnar Neeme pildid. Sarjas "Humaniora: germanistika 5" ilmunud "Nationalepen zwischen Fakten und Fiktionene" avaldati Marin Laagi ja Piret Viirese ühisartikkel "The Estonia Epic Kalevipoeg in Cultural and Literary Reception”.

Raamatus "Soldiers of Memory. World War II and its Aftermath in Estonian Post-Soviet Life Stories" (toim. E. Kõresaar; New York, Amsterdam: Rodopi) ilmus Rutt Hinrikuse artikkel "How to remember? The Social Framework of Reinhold Mirk's Reminiscences of War". Sirje Oleskilt avaldati kogumikus “Tartu Historical Studies" (toim O. Mertelsmann; Frankfurt am Main. Berlin. 
Bern. Bruxelles. New York. Oxford. Wien) artikkel “Writers' Collaboration with the Soviet Authorities and the Dominant Literary Journal in the Estonian SSR in the 1940s and1950s" ning koos Piret Viiresega kogumikus "Uurimusi 1940. aastate eesti kirjanduses" artikkel "Pöördelised neljakümnendad". Ajakirja Interlitteraria 16. väljaandes avaldati Leena Kurvet-Käosaare artikkel "Throwing Mud in the Face or Gentle Journeys into Frames of Time? Some Notes on Post-Soviet Life-Writing in Estonia".

Traditsiooniliselt jätkus EKLA allikmaterjalide põhjal regulaarne kaastööde avaldamine ajalookultuuriajakirjas Tuna. Külliki Kuusk avaldas katkendeid Uku Masingu ja Bernard Kangro kirjavahetusest (“Tänan vahtrategi meenutamise eest..."), Sirje Olesk arhiivimaterjale eesti ja soome suhetest ("Pagulased ja kodumaa. Kirjad Soomest”), Vello Paatsi Gustav Maltsast ja tema käsikirju ("Maakuulajate reis Krimmi ja Gustav Malts", "Ajalugu Maltsveti usust ja Krimmi rändamisest”), Tiina Saluvere A. Vihalemma kirju K. Irdile ("Kaks ärkliarmeelast - Vana Viha ja Vana Hirmus"). Ajakirjas Looming ilmus aasta jooksul kolm artiklit Sirje Oleskilt: "Rein Riitsalu kiri Soomest", "Nõukogude Eesti raamatud väliseestlaste lugemislaual" ja "Arhiividesse kadunud... et uurimustes sündida”. Ajakirjas Keel ja Kirjandus avaldasid oma artikleid Vello Paatsi ("Haruldane raamatuleid Eesti Kirjandusmuuseumi Arhiivraamatukogust" (kaasautor Ave Pill) ja "Kus ja millal sündis Jaan Sandra") ning Johanna Ross ("Naised, nišid ja nullid”).

Rutt Hinrikus ja Tiina Kirss koostasid ENÜSi 100. aastapäeva puhul mahuka väljaande "Eesti Naisüliõpilaste Selts: vaateid ajalukku”, milles ilmus ka R. Hinrikuse artikkel "Eesti naine, haridus ja "naisterahva küsimus" 20. sajandi alguses".

Mitmetes perioodilistes kultuuriväljaannetes nii Eestis kui välismaal ilmus teematäitjailt ka populaarteaduslikke artikleid, ülevaateid ja arvustusi. Samuti kirjutati väljaannete järelsõnu, koostati kirjeid teatmeteostesse, retsenseeriti teadusartikleid (E. Annuk, R. Hinrikus, K. Kuusk, M. Laak, K. Metste, S. Olesk, V. Paatsi, J. Ross, T. Saluvere).

Aasta jooksul töötati mitmete käsikirjadega, mis jäid oma ilmumisaega ootama: "Voicing Trauma in the Deportation Narratives 
of Baltic Women" (L. Kurvet-Käosaar); "What Oly Fiction Can Do” (L. Kurvet-Käosaar); “Uku Masingu 1930. aastate luule seosed rahvalauluga: kordus ja parallelism” (K. Kuusk); "Heritage, User and the Environment: Rewriting the Narrative of the Literary Past in the Digital Space" (M. Laak); "Literary Canon in the Digital Era: Re-thinking the Estonian National Epic Kalevipoeg” (M. Laak ja P. Viires); "Marie von Bruiningki tundeline revolutsioon. Märkmeid ühest Faehlmanni patsiendist" (K. Metste); J. H. Rosenplänter "Maa-keele päevaraamat" 1833 (koost. ja toim. K. Metste ja V. Paatsi); "Aus der statistischen und geographischen Wissenschaften in die Geschichte und Politik Russlands. Carl Schirren und sein heranwachsen" (V. Paatsi ja E. Tammiksaar).

\section{Õppetöö ja juhendamine}

Töörühma liikmetest jätkasid Tartu Ülikoolis doktorantuuriõpinguid Maarja Hollo, Külliki Kuusk, Marju Mikkel ja Johanna Ross eesti kirjanduse ja kultuuriteaduste alal ning Tiina Saluvere teatriteaduse alal. Viimane luges ka TÜ-s eesti teatri ajaloo kursust.

Vello Paatsi luges kevadsemestril Tartu Ülikooli kunstide osakonnas loengukursust "Kunstiõpetuse ajaloost eesti koolis" ning oli kaasjuhendajaks K. Paatsi ajaloo osakonnas kaitstud magistritööle "Kalender eestlase ajaloo-alase maailmapildi kujundajana 18. sajandi algusest 1905. aastani".

Eve Annuk pidas TÜ kraadiõppe üliõpilastele loengukursuse tekstoloogiast ning osales juhendajana TTKK ja TÜ doktorikooli korraldamises (ingliskeelne loeng ja seminar arhiividest). Samuti on ta A. Mandeli magistritöö ja T. Saluvere doktoritöö juhendaja.

Marin Laak on M. Mikkeli, K. Ojasaare ja P.-R. Larmi doktoritööde juhendaja ning Sirje Olesk J. Kronbergi ja J. Rossi doktoritöö juhendaja.

Oponeeriti TÜ eesti kirjanduse õppetoolis kaitstud bakalaureusetöid: K. Hüvato "Mati Undi romaanid "Hüvasti, kollane kass" ja 
“Tere, kollane kass"” (K. Kuusk) ning H. Hundi "Fr. R. Kreutzwaldi "Kalevipoja” retseptsioon nüüdisajal” (M. Laak).

\section{Koostöö}

Koostöös Tartu Ülikooli, Eesti Kunstiakadeemia, Underi ja Tuglase Kirjanduskeskuse ning Eesti Kirjandusmuuseumi rahvaluule arhiivi sihtfinantseeritava teema töögrupiga osalesid mõlemad EKLA töörühmad Eesti Teaduse Tippkeskuse projektikonkursil, mille raames töötati välja ja esitati uus tippkeskuse projekt CELAR (“Centre of Literature and Art Research"), projekti juht oli M. Laak.

Rahvusvahelise teaduskolleegiumiga eelretsenseeritava teadusajakirja Methis. Studia humaniora Estonica (peatoimetaja M. Laak, vt www.methis.ee) väljaandmist jätkati koos Tartu Ülikooli kultuuriteaduste ja kunstide instituudiga.

Eve Annuk osales Põhjamaade biograafiauurijate võrgustikus ning Eesti ja Poola TA vahelises koostööprojektis "Creativity and Tradition in Polish and Estonian Cultural Communication".

Koostöö Tartu Ülikooliga toimus ka nii loengukursuste kui üliõpilaste arhiivipraktika kaudu.

\section{Muud tegevused}

2011. aasta teisel poolel alustati Eesti elulugude ja mälestuste andmebaasi väljatöötamist (http://galerii.kirmus.ee/elma/) ja andmesisestust, millega tegelesid L. Kurvet-Käosaar, T. Saluvere ja J. Ilja. Kirjandusmuuseumi failirepositooriumi "Kivike" tarkvararühma töös osalesid M. Laak, M. Mikkel ja T. Saluvere.

Leena Kurvet-Käosaar viibis aasta lõpukuudel J. William Fulbrighti stipendiaadina uurimistööl Hawaii ülikooli biograafiauuringute keskuses (Center for Biographical Research, University of Hawaii at Manoa, USA). 
Kvalifikatsiooni tõstmise eesmärgil osaleti aasta jooksul konverentsidel ja seminaridel, töötati arhiivides ning raamatukogudes. Eve Annuk osales Euroopa teadusfondi konverentsil "First person writing, four ways reading” Londoni Ülikoolis; Vello Paatsi tutvus arhiividokumentidega ja kogus materjale Tallinnas ennistuskojas Kanut, osales Kaika suveülikoolis ning töötas Riias Läti Riiklikus Ajalooarhiivis, kus kogus materjale $\mathrm{H}$. Rosenplänteri päeviku avaldamiseks.

27.-29. oktoobril viibis Sirje Olesk Helsingi raamatumessil, mille teemamaa oli seekord Eesti. Ta osales seminaril "Viron henki Suomessa", oli seminari "Muisti ja omaelämäkerrallisuus" moderaator ning esitles ka E. Mihkelsoni romaani "Ruttohauta" ("Katkuhaud").

Töörühma liikmed kuulusid ja enamasti kuuluvad praeguseni ka mitmetesse nõukogudesse, kolleegiumitesse, seltsidesse jm ühendustesse. Leena Kurvet-Käosaar on Euroopa Rahvusvahelise Autobiograafiauuringute Assotsiatsiooni (IABA Europe) juhatuse liige ning Balti Põhja-Ameerika uuringute Keskuse (Baltic Center for North-American Studies), Rahvusvahelise Võrdleva Kirjandusteaduse Assotsiatsiooni (EACL) ning Eesti Võrdleva Kirjandusteaduse Assotsiatiooni (EVKA) liige. Samuti on ta ajakirja Ariadne Lõng toimetuse kolleegiumi liige, Eesti Teaduskompetentsinõukogu ekspert, Islandi Teaduste Akadeemia ekspert ning ajakirjade Keel ja Kirjandus ning Trames retsensent.

Marin Laak on Balti uuringute Assotsiatsiooni (Accociation for the Advancement of Baltic Studies) ja Eesti Võrdleva Kirjandusteaduse Assotsiatsiooni (EVKA) liige. Samuti kuulus ta 2011. a. Eesti Kultuurkapitali kirjanduse sihtkapitali nõukokku. Eve Annuk on ajakirja Ariadne Lõng peatoimetaja ning TÜ kultuuriteaduste ja kunstide instituudi sarja "Studia literaria Estonica" kolleegiumi, Eesti Kultuurkapitali kirjanduse sihtkapitali nõukogu ja Tartu Kultuurkapitali G. Suitsu luulestipendiumi auhinnakomisjoni liige. Rutt Hinrikus on Soome Kirjanduse Seltsi kirjavahetajaliige, Tartu Kultuurkapitali nõukogu, ühenduse "Eesti elulood” ja Emakeele Seltsi liige. Külliki Kuusk ja Kristi Metste osalesid liikmetena Uku Masingu Kolleegiumis ning Sirje Olesk jätkas tööd TÜ kul- 
tuuriteaduste ja kunstide instituudi nõukogu liikmena. Piret Noorhani on MTÜ Baltic Heritage Network president ja portaali www. balther.net peatoimetaja, rahvuskaaslaste programmi arhiiviprojektide hindamiskomisjoni liige, Balti Audiovisuaalsete Arhiivide Kolleegiumi liige ja revisjonikomisjoni esimees ning Villem Reimani Kolleegiumi liige.

Eesti Kirjanduse Seltsi kuuluvad Marin Laak (juhatuses), Rutt Hinrikus, Maarja Hollo, Külliki Kuusk, Piret Noorhani ja Sirje Olesk; Karl Ristikivi Seltsi kuuluvad Rutt Hinrikus (juhatuses), Marin Laak, Piret Noorhani ja Sirje Olesk.

On osaletud ka muuseumivälistes ettevõtmistes: Johanna Ross oli Eesti Kultuurkapitali 2010. a. kirjanduspreemiate žüriis ning osales festivali Ladyfest kirjandussektsiooni organiseerimisel; Marin Laak osales rahvusraamatukogu veebiarhiveerimise töörühmas.

\section{Kultuuri- ja kirjandusteooria töörühm}

\section{Teadusprojektid}

2011. aastal jätkus sihtfinantseeritava teadusteema "Mimeesi retoorilised alusmustrid ja eesti tekstikultuur" (SF0030054s08, 2008-2013, teemajuht Virve Sarapik) täitmine. Uurimistöö oli fokuseeritud kahe keskme ümber: 1) fiktsionaalsuse analüüs, lähtudes selle toimimise ja representatsiooni (mimees) eri aspektidest; 2) nüüdiskultuuri analüüs, sh kuidas digitaalne ajastu on muutnud arusaamu tekstist ja kultuurist üldiselt. Teema täitmist toetasid riikliku programmi "Eesti keel ja kultuurimälu" projekt "Eelretsenseeritava humanitaarteadusliku monograafiasarja "Heuremata" väljaandmise jätkamine” (projektijuht Piret Viires, EKKM09114, 2009-2013); Eesti Teadusfondi grant "Osaluskultuur küberruumis: kirjandus ja tema piirid” (vastutav täitja Piret Viires, täitjad Raivo Kelomees, Virve Sarapik, Jaak Tomberg, nr 7679, 2008-2011) ja MOBILITAS Postdoctoral Research Grant "On the Contemporary 
Convergence of Realism and Science Fiction" (vastutav täitja Jaak Tomberg, nr MJD129, 2010-2012).

\section{Konverentside ja teadusürituste korraldamine}

13.-15. mail toimus USAs Massachusettsis rahvusvaheline konverents "Media in Transition 7. Unstable Platforms: the Promise and Peril of Transition", mille ühe ettekandepaneeli "Narratives in Transition: Digital Life Writing, Digital Lives" korraldajaks oli Piret Viires. Töörühma korraldusel toimus aasta jooksul kaks teaduskonverentsi. Tartu Kirjanduse Majas leidis 13. mail aset filosoofilist mõeldavust käsitlev konverentsipäev "Eshatoloogia ja apokalüpsis", mis oli jätkuks eelnenud aastate konverentsidele "Unustuse arhiiv" (2008), "Unustuse arheoloogia" (2009) ja "Tuleviku arheoloogiad" (2010). Seekord räägiti representatsiooni piiridest, korraldajateks olid Neeme Lopp ja Jaak Tomberg. Tallinna Kirjanike Majas korraldati 16. septembril Piret Viirese koostöös Kirjanike Liiduga konverents Mari Saadi loomingust pealkirjaga "Võlus ja vaimus, valguses ja varjus". Tööaastasse jäi 2012. a. kevadel toimuva Rahvusvahelise Filosoofia ja Kirjanduse Assotsiatsiooni (IAPL) aastakonverentsi "Archeologies of the Future: Tracing Memories, Imagining Spaces" ettevalmistamine ning samuti töörühma seminarid, mida oli kokku seitse.

\section{Ettekanded}

Rahvusvahelistel konverentsidel ja seminaridel esinesid töörühma liikmed ettekannetega kokku 13 korral. USAs New Orleansis 10.13. märtsil toimunud aastakonverentsil "Society for Cinema and Media Studies" rääkisid filmi ja kino teemal Mari Laaniste ja Eva Näripea; 14. märtsil pidas Jaak Tomberg ettekande "On the General Representability of the Other" Londoni Ülikooli kolledžis; igakevadisel, seekord 14.-17. aprillil Columbia Ülikoolis USAs toimunud 
aastakonverentsil "16th Annual World Convention of the Association for the Study of Nationalities. Charting the Nation between State and Society" pidas ettekande Epp Annus. Teemakohaste ettekannetega Massachusettsi Tehnoloogiainstituudis USAs osalesid Virve Sarapik ja Piret Viires, kus 13.-15. mail leidis aset konverents "Media in Transition 7. Unstable Platforms: the Promise and Peril of Transition". 35. Rahvusvahelisel Filosoofia ja Kirjanduse Assotsiatsiooni (IAPL) konverentsil 23.-29. mail Taiwanis, Rahvusvahelises Cheng Kung Ülikoolis esines ettekandega Epp Annus, kes ühtlasi pidas seal ka tervituskõne kui järgmise, 36. aastakonverentsi peakoordinaator. Samuti osales E. Annus ettekandega rahvusvahelisel filosoofiaseminaril (International Philosophical Seminar: JeanLuc Nancy) Itaalias Kastelruthis 28. juunil - 10. juulil.

2011. a. sügisel peeti ettekandeid neljal rahvusvahelisel konverentsil: Eva Näripea 6.-7. oktoobril Kopenhaagenis Taani Filmiinstituudis konverentsil "New Polish and Other Eastern European Cinema”; Epp Annus 28.-29. oktoobril Tallinnas Underi ja Tuglase Kirjanduskeskuses konverentsil "From Past to Present: Transformations of Memory in Contemporary Culture"; Virve Sarapik 9.-12. novembril Norras Bergeni Ülikoolis konverentsil "Nomadikon: IMAGE=GESTURE"; Luule Epner 22.-23. novembril Riias konverentsil "Text in Contemporary Theatre".

Kodumaistel konverentsidel peeti töörühma poolt 10 ettekannet: konverentsil "Eshatoloogia ja apokalüpsis" 13. mail Tartus Kirjanduse Majas esinesid Neeme Lopp ja Jaak Tomberg; konverentsil "Urban Semiotics" 3.-5. juunil Tallinna Ülikoolis esines Epp Annus; Mari Saadi loomingut käsitleval konverentsil "Võlus ja vaimus, valguses ja varjus" 16. septembril Tallinna Kirjanike Majas pidasid ettekande Epp Annus ja Luule Epner; Eesti Teatriuurijate Ühenduse aastakonverentsil "Eesti teater sajandivahetusel: suur pauk?” 2.-3. detsembril Von Krahli Teatris Tallinnas rääkis 1990. aastate teatrist Luule Epner. Traditsiooniliselt igal aastal toimuvas Nüpli suvekoolis rääkis Epp Annus teemal "Milleks lugeda Mats Traati?” ning töörühma seminaridel kõnelesid kultuuri- ja kirjandusteooria teemadel Epp Annus, Mari Laaniste, Neeme Lopp ja Eva Näripea. 


\section{Väljaanded ja publikatsioonid}

Humanitaarteaduslike monograafiate sarjas ilmus Jaak Tombergi monograafia "Kirjanduse lepitav otstarve", mis on kirjandusteoreetiline uurimus väljamõeldise üldisest filosoofilisest funktsioonist. Valmis ka Piret Viirese monograafia "Postmodernism in Estonian Literary Culture” käsikiri (Frankfurt am Main: Peter Lang Verlag). Sarjas "Etüüde nüüdiskultuurist" avaldati kolmanda raamatuna artiklikogumik "Luhtatulek. Ekslemisi Mehis Heinsaare tihnikutes" (koostaja Sven Vabar, toimetaja Mari Laaniste). Teatri- ja filmiteooria vallast ilmusid Luule Epneri koostatud kogumik "Valitud artikleid teatriuurimisest" ning Eva Näripea koostatud ajakirja Kunstiteaduslikke Uurimusi erinumber "Eesti filmi sajand". Piret Viires oli üks artiklikogumiku "Uurimusi 1940. aastate eesti kirjandusest" koostajatest.

Ilmus Kunstiteaduslikke Uurimusi / Studies on Art and Architecture 2011 / 1-2, nr 20 (peatoimetaja Virve Sarapik). Luule Epneri toimetatuna anti välja raamatud "Vahing. Mälestusi Vaino Vahingust" ja Jaan Toominga "Religioossed motiivid minu loomingus", Mari Laaniste toimetas kogumiku "Call It A Day. Contemporary Comics from Finland, Estonia, Hungary and Latvia”. Eva Näripea, Mari Laaniste ja Andreas Trosseki tõlkes ilmus Robert Stami "Filmiteooria. Sissejuhatus".

Teadusartikleid ja koguteoste peatükke kirjutasid töörühma teadurid kokku 26, neist viiel korral oldi kaasautoriks. Tööd ilmusid või on ilmumas sellistes perioodilistes väljaannetes nagu Interlitteraria, Kunstiteaduslikke Uurimusi, Methis. Studia humaniora Estonica, Humaniora Germanistica, Looming, Teater. Muusika. Kino, Vikerkaar ning sarja kogumikes "Etüüde nüüdiskultuurist". Arvukalt publitseeriti ka lühiartikleid, arvustusi, saatesõnu, ülevaateid ja kommentaare nii eesti- kui võõrkeelsetes väljaannetes. 


\section{Õppetöö ja juhendamine}

2011. aastasse jäi Eva Näripea doktoriväitekirja "Estonian Cinescapes: Spaces, Places and Sites in Soviet Estonian Cinema (and Beyond)" ("Eesti filmimaastikud. Ruumid, kohad ja paigad Nõukogude Eesti filmis (ning edaspidi)") kaitsmine Eesti Kunstiakadeemias kunstiteaduse erialal (juhendajad V. Sarapik ja M. Kalm). Töö hinnati kõrgeima hindega ja see käsitles Nõukogude Eesti filmikunsti ruumirepresentatsioonide kaudu, kaardistades perioodi ekraaniteostes leiduvaid linna-, küla- ja meelemaastikke. Väitekiri ilmus sarjas "Dissertationes Academiae Artium Estoniae".

Tartu Ülikooli kirjanduse ja rahvaluule doktoriõppes jätkas Neeme Lopp, väitekirja teemaks "Kirjandus kui infrastruktuur" (juhendaja A. Merilai).

Juhendati neli magistriväitekirja, neist kaks Tartu Ülikooli filosoofiateaduskonna kultuuriteaduste ja kunstide instituudis (juhendaja L. Epner) ning üks TÜs maailmakirjanduse erialal (kaasjuhendaja J. Tomberg) ja üks magistritöö Eesti Kunstiakadeemias kunstiteaduse erialal (juhendaja V. Sarapik). Juhendamisel on aga veel kokku 17 doktoritööd (L. Epner, K. Lehari, V. Sarapik, P. Viires) nii Eesti Kunstiakadeemias kui Tallinna ja Tartu Ülikoolis.

Loengukursusi teatriteadusest Tartu ja Tallinna Ülikoolis ning Eesti Muusika- ja Teatriakadeemia Lavakunstikoolis pidas Luule Epner; kunstiteadusest, semiootikast ja esteetika ajaloost Eesti Kunstiakadeemia kunstiteaduse instituudis Virve Sarapik; eesti kirjandusest Tallinna Ülikoolis Piret Viires ning ühe loengukursuse kevadsemestril teemal "Kriitika ja analüüs 3" Eesti Kunstiakadeemia fotoeriala tudengitele viis läbi Jaak Tomberg. L. Epner oponeeris ka EMTA Lavakunstikoolis ühte doktori- ja kahte magistritööd ning ühte magistritööd maailmakirjanduse erialal Tartu Ülikoolis. 


\section{Muud tegevused}

Kultuuri- ja kirjandusteooria töörühma teadurid kuuluvad järgmiste väljaannete toimetuskolleegiumitesse: Methis. Sudia humaniora Estonica (L. Epner, V. Sarapik, P. Viires); humanitaarmonograafiate sari "Heuremata" (L. Epner, V. Sarapik); "Studia Romanica Tartuensia" (L. Epner); "Eesti teatri biograafiline leksikon" (L. Epner); "Acta Universitatis Tallinnensis" sari "Artes" (V. Sarapik), Estonian Literary Magazine (P. Viires); Kunstiteaduslikke Uurimusi (peatoimetaja V. Sarapik). Luule Epner on riikliku programmi "Eesti kirjandusklassika" komisjoni liige ning EMTA magistrikraadide kaitsmisnõukogu liige, Virve Sarapik on Eesti Kunstiakadeemia kunstiteaduse doktorinõukogu liige ja teadusnõukogu esinaine ning Eesti Kirjandusmuuseumi teadusnõukogu liige, Piret Viires kuulub Tallinna Ülikooli Eesti Keele ja Kultuuri Instituudi nõukogusse, on AILC/ICLA Research Committee on Comparative Literature in the Digital Age liige, Eesti Kirjanduse Teabekeskuse juhatuse liige ning Eesti Kirjanike Liidu aseesimees.

Aasta jooksul viibiti ka mitmetel välislähetustel, kus osaleti erialastel konverentsidel ja sümpoosionitel ning töötati arhiivides ja raamatukogudes.

\section{Arhiivitöö}

Arhiivitöö finantseerimine toimus Haridus- ja Teadusministeeriumi poolt teaduskollektsioonide rahastamise baasil ning rahvuskaaslaste programmi projekti "Väliseesti kultuuriajaloo allikmaterjalide kogumine, korraldamine, digiteerimine ja andmebaasistamine Eesti Kultuuriloolises Arhiivis" raames. Arhiivi tööjõukulusid toetas ka sihtfinantseeritav teadusteema "Kultuuriloo allikad ja kirjanduse kontekstuaalsus" ning sellega seotud väikesemahulise teaduse infrastruktuuri kaasajastamise projekt (SF0030065s08AP11), mille abil täiendati EKLA fotolabori sisus- 
tust ja suurendati veebiserveri mahtu EKLA andmebaaside teenindamiseks.

\section{Kogumine}

2011. aastal jätkus Eesti Kultuuriloolises Arhiivis tavapärane kogumistöö. Ühelt poolt põhines see vabatahtlikel kultuuriajalooliste materjalide annetustel, teisalt oli see arhiivipoolne süsteemne ajalooainese koondamine ning kultuurisündmuste ja -isikute jäädvustamine. Selle tulemuseks oli 162 registreeritud laekumist, kokku 13284 säilitusühikut nii käsikirjade, foto-, kunsti-, heli- kui filmikogusse.

Kõige mahukamad hoiustatud käsikirjalised personaalarhiivid olid Andres Vanapa, Leo Metsari, Helju Valsi, Fanny de Siversi ja Ilse Lehiste kogud, neist viimased saadeti EKLAsse vastavalt Prantsusmaalt ja USAst. Arvestatavad olid lisalaekumised Bernard Kangro, Valmar Adamsi, Elmar Kaldi ja "Sõnavara" kirjastuse ning õpilaste ajalooalaste võistlustööde materjalidele. Registreeriti MÜA (Metsaülikool Austraalias), Eesti Naisklubi Stockholmis, Uppsala Eesti skautide ja gaidide materjalide, Kirjanike Liidu, kultuuriministeeriumi võistlustööde, Endla Hermanni, Priidu Puusepa, Aldo Kalsi, Olaf Tammarki jt arhiiviainese vastuvõtt, samuti aastakümneid hõlmavad Artur Adsoni ja Marie Underi kirjad Õie Fleigile Šveitsi ning Vaino Vahingu jt kirjad Ilvi Jõe-Cannonile USAsse ning mitmeid kultuuriajalooliselt olulisi üksiklaekumisi. Rutt Hinrikus suunas ja koordineeris elulugude kogumist. Oldi osalised Eesti Päevalehe ja ajakirja Akadeemia "Eesti Mälu” sarja initsiatiivil toimunud eluloovõistluse toimumisel, mille tulemusena laekus EKLA elulugude fondi 45 elulugu. Lisaks arhiveeriti 16 säilikut mälestusi. Kokku registreeriti 5609 säilikut käsikirjalist originaalmaterjali.

Fotokogu sai lisa Salme Ekbaumi ja Endla Hermanni personaalarhiivi, Kalju Suure autorikogu kirjanike fotode, Eesti Naisklubi fotoalbumite ning teiste arvukate kultuuriajalooliste 
isikute ja sündmuste pildijäädvustustega. Oluliselt suurendasid fotokogu laekumiste arvu digitaalsed pildistused kirjandus- ja kultuurisündmustest. Projekti "Kirjanik ja tema keskkond" raames jätkus kirjanike, luuletajate, tõlkijate ja kirjandusteadlaste fotografeerimine nende endi valitud keskkonnas. Seekord pildistati Harju-, Rapla-, Lääne- ja Hiiumaal ning Tallinnas ja Tartus kokku 25 literaati, mille tulemusena lisandus arhiivi 764 pildifaili. Valikuliselt, kuid valdavas enamuses on valmistatud vastavalt võimalustele digitaalsetest pildistustest ka tagatiskoopiad. Kokku laekus 2011. a. fotokogusse 6656 säilikut pildimaterjali.

Kunstikogusse lisandus ligi 800 eksliibrist Tartu Eksliibriseklubilt ja mitmeid graafilisi töid (844 säilikut). Audiovisuaalsesse kogusse laekus arvukalt kassette lindistustega kirjandus- ja kultuurilooliste isikute intervjuudest, mälestustest, esinemistest ning Eesti Muinsuskaitse Seltsi koosolekutest, vestlusringidest jm (161 säilikut), lisaks kultuuriloolisi filme (14 säilikut).

Annetajatest tuleb kindlasti tänada ennekõike neid, kes järjepidevalt on arhiivikogude täiendamise eest hoolt kandnud ning kes ka 2011. a. oma panuse andsid: Virve Adamson, Agu Kaljo, Aldo Kals, Jaan Malin, Enn Nõu, Mart Orav, Ille Palm, Viivi Rohtla, Heino Ross, Heino Räim, Kalju Suur jt. Väliseesti arhiivikogude kohalejõudmise eest väärivad tänu Inno ja Tiiu Salasoo, Epp Annus, Urmas Bereczki, Irja Cilluffo, Leelja Seensalu ja Piret Viires.

\section{Korraldamine}

EKLA arhivaarid ja assistendid korraldasid aasta jooksul mitmeid käsikirjalisi arhiive, neist lõplikult Johannes Semperi, Ine Viidingu, Oskar Kuninga, ja Astrid Reinla / Boris Kaburi kogud (korraldaja Leili Punga); Märt Raua ja Voldemar Ermi kogud (Johanna Ross) ning Asta Willmanni kogu (Maarja Hollo). J. Ross korrastas provisoorselt ka Arvo Mägi kirjavahetust ning L. Punga jätkas Leo Metsari personaalkogu korraldamist. Töölähetusel Sydneys korraldas M. Laak provisoorselt Metsaülikool Austraalias (MÜA) 
arhiivi. Lõpusirgele on jõudnud ka väga mahukas, iga-aastaste lisalaekumistega Eesti Komitee arhiivi korrastamine (Mari Õunapuu). Arvuliselt korraldati käsikirju kokku 4455 säilikut.

Fotoarhiividest lõpetati töö suure ajalehe "Sirp" pildikoguga (Elo Maandi) ning korraldati Oskar Looritsa ja Arvo Mägi personaalarhiivid ja lisandunud materjal Ivar Ivaski, Ella Ilbaku ja Kalju Suure ning ajalehe Teataja kogudesse - kokku 4070 fotot ja negatiivi (Irma Pilt). Paralleelselt laekumistega arhiveeriti ja korrastati helija filmimaterjali (Maarja Savan). EKLA oli ja on jätkuvalt koostöös Tartu Ülikooli eesti kirjanduse õppetooliga ning samuti Viljandi Kultuuriakadeemia info- ja dokumendihalduse osakonnaga, pakkudes võimalust arhiivipraktikaks. 2011. aastal sooritasid kultuuriloolises arhiivis V. Asmeri juhendamisel õppepraktika kolm üliõpilast, kes korrastasid provisoorselt Eesti Ajalooõpetajate Seltsi poolt arhiivile üle antud õpilaste ajalooalaseid võistlustöid (Maris Saar Tartu Ülikoolist) ning Leo Metsari arhiivi (Maire Pariots Viljandi Kultuuriakadeemiast ja Kairi Terav Tartu Ülikoolist).

\section{Kogude kasutamine}

Üks osa arhivaaride ja assistentide igapäevatöös on materjalide korraldamise kõrval uurijate nõustamine, kohalkasutuseks materjalide fondist väljatoomine, tellimuste vormistamine, koopiate valmistamine ja teabenõuetele vastamine nii telefoni kui kirjade teel. 2011. a. külastas Eesti Kultuuriloolist Arhiivi 233 registreeritud uurijat, keda teenindati kokku 532 korda ja toodi fondidest 5072 säilikut. Valmistati 2345 lehte paberkoopiaid ning 970 digikoopiat, vastati ligikaudu 250 arhiivipäringule. Erialaliselt oli uurijate ring väga avar - literaadid, ajaloolased, ajakirjanikud, etnoloogid, kirjastajad, folkloristid, kunsti-, muusika-, kiriku- ja teatriajaloolased, genealoogid, keeleteadlased, muuseumi- ja raamatukogutöötajad, õppejõud ja üliõpilased, koduloolased jpt. Külastajaid oli ka väljastpoolt Eestit - Soomest, Saksamaalt, Inglismaalt, Hispaaniast, Kanadast, USAst ning Austraaliast, peamiselt sealsete ülikoolide 
õppejõud ja üliõpilased. Uurimisteemad hõlmasid väga erinevate eluvaldkondade ajalugu, nagu näiteks kirjastustegevus, fotograafia, arhitektuur, pedagoogika, kirikulugu, merendus, metsandus, kohapärimus, rahvamuusika, folkloor jm. Aktiivne ja järjepidev on EKLA teaduskollektsioonide kasutamine ka asutusesiseselt, sõltuvalt teadurite uurimisteemadest ja töös olevatest projektidest.

\section{Arhiivikogude tutvustamine avalikkusele}

Arhiivikogude tutvustamise ühe väljundina on saanud traditsiooniks koostada kogudepõhiseid tähtpäevanäitusi, millega kaasnevad konverentsid või ettekandepäevad. 2011. a. oli neid kokku kolm. Märtsis tähistati eesti rahvusliku liikumise ühe olulisema tegelase Villem Reimani 150. sünniaastapäeva, mille raames koos näituse avamise ja päevakohaste ettekannetega (V. Asmer Villem Reimani arhiivikogust ja K. Metste Villem Reimanist Faehlmanni uurijana) esitleti ka EKLA materjalidel põhinevat Friedrich Robert Faehlmanni “Teoste” III köidet. Näituse koostamisel andsid oma panuse Vilve Asmer, Kristi Metste ja Leili Punga, ettekandepäeva osas toimus koostöö Villem Reimani Kolleegiumiga. Arno Vihalemma 100. sünniaastapäeva konverentsi täiendas samuti põhjalik ekspositsioon (M. Laak ja V. Asmer). Väljapaneku koostamisel olid väga suureks abiks Arno Vihalemma poegadelt saadud graafilised tööd, fotod ja muu illustreeriv materjal, samuti deponeeriti selleks puhuks Vihalemma töid ka Tartu Kunstimuuseumist. Aasta lõpp möödus rahvuseepose "Kalevipoeg" ilmumise 150. juubeli valguses ning selleks puhuks panid M. Laak ja K. Metste kokku näituse pealkirjaga "Kalevipoeg 150: kingitus Eestile".

Põhjust arhiivimaterjalide tutvustamiseks andsid ka Pärnu kunstniku Vello Paluoja portreemaalide näitused "Inimesi Eesti kultuuriloos I-III", mis toimusid kahel korral Eesti Kirjandusmuuseumis. Vitriinidesse lisati pastelltehnikas töödel kujutatud kultuuriajaloost tuntud tegelaste autograafe, mida valisid V. Asmer ja L. Punga. 
Kuna 2012. a. jaanuari algul täitus 125 aastat Oskar Lutsu sünnist ning samal aastal ka 100 aastat "Kevade" esmatrüki ilmumisest ning selle tähistamiseks oli planeeritud konverents ja näitus, tuli juba 2011. a. lõpukuudel alustada ettevalmistustöödega. Rändnäituse "Mälestusi kevadest" sisulise osa pani kokku Külliki Kuusk, teostus toimus koostöös Tartu Linnamuuseumi ja Oskar Lutsu Majamuuseumiga.

Lisaks näituste, ettekandepäevade ja konverentside külastajaile käib igal aastal arhiivialaseid loenguid kuulamas ning üldisemalt kogude ja arhiivitööga tutvumas arvukalt huviliste gruppe: gümnaasiumi- ja üliõpilased, muuseumi- ja raamatukogutöötajad, õpetajad, etnoloogid, genealoogid, kodu-uurijad jt. 2011. aastal registreeriti kokku 24 külastuskorda 596 inimesega, nende hulgas väljastpoolt Eestit IABA konverentsist osavõtjad, laste- ja noorsookirjanikud Hiinast, rahvusvahelise Kirjanike Muuseumide Ühenduse liikmed ning väliseestlased Austraaliast.

Kirjandus- ja kultuurilugu, arhiivikogusid ja neis sisalduvat arhiiviainest ning arhiivitöö põhiprintsiipe tutvustati ka väljaspool muuseumi - Thirlmere'i eesti külas Austraalias (Kirjandusmuuseumist ja "Kalevipojast", M. Laak); BaltHerNeti suvekoolis Käärikul (kogumisprintsiipidest ja kogumistööst, V. Asmer); Tallinna Ülikooli Rakvere Kolledžis akadeemilistel märtsipäevadel (Jüri Parijõe personaalkogust, V. Asmer ); ARSi seminar-retkel (Kodavere kihelkonnast ja vanausulistest, V. Paatsi); Eesti Ajaloomuuseumis fotoajaloo ettekandepäeval (Andres Saalist kui fotograafist ja tema pildikogust EKLAs, V. Asmer); raadios ja televisioonis (eeposest "Kalevipoeg", M. Laak). Jätkuvalt on püsinud inimeste huvi elulugude vastu ning peamiselt maakondlikes raamatukogudes pidas mitmeid selleteemalisi ettekandeid elulugude kogu hästi tundev Rutt Hinrikus. 


\section{Andmebaasid ja digiteerimine}

Eesti Kultuuriloolise Arhiivi igapäevatöös on saanud harjumuspäraseks ja väga vajalikuks pidevalt täieneva andmebaasi Ellen (http://www2.kirmus.ee:8888/ellen/avalik.do) kasutamine. EKLA fondide struktuuri ja süstematiseerimise printsiipe arvestades on selle põhifunktsiooniks korrastatud arhiivikogude nimestike ja selles sisalduvate kirjete uurijatele kättesaadavaks tegemine, misläbi oleks huvipakkuva materjali leidmine kiire ja mugav. Seisuga 31. detsember 2011 oli andmebaasi sisestatud kokku 118688 kirjet, 2011. aasta juurdekasv oli 14096 kirjet: Märt Raua, Voldemar Ermi, Peeter Lindsaare, Bernard Sööti, Otto Aleksander Webermanni, Herbert Salu, Helmi Rajamaa, Helgi Mulleri, Eduard Virgo, Mihkel Jürna, Juta Kaidla, Ado Lüüsi, Karl Mihkla, Andrus Saareste jt personaalarhiivid, ajakirja Looming, romaanivõistluste käsikirjade ja Markus Larssoni / "Ameerika Hääle" kogud ning osaliselt Eesti Komitee kogu. Fotokogudest kanti andmebaasi ajalehe Sirp pildiarhiiv. Sisestustöödega tegeles peamiselt Joel Ilja, kes tegi veebis kättesaadavaks varasematel aastatel korraldatud kogusid, aga ka kogude korraldajad ise - Johanna Ross (M. Raud, V. Erm), Mari Õunapuu (Eesti Komitee) ja Elo Maandi (Sirp). Otsingute statistilised näitajad olid 2011. a. lõpuks 19703 korda käsikirjade kogust, 6649 korda fotokogust ja 911 korda kunstikogust.

Jätkus süsteemipärane ajalehe Teataja ligikaudu 14000 säilikust koosneva pildikogu digiteerimine, millest Alar Madisson on paralleelselt tellimuste täitmise ja pildistamiste kõrval jõudnud teha umbes neljandiku ning mille lõppedes saab uurijate tellimuste lihtsustamiseks väikesed pildifailid lisada ka fotokirjetele.

2011. a. jätkus Euroopa Regionaalarengu Fondi rahastatav Eesti Kirjandusmuuseumi projekti "Eesti Trükise Punase Raamatu ja eesti kultuuri käsikirjaliste alltekstide säilivuse ja kättesaadavuse tagamine" teine aasta. Selle raames toimus ka kultuuriloolise arhiivi vanemate käsikirjaliste materjalide digiteerimine ning interneti vahendusel kättesaadavaks tegemine. Nüüdseks on digiteeritud 15 köidet Õpetatud Eesti Seltsi fondi kuuluva Võnnu 
pastori Eduard Philipp Körberi 19. sajandi algusaastate käsikirjalisest kogust ning 18-köiteline 19. sajandi lõpu ajakirjandustegelase Ado Grenzsteini kirja- ja käsikirjakogu. Digiteeritud käsikirjade säilituskohaks on selleks otstarbeks loodud failirepositoorium aadressiga http://kivike.kirmus.ee, kust faile on võimalik leida nii repositooriumi kasutajaliidese kaudu kui ka sellega seotud andmebaasidest (sh Ellen). Eelnenud aastal toimus andmebaasi Kivike testimine ja alustati EKLA materjalide andmete sisestamist koos failidega. Projekti töid teostasid Leili Punga ja Marju Mikkel.

SA Unitas toetusel toimus Eesti Muinsuskaitse Seltsi käsikirjalise arhiivi korrastamine ja ettevalmistamine digiteerimiseks TÜ Raamatukogus, töid teostasid Maarja Savan ja Marju Mikkel.

Eesti Kirjandusmuuseumi ning sealhulgas suure osana kultuuriloolise arhiivi nii käsikirjalist kui fotomaterjali hõlmab interaktiivne teabekeskkond "Kreutzwaldi sajand. Eesti kultuurilooline veeb" (http://kreutzwald.kirmus.ee, projekti juht M. Laak). Tegemist on mahuka teabekeskkonnaga, mis pakub süstematiseeritult eesti kirjanike ja kultuuriloo tegelaste isikututvustusi, teoste esmatrükke KM Arhiivraamatukogust ja arhiivimaterjale EKLAst. 2011. a. toimus keskkonna arendamine kuni aastani 1925. Projekti peaadministraator on Marju Mikkel, kes jätkas andmesisestuse ja varem alustatud Juhan Liivi käsikirjade kogu digiteerimisega, Külli Trummal tegeles projekti raames digiteeritud raamatute autoriõiguste selgitamise ja andmebaasi loomisega.

Kõige enam täienes projekt EKLA fotokogu põhjal. Arhiivist valiti, digiteeriti ja sisestati andmebaasi kirjanduslikesse või muudesse rühmitustesse ning organisatsioonidesse (nt Siuru, Tarapita, Kirjanike Liit, EÜS) kuulunud või kirjanduslikel suurüritustel (kirjanike kongressid ja väljasõidud, raamatu-aasta) osalenud isikute fotod. Töid teostasid Elo Maandi ja Alar Madisson. Üldse digiteeriti, teisendati kasutusformaati ja sisestati veebi andmeid 17 kirjandusloost tuntud isiku kohta, kokku 745 fotot ja 1983 käsikirjalehte. Projekti toetas riiklik programm "Eesti keel ja kultuurimälu"(EKKM09-94) ning isikututvustuste koostamist Kultuuriministeeriumi programm "Eesti kirjandusklassika”. Teabekeskkonna 
külastusi aastas on registreeritud ca 150 000, kasutatud 74395002 $\mathrm{kB}$ digiteeritud materjale.

Aasta 2011 oli tegus kõikidele EKLA inimestele ja seda nii teadus- kui arhiivitöö vallas. Jätkati ja viidi lópule pooleliolevad tööd ning alustati uutega, tehti plaane edasiseks. 


\section{Eesti Rahvaluule Arhiiv}

\section{Risto Järv, Mari Sarv}

2011. aastal jätkus rahvaluulearhiivi teadustöö ja arhiivitöö põimunud tegevus. Arhiivi kooseisu kuulusid arhiivijuhataja Risto Järv, sihtfinantseeritava uurimisteema juht Aado Lintrop, vanemteadurid Mall Hiiemäe (koormus 0,5, alates 11.9 koormus 0,2), Anu Korb, ja Mari Sarv, teadurid Andreas Kalkun (koormus 0,8), Janika Oras, Mari-Ann Remmel (koormus 0,25, alates 1.10 koormus 0,5), Astrid Tuisk ja Ave Tupits, projektijuht Jüri Metssalu (alates 1.03, koormus $0,5)$ ning assistendid Tuuli Otsus ja Maarja Aigro, Inge Annom (alates 1.02 koormus 0,5, alates 1.09 koormus 1,0), Jaanika Hunt (koormus 0,8), Annika Kupits, Moon Meier, Kärri Toomeos-Orglaan (alates 1.09, koormus 0,5), Siret Roots, Janno Simm, Valdo Valper (koormus 0,4, alates 1.03 koormus 0,15), Pille Vahtmäe (koormus 0,4 , alates 1.03 koormus 0,1 , alates 1.11 koormus 0,5 ). Arhiivitööd jätkasid arhivaar Kadri Tamm ja heliinsener Jaan Tamm. Töövõtulepinguga oli stuudioga pikemalt seotud Tiit Konsand.

Arhiivitöö oli jaotatud ka teadustöötajate vahel. Käsikirjakogude süstemaatilise arhiveerimisega tegeles aastal $2011 \mathrm{~K}$. Tamm, helikogu korraldamisega J. Oras, helisalvestuste töötlusega J. Tamm ning J. Hunt, fotokogu korraldamisega S. Roots ja A. Tuisk ning videokogu korraldamisega J. Simm ja K. Tamm, eksperimentaalse multimeedia-koguga M. Sarv.

Töövõtulepingutega tegid mitmesuguste projektide raames arhiivile kaastööd Katrin Hakkinen, Kaisa Kulasalu, Marika Kundla, Maris Kuperjanov, Nikolay Kuznetsov, Madli Oras, Kristi Salve, Tiina Soopa, Ene-Reet Soovik, Julia Sulina, Terje Lillmaa, Ludmila Yamuzina ja Mara Cay Woods. 
Aasta põhitulemusteks oli Andreas Kalkuni doktoritöö "Seto laul eesti folkloristika ajaloos. Lisandusi representatsiooniloole" valmimine ja kaitsmine, ning mitmete oluliste allikakogumike ilmumine. Ilmusid kohapärimuse-alased kommenteeritud allikapublikatsioonid "Metsast leitud kirik. Mõtsast löütü kerik. Urvastõ kohapärimus" ning "Päritud paigad. Kohajutte ja legende Rae vallast", ülevaatlik raamat "Pühad kivid Eestimaal" ning eesti muinasjuttude valimik prantsuse keeles. Käivitus suuremahuline "TeateTantsu" kogumise aktsioon, korraldati ulatuslikud välitööd Kullamaa ja Jüri kihelkonnas. Turgutavalt mõjus teadustöötajate ja koguhoidjate visiit Joensuusse, osalemine Ida-Soome ülikoolis rahvaluule kogumise teemalisel konverentsil ning külaskäik Joensuu rahvaluulearhiivi. Lisaks teadustööle tehti jõudumööda koostööd teiste mäluasutustega, osaleti Eesti muuseumide XIV festivalil "Teadus muuseumis", jätkati muuseumiööl osalemise traditsiooni jne. Tunnustusena aastatepikkuse viljaka töö eest pälvis Anu Korb aasta algul Eesti Kultuurkapitali aastapreemia.

2011. aastal toimus haridus- ja teadusministri 2009. aasta määruse kohaselt esimene teaduskollektsioonide perioodiline hindamine, milles hinnati perioodi 2009-2011 tegevust ja vastavust määruses kehtestatud nõuetele. Ekspertnõukogu hinnangus leiti, et Eesti Rahvaluule Arhiivi kollektsioon vastab täielikult määruses kehtestatud teaduskollektsiooni nõuetele (kolmepallisüsteemis hinne 3 ehk "eeskujulik"). Seoses teaduskollektsioonide uuenenud aruandlusega seati sisse arhiivi infopäringute register siseserveris. Tingituna ERA materjalide järjest suurenevast avaldamisest kommertskirjastuste poolt seati alates 2011. aastast sisse avaldamislepingu vorm, koostöös teiste kirjandusmuuseumi arhiividega uuendati arhiivi kasutuskorrad ja hinnakirjad.

Eesti Rahvaluule Arhiivi põhirahastus tuli jätkuvalt sihtfinantseeritavast teadusteemast "Folkloor ja folkloorikogud kultuurimuutuste mõjuväljas - ideoloogiad, kohanemine, kasutuskontekst" (juht A. Lintrop). Riikliku programmi "Eesti keel ja kultuurimälu" projektidest jätkusid "Eestlased Venemaal: asustuslugu ja pärimus" (juht A. Korb, täitmises osalesid ERA töötajatest J. Hunt, A. Kalkun, S. Roots, J. Simm, A. Tuisk ja P. Vahtmäe), "Eesti kohapäri- 
muse andmebaas ja piirkondlikud publikatsioonid" (juht M.-A. Remmel, osalesid J. Metssalu, J. Simm, J. Tamm, V. Valper, P. Vahtmäe), "Eesti regilaulude avaldamine" (juht J. Oras, osalesid I. Annom, A. Kupits). Alates 2011. aastast on kirjandusmuuseum ka seni Tartu Ülikooli poolt taotletud ühisprojekti "Eesti muinasjuttude teaduslikud väljaanded” juhtasutuseks (juht R. Järv, arhiivi poolt osalesid I. Annom ja M. Meier).

Paraku oli majanduslikult seis endiselt kehvapoolne, jätkus killustatus töötasude lappimisega eri finantsallikatest ning uute taotlemine, väikeseks rõõmuelemendiks oli see, et peatus kaks aastat väldanud teadusrahastuse vähenemine. Arhiivitööga seotud ERA töötajate koormusest kattis teaduskollektsioonide rahastus ainult väikese osa.

Arhiivitöötajate suurim mure on eri taotluste hulk arhiiviga seotud tegevuste katteks: see ületas kokkuvõttes kirjutatud teadusartiklite hulga, ühtekokku valmis arhiivi töötajatel üle kahekümne taotluse eri fondidesse, ennekõike Eesti Kultuuriministeeriumisse ning Eesti Kultuurkapitali. Vaid plaanitavad väljaanded ning nende tarbeks tehtud taotlused võimaldasid tagada kvalifitseeritud töötajate püsimiseks vajalik miinimumkoormus. Plaadiväljaande "Siberi setode laulud" ettevalmistamiseks saadi toetust rahvuskaaslaste programmist (juht A. Korb, täitjad A. Kalkun, N. Kuznetsov, A. Korb, S. Roots) ning Setumaa kultuuriprogrammist (A. Kalkun); Setumaa kultuuriprogrammist setu helisalvestuste digiteerimiseks (juht J. Oras, täitja T. Konsand); kultuuriministeeriumi programmist "Eesti kirjandusklassika" "Vana kandle" Paide ja Anna regilaulude köite avaldamiseks (J. Oras), ning Vana Võrumaa kultuuriprogrammist väljaande "Metsast leitud kirik..." trükkimiseks. Eesti Rahvuskultuuri Fondist saadi toetust RKM I seeria rahvaluulekogu digiteerimiseks (juht R. Järv, täitjad S. Roots, T. Otsus), Eesti Kultuurkapitalilt "Pro Folkloristica” numbrite I-X digiteerimiseks; numbrid VI ja IX olid varem olemas, projekti tulemusena said veebiväljaandena kättesaadavaks sarja numbrid aastatest 1993-2003 (juht R. Järv, täitjad M. Aigro, R. Järv, T. Otsus). Suuremahulise "TeateTantsu" projekti arhiveerimiseks saadi mitmeid toetusi (R. Järv, täitja M. Aigro). Mitmeid projekte 
tehti seoses rahvajuttude plaadiväljaande "Linda kivist Lilla Daamini” ettevalmistamisega (R. Järv). Stuudiotöö pingelist olukorda aitas leevendada koostöö OÜga Must, kelle tellimusel digiteeriti kommunismipärandi materjale (juht R. Järv, täitjad T. Konsand, J. Tamm) ning koostöö sihtasutusega Fennougria soome-ugri veebientsüklopeedia materjalide digiteerimisel (R. Järv, täitjad J. Hunt, T. Konsand, J. Tamm).

Arhiivi kui pärimust koguva institutsiooni järjepideva toimimise seisukohalt oleks hädavajalik süstemaatilise kogumistöö ja sellega kaasneva arhiveerimise toetamine. Kuna kogude süstemaatiliseks täiendamiseks ja töömahukateks arhiveerimisetappideks puudus jätkuvalt piisav rahastus ning frontaalset kogumistööd koos arhiveerimiskuludega ei olnud viimaste aastate tingimustes võimalik mahutada ka teadusprojektide rahastuse hulka, esitati süstemaatiliste kogumisaktsioonide läbiviimise eesmärgil riiklikule programmile "Eesti keel ja kultuurimälu” projektitaotlus "Kaasaja pärimuse kogumine, talletamine ja tekstipublikatsioonide avaldamine". Just kultuurimälu säilitamisele suunatud riiklik programm peaks oma eesmärgipüstituse poolest olema sobiv rahastusallikas rahvaluulearhiivi kogude süstemaatilise täiendamise ja kättesaadavaks tegemisega seotud töödele. Toetust taotleti ennekõike töömahukate arhiveerimistööde jaoks ning kogutud materjalide põhjal temaatiliste tekstiväljaannete koostamiseks. Kahjuks ei pidanud ekspertkomisjon taotlust piisavalt oluliseks ning jätkuvalt seisab rahvaluulearhiiv vastamata küsimuse ees, kuidas täita oma põhikirjalisi kohustusi, kui selle jaoks puudub kate.

\section{Teadustöö}

Rahvaluulearhiivi uurimisteema "Folkloor ja folkloorikogud kultuurimuutuste mõjuväljas - ideoloogiad, kohanemine, kasutuskontekst" raames jätkus uurimistöö põimituna arhiivitööde, välitööde, artiklikogumike ja teaduslike allikapublikatsioonide koostamisega. Ilmus 12 teadusartiklit, üks monograafia (dissertat- 
sioon), viis põhjalikult kommenteeritud arhiivitekstide kogumikku ja 21 populaar- või metateaduslikku artiklit. Koostati ja toimetati üks artiklikogumik ja kaks teesikogumikku. Peeti 13 ettekannet rahvusvahelistel konverentsidel ning 19 ettekannet kohalikel teadusüritustel, 6 ettekannet koolitusseminaridel. Teadustulemusi tutvustati laiemale avalikkusele mitmesugustel populariseerivatel üritustel, erialaväljaannetes ja meedias.

Andreas Kalkunil valmis doktoritöö "Seto laul eesti folkloristika ajaloos. Lisandusi representatsiooniloole" (juhendaja Kristin Kuutma) ning ta kaitses selle edukalt 30. augustil (oponendid Tiina Ann Kirss ja Thomas A. Dubois) Tartu Ülikoolis. Doktoritöö pälvis ka diplomi üliõpilaste teadustööde konkursil. Uurimuse eesmärgiks oli selgitada ja analüüsida, kuidas eesti folkloristika diskursuses on kujundatud teadmust setu laulukultuurist. Väitekirja neli peatükki kajastavad eesti folkloristika ja setu laulukultuuri kokkupuuteid eri ajastutel ja olukordades ning käsitlevad ka setu laulukultuuri representeerimise problemaatikat. Lähemalt on uuritud setu pärimusest kirjutavate teadlaste teoreetilisi, poliitilisi ja ideoloogilisi vaateid, nende kirjutamisstiili ja retoorikat, toimetamis- ja avaldamiskaanoneid ning kogumispraktikat. Uurimuse üheks taotluseks on tuua läbi representatsiooniloo kuuldavale ka setu laulikute, traditsioonikandjate endi hääl. Autor vaatleb ka seda, kuidas setu laulu on kasutatud eesti rahvusliku ideoloogia teenistuses justnagu eesti kultuuri pärli, kuid samas on jäetud tagaplaanile laulikute eneste rahvuslik kuuluvus ja eneseteadvus. Väitekirja vaatenurgad juhivad meid eesti folkloristikas seni käsitlemata aspektide juurde (eesti rahvusideoloogia, setu kultuuri ja laulikute suhestamine). Oma väitekirja tutvustas A. Kalkun ka ajakirjas RMN Newsletter.

Kahes konverentsiettekandes käsitles A. Kalkun neitsi Maarjaga seotud jutupärimust ning ühes ettekandes Fr. R. Kreutzwaldi tähelepanekuid setu kultuurist. Koos Liina Lindströmiga (TÜ) tutvustas ta 2011. aasta suvel Petserimaa setude juures korraldatud välitööde tulemusi. Populariseerivates artiklites käsitles A. Kalkun Lõuna-Eesti teadus- ja kultuurielu. 
Anu Korb pälvis Eesti Kultuurkapitali aastapreemia raamatusarja "Eesti asundused" eest, mis oli suureks tunnustuseks senitehtud tööle. Uurimused, aga veelgi enam kogutu populariseerimine on aidanud Siberi eestlasi laiemalt tutvustada. Siberi eestlaste tutvustamisnädal Torontos (näituse "Siberi eestlased" avamine, loengud, A. Korjuse filmi demonstreerimine-kommenteerimine, lugemisteatri Ilutuli etendus A. Korbi koostatud raamatu põhjal) oli ülimalt vajalik, et murda sealsete eestlaste väärarusaamu Siberi eestlaste kohta. Pikaaegne kogumistöö Siberi eestlaste juures on päästnud hulga unikaalset materjali unustuse hõlma vajumast.

Ka A. Korbi 2011. aastal peetud konverentsiettekanded ja ilmunud artiklid käsitlesid eesti idadiasporaa kogukondi - pärimuse kogumist Siberi eestlaste juures, Siberi eestlaste laulurepertuaari kujunemist multikultuurses keskkonnas ning Venemaal sündinud eestlaste Eestisse naasmist ja kohandumist siinsete oludega. Populariseerivates artiklites, tele- ja raadioesinemistes käsitles A. Korb Siberi eestlasi üldisemalt, nende elulugusid, Siberi eesti külasid tutvustavat näitust, aga ka kõrvutavalt ida- ja läänediasporaa kogukondi ning Siberi rahvuskaaslaste ajaloo ja kultuuri tutvustamist Kanada eestlastele.

Siberi eestlaste pärimuse uurimist jätkas ka Astrid Tuisk, kellel ilmus artikkel väljarändamislugudest, mida on rääkinud Eestist läinute järeltulijad. Artiklis vaadeldakse, milliseid pilte maalivad praegused jutustajad väljarändamise-eelsest (orja)elust Eestis, millise ideoloogilise tähenduse need on omandanud, ning näidatakse, kuidas kollektiivne mälu tugineb traditsioonile rääkida konkreetsest sündmusest või ajalooperioodist ühes kindlas võtmes. Koos Aivar Jürgensoni ja Kaja Kumer-Haukanõmmega kirjutatud artiklis vaadeldakse eesti migratsioonilugu vabatahtlikkuse ja sunniviisilisuse aspektist lähtuvalt. A. Tuisk jätkas ka veebilehe internetilehekülje "Siberi- ja Volgamaa eestlased" täiendamist - veebilehele lisati kaart, fotosid, video- ja helinäiteid, nende tööde juures abistas P. Vahtmäe. A. Tuisu doktorantuuriõpingud Tartu Ülikooli juures keskenduvad lastepärimusele ning sel teemal pidas ta ka kaks ettekannet lasteaednike eesti keele koolitusseminaril. Kahes konverentsiettekandes käsitles A. Tuisk rahvaluule kogumise ja kogude 
haldamisega seotud problemaatikat ning koostas ülevaate arhiivile 2010. aasta jooksul laekunud kaastöödest.

Mari Sarvel ilmus kaks värsimõõdu-alast artiklit rahvusvaheliste meetrikakonverentside kogumikes, ühes neist käsitles ta suulise luule värsimõõdule universaalselt iseloomulikke tunnuseid, teises artiklis analüüsis eesti regilaulu värsimõõdu piirkondlike eripärade võimalikku lähtumist etnilistest kontaktidest nii kultuuri- kui keelemõjude kaudu. "Kalevipoja" esmailmumise 150. aastapäevale pühendatud konverentsil peetud ettekandes käsitles M. Sarv kalevipojavärsile iseloomulikke poeetikatunnuseid võrdluses regilauluga ning analüüsis kalevipojavärsi hilisema eduka leviku põhjusi. Kullamaa välitöö-ekspeditsiooni kavandades ja hiljem selle tulemusi tutvustades keskendus M. Sarv kodupärimusele, leides, et kui kohapärimust uurides on märgatud inimese ümber oleva maastiku "tähendustega laetust", siis sama ja ehk veel enam kehtib kodu, eriti põliskodu ja selle lähiümbruse kohta, kus esemete ja kohtadega seostuvad (mikro)lood, mälestuskillud, aga teinekord ka aegade taha ulatuvad muistendid. Konverentsiettekandes käsitletud isikupärimuslike lugude puhul näitas ta, et rahvapärasele jutustamisele iseloomulik detailide varieerimine, asendamine, juurdepanemine toimib sellisena ka ajaloolise tõena räägitavate lugude juures ning ajalooline tõde võib seejuures moonduda tundmatuseni; samal ajal ei teki ükski lugu tühjale kohale, lood vahendavad alati mingi teatud osa sellest ajaloolisest tõest, mingid detailid või kasvõi lugudes väljendatud hoiakud, suhtumised sündmustesse või inimestesse on ikka tõesed. Kahes konverentsiettekandes tutvustas M. Sarv ka rahvaluulearhiivi kogusid ning digitaalarhiivi arendustöid.

Ave Tupits tegeles aasta jooksul nii rahvameditsiini ajaloo kui ka teatripärimuse kogumise ja uurimisega. Ajakirjas JEF ilmunud artiklis käsitles ta Eesti Tervishoiumuuseumi direktori Voldemar Sumbegi seisukohti rahvameditsiini ja akadeemilise meditsiini vahekorrast ning tema 1920.-1930. aastatel läbiviidud rahvameditsiini kogumisaktsioone, samuti kogutud materjalide saatust. Eesti rahvameditsiini kogumis- ja uurimislugu maailmasõdade vahelisel ajal käsitles A. Tupits ka ühes konverentsiettekandes. SIEFi kongressil pidas A. Tupits ettekande teatripärimuse kogu- 
mise strateegiatest. Enesekohase vaatenurgaga rääkis ta probleemidest, kuidas läheneda suhteliselt suletud kogukonnale, seal ennast kehtestada ja panna inimesed avameelselt rääkima folkloristi huvitavatel teemadel. Erialaajakirjades tutvustas A. Tupits eesti folkloori kogumislugu, rahvaluulearhiivi ning Akadeemilise Rahvaluule Seltsi tegemisi ja toimunud folkloristikaüritusi.

A. Tupits korraldas koos Marleen Nõmmelaga Eesti Rahva Muuseumist 27.-28. aprillil traditsioonilise noorteadlaste konverentsi "Noorte hääled", mis juba mitmendat aastat toimub ERA ja ERMi ühisettevõtmisena. Konverents on tudengitele ja kraadiõppuritele heaks võimaluseks tutvustada oma uurimistulemusi laiemale teadlaskonnale ning oma esinemisoskusi proovile panna. Konverentsil osales paarkümmend esinejat, sh välistudengid TÜst. Konverentsi raames toimus ka möödunud aasta noorteadlaste konverentsi artiklikogumiku "Kuldkalake. Pro Folkloristica XVI" - toim. A. Tupits, Kanni Labi (EO) - esitlus. A. Tupits ja K. Labi olid ka konverentsi teesikogumiku ERA-poolseteks toimetajateks.

Assistent Jaanika Hunt analüüsis konverentsiettekandes tänapäevases popkultuuris käibivate surmakujundite päritolu- ja levikuteid, täheldades massimeedia trendeloovat ja suhtumisi kujundavat rolli selles. Oma uurimusele tuginedes tõdes J. Hunt, et tänapäevased uskumused on pluralistlikud, igal inimesel on modernses infoühiskonnas võimalus luua endale oma isiklik uskumussüsteem, kasutades eri rahvaste folkloori ja religiooni ning segades neid omavahel sõltuvalt enda kogemustest ja tajudest.

Janika Orase teadustegevus keskendus rahvalaulu muusikalisele küljele. JEFis ilmunud artiklis analüüsis ta regilauluesituste põhjal teksti struktuursete üksuste markeerimist spetsiaalsete viisivariantidega. Nelja lauliku regilauluesitusi analüüsides jõudis ta tulemusele, et tekstis sisuliselt uusi osi sissejuhatavad värsid on markeeritud nii tavapärasest pisut silbirohkema värsistruktuuri, aga ka "intensiivsema", silmatorkavama meloodiavariandiga. Aasta jooksul tegeles J. Oras ka intensiivselt Olli Kõiva koostatava "Vana kandle" Paide ja Anna köite toimetamisega. Samasse väljaandesse kirjutas ta Paide ja Anna kihelkondade regiviiside ülevaate, kus otsis võimalust, kuidas kirjeldada väikest ja sisuliselt väga hajusat 
viisikogumit, ning tõi esile uuemaaegse muusika mõjusid taandumisperioodi regilauludes. SIEFi kongressil peetud ettekandes analüüsis J. Oras I maailmasõja aegsetelt sõjavangidelt salvestatud laulude esitusstiili ja laulukogumi kultuuriajaloolist tähendust folkloorikogude ja kultuurmuusika salvestuste kõrval. Koolitusseminaridel tutvustas J. Oras väikelastele sobivaid regilaule ning elulugude ja rahvaluule seoseid. Viimaste aastate regilauluviiside uurimise tulemusi on J. Oras praktiliselt rakendanud regilaulude õpetamisel nii Eesti Muusika- ja Teatriakadeemias kui mitmetes õpitubades. Arhiivi, selle materjale ja kogumistööd on J. Oras tutvustanud ka populariseerivates ülesastumistes ja meedias.

Teadusteema juht, vanemteadur Aado Lintrop jätkas uuringuid soome-ugri rahvaste mütoloogia ja usundi alal. Lisaks soome-ugri temaatikale käsitles A. Lintrop ühes konverentsiettekandes ja pikemas loengus Omskist umbes 250 kilomeetrit põhja pool Tara jõe kaldal asuvast väikeses külas Okunjovos 1992. aastal tekkinud usukogukonda ning sellega seotud kuuldusi küla all maa sees olevast templist, mõttekristallist ning meteoriidi kokkupõrkest Maaga tekkinud järvede imeliste omadustega veest. A. Lintrop näitas, kuidas meediat ja internetti kasutatakse uute uskumuste loomiseks ja kehtestamiseks, usutavuse suurendamiseks viidatakse sageli teadlastele ja nende avastustele. Meedia vahendusel on Okunjovost saanud palverännakute sihtpunkt, kus toimetavad oma rituaale lisaks erilise koha avastanud (või loonud) müütilise guru Šri Babaji jüngritele uuspaganad, vanausulised ja õigeusklikud.

Mall Hiiemäe suuremaks tööks 2011. aastal oli kommenteeritud tekstivalimiku "Pühad kivid Eestimaal" koostamine. Rohkete fotodega varustatud raamat annab ülevaate eestlaste kivipärimusest rändrahnudega seotud lugudest ja uskumustest. Erialaajakirjanduses tutvustas M. Hiiemäe veel P. Voolaiu doktoriväitekirja eesti mõistatuste perifeersetest alaliikidest ning populaarsetes väljaannetes nahkhiire ja suitsupääsukese kohta kirja pandud folkloorseid teateid. M. Hiiemäe oli ka 55. Kreutzwaldi päevade teesikogumiku toimetajaks. Mitmetes avalikes ülesastumistes tutvustas M. Hiiemäe eesti loodus- ja kalendripärimuse eri aspekte. 
Moon Meier uuris rahvapärast jutuvestmist Eestis ja Ungaris. Ilmunud artiklis ja konverentsiettekandes käsitles M. Meier oma süvaintervjuu põhjal Ungari jutuvestja András Bereczi maailmavaadet: veendumusi ja seisukohti, suhtumist keelesse, moodsasse ühiskonda, pärimusse, lugudesse ja jutuvestja rolli; samuti jutuvestmiseetikat, mis sellest veendumuste kogumist on sündinud. Oma kokkupuudete põhjal mitmete maade jutuvestjatega väidab autor, et sarnased seisukohad on meile iseloomulikud üldisemalt ning kõnelevad paljuski kogu tänapäevasest jutuvestmisliikumisest. Muinasjutuseminaril peetud ettekandes käsitles M. Meier setu jutuvestja Terje Lillmaa arvamusi, suhtumisi ja jutuvestmispraktikat.

Inge Annom tegeles 2011. aastal lisaks muinasjuttude sisestustööle suuresti veebikogumiku "Pühakud ja vägimehed. Muinasjutte Lutsi maarahvalt ja nende naabritelt” ettevalmistamisega seotud töödega - tegi esmase tüübivaliku, tõlkis lutsi- ja venekeelsed muinasjututekstid. Obinitsas toimunud seminariettekandes käsitles I. Annom Paulopriit Voolaine tööd Lätimaal asuva Ludza piirkonna pärimuse jäädvustamisel ning sealse eesti keelesaare säilitamisel.

Kohapärimuse töörühma assistendil Valdo Valperil ilmus pikaajalise kogumis- ja koostamistöö tulemusena põhjalik raamat Urvaste kohapärimusest (toim. M. Hiiemäe). Raamatu saateartiklis tutvustab autor raamatu koostamislugu ja -põhimõtteid ning annab ülevaate nii Urvaste kohapärimuse kogumise ajaloost kui ka pärimuslugudega seotud kohaliikidest (ehitised, loodusobjektid, teed, jõed jts). Raamatu põhisisu moodustavad arhiividest leitud pärimustekstid, mida oluliselt täiendavad autori enese välitöömaterjalid. Ka on püütud välitöödel lugude aluseks olevaid kohti võimalikult täpselt tuvastada. Raamatus leidub ka rikkalikult fotosid pärimuspaikadest nii varasematel aastatel kui tänapäeval. V. Valper tutvustas ERA kohapärimuse töörühma tegevust ka avalikel esinemistel.

Kohapärimuse töörühma töö tulemusel ilmus 2011. aastal veel teinegi raamat, Mari-Ann Remmeli koostatud "Päritud paigad. Kohajutte ja legende Rae vallast” (toim. K. Tamm, Heiki Valk, V. Valper), mis on pühendatud Rae valla 145. aastapäevale ning 
on valminud sealse vallavalitsuse tellimusel ja osalt ka rahastusel. Sarnaselt Urvaste raamatuga sisaldab teos valiku lugusid praeguse Rae valla alal säilinud muististest ja pärimuspaikadest: pühapuudest ja hiiesaludest, ohvrikividest ja kalmetest, veekogudest ja ehitistest. Kohalikelt elanikelt talletatud legende, muistendeid ja mälestusjutte täiendavad eriaegsed fotod pärimusobjektidest ja põliselanikest. Rahvusvahelises keskkonnafilosoofiale ja maastikumõttele pühendatud artiklikogumikus (UTKK) uurib M.-A. Remmel rahvajuttude sotsiaalseid tagamaid, kõrvutades omavahel mõisa- ja hiiepärimust ning nende lõikumispunkti - lugusid mõisnike suhtumistest hiitesse. Oma artiklis näitab Remmel, et lood ei järgi ühesuunalist kollektiivset kujutelma mõisnikest eestlaste hiite hävitajaina. Negatiivsed lood on pigem anonüümsed ja muistendilaadsed. Mitmed konkreetsemad, pajatuslikud teated annavad meile aga hoopis teada "valgustatud" mõisnikest, kes kohati kaitsesid muinsusi suuremagi tähelepanu ja teadlikkusega kui talupojad. M.-A. Remmel tutvustas pärimuspaiku, nendega seotud lugusid ja uskumusi ka populaarsetes kirjutistes ja esinemistel.

Arhiivijuhataja Risto Järve teadustöö keskendus põhiliselt muinasjuttudele, valmis kaks muinasjututekstide väljaannet prantsuskeelne kommenteeritud eesti ja setu metsamuinasjuttude valimik "L'Esprit de la foret: contes estoniens et seto" Eva Toulouze'i tõlkes ning muinasjuttude töörühma ühistööna valminud kommenteeritud internetiväljaanne "Pühakud ja vägimehed. Muinasjutte Lutsi maarahvalt ja nende naabritelt". Samuti ilmus koos Mari-Liis Tammiste ja Kristi Salvega toimetatud Uku Masingu folkloristika-alaste artiklite kogumik "Aarded tellistes". Jätkus töö muinasjuttude tüpoloogia korrastamise ja monumentaalväljaande ettevalmistamisega. Konverentsiettekannetes käsitles R. Järv mitmeid eri teemasid: turistikogemuse ajatunnetust (ühisettekanne Maarja Kaaristoga), rahvapärimuse kasutamist turismitööstuses, folkloorseid strateegiaid reklaamides, Kalevipoja-eelset eesti mütoloogiat ja selle kajastusi Eesti varasemas folkloorikäsitluses Kr. J. Petersoni poolt, ning Setumaal levinud muinasjututüüpi "Ussi naine" (ATU 425M). Kirjandusmuuseumi kogumisstrateegiatest 
pidas R. Järv ettekanded vaimse kultuuripärandi koolitusseminaril Tallinnas ning Soomes Joensuus välitöö-alasel konverentsil.

\section{Teadusüritustel osalemine}

Eesti folkloristide 6. talvekonverentsil Jõgevestes (3.-4.02) esines ettekandega "Vanad lood uues kuues: maailma nabast, okunevo kristallist ja populaarsest vodkamargist" A. Lintrop.

A. Korb pidas Baltimaade diasporaauurijate vorrgustiku BaltHerNet noorteseminaril (10.02) ettekande Siberi eestlaste elulugude kogumisest ja publitseerimisest ning osales ka võrgustiku BaltHerNet suvekooli korraldamisel.

A. Lintrop esines Eesti Akadeemilise Usundiloo Seltsi loengusarjas "Religioonid ja ühiskonnad II" (17.02) teemal "Usundid kohtuvad Okunjovos. Üks religioosse sünkretismi näide kaasaegsel Venemaal".

Eesti Rahva Muuseumi, Eesti Kirjandusmuuseumi ja ühenduse "Eesti elulood" koolitusseminaril (21.02) "Kuidas koguda mälestusi ehk mida teha elulooga?" pidas J. Oras ettekande "Rahvaluule ja elulugu".

Indias, Shillongis toimunud ISFNRi konverentsil (22.-25.02) osalesid R. Järv ettekandega "Older and Newer Folktales in the Practice of Tour Guides on the Island of Hiiumaa" ja A. Kalkun ettekandega "Virgin Mary and Seto Identity: On the role of virgin Mary in Seto women's Belief Narratives".

Urvaste kohapärimuse väljaande esitlusel Võru Instituudis (11.03) esines M. Hiiemäe ettekandega "Kohapärimus folkloristika mõistena".

Rahvusvahelise Etnoloogide ja Folkloristide Ühenduse (SIEF) kongressil "People make places - ways of feeling the world" Lissabonis (17.-21.04) osalesid J. Oras ettekandega "Recordings from WWI war prisoners as a representation of Estonian singing culture" ja A. Tupits ettekandega "The Field of Theatre". 
Eesti Muuseumiühingu ja Rahvakultuuri Arendus- ja Koolituskeskuse koolitusel "Vaimse pärandi küsimused muuseumis" (26.27.04) esinesid R. Järv ettekandega "Vaim ja selle püüdmine. Eesti Kirjandusmuuseumi kogumispraktikatest" ja A. Korb ettekandega "Allikate loomine välitööl ning kogutu kasutamine".

Konverentsil "Noorte hääled" pidas (28.04) ettekande "Surmakujundid popkultuuris" J. Hunt.

Budapestis toimunud rahvusvahelisel soome-ugri tudengikonverentsil IFUSCO (10.05) pidas M. Meier ettekande "Storytelling on Stage: The Attitudes and Role of Hungarian Storyteller András Berecz".

M. Hiiemäe esines Eesti Teaduste Akadeemia Looduskaitse komisjoni 49. ettekandepäeval Tartus (25.05) ettekandega "Loodushoiu usundiline taust".

M. Sarv pidas koos Kadri Tüüriga (AR) mäluasutuste suveseminaril "Digitaalse ressursi strateegiad ja kompetentsikeskused" (31.08) ettekande "Digitaalsest kultuuripärandist Eesti Kirjandusmuuseumis”.

TÜ Lõuna-Eesti keele- ja kultuuriuuringute keskuse seminaril "Lõunaeesti sõnaraamatud" (30.09) pidas A. Kalkun koos L. Lindströmiga ettekande "Petserimaa setosit kaemah: keelest ja meelest".

Soome antropoloogide aastakonverentsil "Dynamic Anthropology: Tensions between Theory and Practice" (6.10) Helsingis pidas R. Järv koos Maarja Kaaristoga (TÜ) ettekande "Our clock moves at a different pace: the timescapes of identity in Estonian rural tourism".

Seminaril "Seto muinasjutud ja Lutsimaa pühakud" Obinitsa Seto Muuseumitarõs (8.10) esinesid M. Meier ettekandega "Terje Lillmaa seto jutuvestjana”, A. Kalkun ettekandega "Pühä Maarja ja seto identiteet. Jumalaema kohast seto juttudes", R. Järv "Muinasjutt "Ussi naine" (ATU 425M)" ning I. Annom "Paulopriit Voolaine ja Lutsimaa”. 
SIEFi rituaalse aasta töörühma 7. konverentsil "Researchers, Performance, Researcher; Co-Designing Heritage, Co-Designing Performance" Ljubljanas (10.-13.10) pidas A. Lintrop ettekande "The Great White Leader Visits the Northern Shaman".

Eesti Muusikakogude Ühenduse asutamise 20. aastapäeva konverentsil (27.10) pidas M. Sarv ettekande "Heli- ja muusikakogud Eesti Rahvaluule Arhiivis".

Akadeemilise Rahvaluule Seltsi kogumiskonverentsil "Eetika ja valikud" (27.10) pidasid M. Sarv ja A. Tuisk ettekande "Frontaalse kogumistöö valikud - ERA Kullamaa-välitööd 2011”. M. Meier pidas koos Jaan Sudakuga (TÜ) ettekande "Ammutame või anname?".

Balti Kirjandusteadlaste 9. rahvusvahelisel konverentsil "From Past to Present: Transformations of Memory in Contemporary Culture" (28.10) Tallinnas pidas M. Sarv ettekande "There's a Grain of Truth in Every Story".

Poolas, Krosnos korraldatud konverentsil "Creativity and Tradition in Polish and Estonian Cultural Communication" (28.10) pidas R. Järv ettekande "Traditional texts in advertising".

Joensuus toimunud konverentsil "Kenttien kutsu. Kenttätutkimus ja keruu tämän päivän perinteen- ja kulttuurintutkimuksessa" (10.-11.11) pidas R. Järv ettekande “"Paljonko on tarpeeksi?" Kenttätyöt ja tallennetun aineiston arkistointi Viron kirjallisuusmuseossa".

"Kalevipoja" ilmumise 150. aastapäevale pühendatud konverentsil "Traditional and Literary Epics of the World: Textuality, Autorship, Identity" (29.-30.11) pidas M. Sarv ettekande "The Success Story of a Verse Form" ning R. Järv ettekande "Construction of 'Pre-Kalevipoeg': K. Ganander/K. J. Peterson's Finnische Mythologie".

Lasteaednike eesti keele koolitusseminaril Tartus (17.-18.11) pidas A. Tuisk ettekanded "Innovatsioonist ja traditsioonist lastepärimuses" ning koos Piret Voolaiu ning Merike Lilloga ettekande 
"Liisklugemised ja lõbusad riimid lastepärimuses". J. Oras pidas ettekande "Rahvalaulud väikelastele".

Siseministeeriumi ja kohanimenõukogu IX kohanimepäevadel Jõhvis (2.12) esines M. Hiiemäe ettekandega "Kohanimed ja rahvapärimus".

Tartu Ülikooli Ajaloo muuseumis toimunud konverentsil "Miks ja kuidas eksponeerida akadeemilist pärandit? Ülikoolimuuseumi roll tänapäeva Euroopas.” (6.12) pidas A. Tuisk koos Kadri Tüüriga (AR) ettekande "Teaduskollektsioonid Eesti Kirjandusmuuseumis. Lilla Daam ja virtuaalne kelder”.

21.-22. detsembril toimunud Kreutzwaldi päevadel esinesid A. Kalkun ettekandega "Eesti oma terra incognita. Kreutzwald seto kultuuri vahendamas" ja A. Korb ettekandega "Diasporaa eestlaste kohanemisest asukohamaal kogutud pärimusainese põhjal".

A. Korb käis tutvustamas materjale Siberi eestlaste kohta Kanadas eesti läänediasporaa kogukonnale, Toronto Tartu kolledži hooaja avamisel avati näitus Siberi eestlastest ning A. Korbi kogutud ja avaldatud materjalide põhjal oli lugemisteatril "Ilutuli" valminud näidend Siberi eestlastest.

\section{Kogumistöö}

Eesti Vabariigi Presidendi rahvaluule kogumispreemia kätteandmine toimus seekord emakeelepäeval 14. märtsil 2011. a. Möödunud aasta kogumistöö eest anti üle kolm preemiat - need pälvisid Maire Sala (Karksi-Nuia) uuema aja matmiskombestiku ja kalmistukultuuri talletamise eest, Anni Oraveer (Haapsalu) Eesti pimedate kogukonna pärimuse ja setu murdejuttude talletamise eest, ning Ellen Randoja (Palamuse) Põhja-Tartumaa rahvalaulude ja -juttude ning Teise maailmasõja aegse ja järgse, samuti kolhoosipärimuse ning kohalikelt inimestelt värvikate pajatuste ja pilalugude kogumise eest. 
2011. aastal saabus arhiivi kokku enam kui 8000 lehekülge käsikirjalist materjali. Rahvaluule kogumistöö eest esitati Vabariigi Presidendi kogumispreemia saajateks kokku neli inimest: Leelo Kund, Margit Korotkova, Triin Kusmin ning Age-Kristel Kartau.

Leelo Kund ja Margit Korotkova (MTÜ Koostöö- ja arenduskoda Võhandu) andsid Eesti Rahvaluule Arhiivile üle oma Setumaa välitöödel (2008-2010) Räpina ja Mikitamäe vallas kogutud ja korrastatud ning andmetega varustatud materjalid: $277 \mathrm{lk}$ digitaalset teksti, 217 digifotot, 61 helifaili intervjuudega ja 6 videofaili. Intervjueeriti 58 kohalikku elanikku. Projekti nimetusele vastavalt oli vestluste keskmes usund ja kombestik (kirikuelu ja kogudused, rahvauskumused, pühadekombed jne), kuid koguti ka muud pärimust ja saadi biograafilisi andmeid.

Riikliku Metsamajanduskeskuse loodushoiuosakonna pärandkultuuri spetsialist Triin Kusmin on seotud olnud aastatel 20052011 toimunud RMK pärandkultuuri inventeerimise projektiga "Metsanduslik pärandkultuur - ühise kultuuriruumi avardaja". Ta on salvestanud ning arhiivile üle andnud Lääne-Virumaa (Vihula valla), Läänemaa (Nõva valla), Tartu- ja Võrumaa (Kanepi, Kiidjärve) elanikelt kogutud kohapärimuslikku ja eluloolist materjali, lisaks pärimuslikku ainest külaelust ja andmeid vanadest töövõtetest. Eriline tähelepanu on tema kaastöödes olnud metsa ja metsatööga seonduval pärimusel. Põhjalikult on küsitletud eluaegset metsameest ja loodusharidustegelast Ain Erikut Kiidjärvelt. Kokku on materjali 23 tundi, lisaks salvestuste litereeringud.

Age-Kristel Kartau on magistriõpingute aastate jooksul (20082010) salvestanud ametipärimusliku suunitlusega biograafilist ja alternatiivmeditsiinilist materjali (Tai massaaž ja selle viljelejad Eestis). Kokku on Age-Kristel Kartau 2010. ja 2011. aastal arhiivile üle andnud 48 tundi helisalvestisi ja nende salvestuste litereeringuid $300 \mathrm{lk}$ ulatuses.

Käsikirjalised kogud. Aasta jooksulERAle üle antud mahukamad ja sisukamad kaastööd olid Setumaal 2010. a toimunud välitööde materjalid (projektijuhid Leelo Kund ja Margit Korotkova); Jõelähtme valla külades välitöödel kogutud salvestuste litereeringud 
(peamiselt kohapärimus, projektijuht Triin Äärismaa); kodu-uurija Oskar Raudmetsa (1914-2003) käsikirjad (Harjumaad puudutavad folkloorsed kirjapanekud, 249 lk); Anni Oraveere kogutud pimedate pärimus ja murdejutud (180 lk); õpilaste jutuvõistluse "See juhtus Toomemäel” tööd (84 lk, projektijuht Epp Nõges, Tartu linnaraamatukogu); Vassili Kolga pärand (laulud, Simiste küla ajaloo alane materjal jm, üleandja tütar Esperinda Meikar); Jõgeva jõuluvana postkontori kirjad 2009-2010 (üleandja Eleene Sammler).

Helikogu. Kogusse laekus 2011. a materjali kokku 156 tundi. Üle poole sellest koguti ERA Liivi-Kullamaa ekspeditsioonil ning väiksem osa EMTA tudengite ekspeditsioonidel Kihnusse ja Setumaale, TÜ tudengite ekspeditsioonil Kihnu ja ERA kohapärimuse töörühma ekspeditsioonil Jüri kihelkonda. Materjali laekus ka teatrifolkloori projekti raames (u 24 tundi).

Fotokogu. Aastal 2011 laekus arhiivi üle 3500 digifoto, millest seerias ERA, DF võeti arvele ja infosüsteemis kirjeldati 2014 fotosäilikut. Abitööjõudu kasutades lõpetati mustvalgete fotode (seeria ERA, Foto) fotonimestike sisestamine ja alustati varem sisestatud metaandmete kontrollimist. Suuremateks laekumisteks olid Aado Lintropi fotod Setumaalt (üle 700 digifoto), Helen Alumäe pulmafotod (748 digifotot), fotod pillimeestest (üleandja Üllar Kurik, 71 fotot), Räpina pärandkultuuri objektide fotod (üleandja Janne Eespäev, 1310 digifotot). Lasteaiapärimuse kogumisvõistlusele laekus 388 digi-, 105 värvi- ning 40 mustvalget fotot.

Videokogu. Videokogus võeti arvele 81 säilikut. Suuremad ja sisukamad laekumised olid: jäädvustus Egle ja Peeter Veltmanni pulmadest (12 säilikut, üleandja Peeter Veltmann, filmija Arvo Vilu); Kullamaa välitööde filmimaterjal (5 säilikut, filmija A. Tuisk ja kohalikud kogujad); Taisto-Kalevi Raudalaise Ingeri välitööde 2010. a materjal (15 säilikut); Tartu laste rahvamuusikapäeva "Taaralinna taaderant" videod eri aastatest (9 säilikut, üleandja Tiina Konsen); J. Orase ja EMTA tudengite välitööde materjal (3 säili- 
kut peamiselt Kihnust ja Setust); 2011. a Viljandi pärimusmuusika festivalil filmitu (3 säilikut, üleandjad A. Lintrop, J. Hunt, Sille Kapper ja Anna Zubkova). Digitaalvideotest arhiveeriti lõplikult ja varustati WMV töökoopiatega 47 tunni jagu kõrgresolutsiooniga videomaterjali (ERA, EV 54-64, 68, 82).

Kogumisaktsioonid. Aasta suurimaks kogumisaktsiooniks oli "TeateTants", augustis 2011 üle Eesti toimunud teatetantsimine, millega seoses talletasid tantsurühmad aasta jooksul "teatepulgale" ("mälupulgale" resp. mälukaardile) oma rühma kohta käivat pärimust. Kogumine viidi läbi koostöös Eesti Rahvatantsu ja Rahvamuusika Seltsiga. Küsitluskava koostati talvel (R. Järv, K. Tamm, A. Tuisk, A. Tupits) ning kogumisvõistlus kuulutati välja 1. märtsil. Kokku laekus arhiivi enam kui 3000 tinglehekülge tekstina ning 13600 fotot. Sügisel võeti mälukaardid arvele ja suheldi tantsugrupi juhtidega nimekirjade täpsustamiseks, võeti ühendust 126 tantsujuhiga ning küsiti kommentaare materjali juurde (M. Aigro, K. Tamm).

Alates detsembrist 2010 kuni märtsini 2011 toimus lasteaiapärimuse kogumise võistlus, mille peakorraldajaks oli Piret Voolaid KM folkloristika osakonnast, rahvaluulearhiivi poolt aitas materjali arvele võtta M. Meier, žüriis osales A. Tuisk. Küsitluskavale vastas ligi 80 õpetajat-kasvatajat lasteaedadest üle Eesti.

Välitööd. Rahvaluulearhiivi korraldusel toimus kaks mahukamat välitööd. Jätkusid välitööd Kullamaa kihelkonnas, sedapuhku peatuspaigaga Liivil 13.-19. juunil (korraldaja M. Sarv). Osalesid T. Otsus, K. Tamm, A. Tuisk, P. Vahtmäe, V. Valper, Epp Tamm; lühiajaliselt ka R. Järv ja J. Metssalu. Välitööde üheks eesmärgiks oli jäädvustada kodupärimust, vastava küsitluskava koostas M. Sarv. Välitööde järel korraldas M. Sarv kodupärimuse visuaalsete aspektide jäädvustamiseks täiendava pildistamisretke koos fotograaf Margus Vilisooga. M. Sarv kogus Kullamaa pärimust ka paaril päeval jaanuaris. 
Kohapärimuse rühm käis välitöödel Jüri kihelkonnas mitmel korral (juht M.-A. Remmel) seoses raamatu "Päritud paigad. Kohajutte ja legende Rae vallast” ettevalmistamisega. Osalesid J. Metssalu, P. Vahtmäe, V. Valper. Lühiajalistel välitöödel Räpina kihelkonnas käis V. Valper.

Jätkus 2010. aastal alanud teatripärimuse kogumine koostöös TÜ üliõpilastega (projektijuht A. Tupits, ERAst osales ka M. Meier). Kahe aasta jooksul koguti põhiliselt Pärnu Endla ja Tallinna Linnateatri, samuti Estonia endistelt ja praegustelt töötajatelt kokku 100 tundi heliainest, mõned intervjuud tehti e-posti teel, samuti koguti kaks tundi videomaterjali teatriekskursioonist.

Koostööprojektide käigus ja lähtuvalt enda uurimishuvist osaleti mitmetel välitöödel. J. Oras juhendas EMTA üliõpilaste välitöid Kihnus ja Setumaal. J. Hunt osales Sihtasutuse Rebala Fond välitöödel Jõelähtme kihelkonnas, M. Meier osales TÜ välitöödel Kihnu saarel, A. Kalkun käis välitöödel Petserimaal (nii TÜ poolt korraldatud matkal kui ka iseseisvalt). A. Tuisk on aasta jooksul kirjeldanud, pildistanud ja filminud laste rollimänge. A. Korb intervjueeris Venemaal sündinud eestlasi. A. Kupits filmis jüripäeva kirmast Värskas. J. Oras ja A. Lintrop salvestasid pulmade pidamist Pärnumaal Treimanis ning Viljandis; J. Oras organiseeris ka pulmade jäädvustamise Saardes ja Torupillitalus Riidajal.

A. Lintrop pildistas aasta jooksul mitmesuguseid tähtpäevi ja sündmusi Setumaal alates talsipühadest kuni Lindora laadani, arhiveerimisele tuli 1088 fotot. Samuti jäädvustas Lintrop Viljandi pärimusmuusika meestelaulutuba, regilaulupesa ja tänavatel musitseerimist; lisaks veel setu laulu ansambli Liinatsuraq ja teiste kollektiivide esituses.

J. Oras filmis ansambli Tsibihärbläsed 25. aastapäeva pidu Obinitsas, Vabaõhumuuseumis EMTA tudengitele vanade tööde õpetamist ning setu laulu laulmist, Seto kuningriigi päeva meestelaulu ja sõnolise võistlust ning lasteaia kevadpidu.

Enamik arhiivi teadustöötajatest korraldas ja andis aasta jooksul üle ka senikogutud materjali, nõustati arhiivi külastavaid uurijaid. 2011. aastal oli rahvaluulearhiivis külastajaid külalisteraamatu 
põhjal 525, arvukalt tehti lisaks päringuid telefoni ja e-posti teel. Peale uurijate külastas arhiivi aasta jooksul 31 arhiiviekskursiooni käigus 721 inimest.

\section{Töö arhiivimaterjalidega, arhiveerimine ja materjali kättesaadavaks tegemine}

Digiteerimine. Kõige olulisemaks digiteerimistööks rahvaluulekogude seisukohalt 2011. aastal oli Jakob Hurda rahvaluulekogu digiteerimine (töö algas juba 2010. aastal). Digiteerimise ettevalmistustööde raames kirjeldati Jakob Hurda rahvaluulekogu köidete seisund, vormistati töölehed. Tarvilikud köited restaureeriti OÜ Mandragora poolt, digiteerimistöö toimus Tartu Ülikooli raamatukogus. Skaneeritud failid kontrolliti, varustati arhiiviviidetega ning paigutati kirjandusmuuseumi failihoidlasse Kivike. 2011. aasta jooksul lisandus 20213 käsikirjalehekülge (35 Hurda kogu köidet) ning digiteeritud sai enamik Jakob Hurda kogust (105390 $1 \mathrm{k})$.

Alustati tööd käsikirjakogu RKM I materjalide skaneerimisega: aasta lõpuks sai digiteeritud 12 säilikut (6115 lk), failid tehti kättesaadavaks failihoidlas Kivike 2012. aasta I poolel.

2011. aastal tehti kasutuskoopiad kõigist aastail 2005-2010 laekunud digikäsikirjasäilikutest (46 säilikut, kokku 5043 lk; K. Tamm).

Helifailidest digiteeriti 2011. aastal algfailidena u 412 tundi RKM, Mgn. II seeria materjali (T. Konsand) ning arhiveeriti kõvaketastel ja Blu-ray ketastel (J. Tamm). Selle tulemusena on algfailidena järjestikku digiteeritud lindid 1-3766. Järjestikku on palakaupa digitaalselt korraldatud ja kasutatavad RKM, Mgn. II seeria lindid 1-2500 (summaarne kestus umbes 521 tundi). Lisaks magnetofonilintide kogule digiteeriti linte endise Eesti Keele Instituudi helikogu seeria KKI, RLH lintidest algfailidena (T. Konsand) ja arhiveeriti (J. Tamm). 
Videokogust digiteeriti 16 VHS-kassetti (kokku 48 tundi materjali), ning 16 DV-kassetti, neist valmistati töö- ja tagatiskoopiad CD- ja DVD-kandjatel.

\section{Andmebaasid ja digiteerimine}

\section{Infosüsteemid}

Koostöös teiste kirjandusmuuseumi osakondadega jätkati tööd ühise failihoidla ja arhiiviinfosüsteemiga Kivike. Riigi Infosüsteemide Ameti menetlusel rahastatava europrojekti "Eesti trükise Punase Raamatu ja eesti kultuuri käsikirjaliste alliktekstide säilivuse ja kättesaadavuse tagamine" juhtrühmas olid M. Sarv (ühtlasi projekti tarkvara töörühma juht) ja R. Järv. Infosüsteemi Kivike väljatöötamises, aruteludes ning foto- ja videokirjeldusi puudutavates katsetustes osalesid M. Sarv, A. Tuisk, K. Tamm. Ühiselt osaleti 8.-10. juulil mõttetalgutel projekti juhi Kadri Tüüri juures Muhus (R. Järv, M. Sarv, J. Tamm, K. Tamm).

Kui senini on rahvaluulearhiivi kogud olnud kasutatavad peamiselt arhiivis kohapeal ja seega võrdlemisi piiratud kasutajaskonnale, siis Kivike võimaldab need kättesaadavaks teha ka laiemale üldsusele.

Esialgu oli kavas liidestada Kivikesega arhiivi andmekogude haldamiseks loodud infosüsteem Mari. Töö käigus ilmnes, et selle asemel on otstarbekas integreerida failihoidlaga ka arhiivi infosüsteem. Nõnda otsustatigi Kivike rajada nii, et ta täidaks nii failihoidla kui arhiivi infosüsteemi funktsioone. 2011. aastal toimusidki Kivikese arendus- ja programmeerimistööd paralleelselt andmete katselise sisestusega.

Baasi Mari tunnustesüsteem sobitati Kivikese põhimõtetega, seejärel viidi kokku konkreetsed tunnused ning kanti uude süsteemi üle varem Maris sisestatud andmed. Katselise andmesisestuse ja testimise tulemusena tehti tarkvaraarendajatele andmete sisestamise ja otsingutega seotud parandusettepanekuid.

Testperioodil sisestati eri projektide raames võimalikult erinevat liiki andmeid. Suurim sisestatud andmekogum oli tänu vastavale 
kultuuriprogrammi projektile Mulgimaalt kogutud rahvaluuleteadete metaandmete sisestamine andmebaasi (projekti juht M. Sarv; täitjad M. Aigro, K. Kulasalu, T. Soopa, J. Hunt). Nii sai Mulgimaa kihelkondade rahvaluulematerjal esimeseks suuremaks kogumiks, mille vastavad leheküljed Hurda käsikirjakogus on failihoidlast leitavad sisuliste tunnuste põhjal. Lisaks käsikirjalise materjali kirjetele sisestati projekti raames ka helisalvestuste kirjeldusi. Nii käsikirjalise kui helimaterjali andmekirjete sisestamine võimaldas testida kirjandusmuuseumi failihoidla töökindlust ja -mugavust. Kuna töö käigus oli võimalik teha parandusettepanekuid, osutus selle ajastus ka failihoidla programmeerimistööde seisukohalt väga kasulikuks. Kokku sisestati nimetatud projekti raames mulgi materjali 7427 käsikirjapala (Hurda käsikirjakogu) ja 959 helipala (ERA helikogud) andmed.

Jätkus töö regilaulude andmebaasi täiendamisega (projekti juht J. Oras, täitjad I. Annom, A. Kupits, Madli Oras, M. Sarv). Aasta jooksul valmistati baasi jaoks ette pool Eiseni kogu regilauludest, kollatsioneeriti ja redigeeriti vahemik E 15601-55679, kokku 5750 pala, tehti xml-failid, andmebaasi laaditi üles 8589 pala.

\section{Koostöö teiste asutuste, organisatsioonide ja välisriikidega}

Rahvusvaheline koostöö. Jätkus rahvusvaheline koostöö Soome Kirjanduse Seltsi rahvaluule arhiiviga nii kogumisvõistluse ühispublikatsiooni asjus kui seoses kummagi arhiivi rahvalaulude andmebaasidel põhineva ühisprojekti kavandamisega. Väliskoostöö jätkus ajakirja Journal of Ethnology and Folkloristics artiklite eelretsenseerimisel.

ERA teadlased kuuluvad mitmesugustesse rahvusvahelistesse erialaorganisatsioonidesse ja võrgustikesse: A. Korb, A. Lintrop ja A. Tupits rahvusvahelisse etnoloogia ja folkloristika ühendusse SIEF; R. Järv, A. Korb ja A. Lintrop rahvusvahelisse rahvajutu-uurimise ühingusse ISFNR. A. Korb osales teadusvõrgustikus 
BaltHerNet ida-suuna koordinaatorina, A. Lintrop Soome-Ugri Kongressi Rahvusvaheline Komitee (ICFUC) tegevuses. A. Tupits osales meditsiiniantropoloogia-alase ühenduse Netzwerk Gesundheit und Kultur in der Volkskundlicher Forschung (Saksamaa, Austria, Šveits) töös.

Eesti-siseselt jätkus tõhus koostöö Tartu Ülikooliga. Trükist tulid kirjandusmuuseumi, Tartu Ülikooli ja Eesti Rahva Muuseumi ühisajakirja Journal of Ethnology and Folkloristics numbrid 4/1 ja 4/2 ning 2011. aasta number 5/1. Ülikooli sissejuhatava rahvaluulekursuse raames jätkasid tudengid lühiajalise praktikaga ERAs, 69 tudengi töölõikudeks olid ennekõike fotonimestike ning ERA käsiraamatukogu kirjete sisestamine (juhendasid K. Tamm ja M. Aigro). Folkloristika magistriõppe arhiivipraktika sooritasid doktorant Toomas Pajula ning magistrandid Lona Päll ja Jaan Sudak; mitmete arhiivile oluliste töölõikude juures juhendasid M. Hiiemäe, R. Järv, J. Oras, K. Tamm, A. Tuisk, A. Tupits.

TÜ ja ERA koostöös esines 28. juunil kirjandusmuuseumi saalis TÜ külalisdoktorant Sadananda Singh Indiast, esitades kahe ja poole tunni jooksul katkendeid india eeposest "Mahābhārata" ning neid kommenteerides. Üritus talletati videosse (A. Lintrop ja J. Simm), salvestati helis (R. Järv) ning sellest tehti hulk fotosid (Alar Madisson).

Alates 2011. aastast on Tartu Ülikooli eesti ja võrdleva rahvaluule osakonna ning Eesti Kirjandusmuuseumi Eesti Rahvaluule Arhiivi muinasjuttude ühisprojekti edasiseks juhtasutuseks Eesti Kirjandusmuuseum. Sisuline töö tüpoloogia korrastamisel ja imemuinasjuttude antoloogia teise köite ettevalmistamisel (R. Järv, M. Kaasik, K. Toomeos-Orglaan) jätkus endisel moel, tööd ettevalmistamisel toetab Kultuuriteooria Tippkeskus.

R. Järv osales TÜ rahvaluule osakonna korraldatava üleriigilise rahvaluuleolümpiaadi žürii töös.

Koostööd tehti MTÜga Saaremaailm seoses koostööväljaande "Söit, söit, söit Sörve poole" rahvajutuosa ettevalmistamisega. MTÜ toetuse kaudu programmist "Saarte pärimuslik kultuurikeskkond 2011-2014” tasustati sisestaja tööd ning käsikirjaliste muistendite 
sisestamist (K. Kulasalu), muinasjutuprojekti poolt sisestati Saaremaa loomamuinasjutte (M. Meier).

Jätkus töö kohapärimuse andmebaasi ühendamiseks muinsuskaitseameti infosüsteemiga (M. Sarv ja kogu kohapärimuse töörühm) ning koostöö Eesti Keele Instituudiga seoses ERA kohapärimusteadete valimisega Eesti kohanimeraamatusse (projekti juht Peeter Päll). Aasta algul lõpetati 2010. aastal alustatud kohanimelugusid sisaldava materjali väljaotsimine Eesti kohanimeraamatu jaoks ning sisestamine ERA kohapärimuse andmebaasi (K. Kulasalu, V. Valper, P. Vahtmäe).

12. 05. 2011 sõlmiti SA Fennougria ja Eesti Kirjandusmuuseumi vahel leping projekti Nordplus raames koostatava soome-ugri veebientsüklopeedia rahvamuusika audiovisuaalsete näidete osa ning saatetekstide loomiseks. ERA ning etnomusikoloogia osakonna töötajate (R. Järv, H. Kõmmus, A. Lintrop, J. Oras, M. Sarv, T. Särg) aruteludel valiti välja autorid, kellelt märksõnaartiklid tellida. Aasta jooksul valmisid artiklid liivi ja mari rahvamuusika kohta (vastavalt Kristi Salvelt ja Lyudmila Yamursinalt), nende ja teiste autorite valitud eri rahvaste helinäiteid digiteeris T. Konsand.

Koostöö mitmes valdkonnas toimus maja kõigi osakondadega. Tehti eeltöid EKLA toimetusel ilmunud "Kalevipoja” tekstikriitilise juubeliväljaande ettevalmistamisel (T. Otsus).

ERA materjale avaldasid oma väljaannetes kirjastused Grenader, Pegasus, Tammerraamat, Ajakirjade kirjastus, Avita.

ERA teadustöötajad A. Kalkun ja J. Oras osalesid grandiprojektis "Teadmiste produktsioon rahvusteadusliku uuringu kontekstis” (7795, projekti juht K. Kuutma, TÜ), A. Tuisk grandiprojektis "Vägivaldne ja vabatahtlik deterritorialisatsioon eesti diasporaakogukondade näitel” (7335, projekti juht A. Jürgenson, TLÜ AI). A. Korb osales Tallinna Ülikooli taotletava grandi "Etniline ja rahvuslik eesti diasporaakogukondades” (grandihoidja Aivar Jürgenson) koostamisel.

Rahvaluulearhiivi töötajad jätkasid osalemist mitmetes otsustuskogudes: J. Oras kuulus Kultuuriministeeriumi vaimse kultuuripärandi nõukogusse, Eesti Rahvusliku Folkloorinõukogu pärimuskultuuri spetsialisti kutse andmise komisjoni ning oli Viljandi 
Kultuuriakadeemia ja Eesti Muusika- ja Teatriakadeemia ühise pärimusmuusika magistriõppekava väljatöötamise töörühma liige. M. Hiiemäe jätkas tegevust rahvapärase nimetuletuse eksperdina eesti linnunimetuste komisjonis ning osales ajalooliste looduslike pühapaikade ekspertnõukogu töös. M. Sarv osales Eesti Rahvusraamatukogu juurde loodud Eesti veebiressursside arhiivi veebiarhiveerimise ekspertide töörühmas.

A. Tuisk jätkas õpinguid folkloristika doktorantuuris (TÜ), J. Hunt jätkas doktoriõpinguid kultuuriuuringute alal (TLÜ). M. Meier jätkas magistriõpinguid Tartu Ülikoolis folkloristika erialal, J. Simm magistriõpinguid Norras, Tromsö Ülikoolis visuaalse antropoloogia erialal. A. Kalkun lõpetas õpingud TÜ folkloristika doktorantuuris.

Arhiivi töötajad osalesid mitmetel erialastel koolitustel - "Digitaalne säilitamine" TÜ raamatukogus (K. Tamm) ja "Andmekaitse muuseumitöös" (R. Järv) ning Rahvusarhiivi teabepäeval "Masinaga minevikku" (J. Hunt).

Osaleti eesti muuseumide festivalil Narvas 26.-27. septembril (M. Aigro, A. Kupits, R. Järv, A. Tuisk), R. Järv esines kirjandusmuuseumi esindajana ka festivali II päeva paneeldiskussioonis muuseumides tehtava teadustöö teemadel.

\section{Õppetöö, juhendamine, oponeeringud}

R. Järv pidas TÜ juures kevadsemestril loengukursuse "Eesti rahvajutt".

A. Kalkun pidas EELK Usuteaduste Instituudi juures magistriõppe lühikursuse "Pärimuskultuuri ja ristiusu seosed".

J. Oras oli Eesti Muusika- ja Teatriakadeemia pärimusmuusika laulueriala tudengite erialaõpetaja, viies aasta jooksul läbi nii individuaalõpet kui ansamblitunde. Sügissemestril pidas J. Oras samas ka loengukursuse "Sissejuhatus eesti rahvamuusikasse". TÜ Viljandi Kultuuriakadeemias pidas J. Oras kevadsemestril pärimusmuusika eriala loengukursused "Regilaulu keel ja poee- 
tika" ja "Regilaulu muusikaline keel" ning viis läbi tudengite arhiivipraktika.

J. Simm pidas Eesti Kunstiakadeemia juures loengutsükli visuaalse antropoloogia teooriast rahvakunsti ja kultuurantropoloogia magistrantidele.

A. Tuisk koostas koos Tiiu Jaagoga (TÜ) e-minikursuse "Rahvaluule - kuidas, kust ja millest".

R. Järv juhendas Moon Meieri magistritööd "Tänapäevase jutuvestmise mõtestamisvõimalusi: András Bereczi ja Terje Lillmaa seisukohad", K. Toomeos-Orglaane doktoritööd "Kultuuritüpoloogiate rakendused muinasjutužanris" ning K. Kikase doktoritööd "Rahvaluulekogumine kui kohtumine avalikus kirjaruumis: Jakob Hurt, Matthias Johann Eisen ja nende rahvaluulekorrespondendid privaatse ja avaliku kommunikatsiooni piiril" (kõik Tartu Ülikoolis).

M. Hiiemäe oponeeris Piret Voolaiu doktoriväitekirja "Eesti mõistatused kui pärimusliik muutuvas kultuurikontekstis" (Tartu Ülikool).

A. Korb oponeeris Jane Kalajärve magistritööd "Kultuuriidentiteet ja koduinterjöör Kanada eestlaste näitel" (Eesti Kunstiakadeemia).

J. Oras oponeeris Liisi Laanemetsa magistritööd "Iseendaks olemisest eneselavastamiseni Tallinna setode leelokoori Sõsarõ näitel" (Tallinna Ülikooli Eesti Humanitaarinstituut).

A. Tuisk oponeeris Eleene Sammleri bakalaureusetööd "Eesti laste kirjad jõuluvanale: soovid traditsiooni keskmes” (Tartu Ülikool).

\section{Tee oma elust luule Tartus!}

Rahvaluulearhiivi töös on juba alates selle alguspäevadest tavaks põimida omavahel teadus- ja arhiivitööd. Et olla rohkem nähtav ka meie olulisima koostööpartneri, Eesti rahva jaoks, kelle huvides 
ja nimel me töötame, püüdsime 2011. aastal tõsise teadustöö, ajamahuka arhiivitöö ja raskete olude kiuste täiendavalt aega ja ettevõtlikkust leida avalikkusele suunatud populariseerivate tegevuste jaoks. Just ERA eestvõttel osales Eesti Kirjandusmuuseum juba teist korda rahvusvahelise muuseumiöö programmis ning esmakordselt ka Teadlaste Öö festivali üritustel. Rahvusvahelisel muuseumiööl 14. mail (programmi juht M. Aigro) avati M.-A. Remmeli õlimaalide näitus ERA trepigaleriis, vaadata oli Villem Reimani 150. sünniaastapäevale pühendatud näitus "Aardeleide arhiivraamatukogust” EKLA materjalide põhjal, vaadati filmi vepsa rahvustoidu tegemisest, toimus aardeotsimismäng, mille käigus tehti tutvust aardejuttudega, ning esitleti kirjastuses "Ilmamaa" ilmunud Uku Masingu artiklikogumikku "Aarded tellistes". 23.09. toimunud Teadlaste Ööl (projekti üldkoordinaator A. Tuisk) kuulati loenguid inglitest reklaamides (Reet Hiiemäe), vanadest trükistest (Kadri Tüür) ning põnevat sissevaadet arhiiviloosse kirjanik Karl Ast Rumori diplomaatilise passi näitel (Janika Kronberg). Trepigaleriis avati A. Kuperjanovi ja M. Kõiva fotonäitus "Surva”. Maja külastanud noored teadustööhuvilised tegid tutvust muinasjuttudega ning lahendasid viktoriiniülesandeid.

Tartu 2011. aasta suveniirikonkursi poolesajast tööst pälvis žürii otsusega teise koha Tartu-teemaliste kõnekäändude ja vanasõnadega märkmepaberikomplekt "Tee oma elust luule Tartus", idee autor ja projekti juht oli M. Aigro, kujunduse tegi S. Roots, abijõududeks olid I. Annom, R. Järv, A. Kalkun ja P. Vahtmäe. Märkmepabereid tellis Tartu linn ning suvel trükiti väikeses tiraažis ka kirjandusmuuseumi suveniireksemplarid.

Aasta algul ilmus rahvaluulearhiivi algatusel koostatud Eesti Kirjandusmuuseumi "Kalender 2011/2012" (koostajad Vilve Asmer, R. Järv, Merike Kiipus, Kadri Tüür), mis tutvustas käimasolevat kolme arhiivi suurdigiteerimisprojekti ning infosüsteemi Kivike loomist. Kaheaastakalendris anti ülevaade selle mastaapse ning Eesti mäluasutuste seas ainulaadse projekti käigus digiteeritavast ainesest, igast arhiivist valiti tutvustuseks kaheksa ilmestavat kalendrilehte. 
Digiteerimisprojekti reklaamiks, kuid teisalt arhiivi olelusprobleemide üheks väljenduseks oli ka 1. aprilli eelõhtul meediakanalitele saadetud pressiteade "Heategevuslikul oksjonil müüakse Jakob Hurda rahvaluulekogu 10 köidet" - rühma spontaanselt tekkinud eneseväljendus folkloorses vormis. Loodame väga, et kujuteldava oksjoni põhjenduseks välja käidud mõte heategevusest ehk juba digiteeritud käsikirjade müümisest arhiivi ülalpidamiskulude katteks ei kerkiks kunagi meie mäluasutuse finantseerijate pähe. Ühtlasi loodame, et praeguse täielikult projektipõhise rahastussüsteemi asemele tuleks vähemalt osaliselt püsirahastus meie väärtuslike kultuurikogude hoidmiseks, täiendamiseks ja kättesaadavaks tegemiseks. 


\section{Etnomusikoloogia osakond}

\section{Triinu Ojamaa}

\section{Osakonna koosseis ja rahastusallikad}

2011. aastal koosnes etnomusikoloogia osakonna uurimisgrupp kaheksast liikmest: vanemteadur-osakonnajuhataja Triinu Ojamaa, vanemteadurid Taive Särg ja Ingrid Rüütel ning teadurid Kanni Labi, Aune Valk, Kristel Karu-Kletter, Guldžahon Jussufi ja Helen Kõmmus. Assistendina töötasid Julia Sulina ja Mari Bleive. Julia Sulina õpib Eesti Maainstituudi ja Helen Kõmmus Tampere Ülikooli doktoriõppes.

Teadustöö peamine rahastusallikas oli SF0030068s08 "Muusika perspektiivid Eesti avatud identiteedi väljakujundamisel" (20082012), teemajuht T. Ojamaa. Projekti raames tegeldi järgmiste uurimisküsimustega: Millisel grupil (eesti- ja diasporaaeestlased, eesti venekeelne diasporaa) on kõrgeim potentsiaal Eesti avatud identiteedi kujunemiseks? Kas kontakt eesti muusikaga ja muusikaline ühistegevus mõjutavad venekeelse diasporaa ja Eesti läänediasporaa identiteeti? Milline on muusika osa Eesti regionaalsete identiteetide püsimisel?

Teadustegevust toetasid I. Rüütli juhitud projekt "Eesti regiviiside andmebaasi redigeerimine ja täiendamine" (Riiklik programm "Eesti keel ja kultuurimälu"). Projekti täitjatena osalesid Edna Tuvi ja Koit Haugas, kes tegelesid varem sisestatud materjali põhjaliku kontrolli ja ilmnenud vigade parandamisega. Samast allikast rahastati ka I. Rüütli projekti "Lääne-Eesti pärimustantsude koreograafiline tekst ja esitusviis". Projekti eesmärgiks oli 
eesti pärimustantsude audiovisuaalsete salvestuste ja sõnaliste kirjelduste publitseerimine ning tantsu kohalike eripärade ja nende muutumise uurimine. Projekti täitjad olid Angela Arraste, Sille Kapper ja Krista Sildoja.

\section{Teadustöö ja publikatsioonid}

Sihtfinantseeritava teema raames oli põhirõhk küsimustiku "Muusika ja identiteet" (www.kirmus.ee) kaudu saadud info esialgsel analüüsil. Kokku laekus 2011. aasta lõpuks elektrooniliselt ja paberkandjal 1878 täidetud ankeeti. Esialgseid uurimistulemusi sisaldab A. Valgu, K. Karu-Kletteri ja M. Drozdova artikkel "Estonian Open Identity: Reality and Ideals" (TRAMES, Journal of Humanities and Social Sciences No 1, 2011). Lisaks ilmusid T. Ojamaa monograafia "60 aastat eesti koorilaulu multikultuurses Torontos. 60 Years of Estonian Choral Singind in Multicultural Toronto" (esitlus toimus 10. aprillil Torontos).

Lisaks ilmusid 2011. aastal järgmised artiklid:

K. Karu-Kletter, "Iisraeli venekeelne vähemus", Akadeemia, 1, 83-119.

H. Kõmmus, "Ethnomusicological field work in internet. Case of Fenno-ugric folklore festivals research", Csúcs, S., Falk, N., Tóth, V. \& Zaicz, G. (toim.) Dissertationes sectionum et symposiorum ad ethnologiam, folkloristicam et mythologiam. Congressus XI. Internationalis Fenno-Ugristarum. Reguly Társaság, Piliscsaba, 100-119.

K. Labi, "Isamaalaulud ja okupatsioonirežiim - nostalgia, utoopia ja reaalsus", Methis. Studia humaniora Estonica, 7, 109-121.

K. Labi, "Krabisev ja kõlisev eestikeelses aegruumis", Keel ja Kirjandus, 5, 343-359.

T. Ojamaa, "Searching for Structural Boundaries in Forest Nenets Songs: A cross-cultural Case Study", Lotman, M. \& Lotman, 
M.-K. (toim.), Frontiers in Comparative prosody. Bern, Berlin, Bruxelles, Frankfurt am Main, New York, Oxford, Wien: Peter Lang, 227-250.

T. Ojamaa ja J. Ross, "The perceived structure of Forest Nenets songs: A cross-cultural case study", Psychomusicology: Music, Mind \& Brain, Vol. 21, No. 1 \& No. 2, 159-175.

T. Särg ja A. Johanson, "Pärimusmuusika mõiste ja kontseptsiooni kujunemine Eestis”, Mäetagused, 49, 115-138.

\section{Populariseerivad artiklid}

K. Labi, "Words as Events or Events as Words". Folklore, Electronic Journal of Folklore, 48, 211-214.

A.Valk ja T. Ojamaa, "Identiteedist ja selle muutumisest väliseesti ühiskonnas”, Rahvuslik Kontakt, 4. Stockholm: Rootsi Eestlaste Liit, 21-27.

I. Rüütlil ilmus kokku 6 kirjutist, mis käsitlevad populaarses vormis eesti kultuurielu eri aspekte:

"IV laulupeoke Mustamäe lasteaedades. IV pesennõi prazdnik v detsadah Mustamjae”, Mustamäe. Mustamäe linnaosa ajaleht. Nr 7 (204), 2011, 4.

"Rusko-turskata voina (1877-1878) v estonskata pesenna tradicia", Evropa. Dvumesecno izdanie za kultura i socialna poliitika broi 5, 2011, 44-46.

"Rahvamuusika märgilisest tähendusest", AegKiri 4. Enne ja nüüd. Muuseumi ringreisid 1008-1009-1010. Tallinn 2011, 2007-2013.

"Uusi andmeid eesti torupillist ja Rootsi-Eeesti kultuurisuhetest XVIII sajandi alguses”, AegKiri 4. Enne ja nüüd. Muuseumi ringreisid 1008-1009-1010. Tallinn 2011, 2014.

"Kihnu tantsude ajaloost (tantsimise tavad ja olukorrad)", Kyne nr 10, tali 2011, 3-6. 
Mitu teadusartiklit ootavad ilmumist väljaannetes, mis plaani kohaselt oleksid pidanud ilmuma 2011. aastal, nt T. Särje ja A. Valgu ankeetküsitlusel ja intervjuudel põhinev uurimus "Leelo is the way of life. Construction of ethnic identity and its relation to traditional music in Setomaa, South Estonia" ajakirjas Folklore, mis sihtfinantseeritava teema seisukohalt on väga oluline artikkel.

ETIS-e andmetel ootab 2011. aasta numbriga ilmumist veel 4 publikatsiooni, mille tegelik avaldamisaeg pole 2012. aasta II kvartaliks selgunud: I. Rüütli kandidaadiväitekirjal põhinev monograafia "Eesti uuema rahvalaulu kujunemine", mille seadsid trükivalmis K. Labi ja T. Otsus, kuid mille trükikulud ületavad võimaluste piire, samuti tema "Soorollidest ja naistest Kihnu kultuuris" (Sator). T. Särje "Ingrid Rüütel korrastamas eesti regiviiside tihnikut: emantsipatsioon eestipäraselt” Keeles ja Kirjanduses on samuti veel ilmumata nagu ka mahukas artikkel "Eesti regilauluviisid ja rahvamuusika 20. sajandi alguse haritlaste vaates" (Eesti Rahvaluule Arhiivi toimetised). Kokkuvõttes ei olnud 2011. aasta publikatsioonide osas kuigi tulemuslik.

\section{Konverentsid, seminarid, ettekanded}

\section{Teaduskonverentsid ja koostöö teiste teadusinstitutsioonidega}

T. Ojamaa osales 14.-16. aprillil 2011 organisatsiooni Association for the Study of Nationalities 16. aastakonverentsil NY Columbia ülikoolis. Ettekanne "Music as an ethnic and regional demarcator" kuulus paneeli "Integration in Estonian Society: Challenges and Perspectives”. Paneeli juhatas Raivo Vetik ning see oli osa koostööprojektist "Sünergia ja interdistsiplinaarsuse arendamine Eesti integratsiooniuuringutes" (2011-2014). Projekt on sõlmitud EKM etnomusikoloogia osakonna ja Tallinna Ülikooli riigiteaduste instituudi vahel. Projekti eesmärk on välja arendada uurimisvõrgustik nende Tallinna Ülikooli ja Eesti Kirjandusmuuseumi teadustöötajate vahel, kes tegelevad integratsiooni- ja identiteediuuringute eri aspektidega. 
H. Kõmmus osales ettekandega kolmel rahvusvahelisel teadusüritusel:

"Kaustinen Folk Music festival and Viljandi Folk Music Festival - questions about festival research methodology", konverentsil "Traditional Music Research in Baltic region and British Islands" Corki Ülikoolis 19.-23.septembril;

"Folk music festivals' influence to terminology of traditional music research" Soome Etnomusikoloogia Seltsi seminaril Helsingi ülikoolis 21.-22. novembril;

"Methodology: ethnomusicological methods of collecting, systematizing and analyzing the folk music and folk music fusion festivals research material in Finland and Estonia"

Tampere Ülikooli etnomusikoloogia osakonna doktoriseminaril 4. detsembril.

\section{Populaarteaduslikud ettekanded}

A. Valk ja T. Ojamaa esinesid ühisettekandega "Identiteedist ja selle muutumisest väliseesti kogukondades" Rahvuskaaslaste II konverentsil Tallinnas 29. septembril. Ettekande põhjal valmis 2 populaarteaduslikku artiklit, mis ilmusid ajakirjades Rahvusik Kontakt (2011) ja Lennuk (2012).

I. Rüütli populaarteaduslikud ettekanded ja loengud 2011 aastal:

"Kihnu tantsude tavad ja esitamisolukorrad" Eesti Kirjandusmuuseumi folkloristide talvekonverentsil 4. veebruaril;

“Keelemängud ja kõlailu lauludes ja luules” Eesti Segakooride Liidu Emakeelepäeva kontserdil Haapsalu Kultuurikeskuses 14. märtsil;

"Pärimuskultuuri mõistest” Emakeele päeva üritusel Pikanurme koolis 17. märtsil;

Loeng "Kihnu pärimustantsude ajaloost" Eesti Rahvusliku Folkloorinõukogu Koolituskeskus Tallinnas Rahvakultuuri Hariduskeskuses 31. märtsil; 
Ettekanne "Muutudes rahvana kestma jääda" eestikeelse kooli 325. aastapäevale pühendatud konverentsil "Haridus on valgus. Eesti kool vaatab tulevikku" Teadus- ja Haridusministeeriumis 8. aprillil;

Loeng "Kihnu tantsude ajaloost" seminaril Kihnu rahvamajas "Kihnu Tansu Päe" 13. augustil;

Loeng "Säilyvä ja muuttuva Kihnun kulttuuri” Vuojoen Kartano kultuurikeskuses 30. augustil;

Loeng "Kultuuri rollist eesti rahvuse kujunemises ja kestmises" TÜ Pärnu kolledži Väärikate Ülikoolis 28. septembril;

Loeng "Kihnu traditsioonid ja uuem rahvalaul” pärimusmuusika õppelaagris Kaika koolis 17. novembril.

\section{Akadeemilised välitööd}

Paralleelselt ankeetküsitluse "Muusika ja identiteet" läbiviimisega toimus intervjuude kogumine nii Eestis (J. Sulina), Ameerika Ühendriikides (K. Karu-Kletter) kui Austraalias (T. Ojamaa). Kokku on salvestatud 32 intervjuud eesti, vene ja inglise keeles, mida osaliselt on kasutatud ülal loetletud uurimustes.

T. Särg käis 2011. aasta märtsis uurimas pärimuskultuuri õpetamise olukorda Setomaa koolides.

T. Ojamaa töötas jaanuaris 2011 Sydney Eesti Maja arhiivis, valides materjali kavandatavale väljaandele austraaliaeestlaste muusikaelust.

T. Ojamaa ja J. Kronberg toimetasid Stockholmist Tartusse osa Harri Kiisa isiklikust arhiivist. Materjal leiab kasutamist monograafias "Harri Kiisk - eesti kultuuri vahendaja Rootsis".

Kokkuvõtteks tuleb tõdeda, et 2011. aasta tulemustest on nii mõndagi õppida. Muutunud teaduskorralduse tingimustes konkurentsis püsimine eeldab ulatuslike süvauurimuste asemel pigem kitsamale probleemile keskendunud lühiuurimuste kirjutamist, mis võiksid huvi pakkuda regulaarselt ilmuvatele teadusajakirjadele. 


\section{Folkloristika osakond}

\section{Mare Kõiva}

Folkloristika osakonna kolmes struktuuriüksuses (usundi- ja jutu-uurimise, lühivormide ja meediarühmas) töötas 2011. aastal 17 teadustöötajat: juhataja Mare Kõiva, vanemteadurid Eda Kalmre, Arvo Krikmann, Asta Õim, Katre Õim (osakoormus), Tõnno Jonuks, Liisi Laineste, teadurid Anneli Baran, Mare Kalda, Andres Kuperjanov, Nikolay Kuznetsov (osakoormus), Reet Hiiemäe (osakoormus), Piret Paal (osakoormus), Renata Sõukand (osa aastast vanemapuhkusel), Piret Voolaid, Katre Kikas (osakoormus). Teemaga olid seotud veel toimetajad Maris Kuperjanov, Asta Niinemets, Rein Saukas (pensioneerus oktoobrikuus), Liisa Vesik, Mall Leman, programmeerija ja võrguadministraator Saamuel Vesik, assistendid ja projektitäitjad Salle Kajak, Helen Hanni (II poolaastal osakoormus), Eva-Kait Kärblane, Raivo Kalle (osa aastast vanemapuhkusel), Kaisa Sammelselg (osakoormus) ja järeldoktorant Lina Gergova.

Aasta jooksul abistasid meid Eesti Folkloori Instituut, Enn Ernits, Tiiu Jaago, Indrek Kiissel, Tuul Sepp, Ülo Siimets, Kärt Summatavet, Tartu Tähetorni astronoomiaring, Maarja ja Viire Villandi, Vallo Tikk; Wiki-meeskond eesotsas Raul Veedega ja Kaija Rumm. Tekste aitasid digiteerida Tiiu Jaago eesti rahvaluule üldkursuse kuulajad Tartu Ülikoolist. Külalisteadlastest olid osakonnale abiks Sloveenia TA Etnoloogia Instituudi teadur ja toidukultuuri uurija Maja Godina Golija (10.-17. aprillini), Mihály Hoppál (Etnoloogia Instituut, Budapest, Ungari), järeldoktorandid Lina Gergova ja Liisa Granbom-Herranen. 


\section{Teadustöö ja publikatsioonid}

Sihtfinantseeritava teadusteema "Folkloori narratiivsed aspektid. Võim, isiksus ja globaliseerumine" raames tegeleti eesti ja soome-ugri rahvaste keele, kujundkõne, lühivormide, juttude ja rahvausundi uurimisega; analüüsiti multimeedia probleeme, jätkati interneti-uuringute ja mitmete rakendusprojektidega. Teema peamine uurimissuund keskendus narratiivsuse eri aspektidele, liikidele ja segmentidele üleilmastumise ja sotsiaalkultuuriliste mõjurite kontekstis. Avaldati 11 raamatut ja teesikogumikku, 7 numbrit eelretsenseeritavaid ajakirju ja 5 e-raamatut/andmekogu ning 2 populaarset tekstivalimikku. Lisaks toetas osakonna tööd 2011. aastal teadusaparatuuri ja -seadmete kaasajastamise projekt 3.20301.10-0247 "Väikesemahulise teaduse infrastruktuuri kaasajastamine" teadusteema SF0030181s08 raames.

Eesti Teadusfondi grante oli kolm: M. Kõiva "Kultuuriprotsessid Interneti kogukondades. Narratiivid, väärtushinnangud ja kohaloome"; L. Laineste "Kultuuriprotsessid muutuvas ühiskonnas: Traditsioon ja loovus postsotsialistlikus huumoris"; T. Jonuks "Religiooni materiaalsus".

Riiklikus sihtprogrammis "Eesti keel ja rahvuslik mälu” osaleti projektidega "Eesti folkloori fundamentaalväljaanded. Muistendid ja loitsud” (M. Kõiva), "Eesti keele, kultuuri ja folkloori kasutusalade laiendamine ja tutvustamine elektroonilisel infokandjal" (A. Kuperjanov), "Eesti kõnekäändude ja fraseologismide andmebaas ja fraseologismide allikpublikatsioon "Monumenta Estoniae Antiquae" sarjas" (A. Baran), "Historistlik eesti rahvameditsiini botaaniline andmebaas (HERBA) ja satelliitandmebaasid” (R. Sõukand), "Eesti ja Ida-Euroopa huumor ja mõistatused: globaliseerumine, lokaliseerumine ja žanriuuendused" (L. Laineste), "Eelretsenseeritava humanitaarajakirja Folklore: Electronic Journal of Folklore publitseerimine" (P. Voolaid).

Riikliku programmi "Eesti keele keeletehnoloogiline tugi" all oli täitmisel projekt "Eesti fraseologismide elektroonilise alussõnastiku loomine” (K. Õim). Kahe projektiga (A. Baran, E. Kalmre) 
osaleti riiklikus saarte pärimuskultuuri programmis. Lisatoetust saadi Eesti Kultuurkapitalilt ajakirja Mäetagused väljaandmiseks ja konverentside läbiviimiseks. Osakonna hallatav server Haldjas teenindab rahvusvahelisi postiloendeid (Rahvusvahelise Tänapäeva Muistendite Seltsi uurijate list ja Medica - rahvusvaheline meditsiiniuurijate list). Serveris on kättesaadav ka Rahvusvahelise Tänapäeva Muistendite Seltsi uudisleht FOAFTale News, mida kaastoimetas E. Kalmre.

\section{Rahvajutud ja -usund}

Käsitleti nii vanemat kui uuemat traditsiooni, sõltuvalt temaatilistest raskuspunktidest. Üks keskseid teemasid oli jätkuvalt muistendite kasutamine tänapäevases ühiskonnas, intertekstuaalsed suhted, aga ka "Monumenta Estoniae antiquae" sarja muistendiväljaannetega seotud temaatika. Põnevaid avastusi pakkus juttude usundilise ja sotsiaalkultuurilise tausta avamine (nt meditsiini- ja aardenarratiivide näitel, aga ka seoses kombestikuga (M. Kalda, M. Kõiva, K. Kikas, E. Kalmre, A. Kuperjanov, L. Vesik). Hoogustus etnobotaaniline uurimistöö (R. Sõukand, R. Kalle).

Pingelise töö raames Eesti aardepärimusega lõpetas ja kaitses M. Kalda doktoriväitekirja "Rahvajutud peidetud varandustest: tegude saamine lugudeks" (274 lk), mis koosneb teoreetilisest ülevaatest ja neljast artiklist, milles on käsitletud jutte ja teateid peidetud varandustest eesti folklooris. Vaateviisi ja allikate poolest jätkab dissertatsioon arhiivipõhise rahvaluuleuurimise traditsioone. Aardetemaatikat puudutas ka M. Kalda uurimus "Tagasi Tammiku Rahaaugumäele. Kas kohanimes on lugu sees?". Eesti-Poola kultuuriuuringute ühisprojekti raames ("Meaning-making through treasure stories”) valmis ülevaade eesti aardepärimusest, jätkus aardejuttude koondamine peidetud varanduste teemalise "Monumenta" tarbeks. Uuendamisel oli artikkel Ida-Virumaa kohapärimuse ülevaatega "See on minu paik!" Ida-Virumaa kohamuistenditest" (toimetaja Ingrid Rüütel; esmailmumine 1992), toimetamisel oli P. Paali halltõve-teemaline "Monumenta". Folkloristika populariseerimise korras ilmus 15. jaanuari Päevalehes M. Kalda essee "Üks pealtnähtud rahavestlus - kuidas sünnib loits". 
E. Kalmre jätkas narratiivide uuema kihistusega, täiendades välislugeja jaoks oma 2007. aastal ilmunud monograafiat "Hirm ja võõraviha sõjajärgses Tartus”, mis valmis uue eessõna ja täiendustega. Töös olid järgmised teemad, millest valmisid ka artiklid: "Kuulujutud ja tänapäeva muistendid rahvusliku identiteedi loomise protsessis"/ "Rumours and contemporary legends as part of identity creation process" ning laiendamisel oli uurimus "The Tradition of Girls' Manuscript Love Stories in the Last Century and Today". Sõrve-projekti jaoks jätkus kogumisloo kirjutamine, valmisid uued käsitlused "Ühest Sõrvemaa naisest tema elu, keskkonna ja pärimuse kontekstis", "About the Folklore Process: On the Example of the Sõrve Peninsula". Tellimustööna valmis linnamuistendite kogumik “Tüdruk veiniplekiga kleidis. Tänapäeva hirmuja õudusjutte” (Tallinn, Ajakirjade Kirjastus).

M. Kõiva jätkas eeskätt usundiliste ja meedianarratiivide käsitlemisega. Üks suuremaid ainestiku koondamisi oli seotud Kolga-Jaani kihelkonna ravija Serva Elluga. Täiskorpuse najal vaadeldi selle silmapaistva 19. sajandi ja 20. sajandi alguse loitsija elukäiku ja sellest tõukuvaid, osalt iseseisvaid, kuid rahvauskumuslikku raami sobitatud narratiive. Käsitlemist leidsid ka meediumi mütologiseerimise protsessi erijooned võrrelduna temalt talletatud folklooriga, samuti tema kaudu levinud kirjalik pärimus.

Jätkus töö rituaalse aasta tähtpäevadega nende diakroonilise ja sünkroonilise arengu baasil. Peamiselt koguti ainestikku postsotsialistliku versus sotsialistliku kalendritavandi kohta, et täpsemalt fikseerida muutusi 20. sajandi kalendritavandis (M. Kõiva). Esmaülevaade kalendripühade transplantatsioonist, ennistamisest ja juurutamisest ning kalendriprotsesside dünaamikast valmis Eesti-Poola ühisprojekti jaoks. Koostöös A. Kuperjanoviga valmis käsitlus ühest omapärasemast üleminekuriitusest eesti koolielus, nn tutipäevast või viimasest koolikellast. Käsitluses tõsteti esile kombestikku mõjutavaid asjaolusid, pärimusliinide edasikandumist õpilaste vahendusel jm ("Back to the first class. Rituals connected with finishing school"). Ühe uuskalendrilise tähtpäeva muutumist ja kohanemist Eesti tavandis vaatles L. Vesik valentinipäeva näitel (“Валентин день”). 
Jätkus eepilise pärimuse (Tõllu-pärimus, Kalevipoeg) vaatlemine intertekstuaalsete suhete, kultuuriliste etteantuste ja identiteediloome osana, samuti paradigmasse uute narratiivivormide lisandumise vaatlemine (M. Kõiva "Kalevipoeg as the Basis of New Narrative Forms", M. Kõiva, A. Kuperjanov "Signs of Giants in the Islands"), samuti kuulsuste ja identiteediloome seoste vaatlemine president ja kirjanik Lennart Meri näitel (M. Kõiva "Lennu-Phenomenon"). Seegi käsitlus on varasemate sama isikuga seotud folkloorsete ja kultuuriliste protsesside jälgimise edasiarendus.

K. Kikas jätkas rahvusideoloogia väljendumisviiside, koguja H. A. Schultsi allikakäsitluse ja rahvusromantilise rahva/rahvuse/ eepose mõiste seoste, samuti sama korrespondendi ja tema kaasaegsete kirjameeste suhete vaatlemist. H. A. Schultzi eeposetõlgendusi käsitleb tema artikkel “"Dr. Kreutzwald Has Been Blamed..." A Village Tailor H. A. Schults Defending the Authenticity of Kreutzwald's Kalevipoeg". K. Kikasel valmis doktoritöö projekt "Rahvaluulekogumine kui kohtumine avalikus kirjaruumis: Jakob Hurt, Matthias Johann Eisen ja nende rahvaluulekorrespondendid privaatse ja avaliku kommunikatsiooni piiril" ja sellest tõukuv uurimus "Jakob Hurda ja Matthias Johann Eiseni vastuolu kajastumine rahvaluulekogujate kirjades". Ettevalmistustöid tehti uurimuseks "Books for common people and books for intellectuals: strategies for publishing folklore in 1890s Estonia" ja käsitluseks "In the footsteps of Kalevipoeg. (Re)locating legendary places in the Soviet Estonia", mis vaatleb 1950. aastate tudengiekspeditsioone Kalevipojaga seotud paikadesse.

R. Hiiemäe tegutses saksakeelset folkloristikat tutvustava eestikeelse kogumiku "Mis on Gilgamešil pistmist geeniuurimisega?" koostamise ja tõlkimisega. Valikusse kuulusid tuntud folkloristide, etnoloogide ja kultuuriuurijate kirjatööd: Ingrid Tomkowiaki "Mis on Gilgamešil pistmist geeniuurimisega?", Klaus Rothi "Te võite olla üllatunud minult seda kirja saades", Heiner Goldingeri "Prohvetlus kui elukutse: ühe etnoloogilise fenomeni avaldumine traditsioonilistest kultuuridest kuni kaasaegse ärimaailmani”, Brigitte Frizzoni "Shrek kui postmodernne muinasjutt", Klaus Grafi "Jutumotiivid varauusaegsetes kuritegude uurimisdokumentides", 
Gunther Hirschfelderi "Ekstreemsed ilmastikunähtused ja kliimamuutused kultuuriteooria vaatenurgast", Arne Kunzi "Tere tulemast arvutimängu "World of Warcraft" imelisse maailma". Valmis ka tõlge saksa keelde R. Hiiemäe kirjutatud eesti ainestiku paralleelidest L. Petzoldti "Deemonite ja vaimolendite leksikonile".

Lisaks valmisid R. Hiiemäel ettekanded ja kirjutised aktuaalsetel usundi- ja narratiiviteemadel: "Rollid ja rollikäitumine interneti esoteerikafoorumites" ja "Kommertsmaailma sõnumitoojad: ingli kuvandi stereotüübid tarbijareklaamides", samuti teesid "Moderne esoterische Spiritualität als Wettbewerb". Valmis antoloogia laadis raamat kaitsemaagiast, mille kirjastamiseks 2012. aastal sõlmiti kokkulepe kirjastusega Pegasus.

Meditsiiniuskumustele ja -narratiividele oli pühendatud konverents "Medica 8", mis võimaldas interdistsiplinaarset vaadet digiajastu eri suundumustele. Peeti 9 ettekannet, esinejaid oli Eestist, Saksamaalt, Ungarist, Bulgaariast ja Venemaalt.

Lähtudes pikemaaegsetest välitöödest ja küsitlustest jätkus eesti meediumidega seotud probleemistiku vaatlemine. Eeskätt käsitleti tänapäevaste eri põlvkondade ravijate maailmavaate aluseks olevaid tekste ja eeskujusid, nende osalemist meditsinikirjanduse loomises, samuti osalemist laiemas kultuuriloomes - uurimistulemused vormusid käsitlusteks "Медиум как резервуар знании" ја "Constructive alternativism and the Healers" (M. Kõiva). Jätkus ka meediumide kui uute rituaalipaikade loojate ja mitmete kultuuriliselt oluliste paikade sakraliseerijate vaatlus, teisalt oli tähelepanu all vanemate ja uuemate tähtpäevade taasjuurutamine meediumide ja konkreetsete huvirühmade poolt rituaalse aasta osisena. Viimase protsessi üheks oluliseks lähtealuseks peeti isiksuse vabu valikuid maailmavaate ja selle osiste kujundamisel ning kasutamisel (ettekanne "Making the ritual space and place", artikkel "Women's Holidays and Porridge Rites", M. Kõiva).

Edukas oli uurimistöö etnobotaanika alal. Valmisid etnobotaanilise teabe kogumistöö üldtendentside ja taimravis kasutatud taimeteadmuse muutuste vaatlused R. Sõukandi ja R. Kalle koostöös: "Change in medical plant use in Estonian ethnomedicine: a historical comparison between 1888 and 1994", "Etnobotaanika mõiste, 
materjali kogumise ajalugu ja kogumissoovitused", "Ajalooline ülevaade eestlaste looduslikest toidu- ja ravimtaimedest", "Collectors of Estonian Folk Botanical Knowledge", "Gustav Vilbaste kui etnobotaanilise ainese koguja, uurija ja publitseerija”, "Personal and shared: the reach of different herbal landscapes", "Eestikeelsete rahvapäraste taimenimede kategoriseerimine ja selle rakendatavus tänapäeval” ning "Tõlked ja valetõlked Eesti taimepärimuse mõjutajatena". Ühe uue teemana kerkis esile looduslike toidutaimede teema, millest valmis mitmeid uurimusi: "Looduslike taimeliikide söögiks tarvitamine Eestis", "Toidukultuuri kogumine ja vahendamine: individuaalsed ja institutsionaalsed vaatepunktid"/ "Recollecting and mediating food culture: individual and istitutional perspectives" (R. Kalle, R. Sõukand), "Wild plants in Estonian food culture: outline of research sources" (R. Kalle), "Personal and shared herbal landscapes" (R. Sõukand).

Loitsude alal uuriti kohta ja paika loitsudes ja neid saatvates rituaalides, suurenev korpus võimaldas täiendada koodivahetuse ja mitmekeelsuse uurimust loitsude näitel (eesti-vene, eesti-ladina, eesti-saksa keelekoodi vahetused) ning lähemalt jälgida loitsude otsese tõlkimise või ümberkirjutamisega seotud seiku ja muutusi (“Mitmekeelsed loitsud. Kas tõlked või koodivahetus?"). Jätkus taevakirjade, nõiaraamatute ja loitsukäsikirjadega seotud folkloori ja tegelike käsiraamatute ajaloolise leviku ja konsistentsi jälgimine. Ühe rahvaluulekogu näitel vaadeldi loitsukäsikirjade temaatilist sisaldust, intertekstuaalseid suhteid ja tekstidele iseloomulikke jooni, vormusid mitmed ettekanded ja ilmusid artiklid "Колдовские, магические и заговорные книги в эстонском фольклоре", "Letters from Heaven and Manuscript Incantation Collections", "Käsikirjalised nõiaraamatud" (M. Kõiva). Ilmus teaduslik antoloogia "Eesti loitsud". ISNFRi töörühm eesotsas komiteega asutas rahvusvahelise ajakirja Incantatio, mille peatoimetaja on M. Kõiva, tehniline toimetaja L. Vesik, valmis ajakirja esmanumber viie uurimusartikli ja ülevaateosaga ning ajakirja veebikeskkond.

Tähistaevaga seotud uskumusi käsitleti SEACi aastakonverentsil Portugalis (M. Kõiva, A. Kuperjanov), valmisid käsitlused kuust 
folklooris (M. Kõiva) ja astraalmüütidest "From Moon to Great Wain" (A. Kuperjanov).

Inimeste ja loomade suhetest kõneleva folkloori alal valmisid uurimused "Contemporary dog-lore" ja "Contemporary Estonian pupil dog lore" (L. Vesik). Esimene uurimus vaatles muutusi rahvaluulemotiivides ja jutupärimuses 20. sajandi jäädvustuste valguses, sedastades muutused inimestele folkloori põhjal oluliste loomaliikide osas ning lemmikloomakultuuri laienemise eestlaste tavakultuuri sekka 20. sajandil. Teises käsitluses võrreldi 2007. aasta koolipärimuse näitel, milliseid tendentse peegeldab õpilaste koera-folkloor. Suhtumist putukatesse vaatlesid R. Sõukand ja R. Kalle: "From Repelling to Killing: Human-Insect Relationship in Estonian Folk Tradition".

T. Jonuks tegeles eesti usundi vanimate kihistustega - hiite teemal valmis uurimus "Changing meaning of Estonian hiis-sites" kogumiku "Archaeology of Spiritualities" jaoks ning "Isolated holy places - sites where nothing is around?" sarjale "Sacred sites around the Baltic Sea". Jätkus vanema usundi tõlgendamine ("Eesti usund muinas- ja keskaja piiril: olid nad kristlased või paganad?") ja tööd usunditerminoloogia alal (koos E. Orase ja K. Johansoniga "Terms and concepts in archaeology of religion"). Saagade-temaatika jätkus käsitlusega "Estonia in Old-Norse literature". Töös oli Kukruse kalmistu kogumik (sarjale "Muinasaja teadus"), millest valmisid arheoloogilise tausta ja uusaegse tee kohta käivad peatükid, kirjutamisel oli matuste detailne kirjeldus. Paljude kogumikku kavandatud teemade kohta on tellitud artiklid. Valmistati ette aprillis 2012 Oulus toimuvat Nordic TAGi sessiooni "Archaeology of holiness".

Grandi "Religiooni materiaalsus" (juht T. Jonuks, täitjad Kristiina Johanson Tartu Ülikoolist ja Ester Oras Cambridge'i ülikoolist) raames koostati aasta jooksul välilabor ja hangiti korralik pildistamisvarustus ning töötati läbi Võru, Valga, Viljandi, Pärnu, Paide, Rakvere, Narva ja Tartu linnamuuseumi kogud. Valmis Accessi-põhine andmebaas, leiud on enamasti kataloogitud. Valmis esimene grandiga seotud artikkel ("An antler object from Pärnu river - an axe, a god or a decoy") "Muinasaja teaduses", viidi 
läbi uuringuid unikaalsete leidude kohta (Kavastu lamp - E. Oras) ning kujunesid mitmed eriuurimuste teemad, mis peavad ootama, kuni kõikide muuseumide kogud on läbi vaadatud. Granditeemaga seoses kerkis üles usundialaste terminite ja nende kasutamise küsimus, millest oli ajendatud ka ettekanne Central TAGi konverentsil Birminghamis.

Komi keele ja kultuuri uuringutega jätkas N. Kuznetsov, kesksel kohal oli sel aastal komi keele uurimine, eeskätt kognitiivsest aspektist ja kohakäändeid aluseks võttes. Artikli "Периферийные употребления аппроксиматива в коми языке" teoreetiliseks taustaks on prototüübiteooria, mis võimaldab polüseemse keeleüksuse semantika suhteliselt paindlikku tõlgendamist. Prototüübipõhisel lähenemisel on võimalik seletada probleemsemaid fakte; selles konkreetses uurimuses on käsitletud ühe komi kohakäände perifeersemaid ruumitähendusi ja on antud mõnele neist uus seletus. Uurimuses "Местные падежи коми языка в когнитивном аспекте (на примере пространственных значений аппроксиматива)" on käsitluse teoreetiliseks taustaks kognitiivne grammatika. Oma uuemaid uurimistulemusi tutvustas N. Kuznetsov Eestis, Komis ja välismaal. Samuti jätkus olulisemate komi kultuuriuurimuste tutvustamine eesti keeles, muuhulgas valmis tõlge Galina Mišarina käsitlusest "Itkud komi matuse- ja tõrjekombestikus”. Jätkus M. Hoppáli “Šamaaniraamatu” tõlkimine ja toimetamine ning tema venekeelsete artiklite kogumiku toimetamine koostöös autoriga.

Jätkusid uuringud Bulgaaria Vabariigis seoses kahe riigi Teaduste Akadeemiate ühisprojektiga "Folklore and dynamics of identities in united Europe - the case of Bulgaria and Estonia". Valmisid käsitlused maskeerimisfestivalist Pernikus ja jätkuna pühapaikade uurimisele ülevaade Bulgaaria palverännakutest.

\section{Eesti ja läänemeresoome lühivormid}

Lühivormide alal kaitsti kaks doktoriväitekirja (A. Baran, "Eesti fraseologismide semantika uurimisvõimalused"; P. Voolaid, "Eesti mõistatused kui pärimusliik muutuvas kultuurikontekstis"). Oluliseks tulemuseks oli riikliku programmi "Eesti keeletehnoloogiline 
tugi" varal valminud "FES, Eesti fraseologismide elektrooniline alussõnastik" (A. ja K. Õim), mis sisaldab 20749 fraseologismi või lekseemi, mida on analüüsitud kognitiivse keeleteaduse põhimõtete alusel ja koondatud mõisteseoste järgi. Tegemist on algupärase mõistelise fraseoloogia alussõnaraamatuga, millesarnased varasemad sõnaraamatud eesti keeles puuduvad. Sõnastikus antav eesti fraseologismide terviklik semantiline, süntaktiline ja morfoloogiline kirjeldus võib olla lähtealuseks järgnevatele samasisulistele või muudele fraseologisme käsitlevatele sõnaraamatutele. Selles mõistelises fraseoloogiasõnaraamatus: 1) eksplitseeritakse fraseologismide tähendusi motiveerivate mõistemetafooride sihtvaldkonnad, 2) käsitletakse fraseologisme süntaktiliste üksustena ning 3) eksplitseeritakse fraseologismide morfosüntaktiline struktuur. FESist on fraseologisme lihtne leida ka siis, kui kasutaja ei tea, millist konkreetset sõnaühendit või selle vormi otsida, kuid suudab otsitavat seostada näiteks mõne ontoloogilise mõistekategooriaga. FES koondab 26813 tähendusüksust, mis järjestatakse mõisteartiklites morfosüntaktilise struktuuri järgi. FES sisaldab ümmarguselt 80000 sõnet ja suhteliselt piiratud hulka (pisut üle 6000) tüvesid; erisuguseid grammatilisi vorme leidub ligi 70. Lisaks on FESi põhjal eristatud rohkem kui 5800 morfosüntaktilist malli, mis koosnevad tüüpiliselt kahest kuni kolmest osisest ja paistavad hinnanguliselt olevat suuresti samasugused kui mitteidiomaatilises keeles.

Suuremaks saavutuseks võib lugeda veel K. ja A. Õimu kaheosalist artiklit Eesti fraseoloogia leksikograafilisest arengust, mille esimene osa ilmus ajakirjas Keel ja Kirjandus 2008. ja teine 2011. aastal. Artikli fookuses on eesti idiomaatilise mõtte arenemine.

Eesti fraseologismide semantikast kaitses A. Barani doktoriväitekirja, mille pikem teoreetiline osa käsitles psühholingvistilisi ja sotsiolingvistilisi uurimissuundasid, mis võimaldavad senisest paindlikumat fraseologismide analüüsi. A. Baran tõi oma väitekirjas keskse mõistena esile salientsuse - salientsed tähendused on need, mis on mälus alati esimestena kättesaadavad, olgu kaasaaitavaks teguriks sage kasutus, kogemuslik tuttavlikkus, kontekst vm. Teoreetilisele osale järgneb viis artiklit, milles vaadeldakse: a) traditsiooniliste fraseoloogiliste ühendite lühidust ning konteks- 
tisidusust muutuste skaalal; b) eestikeelsete fraseologismide teket ja nende saksakeelset, religioosset tausta; c) fraseologismide rolli Eesti koolinoorte keelekasutuses; d) loomametafoore sisaldavaid sõimuväljendeid; e) hüperboolseid fraseologisme.

A. Barani uurimistöö põhiteemaks on jätkuvalt olnud ka kujundlik keelekasutus internetikeskkonnas, sh meediakeel ja fraseoloogia; jätkuvad uurimused vanema fraseoloogia ja vanasõnade rollist noortesuhtluses, samuti vanemas fraseoloogias kajastuvad keelesümbolid ja nende motivatsiooni tagav teadmus. Valmisid artiklid "Piltlikkuse rollist fraseologismi mõistmises", "New life of proverbial expressions", "Sooline aspekt eesti fraseoloogias", "On the semantic ambiguity of phraseologisms", "On the role of phraseologisms in the Estonian online media", "On the role of visual imagery in comprehension of phrases - New media. Multimodal texts - visual humor of Internet". Lisaks sellele toimetas A. Baran konverentsi "Keelest meeleni / From Language to Mind 3" ettekandeid trükis avaldamiseks.

Seoses Poola-Eesti koostööprojektiga koondus P. Voolaiu huvi grafiti-ainesele ja selle seostele paröömika ehk ütlusfolklooriga, valmisid väljundettekanded ja artiklid "Paröömiline pilguheit Tartu avalikku linnaruumi" / "Paremiological insight into the publik city space of Tartu" ja "In graffiti veritas". Samuti valmis P. Voolaiul tellimuskogumik "Elu on lill, ainult kasta. Kõnekäände inimesest ja elamisest" (Tallinn, Ajakirjade Kirjastus).

A. Krikmann redigeeris oma artikli "Kommentaare mõnedele folkloorse või rahvapärase taustaga proosapaladele (Observations on traditional or folk tales appearing in the Berlin recordings of Estonian speech)" ingliskeelset tõlget Jaan Rossi koostatavasse kogumikku "Encapsulated Voices. Estonian Sound recordings from the World War One in Berlin Archives: Estonian Sound Recordings from the German Prisoner-of-War Camps in 1916-1918”. Valmis uurimus "Armastus kui teema ja mõiste eesti jm vanasõnades ja mõnes muus folklooris", samal teemal pidas ta ka loengu Tartu Ülikoolis.

"Eesti mõistatuste" III köite jaoks lõpetas A. Krikmann lahendite registri põhiastme kirjete koostamise (algvariandi pikkuseks 
kujunes 70 lk) ja koostas statistilise kokkuvõtte eesti mõistatamisobjektide mõistelise jagunemise kohta (u samades lõigetes nagu raamatus "Sissevaateid folkloori lühivormidesse", kuid kogu allikmaterjalis nähtuvat polüseemiat arvestades). Toimusid alustööd eesti mõistatuste (lahendite) polüseemia osas, valmis esialgne statistiline koond võimalike mõistedomeenides osas. Samuti valmis A. Krikmannil referaat, kus on ainestikus (Archer Taylori raamatu "English Riddles from Oral Tradition" põhjal) ning eesti allikmaterjalis võrreldud 66 tüüpi või tüübisülemit.

Mõistatuste kujundite-osa jaoks kopeeriti välja tekstiread, kus on tegemist a) inimkujunditega, b) loomkujunditega, c) taimkujunditega, d) artefakte esindavate kujunditega - kas siis otse substantiividega või neisse mõisteregioonidessse assotsieeruvate verbide, adjektiivide vm sõnadega. Paralleelide registri osas valmis statistika ja kartogrammid soome, ingeri, karjala, vadja, isuri, vepsa, liivi, läti ja vene mõistatusvastete seosetiheduse kohta Eesti kihelkondade materjaliga. Ühisosade suurused registreeriti tüübihulkades. Ühtlasi korrastati ja vormistati lõplikult viited laiemale rahvusvahelisele ainesele Taylori raamatu "English Riddles from Oral Tradition" põhjal. Jätkus töö kogujate registriga (A. ja L. Krikmannn, R. Saukas).

Mõistatuste piirialade teemal valmis P. Voolaiul doktoritöö "Eesti mõistatused kui pärimusliik muutuvas kultuurikontekstis". Väitekirjas keskenduti mõistatusliikide sotsiokultuurilisele tähendusele. Ilmusid artiklid "Why is the floor squeaking? Because the wiser one gives in: On relations between Estonian conundrums and paremiology", "On the relations between joking questions and paremiology - proverbs in the service of humour creation", "Recent developments in pupils' riddle usage in Estonia" ja "Recent changes and reflections of true life events in Estonian riddles".

\section{Multimeedia ja huumoriuuringud, internet}

L. Lainestele oli peamiseks väljakutseks töö 11. rahvusvahelise huumori suvekooli ja sümpoosioniga (International Summer School for Humour Studies: Research, Theory and Applications (ISS11)), mis korraldati koostöös Eesti Kirjandusmuuseumiga Tar- 
tus 15.-20. augustini 2011 (vt http://www.humoursummerschool. org/11/) ja mis tõi Eestisse hulgaliselt maailmanimega huumoriuurijaid (psühholooge, sotsiolooge, lingviste jt). Suvekooli läbiviimist toetasid Eesti Kultuurkapital, Tartu Kultuurkapital, Eesti Kirjandusmuuseum, Eesti Teaduste Akadeemia, Saksa Suursaatkond, ISS Advisory Board jt. Suvekooli eesmärk oli pakkuda sissejuhatust huumoriuurimise distsipliini ning sügavamaid sissevaateid huumori ja naeru uurimisse.

Eri uurimisvaldkondi esindavaid lektoreid osales suvekoolis 13. See tagas suurepärase programmi, mis oli mitmekülgne ja interdistsiplinaarne. Lisaks sellele osalesid kõik lektorid aktiivselt tudengite juhendamise hommikustes sessioonides kogu nädala jooksul (13./14. august - 21. august). Suvekooli programm oli koostatud selliselt, et kaetud oleksid nii teoreetilised kui ka empiirilised küsimused. Igapäevased metodoloogialoengud avardasid kuulajate mõistmist huumori uurimises kasutatavatest meetoditest.

Suvekoolist võttis osa 28 delegaati. Nende hulgas oli üliõpilasi, doktorante, ülikoolide teaduslikke töötajaid, järeldoktorante, aga ka huumori praktiliste väljunditega kokku puutuvaid inimesi (neurolooge, psühholooge, ettevõtjaid jt). Osavõtjaid oli Austriast, Austraaliast, Belgiast, Taanist, Suurbritanniast, Eestist, Saksamaalt, Soomest, Islandilt, Itaaliast, Lätist, Malaisiast, Norrast, Poolast, Venemaalt, Šveitsist ja USA-st. Akadeemilistest distipliinidest olid esindatud psühholoogia, antropoloogia, lingvistika, sotsioloogia, folkloristika, amerikanistika jm. Delegaatide mitmekülgne taust oli suureks plussiks grupidiskussioonides.

Toimus ka iga-aastane delegaatide sümpoosium, millest võttis osa 15 delegaati. Kirjastus Mouton de Gruyter sponsoreeris esinejaid auhindadega, mille said Maria Goeth, Bastian Mayerhofer, Tracey Platt ja Piret Voolaid.

ISS11 osutus igati kordaläinuks (seda ka tagasisideküsitluse kohaselt, mille korralduse ja sisulise keskmine hinne oli viiepallisüsteemis 4,68). Osalejad kiitsid loengute kõrget akadeemilist taset, aga ka toimumispaika ning sotsiaalsete ürituse korralduslikku poolt. Loengute väliselt toimus aktiivne suhtlus ja kontaktide vahetamine, millest on loota edaspidist teaduslikku koostööd. 
Edukalt liigub edasi Eesti ja Poola teaduste akadeemiate vaheline projekt "Creativity and Tradition in Polish and Estonian Cultural Communication", mille raames korraldati oktoobris 2011 Poolas konverents, millest võttis osa 6 Eesti teadlaste esindajat, lisaks neile peeti 4 võrguettekannet spetsiaalse loengukeskkonna kaudu. Vastuvisiidil käisid Tartus W. Chlopicki ja D. Brzozowska (augustis 2011) ning W. Zarski (septembris 2011). Järgmisel aastal on plaanis külastada Krakowi ülikooli ISHSi konverentsi ajal (25.29. juunini).

Tihenemas on ka koostöö Rumeenia teadlastega (eesotsas Diana Popaga), kellega on kavas asutada Ida-Euroopa huumorile keskenduv teadusajakiri, mille toimetusse kuulub edaspidi L. Laineste.

Grandi "Kultuuriprotsessid muutuvas ühiskonnas: Traditsioon ja loovus postsotsialistlikus huumoris" (L. Laineste) raames oli ettevalmistamisel kolm Eesti-Poola artiklikogumikus ilmuvat artiklit, mis on peamiselt materjali kogumise järgus. Neist ühel teemal valmis ettekanne "Women in Estonian family jokes", milleks kategoriseeriti seni kategoriseerimata materjali eesti nüüdisaegsete anekdootide andmebaasis ja tutvuti kirjandusega. Töötati ka materjalidega, mis on vajalikud artikliks eesti stand-up-ehk püstijalakomöödiast (koostöös juhendatava Ilona Piirimägiga); valmimas on selle eestikeelne versioon. Kolmanda artikli teemaks on leim ja vihakõne internetis. Lisaks olid töös “"Vähe peksti meid, lolle!": Sovetiaeg postsotsialistlikus huumoris" (käsitleb uuemat telesarja "ENSV") ja artikkel blogikultuurist kui alternatiivajakirjandusest ning huumori rollist selle žanri populariseerimisel. Populariseerival suunal ilmus artikkel "Anekdoot - eesti huumori dinosaurus" Õpetajate Lehe kvartalikirjas Haridus, kus autor tutvustab oma doktoritöö põhitulemusi ja analüüsib anekdoodi kui žanri staatust ja toimimist tänapäeva ühiskonnas.

Avaldamisootel on L. Laineste uurimus "Politics of taste in a post-socialist state: A case study" (Tsakona ja Popa kogumikus "Confronting Power with Laughter"). Kogumiku üldeesmärk on kirjeldada poliitika ja huumori vahekorda erisugustes kultuurikontekstides, et teha üldistusi ja järeldusi sotsiaalse keskkonna mõjude kohta huumorikasutusele. Sellele otsib vastust 11 peatükki, 
mis on jagatud kolme teemarühma: poliitikute huumor, huumor meedias ning huumori roll avalikus poliitilises debatis. Viimasesse teemaderingi kuulub ka L. Laineste artikkel, mille põhieesmärgiks on analüüsida 2007. aastal toimunud poleemikat rassistlike naljade kohta eesti laste kohustuslikus lugemisvaras. Artiklis vaadeldakse tekkinud avalikku diskussiooni, milles saavad sõna nii rassismi ja naljade ühisosa tunnistavad kui seda eitavad pooled; nende dialoogis konstrueeritakse/defineeritakse huumori mõiste. Sellised kokkupõrkeid võib tulevikus rohkemgi oodata, sest poliitilise korrektsuse nõue süveneb, samal ajal mõjutab suhtumist sellesse oluliselt Eesti kui endise idabloki riigi minevik. Interaktsioonis minevikuga tekibki kujutlus lubatud ja lubamatust naljast ning selles keskkonnas püsib huumori definitsioon üsna avarana, mahutades enda alla ka mõnes teises sootsiumis lubamatu nalja.

Artiklis "Eastern European three-nation jokes: A beta database" (L. Laineste ja D. Brzozowska) rõhutatakse rahvuslike, eriti aga rahvusvaheliste huumori-andmebaaside tähtsust nii folkloristlikus kui ka interdistsiplinaarses plaanis, sh senisest kiiremaid ja paindlikumaid võimalusi ainese kvantitatiivseks analüüsiks (mis võiksid olla sisse ehitatud otsimootorisse ning veebipõhisena kättesaadavad kõikidele uurijatele), tugikohti rahvusvahelise naljarepertuaari ühtse kategoriseerimissüsteemi väljatöötamiseks, ajendeid semantiliste otsimootorite arendamiseks. Folkloorse huumori rahvusvaheline andmebaas võimaldaks hinnata naljakategooriate proportsioone eri maades, nende ajalist dünaamikat, traditsiooni ja innovatsiooni vahekordi, sotsialistliku ja demokraatliku lähiminevikuga traditsioonide erinevust jne.

A. Krikmann valmistas ette kaks ettekannet/uurimust/loengut: "Relationships of punchlineless (and in general older) "Schwanks" and contemporary punchlined jokes ("Witzes")" ja "Estonian "three-nation" jokes (1964-2011)".

Grandi "Kultuuriprotsessid Interneti kogukondades. Narratiivid, väärtushinnangud ja kohaloome" (M. Kõiva) raames koguti ainestikku lemmikloomakultuuri, meediumide/etnomeditsiini teemadel, foorumite narratiive ning geopeituse ainestikku. 
M. Kalda kirjutas uurimisartiklit geopeitusest (esialgne pealkiri "Infoajastu variandirikas mäng"). Selleks on töötatud vastava kirjandusega (kommunikatsiooniteooriad, mobiilsus, inimsuhete eripärad globaliseerumise ja infotehnoloogia ajastul; geopeituse analüüsid informaatika, meedia- ja kommunikatsiooniuuringute, kultuurigeograafia jt vaatepunktidest). Jätkati andmete koondamist keskkonnas geopeitus.ee kajastatava põhjal. M. Kõiva ja A. Kuperjanov valmistasid ette uurimust "The Druzhe Tito Figure in YouTube”, milles tulid käsitlusele eri sõnumiga dokumentaalsed, paroodilised ja poliitfantaasia stiilis klipid ning sarnaste intertekstuaalsete lugude võtted, üldnarratiivi loomise võtted ning vaatajate tagasiside narratiividele. Kirjutati käsitlusi meditsiininarratiividest (vt eespoolt) ja eepostega seotud intertekstuaalsusest ja intermediaalsetest narratiividest (M. Kõiva, A. Kuperjanov), samuti uusimatest tendentsidest lemmikloomapärimuses (L. Vesik). Jätkus tüdrukute kirjalike juttude jälgimine (E. Kalmre). Tähelepanu pälvisid kujundkõne ja narratiivid (vt lühivormid, P. Voolaid). Ettevalmistamisel oli uurimus muuseumide ja arhiivide osast kohaliku ajaloo ja väärtuste peegeldaja ja taasjuurutajana ning vastavatest refleksioonidest Bulgaaria näitel (M. Kõiva). Tegeldi veel andmebaasidele ühtsete standardite väljatöötamise, digiteeritud andmekorpuste presenteerimise ja nende turvalise arengu tagamisega. Toimetamisel oli kogumik "Maailm ja multitasking" (koostaja M. Kõiva), mis sisaldab valiku grandi raames valminud uurimusi. Ettevalmistamisel on L. Fialkova ja M. Jelenevskaja artiklikogumik.

\section{Arvutiandmebaasid, rakendus- ja arendusprojektid}

Sihtfinantseeritavale teemale eraldati miniinfrastruktuuri kaasajastamise toetus, mis on mõeldud ennekõike serveri laienduse soetamiseks, folkloristidele sobiva tarkavara soetamiseks ning mõne uue (soovitavalt Euroopa ainestikku ühendava) andmebaasi soetamiseks (vt http://www.folklore.ee/rl/fo/tegevus/thnl.htm). 
Osaleti ERMi püsinäituse tegemisel konsultantidena (E. Kalmre, A. Kuperjanov, M. Kõiva). Oldi aktiivselt tegevad ARSi töös hoidmise ja ürituste korraldamisega (E. Kalmre, M. Kalda, R. Saukas).

Rakendusprojektidest olid töös a) Võrumaa andmebaas ja portaal LEPP, mille heaks liigitati, kontrolliti, märgendati kõiki pärimusliike esindavat Võrumaa kihelkondade materjali, arendati Põlva, Hargla, Urvaste, Karula kihelkondade ja Antsla linna ajaloolisi ülevaateid (S. Kajak, E.-K. Kärblane, M. Kõiva, A. Kuperjanov, väljundid Antsla 1926, fotod 2011: http://www.folklore.ee/ pubte/v6rumaa/urvaste/antsla.htm ja Urvaste 1926, fotod 2011: http://www.folklore.ee/pubte/v6rumaa/urvaste/); b) "Sõrve pärimuse jäädvustamine ja kogumiku "Sõrvemaa jutud ja laulud" koostamine ning kirjastamine" - kirjutati kogumislugu, toimusid ettekanded kogumisest ja esitajatest, pärimuse üldisest staatusest ja arenguprotsessidest (rahastas programm "Saarte pärimuslik kultuurikeskkond", juht E. Kalmre).

Andmebaaside täiendamine ja nende tarvis ainestiku digiteerimine on sisuliselt kõikide osakonna töötajate igapäevatöö. Alljärgnevalt põgusalt sellesuunalistest edusammudest.

Väljendite andmebaasi (EKFA) ja selle põhjal valmiva fraseologismide allikpublikatsiooni "Monumenta Estoniae Antiquae" heaks töötas A. Baran läbi vanasõnade nn reservi jäetud osa, milles leidus hulk kõnekäänutüüpe. Ühtekokku lisandus ligi 70 tüüpi, suurimad neist saja sedeliga. Lisatud on vanema kirjanduse viiteid kõnekäändude esmaesinemuse kohta (Kreutzwald, Jannsen). Samuti on juhendatud ja korrastatud lisasisestusi, lisatud naljandite, muinasjuttude ja laulude viiteid andmebaasi lisainfo välja. Naljandite puhul on aluseks R. Põldmäe ja S. Läti vastavad väljaanded, kartoteek, lauluparalleelide puhul regilauluandmebaas. Tulemusena on küsimärgistatud tüübid saanud täpsustavad selgitused, mis aitab määratleda nende kõnekäänulisust.

L. Laineste on jätkuvalt tegelenud eesti naljade andmebaasi (http://haldjas.folklore.ee/ liisi/o2) täiendamise ja haldamisega.

Töö raames andmebaasiga HERBA (Historistlik eesti rahvameditsiini botaaniline andmebaas, R. Sõukand ja R. Kalle) valmis kirjanduse andmebaas, millesse on sisestatud ja liigitatud vanemat 
kirjandust, seni 8 raamatut (R. Sõukand). Kontrollitud on tekste EFA I ja II käsikirjalisest kogust (R. Kalle), sisestatud ERAst ja RKMist järelkontrolli käigus uusi tekste umbes $50 \mathrm{lk}$ (R. Kalle), lõpetatud on G. Vilbaste käsikirjalises kogus leiduva etnobotaanilise ainestiku sisestamine andmebaasi (R. Kalle). Vilbaste käsikirja jäänud võõrkeelsete taimenimede ja seente-sammalde registritest on sisestatud HERBAs seni puudu olevaid taimenimesid ja liigitatud nende alla tekste (R. Kalle). Kultuurkapitali toel skaneeriti vanemat ravimtaimekirjandust ja olulisemaid käsikirjalisi köiteid (EKS c, Lääts) (Aivar Jakobson), toimetati tekste (Tuul Sepp).

Keerdküsimuste andmebaasis (www.folklore.ee/Keerdkys) ja piltmõistatuste andmebaasis (www.folklore.ee/Reebus) toimus 2007. aasta kogumisvõistluse ainese tüübisisene korraldamine ja sisestamine - u 1000 keerdküsimust, tervenisti on lisatud Aimo Kejoneni raamatus "Sajandinaljad" (2005) leiduvad keerdküsimused (P. Voolaid). Algas uue andmebaasi "Grafiti" loomine (koostaja P. Voolaid, tehniline teostus Martin Jaakson), kuhu sisestati 200 üksust.

Valmis andmebaasi "Eesti loitsud" struktuur, sisu kuvamise ja uurija töövahendite kavandid, samuti selle laiendused võõrkeelse ainestiku ja teiste rahvaste ainestikuga sidumiseks. Sisestati loitse käsikirjadest ERA (kuni ERA II 250), Hurt (sarjad I, II, III, E.-K. Kärblane, S. Kajak), materjal on märgendatud ja kontrollitud (M. Kõiva).

Grandi "Religiooni materiaalsus" raames valmis andmebaas usundilistest esemetest Eesti arheoloogiakogudes.

2007. aasta koolipärimusest digiteeriti täielikult lemmikloomapärimus ja hirmujutud (M. Kõiva, S. Kajak, E.-K. Kärblane, E. Fridolin).

Akadeemilistest muistendiväljaannetest viimistleti halltõvepärimuse köidet (P. Paal, M. Kalda). Jätkus muistendite ja usunditekstide sisestamine ja kontrollimine (ERA käsikirjalised kogud: M. Kalda, K. Kikas, S. Kajak) ning jätkati Hurda kogudele sisestusnimestike koostamist, sealt loitsude sisestamist ja kontrollimist (K. Kikas, M. Kõiva, E.-K. Kärblane). Täiendati puude andmebaasi (M. Kuperjanov). 
Liideti e-arhiiviga projekti RADAR sisestusi (H. Hanni). Teoreetiliste osade, struktuuri ja tüpoloogiaga tegeldi kõigi töösolevate teemade ulatuses. Kultuurkapitali toel algas eesti kalendrikirjandusest rahvajuttude ja -usunditeadete digiteerimine esimestest kalendritest kuni aastani 1945 (peamiselt M. Villandi).

Ilmusid eelretsenseeritavad e-ajakirjad Folklore: Electronic Journal of Folklore (nr 47-49) ja Mäetagused (nr 47-49). Ingliskeelse ajakirja 2009. aasta rahvusvahelist suhtlust toetas riiklik programm "Eesti keel ja rahvuslik mälu”. Ajakirja Mäetagused trükkimist rahastas Eesti Kultuurkapital. Perioodiliste väljaannetega töötasid A. ja M. Kuperjanov, M. Kõiva, M. Leman, M. Kuperjanov, A. Niinemets, P. Voolaid. Lisaks Thomson-Reutersi andmebaasile (ISI WEB) indekseeris ja vahendas mõlemat ajakirja EBSCO andmebaas "Humanities International Complete", ühtlasi saavutati mõlema ajakirja lisamine ERIHi süsteemi.

Lisaks ajakirjade e-numbritele valmistati 5 uut e-raamatut (M. Kuperjanov, A. Kuperjanov jt), võrku pannakse uudislehte FOAFTale News (E. Kalmre, tehniline tugi L. Vesik).

\section{Välitööd}

Lasteaiapärimuse kogumisvõistluse (www.folklore.ee/kp/lp) eestvõtja P. Voolaiu mahukale, avatud vastustega küsitluskavale vastas ligi 80 õpetajat-kasvatajat lasteaedadest üle Eesti. 67 kaastöö hulgas oli 62 individuaalvastust ja 5 kollektiivset tööd. Peale Lääne- ja Viljandimaa olid esindatud kõik maakonnad. Osavõtjate hulgas olid peamiselt praegused lasteaednikud, kuid oli ka neid, kes enam lasteaias ei tööta. Lühim vastus oli kiri üheainsa mõistatusega, pikimad ulatusid aga poolesaja leheküljeni ja paistsid silma heade teemajutustuste ning rohke foto- ja videomaterjaliga. 2011. aastal tehti aktsioonist kokkuvõtteid ning materjalid ja preemiad anti üle 14. märtsil.

P. Voolaid jäädvustas grafitit Tartus ja mujal Eestis.

Etnobotaanikud korraldasid küsitluse "Lapsepõlves söödud looduslike taimede pärimus", mille esialgsetest tulemustest valmis 
ka kaks ülevaateartiklit (kirjandusmuuseumi aastaraamatus ja Eesti Looduses, R. Kalle, R. Sõukand).

7. mail jäädvustati Qbajjari lahe kaldal Gozol (Ghawdex) asuvas Marsalforni kalurikülas külapidu ja 15. mail Dingli laata (M. Kõiva, A. Kuperjanov).

Aasta jooksul jäädvustati Lõuna-Eesti portaali LEPP jaoks fotovälitöödel Urvaste kihelkonnas ja Antslas kirikuid, kabeleid, kultuurikeskusi, koolimaju, valitud kodusid ja koduaedasid, skulptuure ning teemaparke Pokumaad, Nõiariiki, Metsamoori pereparki. 22. juunil jäädvustati Metsamoori taimeetendus (M. Kõiva, A. Kuperjanov).

8.-19. oktoobrini oli A. Baran välitöödel Ida-Saaremaa ja Muhumaa koolides (projekt "Saaremaa ja Muhumaa koolinoorte fraseoloogia-alane küsitlus") kultuuriministeeriumi toetusprogrammi "Saarte pärimuslik kultuurikeskkond 2011-2014" raames.

4.-13. detsembrini viibisid M. Kõiva ja A. Kuperjanov Eesti ja Bulgaaria Teaduste Akadeemiate ühisprojekti raames välitöödel (küsitlused lokaalse ajaloo kajastamisest, kloostritest kui traditsioonide sõlmpunktidest, arheoastronoomilistest monumentidest, tähtpäevakombestikust) marsruudil Russe, Kazanlak, Plevna, Šipka.

\section{Näitused}

1. aprillist 30. detsembrini oli Tartu Ülikooli Ajaloo Muuseumis avatud näitus "Kukruse kaunitar ja tema kaasaegsed: Eesti rikkalikem kalmistu muinas- ja keskaja piirilt”. Näituse kuraatorid olid Mari Lõhmus ja T. Jonuks, kujundajad Liina Unt ja Katre Rohumaa. TÜ ajaloo muuseumi ja kultuuriteooria tippkeskuse ühistööna valminud näitus otsis vastuseid küsimustele: kes olid need inimesed, keda maeti Kukrusele; kuidas ja millal neid sängitati; milline oli surnute rõivastus; kas Kukrusele maeti sõjamehi; kas nad olid kristlased. Tutvuda sai ka arheoloogide tööoludega: alati ei toimu kaevamised suvel, Kukrusel kaevati 
käredate miinuskraadidega 2009. aasta lõpus ja 2010. aasta alguses kõrgete lumehangede vahel. Arheoloogilised kaevamised tõid päevavalgele umbes 800 -aastase kalmistu, mis koosnes viiekümnest matusest.

14. mail esitleti muuseumiöö "Öös on aardeid" raames slaidiprogrammi "Kaitseesemed öös” (M. Kõiva, A. Kuperjanov).

6. augustil avati konverentsil "Läänemere isandatest tänaseni sõrulase tee muutuvas argipäevas" Salme rahvamajas E. Kalmre koostatud näitus "Sõrvemaa paigad ja inimesed" (kujundanud Artur Kuus).

23. septembrist detsembrini oli EKMi trepigaleriis avatud M. Kõiva ja A. Kuperjanovi fotonäitus "Surva".

Linnaraamatukogule vahendati Renaldo Veeberi näitus "Eesti mütoloogia” (A. Niinemets).

\section{Kraadiõpe}

\section{Doktorikraadid}

Piret Paal kaitses 15. jaanuaril Helsingi Ülikoolis väitekirja "Written cancer narratives: An ethnomedical study of cancer patients' thoughts, emotions and experiences", juhendajad A. Kaivola-Bregenhoj, M. Naakka-Korhonen, A.-L. Siikala (kuni 2009), oponendid Ilkka Haarni ja Kirsti Salmi-Niklander.

Anneli Baran kaitses 15. märtsil Tartu Ülikooli kultuuriteaduste ja kunstide instituudis doktoriväitekirja "Fraseologismide semantika uurimisvõimalused", juhendaja Arvo Krikmann, oponent Outi Lauhakangas.

Mare Kalda kaitses 30. mail Tartu Ülikooli kultuuriteaduste ja kunstide instituudis doktoriväitekirja "Rahvajutud peidetud varandustest: tegude saamine lugudeks", juhendaja Jürgen Beyer, oponendid Tiina Peil ja Irma-Riitta Järvinen. 
Piret Voolaid kaitses 30. juunil Tartu Ülikooli kultuuriteaduste ja kunstide instituudis doktoriväitekirja "Eesti mõistatused kui pärimusliik muutuvas kultuurikontekstis (Estonian riddles as a folklore genre in a changing cultural context)", juhendajad Arvo Krikmann ja Tiiu Jaago, oponendid Mall Hiiemäe ja Sirkka Saarinen.

\section{Magistrikraadid}

31. mail kaitses folkloristika osakonna töötaja Kaisa Sammelselg etnoloogia alal magistritöö "Maausulised 21. sajandi alguse Eestis: analüüs läbi hiie problemaatika", juhendajad Art Leete ja Tõnno Jonuks, retsensent Ergo-Hart Västrik.

Doktoriõppes jätkasid Katre Kikas, Nikolay Kuznetsov, Raivo Kalle, grandilistest Martin Rebane ja Kristiina Johanson.

\section{Juhendamine}

T. Jonuks juhendas Tuuli Kurisoo bakalaureusetööd "Ristripatsid Eesti 12.-13. sajandi laibakalmistutes - ehted, kristlaste või paganate tunnused" (kaitsti 2011).

T. Jonuks juhendas koos Martin Malvega Liivi Varuli bakalaureusetööd "Rituaalselt kasutatud inimluud Eesti noorema pronksiaja kalmistutes".

T. Jonuks juhendas koos Marge Konsaga Tuuli Kurisoo magistritööd "Ristisümboolika Eesti hilisrauaaja materjalis".

T. Jonuks juhendas koos Aivar Kriiskaga Kristiina Johansoni doktoritööd "Sekundaarselt kasutatud esemed Eesti arheoloogias".

T. Jonuks juhendas koos Meelis Friedenthaliga Raivo Pranki doktoritööd "Mõõk religioosse sümbolina 8.-13. sajandi Euroopa inimese maailmapildis".

N. Kuznetsov juhendas koos Florian Siegliga Triin Todeski bakalaureusetööd "Verbi augmentatiivne võrdlusaste komi keeles" (kaitsti 2011). 
P. Voolaid juhendas Eleene Sammleri bakalaureusetööd “Eesti laste kirjad jõuluvanale: soovid traditsiooni keskmes” (kaitsti 2011).

R. Sõukand juhendas koos Ain Raaliga Sofia Hratkevitši magistritööd "Ravimtaimede ja rahvameditsiini võtete kasutamine gripi ja külmetushaiguste korral Kuressaare ning Tallinna apteegikülastajate poolt" (kaitsti 2011).

R. Sõukand juhendas koos Ain Raali ja Daisy Volmeriga Anna Abolinši magistritööd “Ženšenni preparaatide kasutamine Eestis" (kaitsti 2011).

R. Sõukand juhendas koos Väino Pikalaisega Raivo Kalle doktoritööd "Looduslikud toidutaimed Eesti etnokultuuris ning nende võimalik rakendamine tänapäeval”.

\section{Oponeeringud}

K. Kikas oponeeris Karoliina Sarki (Tallinna Ülikool, germaani-romaani filoloogia) magistritööd "Norra rahvajuttude tõlkimine eesti keelde raamatu "Hedaleni metsa trollid" näitel".

\section{Konverentsid, seminarid, loengud}

\section{Korraldatud ürituste kroonika}

3. ja 4. veebruaril korraldas folkloristika osakond Jõgevestel Eesti folkloristide 6. talvekonverentsi "Haldjas 15: pärimus ja internet". Ettekanded: Aado Lintrop, Lina Gergova, Ell Vahtramäe, Tiiu Jaago, Kadri Tüür, Asta Õim, Mare Kõiva, Ingrid Rüütel, Reet Hiiemäe, Maili Pilt, Mare Kalda, Anneli Baran, Liisi Laineste, Piret Voolaid. Posterettekanne: Sille Kapper. Konverentsil esitleti Ingrid Rüüli Kihnu tantsude DVD-d, Janika Orase Saaremaa rahvalaulude veebikogumikku "Söit, söit, söit Sörve poole", Piret Paali raamatut "Written Cancer Narratives - An Ethnomedical Study of Cancer Patients' Thoughts, Emotions and Experiences". Konverents lõppes ekskursiooniga Barclay de Tolli mausoleumi. 
Teesid ja muu informatsioon leitav aadressil http://www.folklore. ee/rl/fo/konve/2011/ftk6/.

15.-20. augustini korraldas Liisi Laineste ISHSi 11. rahvusvahelise suvekooli ja sümpoosioni "International Summerschool and Symposium for Humour and Laughter: Theory, Research and Applications" (ISS11). Lektoritena astusid üles Dorota Brzozowska, Wladislaw Chlopicki, Christie Davies, Holger Kersten, Arvo Krikmann, Alexander Kozintsev, Seppo Knuuttila, Sharon Lockyer, John Morreall, Anu Realo, Graeme Ritchie, Willibald Ruch, Clare Watters, Liisi Laineste; ettekannetega: Piret Voolaid, Martin Rebane.

28. ja 29. oktoobril korraldas Liisi Laineste koostöös Poola partneritega Krosnos (Poola) Poola- Eesti ühiskonverentsi "Creativity and Tradition in Polish and Estonian Cultural Communication". Ettekannetega astusid üles Eve Annuk, Anneli Baran, Risto Järv, Mare Kalda, Eda Kalmre, Arvo Krikmann, Mare Kõiva, Liisi Laineste, Maarja Lõhmus, Indrek Ojam, Ilona Piirimägi, Martin Rebane ja Piret Voolaid.

17. ja 18. novembril Eesti Kirjandusmuuseumis ja Eesti Rahva Muuseumis alushariduse keeleõppe koolitusseminar "A-B, hakka pähe! Kui ei hakka, lükkan takka!”. Seminari korraldasid Haridus- ja Teadusministeerium, Eesti Rahva Muuseum, Eesti Kirjandusmuuseum, Eesti Rahva Muuseumi Sõprade Selts, Emakeele Selts, muuseumi esindajana Piret Voolaid.

28. novembril korraldasid Mare Kõiva, Liisa Vesik ja Renata Sõukand 8. interdistsiplinaarse konverentsi "Medica: Medical Pluralism in the Era of Digimodernism”; esinesid Mihály Hoppál, Valentina Haritonova, Tatjana Bulgakov, Kaarina Rein, Mare Kõiva, Svetlana Tsonkova, Kristiina Johanson, Ave Tupits, Raivo Kalle ja Renata Sõukand, posterettekanne Piret Paalilt.

28.-30. novembrini osales Eda Kalmre kaaskorraldajana Vilniuses Leedu Kultuuriuuringute Instituudi korraldatud rahvusvahelisel konverentsil "Cultural Research in the 21st Century: Heritage, Identities and New Rhetoric". 
29. ja 30. novembril peeti Tartus Eesti Kirjandusmuuseumi, Tartu Ülikooli kultuuriteaduste ja kunstide instituudi ning Kultuuriteooria tippkeskuse sümpoosion "Traditional and Literary Epics of the World: Textuality, Authorship, Identity”, mis oli pühendatud Eesti rahvuseepose "Kalevipoeg" 150. aastapäevale. Korraldustoimkonnas olid Mare Kõiva, Marin Laak, Risto Järv, Mare Kalda, Katre Kikas, Maris Kuperjanov, Salle Kajak.

22. detsembril korraldati Eesti Kirjandusmuuseumi Kreutzwaldi päevade rahvaluulepäev, esinesid Reet Hiiemäe, Märt Läänemets, Vladimir Sazonov, Heinike Heinsoo, Enn Ernits, Sirje Kupp-Sazonov, Renata Sõukand ja Raivo Kalle, Mare Kõiva, Anu Korb.

\section{FO töötajate ettekanded}

3. ja 4. veebruaril Eesti folkloristide 6. talvekonverentsil "Haldjas 15: pärimus ja internet" Jõgevestel: L. Gergova "Missing Stereotypes and Stereotypes in Excess", A. Õim "Mis on FES?", M. Kõiva "Koht ja paik loitsudes", R. Hiiemäe "Rollid ja rollikäitumine esoteerikafoorumites”, M. Kalda "Tagasi Tammiku Rahaaugumäele. Kas kohanimes on lugu sees?", A. Baran "Piltlikkuse rollist fraseologismi mõistmises", L. Laineste “"Vähe peksti meid, lolle!”: Sovetiaeg postsotsialistlikus huumoris", P. Voolaid "Paröömiline pilguheit Tartu avalikku linnaruumi".

8. ja 9. veebruaril rahvusvahelisel konverentsil "Инновационные технологии в сфере национального образования” Sõktõvkaris, Komimaal: N. Kuznetsovi videoettekanne "Преподавание коми языка в Тартуском университете”.

21.-25. veebruarini ISFNRi (International Society for Folk Narrative Research) vahekonverentsil "Telling Identities: Individuals and Communities in Folk Narratives" Shillongis, Indias: M. Kõiva "Serva Ell - how folk stories reflect the actions of a famous folk healer", Andres Kuperjanov "From Moon to Great Wain”, L. Vesik "Contemporary dog-lore". 
5. märtsil emeriitprofessor Anu-Reet Hausenbergi 70. sünnipäevale pühendatud seminaril Tallinnas: N. Kuznetsov "Komi uudissõnadest".

27. märtsil andsid R. Sõukand ja R. Kalle Vikerraadio teadussaates Labor ülevaate muutustest eestlaste ravimtaimede kasutamises, tutvustades artiklit, mis ilmus ajakirjas Journal of Ethnopharmacology (http://vikerraadio.err.ee/helid?main_id=1537301).

4.-8. aprillini konverentsil "Zoosemiotics and Animal Representations” Tartus: R. Sõukand, R. Kalle, Ingvar Svanberg "From Repelling to Killing: Human-Insect Relationship in Estonian Folk Tradition".

11. ja 12. aprillil ERMi 52. aastakonverentsil “Toidukultuur": R. Kalle ja R. Sõukand "Looduslike taimeliikide söögiks tarvitamine Eestis. Toidukultuuri kogumine ja vahendamine: individuaalsed ja institutsionaalsed vaatepunktid. / Recollecting and mediating food culture: individual and istitutional perspectives".

14. aprillil laste- ja noortekirjanduse konverentsil O. Lutsu nimelises Tartu Linnaraamatukogus: E. Kalmre "Tüdrukute omaloomingulised armastusjutud - pärimuskultuur ja/või kirjandus”.

15. aprillil Austmarr Network'i sümpoosionil "Cultural Exchanges Across the Baltic Sea in the Middle Ages" Tartus: T. Jonuks "Estonia in Old-Norse literature".

17.-20. aprillini SIEFi (The Societé Internationale d'Ethnologie et de Folklore) kongressil "People Make Places - Ways of Feeling the World" Lissabonis, Portugalis: M. Kõiva "Making the ritual space and place", M. Kõiva ja A. Kuperjanov "The Druzhe Tito Figure in YouTube", L. Vesik "Contemporary Estonian pupil dog lore".

20. aprillil Muinsuskaitseameti infopäeval Sõmerus: T. Jonuks "Miks arheoloogia?".

27. aprillil konverentsil "Noorte hääled" Tartus: K. Kikas "Jakob Hurda ja Matthias Johann Eiseni vastuolu kajastumine rahvaluulekogujate kirjades". 
30. aprillil pärimuskultuuri õppepäevadel Kuressaares: R. Kalle "Looduskeskkond ja pärimuskultuur. Taimepärimus" ja R. Sõukand "Ravimtaimede kasutuse muutus ajas".

26. mail Akadeemilise Rahvaluule Seltsi aastakoosolekul: P. Voolaid "Eesti mõistatused muutuvas kultuurikontekstis".

5. mail konverentsil "Sacred sites around the Baltic Sea" Ketrzyni muuseumis, Poolas: T. Jonuks "Isolated holy places - sites where nothing is around?".

10.-15. maini konverentsil "Taking Malta out of the Box: Island Cultures, Economies, and Identities" Vallettas, Maltal: M. Kõiva ja A. Kuperjanov "Signs of giants in the islands".

3. juunil pärimuskultuuri õppepäevadel Kuressaares: M. Kõiva "Rahvaarstid".

11. juunil Eesti Rahvusliku Folkloorinõukogu Koolituskeskuse ja Sangaste seltsimaja kursusel "Inimene ja loodus" Sangaste vallas Kunstimäe puhkemajas: R. Kalle "Rahvameditsiin, taimravi ja pärimus. Ravimtaimede tundmine. Ravimtaimede praktikum. Ravimtaimede korjamine".

12. juunil Kohtla valla päevade ajalookonverentsil: T. Jonuks "Kukruse kalme".

12. juunil Vikerraadio teadussaates andis R. Sõukand intervjuu platseebo olemusest (http://vikerraadio.err.ee/helid?main_ $\mathrm{id}=1585761$ ).

16. juunil Eesti Vabaharidusliidu Koolituskeskuse programmis "Täiskasvanute koolitus vabahariduslikes koolituskeskustes" Viljandimaal Energia talus: R. Kalle "Mis on pärandkooslused, pärandmaastikud, pärandkultuurmaastikud ja kuidas need on seotud taimedega".

3.-10. juulini IX etnoloogia ja antropoloogia kongressil Petroskois, Karjalas: M. Kõiva ja A. Kuperjanov "Медиум как резервуар знании”, L. Vesik “Валентин день”. 
5.-10. juulini ISHSi (International Society for Humor Studies) aastakonverentsil Bostonis, USAs: L. Laineste "Women in Estonian family jokes".

6. augustil konverentsil "Läänemere isandatest tänaseni - sõrulase tee muutuvas argipäevas" Salmel: E. Kalmre "Kirjandusmuuseumi töömailt: kogumisretked Sõrvemaale", avati ka tema koostatud näitus "Sõrvemaa paigad ja inimesed" (kujundanud Artur Kuus).

13. augustil astronoomiahuviliste XVI kokkutulekul Palal: M. Kõiva "Kuu folklooris".

15.-20. augustini rahvusvahelises huumori suvekoolis ja sümpoosionil Eesti Kirjandusmuuseumis: A. Krikmann "Relationships of punchlineless (and in general older) "Schwanks" and contemporary punchlined jokes ("Witzes")".

24.-26. augustini rahvusvahelisel interdistsiplinaarsel konverentsil "Imaging Spaces/Places" Helsingi Ülikoolis: K. Kikas "In the footsteps of Kalevipoeg. (Re)locating legendary places in Soviet Estonia”.

17.-26. septembrini SEACi (The European Society for Astronomy in Culture) 19. kongressil "Stars and Stones: Voyages in Archaeoastronomy and Cultural Astronomy - A meeting of different worlds" Evoras, Portugalis: M. Kõiva "Stones in Estonian mythology" ja A. Kuperjanov "About Karelian petroglyphs".

23. septembril üleeuroopalisel teadlaste ööl: R. Hiiemäe "Taevasest teenäitajast tarbimismaailma sõnumitoojaks: inglite kujutamisest reklaamis"; M. Kõiva ja A. Kuperjanov esinesid fotonäitusega "Surva".

3. oktoobril professor Vello Salo loengusarjas "Armastus eesti keeles, folklooris ja kirjanduses" Tartus: A. Krikmann "Armastus kui teema ja mõiste eesti jm vanasõnades ja mõnes muus folklooris".

6. oktoobril alusharidusõpetajate koolitusseminaril "A-B, hakka pähe! Mängust keeleni ja keelest mänguni” Tartu Ülikooli Narva 
Kolledžis: E. Kalmre "Laste hirmutamisest ja hirmujuttudest" ja P. Voolaid "Lasteaiapärimuse kogumisest uurimiseni - kogumisvõistlus 2011".

12.-16. oktoobrini Szegedi Ülikooli etnoloogia ja kultuuriantropoloogia osakonna korraldatud konverentsil "Heroes and Celebrities in Central and Eastern Europe": M. Kõiva "Lennu phenomenon".

12. oktoobril TÜ ajaloomuuseumis: T. Jonuks "Eesti usund muinas- ja keskaja piiril: olid nad kristlased või paganad?".

13.-17. oktoobrini Ida-Euroopa etnobioloogide teisel konverentsil Királyrétis, Ungaris: R. Kalle "Wild plants in Estonian food culture: outline of research sources", R. Sõukand "Personal and shared herbal landscapes".

20. oktoobril O. Lutsu nimelise raamatukogu krati-teemalisel muinasjutupäeval: K. Kikas "Kratist rahvaluuleteadlase vaatepunktist".

23. märtsil kevadise koolivaheaja loeng Tartu tähetornis: A. Kuperjanov "Jantar Mantar, Navagraha ja rauast sammas".

27.-30. oktoobrini ISFNRi töörühma "Committee on Charms, Charmers and Charming" peakomitee töökoosolekul ja konverentsil "Oral Charms in Structural and Comparative Light" Moskvas: M. Kõiva "Letters from heaven and manuscript incantation collections".

28. ja 29. oktoobril Poola-Eesti projektiseminaril "Creativity and Tradition in Polish and Estonian Cultural Communication" Krosnos, Poolas paarisettekanded: A. Lubecka ja L. Vesik (online) "National identities and display", D. Brzozowska ja A. Krikmann "Stereotypes in three-nation jokes", D. Brzozowska ja I. Ojam, L. Laineste "Gender stereotypes", W. Chłopicki ja L. Laineste, I. Piirimägi (online) "Stand-up comedy", M. Wojcicka ja E. Kalmre (online) "Urban legends", M. Iżykowska ja M. Kalda (online) "Money in culture", A. Lubecka ja M. Kõiva (online) "Ritual year", M. Poprawa ja M. Rebane "Political discourse as folklore", G. Szpila ja P. Voolaid "Graffiti, proverbs, riddles”, A. Teresz- 
kiewicz ja L. Laineste "Verbal Aggression on the Internet", T. Piekot ja A. Baran "Multimodal texts".

4. novembril Eesti Akadeemilise Usundiloo Seltsi aastakonverentsil "Vormelid ja tehnikad religioonis": M. Kõiva "Käsikirjalised nõiaraamatud".

6.-15. novembrini viiendal vanasõnade uurimise alasel teadusüritusel "Interdisciplinary Colloquium on Proverb" Taviras, Lõuna-Portugalis: A. Baran ja P. Voolaid "In graffiti veritas".

10.-14. novembril SIEFi töörühma “The Ritual Year” 7. konverentsil "Researchers, Performance, Researcher Co-Designing Heritage, Co-Designing Performance" Ljubljanas, Sloveenias: M. Kõiva ja A. Kuperjanov "Back to the first class. Rituals connected with finishing school".

15. novembril Ljubljana Ülikoolis sarjas "Euroopa mütoloogiad": M. Kõiva "Estonian folk prophets".

17. ja 18. novembril koolitusseminaril "A-B, hakka pähe! Kui ei hakka, lükkan takka!" Eesti Kirjandusmuuseumis ja Eesti Rahva Muuseumis: A. Õim "Kujundi roll emakeele omandamisel”, P. Voolaid "Ussa-pussa, ussa-maru, sina oled mängus karu! Lasteaiapärimuse kogumisvõistlus 2011", E. Kalmre "Hirmust, hirmutamisest ja hirmujuttudest", P. Voolaid ja A. Tuisk "Liisklugemised ja lõbusad riimid lastepärimuses".

25. ja 26. novembril Luxembourgi keelepäevadel: A. Õim "Metafoorid, mille järgi me elame", "Metafoorid keelearengus".

28. novembril 8. interdistsiplinaarsel konverentsil "Medica: Medical Pluralism in the Era of Digimodernism" Eesti Kirjandusmuuseumis: M. Kõiva "Constructive alternativism and the healers", R. Kalle ja R. Sõukand "Unintentional prevention of diseases: historical study on Estonian tea-plants".

28.-30. novembril Leedu Kultuuriuuringute Instituudi rahvusvahelisel konverentsil "Cultural Research in the 21st Century: Heritage, Identities and New Rhetoric" Vilniuses: E. Kalmre "About the folklore process: On the example of the Sõrve peninsula". 
29. ja 30. novembril Eesti rahvuseepose "Kalevipoeg" 150. aastapäevale pühendatud sümpoosionil "Traditional and Literary Epics of the World: Textuality, Authorship, Identity” Tartus: K. Kikas "Dr. Kreutzwald has been blamed... A village tailor H. A. Schults defending the authenticity of Kreutzwald's Kalevipoeg", M. Kõiva "Kalevipoeg as the basis of new narrative forms".

14.-16. detsembrini TAGi (The Theoretical Archaeology Group) konverentsil Birminghamis: T. Jonuks koos Ester Orase ja Kristiina Johansoniga "Terms and concepts in archaeology of religion".

15. detsembril osalesid M. Kõiva ja A. Kuperjanov Eesti-Bulgaaria kahepoolse projekti arutelul ja lõpparuande kinnitamisel Sofias (koostöö Bulgaaria TA Etnoloogia ja Folkloristika instituudi ja Etnograafia Muuseumiga).

21. ja 22. detsembril 55. Kreutzwaldi päevade teaduskonverentsil Eesti Kirjandusmuuseumis: R. Hiiemäe "Gnoomid, kooboldid ja goblinid. Uskumusolendite nimetuste tõlkimise spetsiifikast”, R. Sõukand ja R. Kalle "Tõlked ja valetõlked Eesti taimepärimuse mõjutajatena”, M. Kõiva "Mitmekeelsed loitsud. Kas tõlked või koodivahetus?".

\section{Siseseminaride ettekanded}

Folkloristide teisipäevaseminarid toimusid M. Kalda koordineerimisel, kokku toimus 19 seminari.

4. jaanuaril tutvustas N. Kuznetsov ühte osa äsja ilmunud raamatust “Зыряне и зырянски краи в литературных документах XIX века” (Sürjalased ja sürjamaa 19. sajandi kirjasõnas).

18. jaanuaril kõneles A. Kuperjanov astraaluskumustest (pikemalt Tunguusi meteoriidiga seonduvast).

25. jaanuaril tutvustas K. Kikas Paul van der Grijpi raamatut "Passion and Profit. Towards an Anthropology of Collecting" (2007).

1. veebruaril rääkis $M$. Kõiva käsikirjalistest nõia- ja maagiaraamatutest. 
8. veebruaril tutvustas Kadri Tüür esialgset failirepositooriumi.

15. veebruaril esines R. Hiiemäe: “Kommertsmaailma sõnumitoojad. Inglite kujutamine tarbijareklaamides".

8. märtsil andsid M. Kõiva, L. Vesik ja A. Kuperjanov ülevaate 22.25. veebruarini Kirde-Indias Shillongis toimunud Rahvusvahelise Rahvajutu-uurimise Seltsi (ISFNR) vahekonverentsist.

5. aprillil rääkis T. Jonuks looduslikest pühapaikadest ja üldsuse eest varjatud pühapaikadest.

14. aprillil (erandina neljapäeval) esines Sloveenia TA Etnoloogia Instituudi teadur Maja Godina Golija: "The potato in Slovenia: From hatred to glory".

19. aprillil rääkis Agnes Aljas tänapäeva argielu dokumenteerimisest ning viimaste aastate Eesti Rahva Muuseumi välitöödepraktikast ja vajadustest.

3. mail külastati seminari raames näitust "Kukruse kaunitar ja tema kaasaegsed: Eesti rikkalikem kalmistu muinas- ja keskaja piirilt”. Väljapanekut tutvustas üks näituse koostajaid T. Jonuks.

31. mail andsid Mari Sarv ja Kadri Tüür ülevaate konverentsist "Aligning National Approaches to Digital Preservation" rahvusraamatukogus.

13. septembril osakonna külalisuurija L. Granbom-Herraneni seminar "Vanasõnad SMSides - vanad sõnad, uus kontekst".

5. oktoobril oli tutvustas Aleksandra Arhipova vene folkloristika uusi jooni.

18. oktoobril pidas Ekaterina Tsirkova ettekande udmurdi loitsude kogumis- ja uurimisloost ning klassifitseerimisest.

22. novembril kõneles A. Baran fraseologismide visualiseerimisest.

28. novembril tutvustas Dmitri Funki (Moskva) Siberi väikerahvaste folklooritekstide elektroonilist korpust (šori, teleuudi ja evengi materjalid).

6. detsembril arutles R. Hiiemäe teemal "Vormelid ja narratiivid peomuljete jagamise saidi eileklubis.com materjalis". 
13. detsembril tutvustas N. Kuznetsov Anna-Leena Siikala ja Oleg Ulyashevi värsket raamatut "Hidden Rituals and Public Performances: Traditions and Belonging among the Post-Soviet Khanty, Komi and Udmurts" (2011), keskendudes komidest kõnelevale osale.

\section{Loengutsüklid}

Eesti Kunstiakadeemias: "Eesti folkloor” (M. Kõiva).

Tartu Ülikoolis: "Sissejuhatus soome-ugri keelte ja eesti keele uurimisse"; soome-ugri keelte seminar; ungari keele seminar; komi keel; soome-ugri keelte magistriseminar; ungari keele magistriseminar (N. Kuznetsov).

Eesti Maaülikoolis: 2011/2012 õppeaastal e-kursus "Sissejuhatus etnobotaanikasse” (Renata Sõukand, Raivo Kalle).

Eesti Usuteaduste Instituudis: “Eesti rahvausund” (M. Kõiva).

\section{Rahvusvaheline koostöö}

Eesti-Poola ühisprojekt "Creativity and tradition in Estonian and Polish cultural communication” (L. Laineste, W. Chlopicki).

Soome-Eesti ühisprojekt "Pohjois-Euroopan kansojen yhteisten sananlaskujen vertaileva tutkimus" (A. Krikmann).

Venemaa, Soome, Ungari ja Eesti ühisprojekt "Mythologia Uralica" (M. Kõiva).

EKMi ja Peterburi Kunstkamera projekt “Traditions and Innovations” (juhid J. Berezkin, M. Kõiva).

Eesti-Bulgaaria ühisprojekt "Folklore and Dynamics of Identities in New Europe - the case of Bulgaria and Estonia" (2009-2011) (juhid E. Anastasova, M. Kõiva, täitjad T. Ojamaa, K. Labi ja A. Kuperjanov).

“Uralic Mythologies” (M. Hoppál, M. Kõiva). 
"Widespread Idioms in Europe and Beyond. A Cross-linguistic and Crosscultural Research Project" (A. Baran).

Intercontinental Dialogue on Phraseology Project (IDP Projekt) "Research on Phraseology in Europe and Asia: Focal Issues in Phraseological Studies" (A. Baran).

Kokkuvõttes oli aasta 2011 töiselt keeruline ja pinges, täis uusi ideid ja osalt valmivaid, osalt jätkuna kulgevaid mahukaid töid ja laienevaid koostööprojekte. Aasta esimesse poolde jäi nelja doktoritöö edukas kaitsmine (P. Paal, A. Baran, M. Kalda, P. Voolaid). See annab palju arenguvõimalusi nii väitekirja kaitsnutele kui ka kogu osakonnale. Samas on tõsieluline tõik, et nüüdsest on peaaegu kõikidel osakonna teaduritel doktorikraad ja seda majanduskitsikuse laine haripunktis.

Valmis uudne lühivormide alussõnastik FES ja rida uurimusi, mis jäävad pikemaks ajaks püsima kui oma aja teadusmõtte maamärgid. Toimus märkimisväärseid üritusi, nagu osavõtjate kõrge tunnustuse pälvinud Rahvusvahelise Huumori Uurimise Seltsi suvekool ja sümpoosion L. Laineste juhtimisel. Ühe kirjastuse Mouton de Gruyter auhinna pälvis P. Voolaid. P. Voolaiu vedada oli lasteaiapärimuse kogumisaktsioon, mis tõi kaasa uudse ainestiku ja vastajaterühma kõrval kahasse haridusministeeriumi jm kultuuriasutustega koolitussarja alushariduse õpetajatele. Teadustöö kõrval on valminud mitmed laiale lugejaskonnale suunatud tellimusraamatud. Üritustest mainigem veel Eesti-Poola ühiskonverentsi oma uuendusliku paarisettekannete sarjadega ning Medica sarja 8. konverentsi "Medical Pluralism in the Era of Digimodernism" ja folkloristide talvekonverentsi, mis oli pühendatud serveri Haldjas 15. aastapäevale ning mis vahendas interneti-uuringuid, edusamme digi-andmebaaside alal ja nüüdiskultuuri uurimisel.

Suurepärased rahvusvahelised kontaktid on olnud Poola, Bulgaaria, Sloveenia ja Portugali suunal, laabunud on koostöö rahvusvaheliste formaalsete ja mitteformaalsete töörühmadega. 2011. aastal ilmus SIEFi töörühma "The Ritual Year" aastaraamat (M. Kõiva, Mall ja Gordon Leman), samuti P. Paali koostatud Põh- 
ja-Euroopa uurijaid haarav artiklivalimik "Inimene, tervis ja haigused" sarjas "Tänapäeva folkloorist”; jätkus erialaajakirjade Folklore: Electronic Journal of Folklore ja Mäetagused väljaandmine, millele lisandus ISFNRi töörühma ajakiri Incantatio. Kõige selle juures on oluline olnud kooskõla ja kõigi osakonna töötajate mõistev ning sõbralik koostöö parema tulemuse nimel, õla alla panemine, olgu selleks siis konverentsid, väljaanded, välitööd, digiteerimine, tehniline töö või analüüs suurprojektide heaks. 


\section{Eesti Kirjandusmuuseumi väljaanded 2011}

\section{Merike Kiipus}

\section{Trükised}

$11^{\text {th }}$ International summer shool for humour research : theory, research, applications : programme, lecture materials and symposium abstracts : $15^{\text {th }}-20$ August 2011, Tartu / editor Liisi Laineste ; assistant editor Maris Kuperjanov. Tartu : ELM Scholarly Press, 2011. $240 \mathrm{lk}$.

Eetika ja valikud : Akadeemilise Rahvaluule Seltsi kogumiskonverents Tartus, 27. oktoobril 2011 / Akadeemiline Rahvaluule Selts ; koostaja ja toimetaja Eda Kalmre. Tartu : EKM Teaduskirjastus, 2011. $22 \mathrm{lk}$.

Faehlmann, Friedrich Robert. Teosed. III / Eesti Kirjandusmuuseum ; Eesti TA Underi ja Tuglase Kirjanduskeskus ; koostanud Kristi Metste, Jaan Undusk, Marju Lepajõe. Tartu-Tallinn : Eesti Kirjandusmuuseum : Eesti TA Underi ja Tuglase Kirjanduskeskus, 2011. $455 \mathrm{lk}$.

Folklore : electronic journal of folklore : printed version / Folk Belief and Media Group of the Estonian Literary Museum ; Estonian Institute of Folklore ; edited by Mare Kõiva \& Andres Kuperjanov. Tartu : Folk Belief and Media Group of the Estonian Literary Museum.

Vol. 47. 2011. $208 \mathrm{lk}$.

Vol. 48. 2011. $216 \mathrm{lk}$.

Vol. 49. 2011. $160 \mathrm{lk}$. 
Haldjas 15: pärimus ja Internet : Eesti folkloristide 6. talvekonverents : teesid : 3.-4. veebruar 2011, Jõgeveste / EKM Teaduskirjastus ; Eesti Kirjandusmuuseumi folkloristika osakond ; koostajad: Helen Hanni, Maris Kuperjanov. Tartu : EKM Teaduskirjastus, 2011. $26 \mathrm{lk}$.

Inimene, tervis ja haigused : terviseteemaline artiklikogumik "Medica" / Eesti Kirjandusmuuseum ; koostanud Piret Paal ; toimetajad Eda Kalmre, Piret Paal. Tartu : EKM Teaduskirjastus, 2010. 337 lk. (Tänapäeva folkloorist ; 9) [ilmus 2011]

Kalender 2011; Kalender 2012 / Eesti Kirjandusmuuseum ; koostajad Vilve Asmer, Risto Järv, Merike Kiipus, Kadri Tüür. Tartu : Eesti Kirjandusmuuseum 2010. 24 lk. [ilmus 2011]

Nüpli I suvekool (18. kevadkool) : kaotatud klassika : lähilugemine : teesid : 26.-27. august 2011, Otepää vald / koostajad: Marin Laak, Johanna Ross. Tartu : Eesti Kirjandusmuuseum 2011. 36 lk.

Kuldkalake / toimetajad: Ave Tupits, Kanni Labi. Tartu : Eesti Kirjandusmuuseumi teaduskirjastus, 2011. $109 \mathrm{lk}$. (Pro folkloristica ; 16)

Luhtatulek : ekslemisi Mehis Heinsaare tihnikutes / Eesti Kirjandusmuuseumi kultuuri- ja kirjandusteooria töörühm ; koostaja Sven Vabar ; toimetaja Mari Laaniste. Tallinn ; Tartu : Tartu Ülikooli Kirjastus, 2011. 200 lk. (Etüüde nüüdiskultuurist ; 3)

Medica VIII : Medical pluralism in the era of digimodernism : [International Conference of Ethnomedicine and Medical Anthropology] : November 28, 2011, Tartu : abstracts \& schedule / Department of Folkloristics, Estonian Literary Museum ; Estonian Institute of Folklore ; editor Mare Kõiva. Tartu : EKM Teaduskirjastus, 2011. $15 \mathrm{lk}$.

Metsast leitud kirik = Mõtsast löütü kerik : Urvastõ kohapärimus / Eesti Kirjandusmuuseum ; koostanud Valdo Valper ; toimetaja Mall Hiiemäe. Tartu : EKM Teaduskirjastus, 2010. 149 lk. (Eesti Rahvaluule Arhiivi Toimetused ; 28) [ilmus 2011] 
Mäetagused : hüperajakiri / Eesti Kirjandusmuuseumi folkloristika osakonna rahvausundi ja meedia töörühm, MTÜ Eesti Folkloori Instituut ; toimetajad: Mare Kõiva, Andres Kuperjanov ; tegevtoimetaja Asta Niinemets. Tartu : EKM Teaduskirjastus.

Nr. 47. 2011. $184 \mathrm{lk}$.

Nr. 48. 2011. $160 \mathrm{lk}$.

Nr. 49. 2011. 208 lk.

Ojamaa, Triinu. 60 aastat eesti koorilaulu multikultuurses Torontos $=60$ years of Estonian choral singing in multicultural Toronto / toimetaja: Kanni Labi ; tõlkija: Mall Puhm. Tartu : Eesti Kirjandusmuuseumi Teaduskirjastus, 2011. $398 \mathrm{lk}$.

Tõlge kultuuris : 55 . Kreutzwaldi päevade teadusliku konverentsi teesid : 21.-22. detsember 2011, Tartu / Eesti Kirjandusmuuseum : EKM teaduskirjastus ; toimetaja Mall Hiiemäe. Tartu : EKM Teaduskirjastus. $27 \mathrm{lk}$.

\section{Dissertatsioonid}

Baran, Anneli. Fraseologismide semantika uurimisvõimalused / juhendaja: Arvo Krikmann ; Tartu Ülikool, kultuuriteaduste ja kunstide instituut. Tartu : Tartu Ülikooli Kirjastus, c2011. 172 lk. (Dissertationes folkloristicae Universitatis Tartuensis ; 14) http://hdl.handle.net/10062/16515

Kalda, Mare. Rahvajutud peidetud varandustest: tegude saamine lugudeks / juhendaja: Jürgen Beyer ; Tartu Ülikool, kultuuriteaduste ja kunstide instituut. Tartu : Tartu Ülikooli Kirjastus, c2011. 273 lk. (Dissertationes folkloristicae Universitatis Tartuensis ; 15) - http://hdl.handle.net/10062/17237

Kalkun, Andreas. Seto laul eesti folkloristika ajaloos : lisandusi representatsiooniloole / juhendaja: Kristin Kuutma ; Tartu Ülikool, Kultuuriteaduste ja kunstide instituut. Tartu : Tartu Ülikooli Kirjastus, c2011. 284 lk. (Dissertationes folkloristicae Universitatis Tartuensis ; 18) - http://hdl.handle.net/10062/18222 
Näripea, Eva. Estonian cinescapes: spaces, places and sites in Soviet Estonian cinema (and beyond) : doctoral thesis = Eesti filmimaastikud. Ruumid, kohad ja paigad Nõukogude Eesti filmis (ning edaspidi). Tallinn : Eesti Kunstiakadeemia, 2011. 283 lk. (Dissertationes Academiae Artium Estoniae ; 6)

Voolaid, Piret. Eesti mõistatused kui pärimusliik muutuvas kultuurikontekstis / juhendajad: Arvo Krikmann, Tiiu Jaago ; Tartu Ülikool, kultuuriteaduste ja kunstide instituut. Tartu : Tartu Ülikooli Kirjastus, c2011. 239 lk. (Dissertationes folkloristicae Universitatis Tartuensis ; 16) - http://hdl.handle.net/10062/17528

\section{Koostööväljaanded}

Call it a day : contemporary comics from Finland, Estonia, Hungary and Latvia : FINEST 2010-2011 / editor: Mari Laaniste ; design: Joonas Sildre ; cover image: Dániel Csordás. Tallinn : Soome Instituut, 2011. $128 \mathrm{lk}$.

Hiiemäe, Mall. Pühad kivid Eestimaal / Eesti Kirjandusmuuseum, Eesti Rahvaluule Arhiiv ; koostanud Mall Hiiemäe ; toimetanud Tiina Tammer. Tallinn : Tammerraamat, 2011. $152 \mathrm{lk}$.

Incantatio : an international journal on charms, charmers and charming / ISFNR Committee on on Charms, Charmers and Charming, Estonian Literary Museum ; general editor Mare Kõiva. Tartu : ISFNR Committee on on Charms, Charmers and Charming.

Issue 1 / guest editor Jonathan Roper. 2011. $110 \mathrm{lk}$.

International symposium "Traditsional and literary epics of the world : textuality, autorship, identity : the Kalevipoeg 150" abstracts : Tartu, November 29-30, 2011 / Estonian Literary Museum ; Institute for Cultural Research and Fine Arts ; Tartu University; editor Pihla Siim. Tartu : ELM Scholarly Press, 2011. $44 \mathrm{lk}$.

Journal of Ethnology and Folkloristics : [the joint publication of the Estonian Literary Museum, the Estonian National Museum 
and the University of Tartu] / editor-in-chief Ergo-Hart Västrik ; managing editor Toivo Sikka ; editors: Terje Anepaio, Risto Järv, Art Leete, Aado Lintrop, Pille Runnel, Ülo Valk. Tartu : Estonian National Museum.

Vol. 4, No. 1. 2010. 93 lk. [ilmus 2011]

Vol. 4, No. 2. 2010. 136 lk. [ilmus 2011]

Vol. 5, No. 1. 2011. $125 \mathrm{lk}$.

Kalevipoeg : the Estonian national epic $=$ eesti rahvuseepos $/ \mathrm{F}$. R. Kreutzwald ; translator Triinu Kartus ; editor-in-chief and foreword: Marin Laak, editor of the translation Harri Mürk ; commentaries: David E. Gay ; artistic vision: Gunnar Neeme. Tartu : Eesti Kirjandusmuuseum ; Tallinn : Kunst, 2011. Eestikeelne tekst: 20. tr. $535 \mathrm{lk}$.

Komistusi metafooridega / koostanud Asta Õim ; toimetanud Katre Õim ; Tartu Ülikool. Tartu : Keelehooldekeskus, 2011. 58 lk. (Keelehooldekeskus ; 6)

Kunstiteaduslikke uurimusi $=$ Studies on art and architecture $=$ Studien für Kunstwissenschaft. $20: 3-4$ : Eesti filmi sajand $=$ Special Issue A Century of Estonian Cinema / Eesti Kunstiteadlaste Ühing = Estonian Society of Art Historians ; peatoimetaja: Virve Sarapik ; erinumbri toimetaja Eva Näripea. Tallinn : Eesti Kunstiteadlaste Ühing, 2011. $228 \mathrm{lk}$.

Kõiva, Mare. Eesti loitsud / toimetanud Veronika Kivisilla. Tallinn : Pegasus, 2011. 288 lk.

L'Esprit de la forêt : contes estoniens et seto / traduit de l'estonien par Eva Toulouze ; sélectionnés et commentés par Risto Järv. Genève : José Corti, 2011. 257 lk.

Lintrop, Aado. Õhtud sõidavad õue / toimetanud Siiri Ombler. Tartu : Ilmamaa, 2011. $136 \mathrm{lk}$.

Methis : studia humaniora Estonica. 7 / TÜ kultuuriteaduste ja kunstide instituut, Eesti Kirjandusmuuseumi kultuurilooline arhiiv ; koostajad Sirje Olesk ja Tiina Saluvere. Tartu : Eesti Kir- 
jandusmuuseum ; Tartu Ülikooli kultuuriteaduste ja kunstide instituut, 2011. $270 \mathrm{lk}$.

Nr. 7 (kevad). Nõukogude aja erinumber / koostajad Sirje Olesk ja Tiina Saluvere. $270 \mathrm{lk}$.

Nr. 8. Vabanumber / koostajad Jaak Tomberg, Marin Laak. 213 lk.

Noorte hääled : noorte etnoloogide ja folkloristide konverents : Tartu, 27.-28. aprill 2011 : ettekannete kokkuvõtted / koostajad Marleen Nõmmela, Ave Tupits. Tartu : Eesti Rahva Muuseum, 2011. $35 \mathrm{lk}$.

Remmel, Mari-Ann. Päritud paigad : kohajutte ja legende Rae vallast / Rae Vallavalitsus ; Eesti Kirjandusmuuseum, Eesti Rahvaluule Arhiiv ; toimetamine: Kadri Tamm, Heiki Valk, Valdo Valper. Jüri, Tartu : Eesti Kirjandusmuuseum, 2011. 160 lk.

Stam, Robert. Filmiteooria : sissejuhatus / tõlkijad: Eva Näripea, Mari Laaniste, Andreas Trossek ; toimetajad: Eva Näripea, Mari Laaniste. Tallinn : Eesti Kunstiakadeemia, 2011. 399 lk.

Sõjas kasvanud poisid : Eesti meeste mälestused sõjast ja Saksa okupatsioonist / Eesti Kirjadusmuuseum, Ühendus Eesti Elulood ; koostanud Rutt Hinrikus ; toimetanud Livia Viitol. Tallinn : Tänapäev, c2011. $277 \mathrm{lk}$.

The Ritual Year. 6, The inner and the outer : the yearbook of the SIEF Working Group on the Ritual Year : peer reviewed articles based on the Presentations of the Conference in Tallinn, Estonia 4-7 June, 2010 / SIEF Working Group on the Ritual Year ; ELM Department of Folkloristics ; edited by Mare Kõiva. Tartu : ELM Scholarly Press, 2011. 399 p.

Tomberg, Jaak. Kirjanduse lepitav otstarve / toimetanud Neeme Lopp. Tartu : Tartu Ülikooli Kirjastus, 2011. 199 lk. (Heuremata : humanitaarteaduslikke monograafiaid)

Trajectories of (Be)longing : Europe in Life Writing. IABA Europe 2011, May 18-20, Tallinn University, Estonia : abstracts / Estonian Institute of Humanities, Tallinn University ; Estonian Lit- 
erary Museum ; compiled by Leena Kurvet-Käosaar. Tartu : Eesti Kirjandusmuuseumi Teaduskirjastus, 2011. 108 lk.

Tüdruk veiniplekiga kleidis : tänapäeva hirmu- ja õudusjutte / koostanud Eda Kalmre ; toimetaja Anu Jõesaar. Tallinn : Ajakirjade Kirjastus, 2011. $112 \mathrm{lk}$.

Uku Masing. Aarded tellistes / koostanud ja toimetanud Mari-Liis Tammiste, Risto Järv, Kristi Salve. Tartu : Ilmamaa, 2011. 328 lk.

Uurimusi 1940. aastate eesti kirjandusest / Tallinna Ülikool, eesti keele ja kultuuri instituudi kirjandusteaduse osakond ; koostanud Anneli Kõvamees ja Piret Viires ; toimetanud Anneli Kõvamees ; eessõna: Sirje Olesk, Piret Viires. Tallinn : Eesti Keele Sihtasutus, 2011. $183 \mathrm{lk}$.

Voolaid, Piret. Elu on lill, ainult kasta! : kõnekäände inimesest ja elamisest. Tallinn : Ajakirjade Kirjastus, 2011. $100 \mathrm{lk}$.

\section{E-väljaanded}

Eesti fraseologismide elektrooniline alussõnastik / koostanud Asta Õim, Katre Õim. Tartu : Eesti Kirjandusmuuseum, 2011 - http:// www.folklore.ee/justkui/sonastik

Eetika ja valikud : Akadeemilise Rahvaluule Seltsi kogumiskonverents Tartus, 27. oktoobril 2011 / Akadeemiline Rahvaluule Selts ; koostaja ja toimetaja Eda Kalmre. Tartu : EKM Teaduskirjastus - http://www.folklore.ee/rl/inste/ars/kk11/teesid.htm

Folklore : electronic journal of folklore / Folk Belief and Media Group of the Estonian Literary Museum ; edited by Mare Kõiva \& Andres Kuperjanov. Tartu : Estonian Literary Museum, 2010. Vol. 47 - http://www.folklore.ee/folklore/vol47/

Vol. 48 - http://www.folklore.ee/folklore/vol48/

Vol. 49 - http://www.folklore.ee/folklore/vol49/

Haldjas 15: pärimus ja Internet : Eesti folkloristide 6. talvekonverents : teesid : 3.-4. veebruar 2011, Jõgeveste / EKM Teaduskirjas- 
tus ; Eesti Kirjandusmuuseumi folkloristika osakond ; koostajad Helen Hanni, Maris Kuperjanov. Tartu : EKM Teaduskirjastus, 2011 - http://www.folklore.ee/rl/fo/konve/2011/ftk6/teesid.pdf

Incantatio : an international journal on charms, charmers and charming / ISFNR Committee on on Charms, Charmers and Charming, Estonian Literary Museum ; general editor Mare Kõiva. Tartu : ISFNR Committee on on Charms, Charmers and Charming.

Issue 1 / guest editor Jonathan Roper. 2011 - http://www.folklore.ee/incantatio/01.html

International symposium "Traditsional and literary epics of the world : textuality, autorship, identity : the Kalevipoeg 150" : abstracts : Tartu, November 29-30, 2011 / Estonian Literary Museum ; Institute for Cultural Research and Fine Arts ; Tartu University; editor Pihla Siim. Tartu : ELM Scholarly Press http://www.folklore.ee/events/epics2011/abstracts.pdf

Journal of Ethnology and Folkloristics : [the joint publication of the Estonian Literary Museum, the Estonian National Museum and the University of Tartu] / editor-in-chief Ergo-Hart Västrik; managing editor Toivo Sikka ; editors: Terje Anepaio, Risto Järv, Art Leete, Aado Lintrop, Pille Runnel, Ülo Valk. Tartu : Estonian National Museum.

Vol. 4, No. 1-2; Vol. 5, No. 1 - http://www.jef.ee/

Medica VIII : Medical pluralism in the era of digimodernism : [International Conference of Ethnomedicine and Medical Anthropology] : November 28, 2011, Tartu : abstracts \& schedule / Department of Folkloristics, Estonian Literary Museum ; Estonian Institute of Folklore ; editor Mare Kõiva. Tartu : EKM Teaduskirjastus, 2011 - http://www.folklore.ee/rl/fo/konve/ medicaVIII/tees.pdf

Metsast leitud kirik = Mõtsast löütü kerik : Urvastõ kohapärimus / Eesti Kirjandusmuuseum ; koostanud Valdo Valper ; toimetaja Mall Hiiemäe. Tartu : EKM Teaduskirjastus, 2010 - http://www. folklore.ee/era/pub/files/ERAT28valik.pdf 
Mäetagused : hüperajakiri / Eesti Kirjandusmuuseumi folkloristika osakonna rahvausundi ja meedia rühm, MTÜ Eesti Folkloori Instituut ; toimetajad Mare Kõiva, Andres Kuperjanov. Tartu : EKM Teaduskirjastus, 2010.

Nr. 47 - http://www.folklore.ee/tagused/nr47/

Nr. 48 - http://www.folklore.ee/tagused/nr48/

Nr. 49 - http://www.folklore.ee/tagused/nr49/

Pühakud ja vägimehed : muinasjutte Lutsi maarahvalt ja nende naabritelt / Eesti Kirjandusmuuseumi Eesti Rahvaluule Arhiiv; Tartu Ülikooli eesti ja võrdleva rahvaluule osakond ; koostanud ja toimetanud Inge Annom, Risto Järv, Mairi Kaasik, Kärri Toomeos-Orglaan. Tartu : Eesti Kirjandusmuuseum, 2011 - http:// www.folklore.ee/muinasjutt/lutsi/

Sõjas kasvanud poisid: Eesti meeste mälestused sõjast ja Saksa okupatsioonist / Eesti Kirjadusmuuseum, Ühendus Eesti Elulood ; koostanud Rutt Hinrikus. Tallinn : Eesti Pimedate Raamatukogu, 2011. 1 CD (14 t. 53 min.). 